\begin{abstract}
UNIVERSIDADE DE SÃO PAULO
FACULDADE DE FILOSOFIA, LETRAS E CIÊNCIAS HUMANAS

DEPARTAMENTO DE LETRAS CLÁSSICAS E VERNÁCULAS

PROGRAMA DE PÓS-GRADUAÇÃO EM LITERATURA BRASILEIRA
\end{abstract}

ANA CAROLINA SÁ TELES

QUESTÃO MORAL E CONSTITUIÇÃO DO SUJEITO EM CONTOS DE MACHADO DE ASSIS

(Versão corrigida)

SÃO PAULO 
ANA CAROLINA SÁ TELES

\section{QUESTÃO MORAL E CONSTITUIÇÃO DO SUJEITO EM CONTOS DE MACHADO DE ASSIS \\ (Versão corrigida)}

Dissertação apresentada ao Programa de Pós-Graduação em Literatura Brasileira do Departamento de Letras Clássicas e Vernáculas da Faculdade de Filosofia, Letras e Ciências Humanas da Universidade de São Paulo, para obtenção do título de Mestre em Letras.

Orientador: Prof. Dr. Hélio de Seixas Guimarães

Versão corrigida. Resolução CoPRG, de 20 de dezembro de 2010. A versão original encontra-se disponível na FFLCH.

São Paulo 
Ana Carolina Sá Teles

Questão moral e constituição do sujeito em contos de Machado de Assis

Dissertação apresentada à Faculdade de Filosofia, Letras e Ciências Humanas da Universidade de São Paulo para obtenção do título de Mestre em Letras.

Aprovada em 12 de novembro de 2013.

Banca Examinadora

Profa. Dra. Cleusa Rios P. Passos

Julgamento: aprovada

Prof. Dr. Pedro Meira Monteira

Julgamento: aprovada

Prof. Dr. Hélio de Seixas Guimarães

(orientador)

Julgamento: aprovada
Instituição: FFLCH-USP

Assinatura:

Instituição: Princeton University

Assinatura:

Instituição: FFLCH-USP

Assinatura: 
Para minha mãe. 


\section{AGRADECIMENTOS}

Ao Prof. Dr. Hélio de Seixas Guimarães pela generosidade, orientação, seriedade, abertura ao diálogo e acolhida do Projeto.

À FAPESP pela concessão de Bolsa de Mestrado que possibilitou dedicação exclusiva à Pesquisa e recursos para seu desenvolvimento.

Ao Prof. Dr. Hélio de Seixas Guimarães, à Profa. Dra. Yudith Rosenbaum, ao Prof. Dr. José Antonio Pasta Jr. e ao Prof. Dr. José Luiz Passos pelas disciplinas de Pós-Graduação na área de Literatura Brasileira.

À Profa. Dra. Cleusa Rios P. Passos e ao Prof. Dr. Erwin Torralbo Gimenez pela valiosa participação no Exame de Qualificação.

Novamente à Profa. Dra. Cleusa Rios P. Passos e ao Prof. Dr. Pedro Meiro Monteira pela generosa participação na Banca de Defesa.

Ao Prof. Dr. Hélio de Seixas Guimarães, à Profa. Dra. Cleusa Rios P. Passos e ao Prof. Dr. José Miguel Wisnik por terem fornecido textos relevantes e inacessíveis.

Aos funcionários da Secretaria de Pós-Graduação do DLCV e do PAE-USP.

Aos amigos do Grupo de Pesquisa "A recepção crítica de Machado de Assis" (CNPq) pelos debates sobre a obra machadiana.

Aos amigos de Letras e de Humanidades que compartilharam experiências no Mestrado: Adriana Batista, André Sanchez, Amanda Polato, Camila Rodrigues, Carla Santana, Carolina Serra Azul, Caroline Freitas, Cida Lamas, Cleide Rizério Silva, Emiliano Augusto, Igor Pantoja, Ivair Castelan, Joelma Ferreira, Juliana Muscovick, Leandro Villarino, Luana Smeets, Lucas Grosso, Maged El Gebaly, Maura Voltarelli, Patrícia Oliveira, Raquel Parrine, Samira Orra, Vicente Castro, Vivian Oliveira e Zaine Tavares.

À Ana Carolina.

À minha querida família, primeiros espelhos, pelo apoio. Ao meu amado namorado pelo apoio, igualmente. À sua também querida família pelo diálogo sobre o trabalho. 
"ela, porém, explicou de si mesma a diferença, [...]". Machado de Assis

«On est quelque foi aussi différent de soi-même que des autres». La Rochefoucauld 


\section{RESUMO}

TELES, Ana Carolina Sá. Questão moral e constituição do sujeito em contos de Machado de Assis. 2013. 175 f. Dissertação (Mestrado) - Faculdade de Filosofia, Letras e Ciências Humanas da Universidade de São Paulo, São Paulo, 2013.

Esta dissertação aborda a questão moral e questões relativas à constituição do sujeito em contos de Machado de Assis. Os contos analisados pertencem às décadas de 1870 e 1880. Os títulos são: "Ponto de vista (Quem desdenha...)", de Histórias da meia-noite; "O sainete"; "D. Benedita (Um retrato)", de Papéis avulsos; "Galeria Póstuma", "Uma senhora", de Histórias sem data; e "O enfermeiro", de Várias Histórias. Em vários dos contos, os protagonistas são confrontados por impasses de identidade, impasses de subjetivação ou ainda por dilemas morais, que acarretam em diferença subjetiva. Em adição, o narrador propõe dilemas estéticos e éticos que indagam o leitor, no gesto de leitura e interpretação. Desde Ressurreição, romance de 1872, Machado de Assis operara um deslocamento do foco da narração de costumes para o enfoque do "contraste entre dois caracteres". Também em artigo de 1878 sobre O Primo Basílio Machado havia levantado uma grande polêmica, que fez parte do que Roberto Schwarz nomeou, por exemplo, como "militância antirealista" do autor. No artigo a O Primo Basílio, Machado declarou a preferência pelos "caracteres", pelas "paixões" e pela "verdade moral" na composição do drama. Já no século 20, uma corrente crítica inaugurada na década de 1930, em especial, por Augusto Meyer e Lúcia Miguel Pereira, interpretou Machado de Assis pelo viés do "subterrâneo". Eles abriram caminho para uma crítica machadiana que considerasse, por exemplo, a psicanálise como interface na recepção literária. Lembremos, contudo, que Augusto Meyer era também tributário de Alcides Maya e responsável pelo esclarecimento de vínculos entre a ficção machadiana e a tradição de escritores moralistas. Nesse sentido, no século 20, não apenas a crítica machadiana psicológica ganhou espaço, como também a crítica que enfocou a questão moral. Entre os críticos machadianos que investigaram a questão moral, encontramos, por exemplo, o próprio Augusto Meyer, Alfredo Bosi, Ivan Teixeira, José Luiz Passos e Pedro Meira Monteiro.

Palavras-chave: Machado de Assis; conto; questão moral; constituição do sujeito. 


\begin{abstract}
TELES, Ana Carolina Sá. Morality and subject constitution in Machado de Assis's short stories. 2013. 175 f. Dissertação (Mestrado) - Faculdade de Filosofia, Letras e Ciências Humanas da Universidade de São Paulo, São Paulo, 2013.

This dissertation approaches morality and subject constitution in Machado de Assis's short stories. The analyzed short stories go back to the period of the 1870 s and 1880s. The titles are the following: "Ponto de vista (Quem desdenha...)" in Histórias da meia-noite; "O sainete"; "D. Benedita (Um retrato)" in Papéis avulsos; "Galeria Póstuma" and "Uma senhora" in Histórias sem data; and "O enfermeiro" in Várias histórias. In these short stories, the main characters are usually confronted with impasses concerning either identity, subjectivity or moral dilemmas that imply in subjective difference. In addition, the narrators propose esthetic and ethic dilemmas that question the reader in the act of reading and interpreting. In Ressurreição, novel of 1872, Machado had already dislocated the focus on narrating customs and had given priority to a plot centered on the contrast between two characters. In the article of 1878 on O primo Basílio, Machado started a huge controversy as well. This text takes part in what Roberto Schwarz names as Machado's "anti-Realism" militancy. In the article about $O$ primo Basilio Machado states the preference for the "art of the characters", "passions" and "morality" as main components in the drama. In the $20^{\text {th }}$ century, a new area of Machado's criticism emerged by approaching his works according to an "underground" tone (the word refers to Dostoevsky's book). This type of criticism was founded by Augusto Meyer and Lucia Miguel Pereira. They have opened the way for a criticism of Machado's works that can take into account a psychoanalytic interface in literature reception. Still, we should remember that Augusto Meyer referred to Alcides Maya and was responsible for pointing out the connections between Machado de Assis and the moralist writers. Thus, there has been an overture not only to psychological criticism but also to the criticism concerned with morality in Machado's works. Among exponent critics who have investigated morality in Machado, we can mention Augusto Meyer, Alfredo Bosi, Ivan Teixeira, José Luiz Passos and Pedro Meira Monteiro.
\end{abstract}

Keywords: Machado de Assis; short story; morality; subject constitution. 


\section{SUMÁRIO}

PARTE I

1. Introdução

1.1 Questão moral no artigo sobre O primo Basílio...................................10

$1.2 \mathrm{Da}$ técnica do caráter à personagem como pessoa.............................22

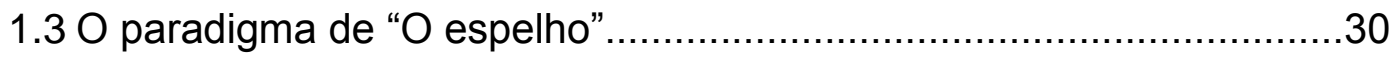

PARTE II

1. Dois contos da década de 1870: "Ponto de vista (Quem desdenha...)" (1873)

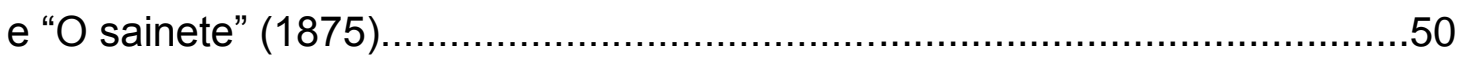

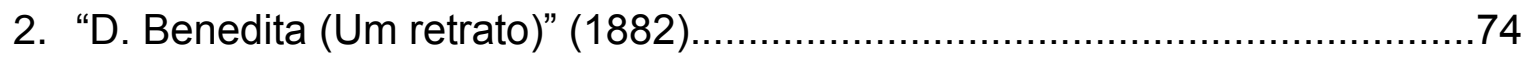

3. "Galeria Póstuma" (1883) ......................................................................111

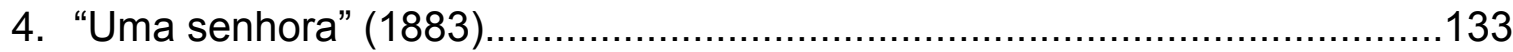

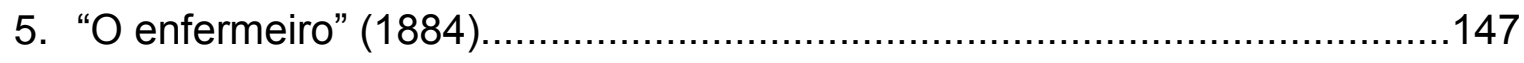

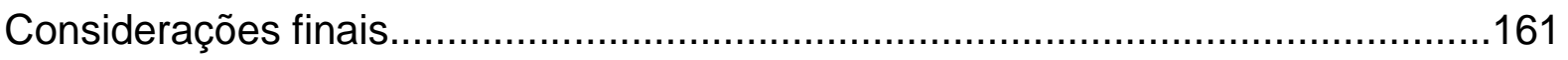

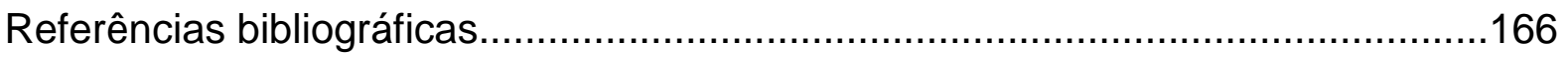




\section{PARTE I}




\section{Introdução}

\section{1. "Questão moral” no artigo sobre O primo Basílio}

Este trabalho investiga a questão moral em contos de Machado de Assis e suas implicações na concepção de sujeito na obra machadiana que pode ser depreendida, por exemplo, a partir da composição de personagens complexos. A questão moral e as questões de subjetividade serão abordadas não apenas na composição dos personagens, mas também como tema nas narrativas.

Dessa forma, os seguintes contos são analisados: "Ponto de vista (Quem desdenha...)" (1873), de Histórias da meia-noite, e "O sainete" (1875), conto avulso da década de 70; "D. Benedita" (1882), de Papéis avulsos; "Galeria póstuma” (1883) e "Uma senhora" (1883), de Histórias sem data; e "O enfermeiro" (1884), de Várias histórias. O objetivo é analisar essas obras curtas, segundo uma orientação cronológica, para pensar a questão moral e noções de constituição do sujeito em Machado de Assis.

A escolha desses contos justifica-se por neles haver atenção sobre episódios que colocam em debate a "pessoa moral" dos protagonistas, ou pelo fato de neles depararmo-nos com personagens que apresentam aspectos de subjetividade descentrada, ou ainda porque questões de constituição do sujeito estão implicadas como tema nas obras.

Comecemos, portanto, pelo delineamento do que se pode chamar de questão moral em Machado de Assis, partindo de obras do próprio autor. Para tanto, retomarei os seguintes textos críticos de Machado, que abordam a questão moral enquanto componente de poética literária: a "Advertência" a Ressurreição, de 1872; a crítica "Notícia da atual literatura brasileira - Instinto de Nacionalidade", de 1873; e, principalmente, o artigo "Literatura realista (O primo Basílio, romance do Sr. Eça de Queirós, Porto, 1878)".

Em 1872 Machado de Assis publicou seu primeiro romance, Ressurreição, frequentemente referido como espécie de "gérmen" do cronológica e qualitativamente longínquo Dom Casmurro. Excêntrico em relação às expectativas da produção literária do período, Ressurreição foi compreendido como pouco imaginativo, além de criticado segundo critérios românticos então hegemônicos. Ao demolir conceitos românticos nessa obra, contudo, Machado de Assis fez referência 
a eles, justamente como se os implodisse, ou seja, suscitando-os para fazê-los ruir "a partir de dentro", conforme analisou Hélio de Seixas Guimarães (2004, p. 126) ${ }^{1}$.

Se pensarmos que um dos legados de algumas vertentes do romantismo foi a retomada de Shakespeare e a defesa de seus princípios estéticos "orgânicos" ou "misturados" por contraposição à poética clássica, podemos perceber já no prólogo de Ressurreição o momento em que o autor dialoga com um paradigma de fundo romântico, mas de forma diversa. Assim, Shakespeare é referido por Machado de Assis em relação ao núcleo do seu romance na "Advertência da Primeira Edição", em que são colocados em primeiro plano a "situação" e "os caracteres":

Minha ideia ao escrever este livro foi pôr em ação aquele pensamento de Shakespeare:

Our doubts are traitors

And make us lose the good we oft might win,

By fearing to attempt.

Não quis fazer romance de costumes, tentei o esboço de uma situação e o contraste de dois caracteres; com esses simples elementos busquei o interesse do livro (ASSIS, 2008, p. 236).

Portanto, Machado cita Shakespeare com o propósito de evocar a dúvida subjetiva e o contraste dos caracteres como questões centrais do romance. Aliás, em função do rigor na composição da ação e do protagonista Félix, personagem soturno, as implicações do romance passam igualmente pelo malogro de clichês de cunho romântico muito em voga para o público brasileiro de literatura de então.

Ainda segundo Guimarães (2004, p. 126-130), as expectativas dos personagens em Ressurreição são levantadas e frustradas de forma conjunta às expectativas do leitor padrão do contexto de Machado. Ou melhor, as expectativas no romance são suscitadas justamente para serem frustradas junto com o paradigma romântico "imaginoso". Essa é a situação esboçada por Machado e decorre em grande parte da infrutífera "pessoa moral" de Félix, personagem em que a imaginação, longe de ser desejável, dá ensejo à desconfiança e ao ciúme.

Lúcia Miguel Pereira afirma que Ressurreição apresenta enquanto obra de estreia no gênero a principal característica de Machado de Assis como romancista

\footnotetext{
${ }^{1}$ Cito excerto sobre os romances de estreia Ressurreição e $A$ mão e a luva: "Em comum, temos narradores que lançam mão dos esquemas e preceitos dominantes para demonstrar sua artificialidade e impropriedade, minando alguns procedimentos do romantismo desde dentro e procurando transformar o leitor, se não num anti-romântico, pelo menos num receptor crítico da literatura romântica" (GUIMARÃES, 2004, p. 126).
} 
que seria a "predominância dos problemas psicológicos" (PEREIRA, 2004, p. 141). Apesar de não louvar o livro em razão de sua "execução falha", a crítica o valoriza na medida em que reconhece nele o ponto de partida nos romances de Machado de uma peculiar "redução do drama aos conflitos morais", à "índole" e à "situação das personagens". Pereira chega a defender que essa seria uma constante do autor, desde o romance de 1872 até o Memorial de Aires (PEREIRA, 2004, p. 141).

Ao pensarmos em Ressurreição, cuja composição demonstra princípios que ecoariam posteriormente na crítica escrita por Machado de Assis, em especial, "Notícia da atual literatura brasileira - Instinto de Nacionalidade" (1873) e "Literatura realista (O primo Basílio, romance do Sr. Eça de Queirós, Porto, 1878)", entramos num circuito da obra de Machado que passa pela "questão moral".

No ensaio "Notícia da atual literatura brasileira - Instinto de Nacionalidade", por exemplo, vemos a crítica de Machado recair, por um lado, sobre a ênfase na "cor local" e sobre as incorreções da língua (que o escritor considera defeitos) e, por outro, sobre a "observação", a "análise" e o "sentimento" como "dotes" de qualidade da literatura nacional. Desde o ensaio de 1873, percebe-se a defesa de Machado de Assis em relação ao desenvolvimento das "paixões" e dos "caracteres":

Pelo que respeita à análise de paixões e caracteres são muito menos comuns os exemplos que podem satisfazer à crítica; alguns há, porém, de merecimento incontestável. Esta é, na verdade, uma das partes mais difíceis do romance, e ao mesmo tempo das mais superiores. Naturalmente exige da parte do escritor dotes não vulgares de observação, que, ainda em literaturas mais adiantadas não andam a rodo nem são a partilha do maior número.

As tendências morais do romance brasileiro são geralmente boas. Nem todos eles serão de princípio a fim irrepreensíveis; alguma coisa haverá que uma crítica austera poderia apontar e corrigir. Mas o tom geral é bom. Os livros de certa escola francesa, ainda que muito lidos entre nós, não contaminaram a literatura brasileira, nem sinto nela tendências para adotar suas doutrinas, o que é já notável mérito (ASSIS, 2008, p. 1207 [grifo meu]).

A escola francesa mencionada é o realismo (o que inclui a radicalização naturalista). Na crítica a $O$ primo Basílio, de 1878, os ataques de Machado aos princípios da escola seriam feitos de forma rigorosa. Abordando em detalhe 0 romance de Eça de Queirós, Machado aponta falhas na composição da obra, mencionando também O Crime do Padre Amaro, mas expressando suas reservas em relação ao movimento como um todo. 
$\mathrm{Na}$ introdução da crítica, o comentário de Machado recai sobre O crime do Padre Amaro, assinalando a incoerência da trama. O que o escritor brasileiro não compreende é o porquê do assassinato do filho do padre num meio social que é conivente com os desvios em relação à norma eclesiástica:

O próprio O crime do Padre Amaro é imitação do romance de Zola, La faute de l'abbé Mouret. Situação análoga, iguais tendências; diferença do meio; diferença do desenlace; idêntico estilo [...]. Quem os leu a ambos, não contestou decerto a originalidade do Sr. Eça de Queirós, porque ele tinha, e tem, e a manifesta de modo afirmativo; creio até que essa mesma originalidade deu motivo ao maior defeito de concepção d'O crime do padre Amaro. O Sr. Eça de Queirós alterou naturalmente as circunstâncias que rodeavam o Padre Mouret, administrador espiritual de uma paróquia rústica, flanqueado de um padre austero e ríspido; o padre Amaro vive numa cidade de província, no meio de mulheres, ao lado de outros que do sacerdócio só têm a batina e as propinas; vê-os concupiscentes e maritalmente estabelecidos, sem perderem um átomo de influência e consideração. Sendo assim, não se compreende o terror do padre Amaro, no dia em que do seu erro the nasce um filho, e muito menos se compreende que o mate. Das duas forças que lutam na alma do padre Amaro, uma é real e efetiva o sentimento da paternidade; a outra é quimérica e impossível - o terror da opinião, que ele tem visto tolerante e cúmplice no desvio dos seus confrades; e não obstante, é esta a força que triunfa. Haverá aí alguma verdade moral? (ASSIS, 2008, p. 1233)

Embora se refira a termos moralistas, a crítica de Machado de Assis não espera da parte do personagem uma adequação a uma norma de conduta austera (que copiasse a ambiência do romance de Zola), mas sim uma adequação de suas motivações, considerando-se seu contexto. Ou seja, a "verdade moral" questionada diz respeito à formação do padre Amaro como personagem e à sua verossimilhança em termos psicológicos e sociais. Esses pontos se desdobram, por fim, no efeito de verossimilhança da trama.

Apesar de Machado de Assis satirizar o clero de O Padre Amaro, é antes a "verdade moral" do protagonista e suas ações no romance que Machado questiona. O foco da crítica machadiana direciona-se à articulação das motivações do personagem em relação com a trama. De forma semelhante, a respeito de $O$ primo Basílio, Machado critica, sobretudo, a "inépcia" da constituição da protagonista Luísa e o foco recai mais uma vez sobre suas motivações. 
Dessa forma, entre as falhas do romance O primo Basílio, Machado condena as seguintes: a descrição excessiva, típica da escola; o tom carregado das cenas em termos eróticos ou grosseiros, aspecto que o autor também atribui à escola; o emprego de ações fortuitas como solução para a trama; e principalmente, a falta da qualidade "moral" nas personagens, que resulta em defeito no desenvolvimento da trama. Ou seja, se Luísa não tem motivações ou paixões que a constituem como personagem, a trama do romance perde em termos de articulação, pois não se desenrola a partir da "verdade moral" da protagonista.

Machado critica, mais uma vez, Eça por contraste às referências francesas da escola realista ${ }^{2}$ e desqualifica, em especial, Luísa, chamando-a de "títere" e "caráter negativo" em comparação à Eugênia Grandet:

$\mathrm{Na}$ Eugênia [Grandet], há uma personalidade acentuada, uma pessoa moral, uma figura moral, que por isso mesmo nos interessa e prende; a Luísa - força é dizê-lo - a Luísa é um caráter negativo, e no meio da ação ideada pelo autor, é antes um títere do que uma pessoa moral.

Repito é um títere; não quero dizer que não tenha nervos e músculos; não tem mesmo outra coisa; não the peçam paixões nem remorsos; menos ainda consciência (ASSIS, 2008, p. 1233 [grifo meu]).

Portanto, Machado ataca Luísa, em especial, no que diz respeito à falta de paixões e consciência. O escritor argumenta sobre a ausência de implicações morais no início da traição de Luísa, que é uma das ações centrais do romance de Eça:

\footnotetext{
${ }^{2}$ Quando Machado criticava Eça em relação aos modelos franceses, observava-Ihe a originalidade da adaptação, mas, por fim, apontava um defeito de concepção no romance. Roberto Schwarz, em Ao vencedor as batatas, comenta brevemente o que chama de "militância anti-realista de Machado de Assis" em alguns de seus artigos do mesmo período, "Instinto de nacionalidade", "A nova geração", e o próprio "O primo Basílio". Schwarz considera que essa atitude conservadora de Machado de Assis possuía uma intenção realista. A observação segue a interpretação schwarziana sobre como Machado apropriou-se da matéria local, deslocando-a para o centro formal de seu romance, diferentemente de seus contemporâneos. Nesse sentido, a crítica de Machado a Eça de Queirós quanto à recepção dos romances franceses realistas é um problema correlato ao deslocamento operado por Machado em relação ao romance de Alencar, no Brasil: "[...] Conforme anunciávamos, o acessório localista de Alencar tornou-se força formal, e as audácias cosmopolitas de seu conflito central reduzem-se ao que no fundo sempre foram, a elementos de moda. São passos da redistribuição mais verossímil de tramas e acentos operada por Machado, redistribuição que por sua vez não se fazia sem problemas. [...] Para avaliar as ambigüidades desse percurso, tome-se a militância anti-realista de Machado de Assis, em cujas palavras o Realismo "é a negação mesma do princípio da arte" [...]. No entanto, havia da parte de Machado uma intenção realista neste antirrealismo conservador, se o considerarmos expressão de experiência e ceticismo - o que não era na Europa, onde representava um recuo intelectual - em face do cabimento das idéias liberais no Brasil. Destinado a esfumar os antagonismos do regime burguês, o anti-realismo não os postulava, e nos poupava a ilusão de sermos a França... Mesmo a exclusão do assunto baixo, em espécie as misérias modernas, ocasionadas pelo Capital, era para nós a exclusão de um assunto com tropismos frívolos. [...]" (SCHWARZ, Roberto, 2000, p. 86-87).
} 
[...] Tal é o intróito de uma queda, que nenhuma razão moral explica, nenhuma paixão, sublime ou subalterna, nenhum amor, nenhum despeito, nenhuma perversão sequer. Luísa resvala no lodo, sem vontade, sem repulsa, sem consciência; Basílio não faz mais do que empuxá-la, como matéria inerte, que é. Uma vez rolada ao erro, como nenhuma flama espiritual a alenta, não acha ali a saciedade das grandes paixões criminosas: rebolca-se simplesmente (ASSIS, 2008, p. 1235).

A falha, segundo a abordagem de Machado, está em que Luísa não nos permite entrever motivação alguma. Machado cita que Luísa apresenta concupiscência apenas, observação de fato moralista. No entanto, a falta mais grave seria a constituição moral nula da personagem que redunda em composição artística falha, ao levar a um problema de concepção do romance.

Nesse sentido, o recato de Machado de Assis contra o apelo sensual do livro deixa de ser o argumento mais relevante e o que vem à tona como argumento principal é a constituição da personagem segundo uma "verdade moral" em função da trama como um todo. Embora num nível imediato da crítica haja advertências de Machado contra o "pomo defeso" (ASSIS, 2008, p. 1234) enquanto tema do romance, em outros níveis, há uma questão estética apresentada pelo escritor brasileiro.

Notemos, portanto, que se Luísa fosse perversa e se esta característica moral fosse o motor de suas ações, a personagem satisfaria as exigências críticas de Machado de Assis. O comedimento do crítico, no fim, visa não a uma moral virtuosa, mas sim a uma conformação verossímil dos personagens. Como Luísa não é assim composta, o erro maior estaria na passagem da falta de motivações na constituição da protagonista para uma falta de significado na trama do romance:

Assim, esta ligação de algumas semanas, que é o fato inicial e essencial da ação, não passa de um incidente erótico, sem relevo, repugnante, vulgar. Que tem o leitor do livro com essas duas criaturas sem ocupação nem sentimentos? Positivamente nada.

E aqui chegamos ao defeito capital da concepção do Sr. Eça de Queirós. A situação tende a acabar, porque o marido está prestes a voltar do Alentejo, e Basílio começa a enfastiar-se, e, já por isso já porque o instiga um companheiro seu, não tardará a trasladar-se a Paris. Interveio, neste ponto, uma criada (ASSIS, 2008, p. 1234).

O que Machado chama com duras palavras de "o defeito capital da concepção do Sr. Eça de Queirós" é, portanto, a falta de "verdade moral" das 
personagens que implica em falta de "verdade moral" da ação. Nesse sentido, Machado critica a "substituição do principal pelo acessório" (ASSIS, 2008, p. 1237). Como Luísa não nos prende por si própria e como ela é um joguete na mão de outros personagens, sua conformação moral e artística não constitui um motor para a narrativa, o que leva Eça, segundo o julgamento de Machado de Assis, a buscar lances fortuitos em que a protagonista deixe de ser levada por um personagem para ser chantageada por outro.

Assim, torna-se compreensível por que, para Machado, o "caráter mais completo e verdadeiro do livro" (ASSIS, 2008, p. 1235) é Juliana. Muito possivelmente por esta personagem exibir na sua constituição motivações como o desejo de vingança e de manipulação, ela é salva aos seus olhos. Dessa forma, quando escreve sobre Juliana, Machado enfoca justamente seus desejos, ou seja, deixar de servir e enriquecer:

[...] Juliana, o caráter mais completo e verdadeiro do livro; Juliana está enfadada de servir, espreita um meio de enriquecer depressa; logra apoderar-se de quatro cartas; é o triunfo, é a opulência (ASSIS, 2008, p. 1235).

Ademais, Machado alude à função da personagem no quadro geral da trama, referindo-se, principalmente, à sua índole:

Suponhamos que tais cartas não eram descobertas, ou que Juliana não tinha a malícia de as procurar, ou enfim que não havia semelhante fâmula em casa, nem outra da mesma índole (ASSIS, 2008, p. 1235).

Por fim, na segunda parte da crítica, quando tenta defender-se da polêmica que havia levantado com a primeira apreciação sobre O primo Basílio, Machado reconhece mais uma vez o que considera como perfeição da personagem Juliana, referindo-se a ela novamente pelo termo "caracteres":

[...] Não advertiu que, além de proclamar o talento do autor, (seria pueril negar-lho) e de the reconhecer o dom da observação, notei o esmero de algumas páginas e a perfeição de um dos seus caracteres. Não me parece que isto seja negar tudo a um livro, e a um segundo livro (ASSIS, 2008, p. 1238).

Portanto, segundo a defesa de Machado, existe uma estreita articulação entre a constituição dos personagens e a concepção do romance. Neste artigo de 1878, os personagens são bem qualificados apenas quando trazem em sua composição uma "pessoa moral". Por sua vez, a composição dos personagens faz com que a 
obra ganhe em termos de "verdade estética". Assim, quando escreve a segunda parte da crítica, o autor retoma o argumento de que a situação moral dos personagens constitui o elemento principal do drama:

[...] Releiam-me; lá verão que, depois de analisar o caráter de Luísa, de mostrar que ela cai sem repulsa nem vontade, que nenhum amor nem ódio a abala, que o adultério é ali uma simples aventura passageira, chego à conclusão de que, com tais caracteres como Luísa e Basílio, uma vez separados os dois, e regressando o marido não há meio de continuar o romance, porque os heróis e a ação não dão mais nada de si, e o erro de Luísa seria um simples parênteses no período conjugal. [...] Que acontecimento, logicamente deduzido da situação moral dos personagens, podia vir continuar uma ação extinta? Evidentemente nenhum. Remorsos? [...] Tirai o extravio das cartas, a casa de Jorge passa a ser uma nesga do paraíso; sem essa circunstância, inteiramente casual, acabaria o romance. Ora, a substituição do principal pelo acessório, a ação transplantada dos caracteres e dos sentimentos para o incidente, para o fortuito, eis o que me pareceu incongruente e contrário às leis da arte (ASSIS, 2008, p. 1239).

Ainda na mesma linha de argumentação, Machado se refere a Shakespeare:

O lenço de Desdêmona tem larga parte na sua morte; mas a alma ciosa e ardente de Otelo, a perfídia de lago e a inocência de Desdêmona, eis os elementos principais da ação. O drama existe, porque está nos caracteres, nas paixões, na situação moral dos personagens: o acessório não domina o absoluto; é como a rima de Boileau: il ne doit qu'obeir. Extraviem-se as cartas, faça uso delas Juliana; é um episódio como qualquer outro. Mas o que, a meu ver, constitui o defeito da concepção do Sr. Eça de Queirós, é que a ação, já despida de todo o interesse anedótico, adquire um interesse de curiosidade. Luísa resgatará as cartas? Eis o problema que o leitor tem diante de si. A vida, os cuidados, os pensamentos da heroína não têm outro objeto, senão esse (ASSIS, 2008, p. 1239).

É interessante que, na última frase do excerto, Machado mencione as seguintes esferas relativas à conformação da protagonista: "a vida, os cuidados, os pensamentos" (ASSIS, 2008, p. 1239). Creio que na abordagem desta crítica de Machado de Assis podemos alcançar reflexões mais produtivas em relação à obra do próprio autor brasileiro do que em relação ao romance de Eça de Queirós.

José Luís Jobim (2010) abordou o artigo de Machado de Assis, aliás, fugindo da polêmica sobre a pertinência dos julgamentos quanto ao romance de Eça. Uma das conclusões de Jobim em relação à crítica a $O$ primo Basílio diz respeito à orientação de Machado em seu próprio projeto ficcional de se distanciar da 
descrição inventariante de elementos externos, deslocando-se para o enfoque da vida interna dos personagens, justamente aquele elemento que Machado nomeia como "pessoa moral" do personagem:

Se nos distanciarmos da necessidade de encontrar razão ou não neste argumento em relação a Eça, e pensarmos nesta linha de argumentação como matriz de um contraste que ele, Machado, vai constituir na sua escrita, em relação ao que acredita ser o cerne da prática inventariante praticada pelo Realismo/Naturalismo, podemos chegar a conclusões interessantes. A principal, talvez, seja a de que Machado, a partir da crítica à descrição exterior de situações e personagens (que, aliás, não aparece apenas ao tratar de Eça), já abre terreno para propostas diferentes - por exemplo, de abordagem mais interiorizada da vida e das ações de personagens, o que vai marcar sua chamada "fase madura" como romancista. Assim, ele está falando do seu próprio projeto de escrita, ao falar do Realismo e deste livro de Eça (JOBIM, 2010, p. 90).

A partir da crítica machadiana a $O$ primo Basílio, é meu interesse, portanto, destacar a presença do mundo interior dos personagens enquanto elemento relevante no projeto estético e ético de Machado de Assis. Ou seja, a forma, como "a vida, os cuidados, os pensamentos" (ASSIS, 2008, p. 1239) dos protagonistas são centrais nos contos aqui abordados.

Aliás, na segunda parte da crítica, que constitui resposta do autor aos seus "contendores", Machado retoma, principalmente, a objeção que havia feito quanto à substituição do principal pelo acessório no sentido do recurso de lances fortuitos e da descrição excessiva de quadros externos. Machado, mais uma vez, dirige seus argumentos contra o realismo de escola. No fim do texto, há grande ênfase na superficialidade da descrição de ambientes e de elementos externos do realismo/naturalismo, como se esta atitude descritiva fosse justamente o acessório sem sustentabilidade que toma o lugar do elemento principal num drama:

[...] Este messianismo literário não tem a torça da universalidade nem da vitalidade; traz consigo a decrepitude. Influi, decerto, em bom sentido e até certo ponto, não para substituir as doutrinas aceitas, mas corrigir o excesso de sua aplicação. Nada mais. Voltemos os olhos para a realidade, mas excluamos o realismo, assim não sacrificaremos a verdade estética.

Um dos meus contendores louva o livro do sr. Eça de Queirós, por dizer a verdade, e atribui a algum hipócrita a máxima de que nem todas as verdades se dizem. Vejo que confunde a arte com a moral; vejo mais que se 
combate a si próprio. Se todas as verdades se dizem, por que excluir algumas?

Ora, o realismo dos srs. Zola e Eça de Queirós, apesar de tudo, ainda não esgotou todas os aspectos da realidade. Há atos íntimos e ínfimos, vícios ocultos, secreções sociais que não podem ser preteridas nessa exposição de todas as coisas. Se são naturais, para que escondê-los? Ocorre-me que Voltaire, cuja eterna mofa é a consolação do bom senso (quando não transcende o humano limite), a Voltaire se atribui uma resposta, da qual citarei apenas metade: Très naturel aussi, mais je porte des culottes (ASSIS, 2008, p. 1242).

Portanto, Machado considerava as novas escolas - realismo e naturalismo apenas no que elas pudessem corrigir cacoetes dos movimentos anteriores, mas não as aceitava enquanto escolas que propusessem uma anulação de um legado literário.

Pensando num circuito que vai da escrita crítica de Machado de Assis à sua escrita ficcional, podemos observar, por exemplo, o desdobramento da ideia sobre os "atos íntimos e ínfimos" na obra do autor. Ou melhor, é notável em sua ficção o emprego contido de detalhes e a descrição condensada de personagens.

Assim, outra objeção de Machado ao realismo de escola é a descrição excessiva. Machado aponta novamente para um problema de representação literária. Há na sua defesa a consideração de que a realidade é impossível de ser abarcada completamente. Assim, não convém à arte um inventário de quadros externos. Nesse sentido, ele ironiza, ao sugerir a necessidade de se voltar os olhos para a realidade, não para o realismo. Machado defende, portanto, a "verdade estética", ou seja, a obra de arte enquanto representação convencional.

A mofa de Voltaire, por exemplo, diz respeito à defesa do filósofo da "bela natureza", isto é, das regras da arte, por oposição à presença da "natureza em si" nas obras ${ }^{3}$. A citação de Voltaire pela metade é um recurso irônico do qual Machado lança mão para obliterar justamente o termo baixo usado pelo filósofo, que agradaria

\footnotetext{
${ }^{3}$ A referência sobre a expressão de Voltaire provém da tese de Rodrigo Brandão, $A$ ordem do mundo e do homem: estudos sobre metafísica e moral em Voltaire. Na introdução da tese, Brandão discorre sobre a diferença entre os conceitos de gênio e gosto em Voltaire. A "bela natureza" relaciona-se com as regras da arte e com o decoro e é formada, a partir da tradição e com o tempo. O comentário contra o tema e caracteres baixos em Shakespeare é retomado por Brandão, por sua vez, para exemplificar a diferença entre "bela natureza" e "natureza pura e simples" em Voltaire. (BRANDÃO, 2008, p. 31).
} 
à escola que Machado tanto critica: "Avec votre permission, monsieur, lui répliqua Voltaire, mon cul est bien dans la nature, et cependant, je porte de cullottes"4.

Assim, no fim da crítica, Machado defende, sobretudo, a obra de arte enquanto convenção, não enquanto transposição da realidade externa ou da natureza em descrições que almejem ser cópia fiel. Contudo, a citação de Voltaire apresenta uma contradição no texto de Machado. Em seu contexto, o filósofo francês condenava a inserção do que é considerado baixo na tragédia por Shakespeare, enquanto Machado de Assis desenvolvia um movimento inverso em relação ao dramaturgo inglês. Pois, como já mencionado, Machado encontra em Shakespeare um exemplo expressivo para seus argumentos em relação ao interesse na situação moral, nas paixões e nos caracteres enquanto motor do drama. Porém, é interessante que, mesmo tendo feito a ressalva contra os termos e caracteres baixos do escritor inglês, Voltaire também admirasse a inventividade de Shakespeare (BRANDÃO, 2008, p. 31).

O tom rigoroso e as polêmicas relativas à crítica a $O$ primo Basílio assinalam, portanto, um momento de crise em que Machado de Assis fazia frente a pressupostos limitantes do realismo de escola, que era praticado enquanto "reprodução fotográfica e servil" (ASSIS, 2008, p. 1233) dos quadros externos da realidade. Em outra chave, essa crítica à "reprodução fotográfica e servil" pode ser interpretada como crítica à reprodução indiscriminada de um movimento literário em voga.

À época da publicação desse texto sobre O primo Basílio, Machado de Assis procurava, ao mesmo tempo, definir sua própria concepção de romance, o que justifica, mais uma vez, que leiamos o texto em relação à sua obra de ficção. Notemos, por exemplo, que no mesmo ano Machado publicava laiá Garcia. Dessa forma, o complexo da "pessoa moral" dos personagens, do trabalho dos "caracteres"

\footnotetext{
4 "Nas Lettres d'un voyageur anglais sur la France, 1781-178?, récit d'une visite faite à Ferney en 1776, John Moore narra uma pequena história que deixa entrever a distinção entre bela natureza e a natureza pura e simples. Ele diz: "Un soir, à Ferney, où il fut question dans la conversation du gênie de Shakespeare, Voltaire déclama contre l'impropriété et l'absurdité qu'il y avait d'introduire dans la tragédie des caractères vulgaires et un dialogue bas et rampant; il cita plusieurs exemples où notre poète avait contravenue à cette règle, même dans les pièces les plus touchantes. Un monsieur de la compagnie, qui est un admirateur zélé de Shakespeare, observa, en cherchant à excuser notre célèbre compatriote, que, quoique ses caractères fussent pris dans le peuple, ils n'étaient pas moins dans la nature. "Avec votre permission, monsieur, lui répliqua Voltaire, mon cul est bien dans la nature et cependant, je porte des cullottes »." Apud Henri Lagrave. In : Inventaire Voltaire. Sous la direction de Jean Goulemot, André Magnan, et Didier Masseau. Quarto/ Gallimard. Paris, 1995, p. 1246" (BRANDÃO, 2008, p. 31).
} 
e da "verdade estética" da obra enquanto questionamento sobre formas e limites da representação ficcional já era relevante no artigo de 1878.

O que podemos depreender da crítica a O primo Basílio é que, para Machado, o valor da ficção está na composição dos personagens e das ações em função de sua densidade moral que reflete, por sua vez, na "verdade moral" da trama. Contudo, como ler um termo que, para nós, parece tão carregado como "verdade moral"? Se atentarmos ao primeiro argumento lançado por Machado sobre $O$ crime do Padre Amaro, perceberemos que "verdade moral" tem, entre seus significados possíveis, o mesmo que "verdade estética", um dos termos que remata o artigo e possui relação com a noção de representação literária e de verossimilhança. Quando pergunta sobre a "verdade moral" em O Padre Amaro, por exemplo, Machado está questionando uma falta de adequação entre o personagem, sua motivação e seu meio, adequação que, se existisse, tornaria a obra mais verossímil.

No plano dos personagens, a "questão moral" em Machado de Assis terá dois desdobramentos que interessam a este trabalho: um está no âmbito dos caracteres e da "pessoa moral" dos personagens; outro está no âmbito da psicologia do personagem. No primeiro caso, trata-se de uma tradição que é retomada, de forma explícita, por Machado de Assis, que se autodeclara inscrito numa rede que alude à retórica dos caracteres e aos moralistas, como os moralistas franceses do século 17, por exemplo. Nesse sentido, ao mencionar os caracteres e o conceito de "pessoa moral", Machado desenvolve uma composição de personagens que remonta à tradição. No segundo caso, trata-se de interpretações que são posteriores ao autor e que investigam o desdobramento psicológico de muitos dos personagens machadianos enquanto personagens complexos e sujeitos descentrados. Essa interpretação se desenvolveu, segundo uma orientação psicanalítica que, muitas vezes, não se deu de forma declarada, ao longo da crítica machadiana do século 20 (PASSOS, 2009, p. 28).

Assim, podemos observar que, por um lado, Machado moveu a tradição da retórica dos caracteres, do retrato moral e dos moralistas para a constituição de seus personagens. Por outro lado, enquanto Machado dialogava com uma tradição clássica, ele foi um escritor moderno que, a partir do adensamento moral e da preocupação com a vida interna de algumas de suas figuras ficcionais, criou personagens cuja composição implica em questões relativas à psicologia moderna. Nesse sentido, podemos citar, por exemplo, o conto "O espelho", paradigmático em 
relação ao questionamento da identidade e da constituição do sujeito. Assim, as interpretações da chamada "linha psicológica" da crítica machadiana formularam as primeiras indagações em torno desses problemas.

Portanto, creio ser necessária uma revisão da recepção crítica machadiana, no que se refere ao escopo deste trabalho. Primeiramente, retomarei críticos que enfocaram a presença da retórica dos caracteres, do retrato moral e da questão moral em Machado de Assis. Num segundo momento, pretendo tecer considerações sobre a presença de questões relativas à subjetividade e à constituição do sujeito enquanto temas desenvolvidos pela obra machadiana.

Nesse segundo momento, realizarei uma passagem da questão moral para questões relativas à subjetividade em Machado de Assis, já que aquelas implicaram em adensamento psicológico no caso dos personagens complexos. Para tanto, partirei de "O espelho", que dramatiza questões de constituição do sujeito tanto na composição do protagonista, quanto no tema do conto.

\subsection{Da técnica do caráter à personagem como pessoa}

Começarei, portanto, a revisão da recepção de críticos que investigaram a questão moral em Machado de Assis. Primeiramente, gostaria de retomar a hipótese de Ivan Teixeira (2010) no ensaio "Machado de Assis e o costume retórico dos caracteres" porque ela se detém sobre uma técnica de composição de personagens adotada por Machado.

A hipótese defendida por Teixeira é que Machado de Assis se valeu do costume retórico dos caracteres na composição de vários de seus personagens, em especial, na composição de personagens tipificados. A técnica dos caracteres é originária, entre outras fontes, da obra Os caracteres, de Teofrasto. A partir dessa hipótese, Teixeira analisa a galeria de personagens de "O alienista". Para tanto, o crítico declara desvincular-se do conceito de "influência" entre autores. Ademais, Teixeira aborda o livro Os caracteres, levando em consideração uma rede de autores que desenvolveu o costume dos caracteres: inicialmente Teofrasto, nos séculos IV e III A.C.; Joseph Hall, Thomas Overburry e John Earle no séc. 17, na Inglaterra; e La Bruyère no séc. 18, na França. O costume do caráter também foi praticado por Plutarco (I A.C.- I D.C.) e retomado por Swift, Sterne, Fielding e pelo próprio Machado de Assis (TEIXEIRA, 2010, p. 69-70). 
Assim, Teixeira (2010, p. 70) afirma: "Tenho convicção de que todas as personagens de $O$ alienista são tipos desenhados conforme a tradição de $O s$ caracteres de Teofrasto". Teixeira (2010, p. 73) menciona, portanto, a preocupação de Machado com as regras da composição literária ("decoro artístico") e com a verossimilhança, o que percebemos também ao nos debruçarmos sobre o artigo "Literatura Realista - O primo Basílio". O crítico menciona, ademais, a tradição dos caracteres presente em outros autores brasileiros do século 19 como Alencar e Pompéia (TEIXEIRA, 2010, p. 73).

Os caracteres, de Teofrasto, é uma obra composta de trinta vinhetas de perfis morais, que contém uma breve introdução do filósofo (proêmio) conferindo unidade ao conjunto. Os perfis apresentam primeiramente um vício, de forma conceitual, dissimulação, bajulação, tagarelice, etc. - e então traçam a caracterização do vício, de forma condensada. Por fim, o texto desenvolve o efeito de uma personagem arquetípica. O livro, portanto, apresenta uma galeria de caracteres e tem função instrutiva na composição de personagens, além de função satírica e moralizante. Outras funções do livro são discutidas no ensaio de Teixeira (TEIXEIRA, 2010, p. 84-87).

$\mathrm{Na}$ introdução de Os caracteres, Teofrasto menciona exemplos de vício e virtude, mas apenas os vícios são representados de forma direta na galeria do livro (MALHADAS, 1978, p. 32). Essa característica do tratado é muito importante porque os caracteres em Teofrasto são exemplos de personagens negativos ou excessivos em relação à norma aristotélica e, de forma semelhante, os personagens de Machado de Assis compostos a partir da técnica do caráter são majoritariamente negativos (TEIXEIRA, 2010, p. 73).

Lembremos, por exemplo, que no caso da crítica a O primo Basílio, Machado não defendia personagens que tivessem uma "pessoa moral" como personagens que fossem exemplos de virtude. Assim, podemos observar, por um lado, que a vil Juliana parecia-Ihe um "caráter perfeito": "Juliana, o caráter mais completo e verdadeiro do livro; [...]" (ASSIS, 2008, p. 1235). Por outro lado, Luísa parecia-lhe um "caráter negativo" porque a entendia como personagem de composição negativa. Ou seja, Luísa era inverossímil, segundo a concepção de personagens que está sendo referenciada por Machado de Assis, a saber, a "retórica dos caracteres". Portanto, a "retórica dos caracteres" e o "retrato moral" consistem em técnicas de composição de personagens. Assim, Machado empregou palavras como "caráter" e 
"moral" nos seus ensaios críticos enquanto palavras inscritas no campo da tradição retórica.

Vejamos abaixo a forma como Ivan Teixeira condensou alguns dos elementos da técnica de composição do caráter:

$\mathrm{Na}$ tradição anglo-americana, o desenho verbal do caráter tem sido considerado manifestação de um gênero literário bem caracterizado. Enquanto forma artística, essa espécie de desenho moral encarna traços convencionais normalmente associados a certos tipos psicológicos ou grupos sociais. [...] Uma das primeiras propriedades do caráter como resultado de prática consciente - tal como se percebe, sobretudo, em Teofrasto e em seus continuadores ingleses e franceses - seriam a brevidade e a enumeração, associadas à agudeza, ao engenho e à deformação dos traços. Visa ao efeito rápido, de cujo propósito resulta a adoção do estilo entrecortado da máxima. Procurando justificar a etimologia do termo, a arte do caráter pretende causar impressão forte. Em vez de representar as particularidades de um indivíduo, mimetiza a somatória de características de outras pessoas. Sendo representação de sinais coletivos, será também uma personagem que simboliza personagens. Variante do que se conhece na atualidade por personagem plana, essa modalidade oferece traços fixos, sem sofrer alteração essencial no desenvolvimento das estórias. O tipo imaginado no caráter antigo não pretende sugerir nenhuma intimidade psicológica, mas certos sintomas ou ações exteriores, previamente codificadas pelo costume. Por sua natureza especular e metonímica, aproxima-se da personagem alegórica. Muitos pormenores contribuem para a construção do caráter, entre os quais se contam: comportamentos ou gestos repetidos, previsibilidade na maneira de falar, exagero de propriedades representativas, traços simbólicos na roupa ou nos pertences, produção do efeito de concretude realista e abordagem do particular para insinuar o geral.

Entendidas como adstritas a um gênero literário, tais propriedades criam uma dificuldade conceitual, pois se fundam em aparente paradoxo, que se pode explicar mais ou menos nos seguintes termos: por um lado, o caráter ambiciona o geral, mas focaliza o particular; por outro, compõe-se da estilização de traços convencionais, mas produz sensação de realidade singular. [...] (TEIXEIRA, 2010, p. 78-79).

No desenho moral, os caracteres partem necessariamente de um conceito moral e desembocam em personagens de "efeito realista" em função da concretude dos detalhes. Assim, a forte condensação dos detalhes confere-lhes contraditoriamente qualidade expansiva. No entanto, os personagens compostos 
segundo a técnica do caráter, ainda que sejam aparentemente particulares, continuam a ter qualidade alegórica.

Lembremos novamente que na crítica a O primo Basílio, Machado condenava a substituição do principal - as paixões, os caracteres e a situação moral no drama pelo acessório, ou seja, a descrição excessiva e demorada de quadros externos. No caso dos escritores que desenvolveram personagens por meio do costume dos caracteres (entre eles, o próprio Machado), o detalhe é empregado enquanto elemento condensado que particulariza num personagem bem acabado certo vício moral ou determinado traço psicológico.

A partir dessa consideração, portanto, encontramos mais um argumento para ler a crítica de Machado de Assis ao romance de Eça de Queirós como projeção de referências e técnicas que o autor adotava para seu próprio processo criativo. Pois o uso do detalhe no realismo de escola - empregado de forma dispendiosa - é oposto ao uso do detalhe ao qual Machado se voltava. Ou seja, segundo a tradição referida por Machado de Assis, o detalhe deveria ser empregado de forma condensada, visando paradoxalmente à expansão.

Ao pensar sobre a questão do estilo descritivo dos caracteres, creio ser interessante perceber duas orientações do desenho moral apontadas por Ivan Teixeira. Trata-se da diferença entre "caráter" e "retrato moral". Embora essas orientações do desenho verbal sejam fluidas e não estanques, elas apontam em direções distintas: uma é relativa ao "personagem plano"; outra é relativa ao "personagem complexo", individualizado, que pode apresentar tanto existência histórica, quanto traços que Ihe conferem uma psicologia singular.

Quando o termo [caracteres], nas Suplicantes de Ésquilo (ca. 463 a. C.), entrou para a representação verbal do mundo, assumiu o sentido de aparência pessoal, por oposição à representação de qualquer suposta individualidade interior. A inclusão da ideia de predomínio do traço exterior ao conceito de caráter associa-se à prática da produção mecânica em série, visto que não era costume cunhar moedas individualmente. Decorre daí a tradição conceitual que estabelece certa diferença entre caráter e retrato. No primeiro, o efeito produzido pelo desenho deveria associar-se à ideia de que se trata de um tipo, e não de um indivíduo. O segundo caso, fugindo da tipologia cômica de traços conhecidos, deveria desencadear uma imagem única e inesperada. Essa será, com certeza, uma descrição das duas modalidades da pintura moral, pois, dependendo da perícia do escritor, o perfil pode atingir graus poucos precisos de definição - propriedade capaz 
de ampliar o alcance estético do esboço (TEIXEIRA, 2010, p. 80-81 [grifo meu]).

Assim, Teixeira distingue "caráter" de "retrato". O crítico diferencia, por exemplo, os perfis de "O empréstimo" e de "Verba testamentária", que podem ser considerados caracteres da ordem do tipo, da pintura moral de "D. Benedita", que pode ser considerada um retrato singular (TEIXEIRA, 2001, p. 89).

Da mesma forma, quando Teixeira analisa a cena em que D. Evarista, mulher de Simão Bacamarte, de "O alienista", resiste à notícia da rebelião que é dada por um menino escravo, o crítico faz novamente a distinção entre tipo e atributo psicológico individual. O trecho do conto machadiano é o seguinte: "Quanto ao moleque, a quem D. Evarista não dera crédito, teve um instante de triunfo, um certo movimento súbito, imperceptível, entranhado, de satisfação moral, ao ver que a realidade vinha jurar por ele" (ASSIS, 2008, p. 253).

Enquanto Teixeira considera, por um lado, a descrição de D. Evarista e da mucama como tipos bem acabados, ele interpreta, por outro lado, o lampejo do garoto como uma fuga da ordem estabelecida e uma descrição de seu mundo interno. A satisfação moral do jovem relativiza a noção do tipo em sociedade. A descrição do personagem, portanto, sai das características do tipo e vai em direção ao desenho de uma psicologia individual:

Trata-se de um retrato, mas não será talvez apenas um caráter típico de Teofrasto, porque a pintura representa a psicologia do menino, que ostenta uma alma sensível aos estímulos do ambiente. Tendo demonstrado que nada tinha de "tolo", entrega-se ao prazer de se perceber um pouco acima da própria condição (TEIXEIRA, 2010, p. 96).

Neste trabalho, enfocarei principalmente personagens próximos do retrato moral e de uma composição singular. Para tanto, considera-se que a pintura de perfis na obra de Machado partiu da retórica dos caracteres, proporcionando uma galeria de tipos, mas também se diversificou, ao criar personagens individualizados. A prática do costume retórico dos caracteres favoreceu, desde o início, na obra machadiana, o trabalho da densidade moral e psicológica dos personagens tipológicos, pois o motor para a composição dos caracteres traz um conceito moral ou um tipo psicológico como ponto de partida.

\footnotetext{
${ }^{5}$ Termo da personagem d. Evarista.
} 
Quando Machado desenhou personagens singulares, o adensamento moral e psicológico persistiu, sendo investido, contudo, na criação de figuras de aspecto único. Assim, a abordagem deste trabalho objetiva, principalmente, à análise de personagens singulares ou temas que, diferentemente dos tipos, "sugerem intimidade psicológica”, segundo expressão de Ivan Teixeira (TEIXEIRA, 2010, p. 80).

É interessante que Pedro Meira Monteiro (2010), por exemplo, tenha abordado a arte do retrato como pintura moral em Machado de Assis, em especial, no ensaio "Falo das linhas vistas: um esboço sobre a arte do retrato no Memorial de Aires". Monteiro retoma Merleau-Ponty, Augusto Meyer, Alfredo Bosi e José Luiz Passos e enfoca o poder de sugestão da narrativa machadiana, no sentido de evocar o enigma do sujeito, ao descrever o personagem em sua singularidade e inefabilidade.

Assim, Monteiro (2010, p. 78-79) cita a passagem de 25 de janeiro de 1888 do Memorial em que Aires, ao descrever Fidélia, fala de seus contornos visíveis, imanentes, sugerindo, porém, o que é inapreensível aos olhos. Ou seja, o conselheiro fala das linhas visíveis, mas sugere também as linhas não vistas da viúva.

Consequentemente, outro ponto que Monteiro aborda na obra machadiana é a conformação moral do olhar do narrador Aires. Assim, Monteiro cita que a questão moral evidencia-se como tema da narrativa, a partir da busca de Aires por perscrutar personagens e sujeitos que são, a rigor, insondáveis. Pedro Meira Monteiro conclui: "Penso que não seja difícil compreender que é a natureza moral do sujeito, da pessoa, que se coloca no centro de uma análise que é menos dissecação, e mais insinuação. Não é um cientista que escreve, mas um poeta que simula" (MONTEIRO, 2010, p. 80).

Devemos lembrar que as categorias do caráter e do retrato não são estanques e que, muitas vezes, o mesmo personagem traz em si traços do tipo e do indivíduo singular, simultaneamente, ou em diferentes momentos da narrativa. Alfredo Bosi, ao investigar a tonalidade e a genealogia moral do olhar machadiano, desenvolveu, por exemplo, uma reflexão sobre a diferença entre "indivíduo", "tipo" e "pessoa" na obra de Machado de Assis.

Em "Uma hipótese sobre a situação de Machado de Assis na literatura brasileira", Bosi (2007, p. 159) descreve o "indivíduo" como "veleitário", não fixado, e 
percebido pelo leitor, a partir de "projeções efêmeras". O "tipo" seria, por sua vez, uma espécie de estabilização, em que um personagem se conforma em determinantes sociais e psicológicas cujas referências encontram-se na realidade externa (BOSI, 2007, p. 200). A "pessoa" seria o personagem que se desprende do tipo, apesar de partir dele. Assim, a pessoa enquanto categoria de personagem não se encontra totalmente constrangida por seus condicionamentos:

Por sua vez, a pessoa é a negação dialética do tipo, já ossificado e preso às suas determinações. A pessoa, enquanto capaz de exercer a vontade de refletir suas relações com os outros, é mais concreta, mais autoconsciente e, por hipótese, mais livre do que o tipo; o que não significa que a sua existência se desenrola em um plano ideal, longe das pressões sociais. Ao contrário, a força da pessoa se afirma dentro da máquina social e, em certos momentos, contra esta.

Indivíduo, tipo, pessoa: trata-se de uma rede dinâmica de possibilidades, um processo de inerência, e não de exclusões definitivas. $O$ indivíduo, que Machado flagra praticando este ou aquele ato aparentemente gratuito (mas, no fundo, movido pelo desejo ou pelo medo, universais do comportamento), poderá entrar e, em geral, acaba entrando para o conjunto limitado de caracteres que o marcarão como tipo. Esse é tantas vezes o destino que the foi reservado pelo meio, pela classe, pela educação ou simplesmente pela cor de sua pele. A sua margem de liberdade e escolha parece então mínima ou nula, e é nesta condição que o colhe e o descreve o discurso sociológico não raro combinado com uma explicação funcionalista dos comportamentos: cada tipo guardaria em si a ideologia correspondente à sua particularidade social. A ficção passa a ser um inventário de situações típicas, personagens típicas e idéias típicas de personagens em situação.

De todo modo, há em Machado mais do que simples inventário: há invenção. E essa inventividade do romancista permitiu-lhe seguir, graças à mobilidade do seu olhar, os movimentos públicos ou íntimos de personagens, que ora vivem segundo o capricho de sensações imediatas, isto é, vivem como indivíduos na acepção negativa de mônadas exteriores umas às outras; ora comportam-se como tipos agindo de acordo com os cálculos necessários para manter ou elevar o próprio status; ora, enfim, podem trazer em si o aguilhão da consciência da sua dignidade como pessoas, sem que essa rara disposição interior seja automaticamente causada pela sua classe econômica (BOSI, 2007, p. 160-161).

Assim, poderíamos complementar a citação do excerto de Bosi com uma reflexão sobre os personagens retomados acima. Dessa forma, observamos que o 
menino escravo de "O alienista", D. Benedita, Aires e Fidélia apontam em direção à pintura de personagens individualizados, ou seja, em direção ao que poderíamos chamar de "retrato". Ademais, esses personagens sugerem intimidade psicológica e consciência como pessoa enquanto categoria filosófica. A categoria de personagem como pessoa para abordar figuras machadianas únicas e, por vezes, inefáveis, foi desenvolvida justamente pelos críticos Alfredo Bosi (2007), José Luiz Passos (2007) e Pedro Meira Monteiro (2010).

Contudo, o que devemos observar é que em outros momentos da narrativa e se abordados por outras características e ângulos, esses personagens não estão acima do meio em que se encontram. Não pairam como essências. No entanto, têm consciência própria. Novamente, voltamos à questão de categorias não estanques. Ou seja, na pintura moral, os limites entre o caráter e o retrato podem ser diluídos, conforme a perícia do autor e o alcance estético do desenho, segundo Teixeira (2010, p. 81). Ao mesmo tempo, observamos, a partir da leitura do ensaio de Bosi e das categorias de composição de personagem por ele propostas, a defesa de que o tipo nasce da pessoa, assim como o inverso pode também ocorrer: "Rasgos individuais erráticos, tipo e pessoa entretêm, na síntese viva da escrita ficcional, relações de inerência e de passagem de que não dá conta o discurso classificador" (BOSI, 2007, p. 162).

Curiosamente, ao tecer considerações sobre esses matizes e oscilações nos personagens machadianos, Bosi retoma justamente o conto "O espelho", exemplificando as múltiplas facetas de só um personagem, a partir do caso de Jacobina:

Lembro, nessa ordem de idéias, um conto extraordinário, "O espelho". Jacobina, o protagonista, ao receber o título e a farda de alferes, passa a existir exclusivamente como tipo: "o alferes eliminou o homem". Jacobina só se reconhece a si mesmo enquanto se espelha no olhar do outros, provando assim que a forma social imposta de fora é a matriz da sua identidade. Sem a farda, signo visível da sua "alferidade", a personagem se vê decomposta em farrapos de sensações e imagens, carente de unidade. O tipo social tinha incorporado em si as veleidades do indivíduo e lhe dera forma estável. Essa, porém, é apenas meia verdade, pois quem conta a história, o narrador em primeira pessoa, tem consciência do que the aconteceu; logo, é um foco de luz que aclara tanto a situação de si próprio antes de assumir o status de alferes quanto a ação da particularidade social que o absorveu. Enquanto narrador reflexivo do seu destino, Jacobina é 
pessoa, ser de autoconsciência e relação, sem as quais a memória e o ato de narrar não teriam sequer condições de articular-se e exprimir-se (BOSI, 2007, p. 161).

A seguir, portanto, abordarei o conto e citarei algumas interpretações paradigmáticas que fazem parte da "crítica psicológica" da obra machadiana. Não se trata propriamente de uma análise de "O espelho", mas antes de uma abordagem do conto para o levantamento de questões relevantes à dissertação.

\subsection{0 paradigma de "O espelho"}

É interessante que Alfredo Bosi retome o conto "O espelho" para ilustrar a fluidez na composição de personagens machadianos, reafirmando que categorias como "indivíduo", "tipo" e "pessoa" não são suficientes para acompanhar a dinâmica complexa do desenho de alguns deles. Segundo sua análise de "O espelho", o tipo conforma estavelmente as veleidades do indivíduo em Jacobina. Contudo, a tipificação de Jacobina apresenta frestas que o fazem cair no "cochicho do nada", quando o personagem se encontra desolado pela solidão (ASSIS, 2008, p. 326). Por fim, as oscilações entre tipo e indivíduo - incluindo a experiência do horror de se perceber sem contornos - só podem ser analisadas por Jacobina enquanto personagem com a qualidade de pessoa. O papel de narrador autorreflexivo, momento cronológico que é posterior na fábula do conto, desenha Jacobina como pessoa porque, a partir dele, o personagem possui acesso ao seu mundo interno e consciência em relação aos seus impasses morais. No entanto, podemos observar que mesmo quando Jacobina é um narrador consciente de sua história, ele se mostra evanescente, pois some da narrativa, de forma inexplicável.

Aliás, a problemática da falta de contornos do personagem é uma das passagens principais de "O espelho". Esse ponto chama atenção para a associação que Bosi estabeleceu em seu ensaio. Ou seja, Bosi associou a dificuldade de bem delinear os movimentos de composição dos personagens machadianos a um personagem que dramatiza essas questões em sua própria história, ao narrar a visão de seu gesto "esgarçado" e a percepção de sua imagem como uma "difusão de linhas" (ASSIS, 2008, p. 327).

Por um lado, Jacobina está intimamente ligado aos problemas de composição de personagens não estável em Machado de Assis. A oscilação dele entre indivíduo, 
tipo e pessoa, ao lado da evanescência, demonstra a insuficiência de linhas rígidas para a apreensão do desenho de alguns dos personagens machadianos. Por outro lado, Jacobina pode ser igualmente associado a uma noção de constituição do sujeito não determinada, cujo trabalho de subjetivação é inesgotável e constantemente reposto, assim como o sujeito descentrado na pulsão, que foi formulado pela teoria psicanalítica (BIRMAN, 1997, p. 37). Ademais, Jacobina é um dos narradores-personagens machadianos que lidam com o impalpável do sujeito. Ou melhor, ele se defronta com o que não pode ser simbolizado, em especial na cena de horror em frente ao espelho.

Passemos ao conto, portanto. "O espelho" foi publicado na Gazeta de Notícias em setembro de 1882, integrando a coletânea de Papéis avulsos (1882). No primeiro parágrafo, lemos:

Quatro ou cinco cavalheiros debatiam, uma noite, várias questões de alta transcendência, sem que a disparidade dos votos trouxesse a menor alteração nos espíritos. A casa ficava no morro de Santa Teresa, a sala era pequena, alumiada a velas, cuja luz fundia-se misteriosamente com o luar que vinha de fora. Entre a cidade, com as suas agitações e aventuras, e o céu, em que as estrelas pestanejavam, através de uma atmosfera límpida e sossegada, estavam os nossos quatro ou cinco investigadores de coisas metafísicas, resolvendo amigavelmente os mais árduos problemas do universo (ASSIS, 2008, p. 322).

Desde o início, há indefinição de limites entre os elementos da cena. Os personagens não se encontram plenamente individualizados porque são contados como quatro "ou" cinco. A casa se encontra num lugar intersticial - o morro - entre o céu, representação do espiritual, e a cidade, representação da vida terrena. A luz está em fusão: a luz natural da lua funde-se à luz das velas. A discussão metafísica é parodiada porque rebaixada. Existe cisão no grupo em função de opiniões díspares. No entanto, a disparidade de votos é amena, já que os debatedores resolvem "amigavelmente os mais árduos problemas do universo" e não há "a menor alteração dos espíritos" (ASSIS, 2008, p. 322).

Augusto Meyer se referiu à ambiência de linhas diluídas na penumbra de "O espelho" por meio da expressão "chiaroscuro subjetivo" - pintura verbal que o crítico também observou em outros momentos da obra de Machado de Assis, como em "Trio em lá menor", no fim de "D. Benedita", em passagens de "O homem célebre", no desenho de Flora e em "Uns braços" (MEYER, 2008, 53). 
Para além da pintura de linhas em estado de fusão no início do conto, existe, ademais, um problema de duplicação da forma que ocorre, em especial, quando a narração em terceira pessoa passa à narração em primeira pessoa. Sandra Guardini Vaconcelos observa, por exemplo, a duplicação das seguintes estruturas narrativas em "O espelho": há dois narradores; dois espaços, a casa em Santa Teresa e o sítio da tia; há dois tempos, o momento da enunciação de Jacobina, quando ele é um capitalista de meia idade, e o tempo da história de alferes, quando tinha vinte e cinco anos e era um homem livre pobre; os ouvintes atônitos, por fim, duplicam a nós, os leitores (VASCONCELOS, 1990, p. 33). Vasconcelos considera que os enigmas no conto decorrem tanto de sua duplicidade "esfumada", quanto do desaparecimento brusco de Jacobina, que choca os leitores que se amparam em convenções realistas (VASCONCELOS, 1990, p. 33).

Assim, o duplo não apenas constitui temática em "O espelho", como também faz parte de sua estrutura formal. A duplicação formal do conto (no fundo, também um espelhamento) reforça a teoria de Jacobina, ou seja, a teoria da natureza dupla da alma humana. No entanto, o binarismo das explicações do narrador-protagonista não convence. Em adição, no final do conto, não há um retorno bem articulado de um narrador a outro. Ou seja, a duplicação como tema e como forma é um dado truncado e problemático da narrativa - questão que abordarei posteriormente.

No segundo parágrafo, Jacobina é descrito pelos atributos externos e por qualidades morais, assim como ocorre na técnica de composição de personagens por meio do costume do caráter. O desenho de Jacobina apresenta brevemente gesto, fala, idade, origem, classe e, por fim, tipo psicológico:

Por que quatro ou cinco? Rigorosamente eram quatro os que falavam; mas além deles, havia na sala um quinto personagem, calado, pensando, cochilando, cuja espórtula no debate não passava de um ou outro resmungo de aprovação. Esse homem tinha a mesma idade dos companheiros, entre quarenta e cinqüenta anos, era provinciano, capitalista, não sem instrução, e, ao que parece, astuto e cáustico (ASSIS, 2008, p. 322). [...]

Notamos que Jacobina é desenhado de forma misteriosa porque ao mesmo tempo em que o narrador o descreve, apresenta algumas indeterminações. Jacobina é o quinto elemento do grupo e poderia ser excluído, sendo um personagem de presença instável. Ao não falar, ele não assume uma posição no debate. Sua idade não é exata, oscilando dentro da média do grupo. "Provinciano", "capitalista" e "não sem instrução" são características genéricas. "Provinciano" quer dizer que ele não é 
um homem da corte, mas não se diz sua origem exata. "Capitalista" quer dizer que é um homem de posses, não um homem pobre livre. "Não sem instrução" indica que é ilustrado, mas não sabemos qual sua formação.

Por um lado, pode-se interpretar que, na sociedade brasileira do 19, simultaneamente capitalista e escravocrata, não importam a origem, os negócios e a formação de um "indivíduo burguês", pois não há liberalismo de fato. Por outro, podemos interpretar que a figura misteriosa de Jacobina constitui-se parcialmente na sombra por dramatizar uma concepção de constituição de sujeito que é instável.

Os traços psicológicos típicos que compõem o protagonista são desenhados pela aparência: "ao que parece" é a frase que modaliza sua descrição psicológica. Essa caracterização coloca em suspeita a "pessoa moral" de Jacobina. Perguntamonos: ele "é" ou apenas "parecer ser" "astuto" e "cáustico"? Ficamos em dúvida se seriam esses os traços morais que presidem o seu caráter.

Contudo, a expressão "ao que parece" também atribui valor moral ao indivíduo por meio do reconhecimento social. Lembremos que o reconhecimento baseado na opinião pública (aparência) é ironicamente consagrado como forma relevante de status em Papéis avulsos. Assim, poderíamos fazer outra pergunta: Jacobina é "astuto" e "cáustico" ou parece ser assim porque ocupa uma função de "medalhão" na sociedade?

Portanto, a questão se modifica. É como se a história que "O espelho" conta sobre a prevalência da alma externa anulasse a legitimidade da questão entre "ser" e "parecer", mostrando que o primeiro verbo depende do último. Alfredo Bosi comenta esse problema, afirmando que "O espelho" arruína a concepção de eu romântico, pois, no conto, o indivíduo é necessariamente capitulado pela aparência e forma social (BOSI, 2008, p. 99-101). No entanto, Bosi comenta também o que não se simboliza na história. Assim, os embates morais do sujeito permanecem não resolvidos sob a máscara social (BOSI, 2009, p. 102-103). Nesse sentido, a capitulação de Jacobina pela aparência e pelo tipo (psicológico e social) é também insuficiente na compreensão do personagem.

Para não discutir, Jacobina rebatia com um paradoxo. Segundo ele, os querubins não controvertiam e eram a perfeição espiritual. A discussão "polida" nos homens seria uma "herança bestial" de um antigo "instinto batalhador" (ASSIS, 2008, p. 322). O argumento de Jacobina defende, no limite, a impossibilidade do debate na civilização. Conforme sua lógica, a discussão e, por consequência, as "questões de 
alta transcendência" permanecem numa arena de conflitos de fundo "bestial" (ASSIS, 2008, p. 322). Assim, um dos dados importantes de seu argumento é a "herança". Ou seja, no paradoxo de Jacobina há uma ideia de mal-estar civilizatório e de apropriação de formas do espírito na humanidade que ocorre, ao longo dos tempos, e perpetua a barbárie.

Notemos, contudo, que o argumento paradoxal de Jacobina é citado em discurso indireto pelo narrador que ironiza o discurso do personagem. Há uma tonalidade paródica do narrador em relação às explicações filosóficas de Jacobina, nesse momento do conto. Um dos movimentos de ironia que ocorre, inclusive, é que o discurso esclarecido e explicativo de Jacobina (poderíamos afirmar: totalizador) sobre a alma humana sucumbe ao impacto de sua história. A implosão irônica é articulada pelo autor implícito do conto, que está por trás da estrutura duplicada do texto e é responsável por sua arquitetura.

O interessante é que, no caso de Jacobina, os lampejos que mostram seus desvãos subjetivos e a inconsistência de suas ideias provêm da fala. A fala do personagem é relevante. Curiosamente a fala seria um elemento imprescindível também para a fundação da psicanálise uma década mais tarde. Ou seja, na psicanálise, a fala e a escuta - ambas flutuantes - instauraram um campo possível para o desenvolvimento da experiência analítica.

Já em "O espelho", se compararmos a forma como o personagem narra a sua história versus a forma como defende a teoria da alma humana, notamos um descompasso. Por meio da fala de Jacobina, percebemos faltas na dimensão subjetiva e ruínas na dimensão do discurso cientificista.

Pensemos, por exemplo, num deslize de campos semânticos que ocorre no conto. Jacobina diz que no caso dos seus vinte e cinco anos "ressalta a mais clara demonstração acerca da matéria que se trata" (ASSIS, 2008, 323). Ele também diz que "Os fatos explicarão melhor os sentimentos [...]" (ASSIS, 2008, p. 325). No entanto, durante o conto, as palavras ligadas a um campo semântico científico ou racional deslizam para o campo semântico do irracional. Jacobina promete fatos, uma experiência empírica talvez, mas sua fala logo se mostra como narração de uma história que é "experiência de vida"6 e que se encontra, portanto, no campo da memória afetiva.

\footnotetext{
${ }^{6}$ O Prof. Erwin Torralbo Gimenez no Exame de Qualificação foi quem observou a contradição entre as passagens do conto em que Jacobina diz "Os fatos explicarão melhor os sentimentos, os fatos são
} 
Assim, Jacobina é nomeado pela primeira vez apenas quando se transforma em narrador de suas memórias. Nesse momento do conto, ele ganha um nome e "reflete". O emprego do verbo "refletir"7 é interessante porque alude não apenas à ação de pensar como também às ações de "espelhar", de "expressar" e ao gesto de "influir" sobre os demais:

[...] Jacobina (assim se chamava ele) refletiu um instante, e respondeu:

- Pensando bem, talvez o senhor tenha razão.

Vai senão quando, no meio da noite, sucedeu que este casmurro usou da palavra, e não dois ou três minutos, mas trinta ou quarenta. A conversa, em seus meandros, veio a cair na natureza da alma, ponto que dividiu radicalmente os quatro amigos. Cada cabeça, cada sentença; não só o acordo, mas a mesma discussão tornou-se difícil, senão impossível, [...]. Um dos argumentadores pediu ao Jacobina alguma opinião, uma conjetura, ao menos:

- Nem conjetura, nem opinião redargüiu ele; uma ou outra pode dar lugar a dissentimento, e, como sabem, eu não discuto. Mas se querem ouvir-me calados, posso contar-Ihes um caso de minha vida, em que ressalta a mais clara demonstração acerca da matéria de que se trata. Em primeiro lugar, não há uma só alma, há duas...

- Duas?

- Nada menos de duas almas. Cada criatura humana traz duas almas consigo: uma que olha de dentro pra fora, outra que olha de fora para dentro... Espantem-se à vontade, podem ficar de boca aberta, dar de ombros, tudo; não admito réplica. Se me replicarem, acabo o charuto e vou dormir (ASSIS, 2008, p. 323).

Nesse excerto, dá-se discretamente (como na técnica plástica do chiaroscuro) a passagem do narrador em terceira pessoa para o narrador em primeira pessoa.

tudo [...]" (ASSIS, 2008, p. 325), depois diz "Tinha uma sensação inexplicável" (ASSIS, 2008, p. 326), e "[...] por uma inspiração inexplicável [...]" (ASSIS, 2008, p. 327). Informação verbal do Prof. Dr. Erwin Torralbo Gimenez na Faculdade de Filosofia, Letras e Ciências Humanas da Universidade de São Paulo, em 2012.

7 (re.fle.tir) v.

1. Provocar ou sofrer reflexão (3) [td. : Refletir luz/som/imagem/calor: São tintas que refletem a luz dos faróis e parecem acesas.] [int. : A luz da Lua refletia-se na água]

2. Fig. Deixar transparecer; EXPRIMIR; REVELAR [td. : Suas maneiras refletiam fina educação.]

3. Pensar detidamente; MEDITAR [tr. + em, sobre: Refletia nas palavras que ouvira/ sobre o problema.] [int. : Refletiu muito antes de se decidir.]

4. Ter repercussão em ou sobre. [ta. : O escândalo refletiu -se em vários estados.] [tr. + em : A crise refletiu nos escalões superiores.]

5. Ter influência sobre; incidir. [tr. + em : O gesto refletiu no irmão mais moço: Sua coragem refletia se no comportamento dos filhos.]

[F.: Do lat. reflectere.] (IDICIONÁRIO AULETE). Disponível em: http://aulete.uol.com.br/refletir. Acesso em: 10/08/2013. 
Jacobina passa a falar, com interrupções muito breves dos quatro demais. Notemos que, assim como na cena inicial do conto, as condições da enunciação do protagonista possuem característica intersticial. Lembremos: "quatro ou cinco cavalheiros"; "entre quarenta e cinqüenta anos" (ASSIS, 2008, p. 322). A fala de Jacobina é limítrofe: ela se dá "no meio da noite". O tempo da fala é igualmente aproximado: "não dois ou três minutos, mas trinta ou quarenta" (ASSIS, 2008, p. 323).

A expressão que se emprega é que Jacobina "usa da palavra". "Usar da palavra" pode significar falar como verbo intransitivo, ou seja, um gesto excepcional para um personagem calado. Assim, Jacobina, ao falar, começa a se desprender da primeira caracterização típica que Ihe foi atribuída. Contudo, ele também "usa da palavra" no sentido manipulador do verbal. Ou melhor, Jacobina apresenta sua fala como frágil a qualquer interrupção. No entanto, trata-se de um subterfúgio. Por se apresentar vulnerável, a fala de Jacobina impõe-se aos outros, alienando-os no momento da escuta.

No momento inicial de sua fala, Jacobina defende a teoria das duas almas humanas: a exterior e a interior. O conto ainda mantém o tom de paródia em relação ao discurso metafísico. A alma exterior é exemplificada por meio de representações oscilantes do desejo e seus mais variados objetos. Muitos deles representam status social. Em contraposição, muito pouco se diz da alma interior.

É interessante que em "Um esqueleto" (1875), conto avulso de Machado de Assis, publicado originalmente no Jornal das famílias, haja uma tensão similar entre a moldura do texto e a história narrada. Na repetição de algumas frases, notamos uma espécie de retomada desse conto de 1875 em "O espelho", anos mais tarde. Assim, lemos na abertura de "Um esqueleto":

Eram dez ou doze rapazes. Falavam de artes, letras e política. Alguma anedota vinha de quando em quando temperar a seriedade da conversa. Deus me perdoe! parece que até se fizeram alguns trocadilhos.

O mar batia perto na praia solitária... estilo de meditação em prosa. Mas nenhum dos convivas fazia caso do mar. Da noite também não, que era feia e ameaçava chuva. É provável que se a chuva caísse ninguém desse por ela, tão entretidos estavam todos em discutir os diferentes sistemas políticos, os méritos de um artista ou de um escritor, ou simplesmente em rir de uma pilhéria intercalada a tempo. 
Aconteceu no meio da noite que um dos convivas falou na beleza da língua alemã. Outro conviva concordou com o primeiro a respeito das vantagens dela, dizendo que a aprendera com o dr. Belém.

- Não conhecem o doutor Belém? - perguntou ele.

- Não - responderam todos (ASSIS, 2008, p. 1359).

O conviva que conhecia o dr. Belém era Alberto. De forma semelhante a como ocorre em "O espelho", ele assume o lugar de narrador do conto. Ele chora, pois o dr. Belém tinha sido seu amigo. Assim, o personagem-narrador instiga emoção e curiosidade nos ouvintes e diz que vai contar a história do esqueleto. Segundo o narrador em terceira pessoa de "Um esqueleto", a ambiência da moldura do conto estava em "pleno Hoffmann" (ASSIS, 2008, p. 1360). Dessa forma, Alberto começa a narrar uma história insólita que dialoga com o gênero de horror, mas não o pratica plenamente. Pensemos, por exemplo, que no caso de "O espelho", a história de Jacobina dialoga com o fantástico, mas não desenvolve o gênero.

Assim como em "O espelho", no fim da história de Alberto sobre o dr. Belém e o esqueleto, os ouvintes encontram-se atônitos. Então, o personagem-narrador declara a seguinte provocação:

- Ele [o dr. Belém], doido? - disse Alberto. - Um doido seria efetivamente se porventura esse homem tivesse existido. Mas o doutor Belém não existiu nunca, eu quis apenas fazer apetite para tomar chá. Mandem vir o chá.

É inútil dizer o efeito desta declaração (ASSIS, 2008, p. 1371 [grifo meu]).

O término deste conto machadiano não é tão vertiginoso quanto o término de "O espelho", pois as explicações encontram-se às claras para o leitor. No entanto, há possibilidade para o estabelecimento de pontes, a exemplo do que ocorre na relação entre Ressurreição (1872) e Dom Casmurro (1899). No primeiro romance, o narrador não deixa dúvidas quanto à fidelidade da heroína Lívia. Dessa forma, evidências no texto levam o leitor a dirigir o foco para a pessoa moral de Felix, que é atormentado pelo ciúme, entre outras paixões. Em Dom Casmurro, muito tempo depois, retoma-se igualmente o tema do ciúme, mas a ambiguidade da trama potencializa-se linha a linha no romance.

Em "Um esqueleto", Alberto infunde emoção e medo nos seus ouvintes, ao contar o caso do esqueleto. Consideremos que o gesto de "infundir" emoções nos ouvintes (e leitores) é um ponto-chave das histórias de horror ${ }^{8}$. Contudo, no fim da

\footnotetext{
${ }^{8}$ Em "A natureza do horror", Noël Carroll aborda o gênero, enfocando, sobretudo, monstros. A teoria de Carroll destaca um elemento fundamental do horror que é não por acaso o efeito de
} 
história, ele quebra a ilusão da narrativa e pede chistosamente uma bebida, que é também de "infusão", um chá.

"Um esqueleto" possui uma moldura em que dez ou doze rapazes discutem "artes, letras e política" (ASSIS, 2008, p. 1359). O narrador simula emoções de medo e repulsa para seus ouvintes, ao contar uma história rocambolesca que dialoga com o horror. O problema de induzir emoções nos ouvintes por meio da narração de um caso e depois revelar a história como embuste coloca-se em sentido oposto a uma discussão polida sobre "artes, letras e política" (ASSIS, 2008, p. 1359), pois traz à tona questionamentos sobre verossimilhança e sobre recepção literária. Assim, a história contada por Alberto contrasta ironicamente com a moldura do conto.

No caso posterior de "O espelho", a história de Jacobina toca nas bordas do Real e propõe uma concepção de sujeito não metafísica ou "essencialista", mas sim materialista e baseada na alteridade. Portanto, a história de "O espelho" também estabelece uma relação irônica com a moldura do conto, na qual há inicialmente uma "sala ruidosa de física e metafísica" (ASSIS, 2008, p. 324).

Contudo, no texto de Papéis avulsos, a ironia se encontra articulada também no nível da própria moldura. A desaparição final do narrador, que é "inexplicável", corrobora o descompasso existente entre a enunciação de explicações totalizadoras e cientificistas sobre as duas almas humanas versus a narração de sensações inexplicáveis e desvãos do sujeito.

A teoria de Jacobina afirma que o indivíduo depende tanto da alma interna, quanto da alma externa: "Está claro que o ofício dessa segunda alma é transmitir a vida, como a primeira; as duas completam o homem, que é, metafisicamente falando, uma laranja" (ASSIS, 2008, p. 323). A explicação inicial de Jacobina segue

\footnotetext{
"espelhamento" (CARROLL, 2000, p. 34). Desde o artigo de Freud, na verdade, o efeito de espelhamento aparece como algo da ordem do estranho. Em especial, Freud narra episódios de estranhamento quando nos defrontamos com nossa própria imagem de forma inesperada (FREUD, 1987, p. 309). Carroll, por sua vez, afirma que nas narrativas de horror, as reações dos personagens orientam a reação do público. Assim, o enfoque em arrepios, náuseas, paralisia, gritos e repugnância em personagens que são vitimas do horror sugerem o espelhamento do medo nos leitores ou nos espectadores. Portanto, a noção de efeito e a infusão de emoção no público são elementos-chave do gênero. Esse é outro motivo que me leva a estabelecer pontes entre "Um esqueleto" e "O espelho", embora pese uma diferença vertical entre os dois contos. Em "Um esqueleto", o espelhamento como ponto-chave do gênero de horror é colocado como questão central que se relaciona à representação literária e à recepção do ouvinte/leitor. No conto da década de 1870, encena-se como espelhar emoção nos ouvintes para que depois essas emoções sejam quebradas e mostradas como "ilusórias". No conto de 1882, movimento semelhante ocorre. Contudo, o grau de ambiguidade é muito maior. Ademais, em "O espelho", o espelhamento não é apenas um efeito visado no leitor, como também está presente na forma e na temática do conto.
} 
em registro explicativo, modalizado, contudo, pelo tom paródico. No entanto, logo após a exposição de Jacobina sobre as duas almas humanas, lemos a seguinte afirmação do narrador:

Os quatro companheiros, ansiosos de ouvir o caso prometido, esqueceram a controvérsia. Santa curiosidade! tu não és só a alma da civilização, és também o pomo da concórdia, fruta divina, de outro sabor que não aquele da mitologia (ASSIS, 2008, p. 324).

A preparação dos ouvintes guarda semelhança com "Um esqueleto", pois nele também se mostra como os personagens adotam uma postura para ouvir a narração da história, o que contribui para o estabelecimento de uma moldura no conto. Também é notável o comentário do narrador em terceira pessoa sobre a curiosidade como "alma da civilização" e "pomo da concórdia" (ASSIS, 2008, p. 324). Creio que o comentário relaciona-se à defesa de Jacobina das duas almas, que formam metafisicamente uma laranja.

Podemos perguntar primeiramente por que o narrador em terceira pessoa diz "alma" no singular. Trata-se da alma externa ou da alma interna apenas? Ou se trata de um impasse à teoria da alma dupla? Assim, notamos, por exemplo, desde o início, que o subtítulo do conto desmente a teoria de Jacobina e emprega a palavra no singular: "esboço de uma nova teoria da alma humana" (ASSIS, 2008, p. 322).

Outra questão que podemos formular é a contraposição entre "pomo da concórdia" e a "laranja" de cunho metafísico. O "pomo da concórdia" parodia o clássico "pomo da discórdia". Segundo o narrador, ele não tem um sabor como o da fruta mitológica. Creio que o pomo apresenta humoristicamente um dos nós de "O espelho", relacionando-se à componente do desejo e da alteridade implicada no desejo, pois o pomo da concórdia é uma alcunha para a curiosidade dos ouvintes. Os quatro personagens unem-se apenas após o desejo de ouvir a história (que é a história de outro).

Existe o rebaixamento paródico de um elemento clássico. Não se trata de um pomo mitológico, pois o mundo épico já não existe. Trata-se de um pomo que visa contrariamente à concórdia, que é motivada pelo desejo. O pomo da concórdia não presta tributo à beleza de deusas, mas se rebaixa ao interesse individual num mundo movido pela forma social. Não se trata de concórdia como valor complementar da discórdia, mas sim da concórdia como signo irônico que assinala rebaixamento de valores. 
Assim, o pomo da concórdia é uma espécie de fruta complementar à laranja metafísica. Por um lado, a laranja da teoria de Jacobina ilustra a alma dupla humana, mas não se sustenta como imagem diante dos impasses da história do narrador-personagem. Por outro lado, o pomo da concórdia, inscrito pela voz do narrador em terceira pessoa, faz referência à dinâmica do desejo, que se encontra em jogo no conto. Ou seja, a sala de ouvintes apenas abandona a controvérsia em função do interesse pessoal que se alça à condição de interesse comum.

José Miguel Wisnik interpretou o conto "O espelho" à luz da teoria lacaniana do estádio do espelho (WISNIK, informação verbal) ${ }^{9}$. Segundo Wisnik, o conto de Machado propõe ironicamente o "esboço de uma teoria da alma humana" que se mostra como movimento a contrapelo do estádio de espelho lacaniano (WISNIK, informação verbal) ${ }^{10}$. Resumindo parcialmente a interpretação de Wisnik, trata-se do seguinte contraste: se na teoria lacaniana, o estádio de espelho orienta a constituição do sujeito, no conto de Machado de Assis, a ausência do olhar do outro desestrutura a constituição subjetiva. Assim, o conto narra um processo de implosão subjetiva que é oposto (simétrico) à formação de um "[eu]" tal como ela ocorre no estádio de espelho.

A psicanálise lacaniana lançou-se, entre outros problemas, sobre a constituição do sujeito. Na teoria do estádio de espelho, Lacan aborda essa fase como formadora da função do "[eu]"11, sujeito do inconsciente. O estádio do espelho trata do momento em que o bebê começa a ter percepção de sua imagem, ou melhor, da imagem de seu corpo refletida no espelho. Essa imagem ao mesmo tempo acusa a insuficiência motora do infans (que é ainda um feixe desconexo de sensações) e antecipa sua forma "ortopédica", rígida. No artigo de Lacan, lemos:

A assunção jubilatória de sua imagem especular por esse ser ainda mergulhado na impotência motora e na dependência da amamentação que é o filhote do homem nesse estágio de infans parecer-nos-á pois manifestar, numa situação exemplar, a matriz simbólica em que o [eu] se precipita numa forma primordial, antes de se objetivar na dialética da identificação

\footnotetext{
${ }^{9}$ Informação verbal de José Miguel Wisnik na palestra "No encontro dos espelhos de Machado e Rosa: Lacan, Koyré e Henry Corbin" no III Colóquio de Literatura e Psicanálise (DTLCC, DLCV) na Faculdade de Filosofia, Letras e Ciências Humanas da Universidade de São Paulo, em 01/10/2012.

10 Idem.

${ }^{11}$ Lemos no título do artigo "O estádio de espelho como formador da função do eu tal como nos é revelada na experiência psicanalítica". Em nota, lemos que o "eu" do título é tradução de Je = [eu], sujeito do inconsciente (LACAN, 1998, p. 96).
} 
com o outro e antes que a linguagem Ihe restitua, no universal, sua função de sujeito.

Essa forma, aliás, mais deveria ser designada por [eu]-ideal, se quiséssemos reintroduzi-la num registro conhecido, no sentido em que ela será também a origem das identificações secundárias, cujas funções reconhecemos pela expressão funções de normalização libidinal. Mas o ponto importante é que essa forma situa a instância do $e u$, desde antes de sua determinação social, numa linha de ficção, para sempre irredutível para o indivíduo isolado - ou melhor, que só se unirá assintoticamente ao devir do sujeito, qualquer que seja o sucesso das sínteses dialéticas pelas quais ele tenha que resolver, na condição de [eu], sua discordância de sua própria realidade.

Pois a forma total do corpo pela qual o sujeito antecipa numa miragem a maturação de sua potência só Ihe é dada como Gestalt, isto é, numa exterioridade em que decerto essa forma é mais constituinte do que constituída, mas em que, acima de tudo, ela lhe aparece num relevo de estatura que a congela e numa simetria que a inverte, em oposição à turbulência de movimentos com que ele experimenta animá-la. Assim, essa Gestalt, cuja pregnância deve ser considerada como ligada à espécie, embora seu estilo motor seja ainda irreconhecível, simboliza, por esses dois aspectos de seu surgimento, a permanência mental do [eu], ao mesmo tempo que prefigura sua destinação alienante; é também prenhe das correspondências que unem o [eu] à estátua em que o homem se projeta $\mathrm{e}$ aos fantasmas que o dominam, ao autômato, enfim, no qual tende a se consumar, numa relação ambígua, o mundo de sua fabricação (LACAN, 1998, p. 97-98).

Portanto, o estádio do espelho antecede e dá origem à constituição do sujeito e às identificações secundárias. Ademais, o estádio do espelho impõe "a permanência mental do [eu]", sujeito do inconsciente, e sua "destinação alienante" (LACAN, 1998, p. 98).

Nesse sentido, José Miguel Wisnik lê o artigo de Lacan, segundo o seguinte processo de subjetivação: ele parte do "nenhum", o estado em que o bebê evidencia sua prematuração; passa pelo "dois", no momento em que o bebê reconhece sua imagem como um duplo, um outro no espelho; chegando, por fim, ao "um" (WISNIK, informação verbal) ${ }^{12}$. O "um" se dá na passagem do momento narcisista para o momento posterior de inserção social e realiza-se por meio da constituição do sujeito. Portanto, a constituição do sujeito é um destino, não um ponto de partida. No

\footnotetext{
${ }^{12}$ Op. cit.
} 
entanto, segundo a leitura lacaniana, a constituição do "um" encontra-se infinitamente assombrada pela reminiscência do duplo que um dia lhe antecedeu.

A defesa de José Miguel Wisnik na palestra "No encontro dos espelhos de Machado e Rosa: Lacan, Koyré e Henry Corbin" (2012) ${ }^{13}$ é que em "O espelho" de Machado de Assis ocorre um movimento a contrapelo em relação ao processo defendido pela teoria da psicanálise lacaniana. Jacobina se apresenta primeiramente como um. Depois, ele conta a história de seu duplo, o alferes, quando tinha vinte e cinco anos e foi obliterado por seu status social. Num dos pontos altos do conto, Jacobina se vê, no entanto, como "nenhum", "sombra de sombra" (ASSIS, 2008, p. 327).

A condição alienada do sujeito e a característica alienante do desejo marcam presença no conto "O espelho". Quando Jacobina começa a contar a história de alferes, por exemplo, ele fala primeiramente da nomeação do posto e de sua mãe. "Chamava-me o seu alferes", diz Jacobina sobre ela (ASSIS, 2008, p. 324). Depois, ele menciona o "desgosto" de terceiros, citando o "choro e ranger de dentes, como na Escritura" (ASSIS, 2008, p. 324). Ou seja, o desgosto de terceiros possui também relação com o olhar do outro: inveja e "mau olhado". Assim Jacobina diz: "Lembrame alguns rapazes, que se davam comigo, e passaram a olhar-me de revés, durante algum tempo" (ASSIS, 2008, p. 324). Contudo, Jacobina narra também a admiração dos outros e como ela, no fim, mostrou-se adversa.

Assim, na abertura do caso, há um indivíduo que passa a ocupar uma função por ter sido "nomeado" para ela. Com esse episódio, a mãe também nomeia Jacobina como "seu" alferes. A menção da inveja ampara-se na Escritura. Ou seja, ao invés de enfrentado, o olhar estranho do invejoso é mediado pelo imaginário da tradição. Portanto, no começo da história de alferes, tanto a ideia de "nomeação", quanto o "olhar" dos outros são relevantes. Assim é que Jacobina vai para um sítio distante. O pórtico de ser visto como alferes pela mãe e pela vila leva-o a outro lugar:

Vai então uma das minhas tias, D. Marcolina, viúva do Capitão Peçanha, que morava a muitas léguas da vila, num sítio escuso e solitário, desejou ver-me, e pediu que fosse ter com ela e levasse a farda. Fui, acompanhado de um pajem, que daí a dias tornou à vila, porque a tia Marcolina apenas me pilhou no sítio, escreveu a minha mãe dizendo que não me soltava

\footnotetext{
${ }^{13}$ Idem.
} 
antes de um mês, pelo menos. E abraçava-me. Chamava-me também o seu alferes (ASSIS, 2008, p. 324).

O nome da tia Marcolina ecoa o som do nome de Jacobina. Também é curioso o nome do tio morto, Capitão Peçanha, que lembra "peçonha". Dessa forma, não apenas Jacobina descreve um sítio escuso, solitário ${ }^{14}$, como também apresenta indicações sutis que prenunciam a manifestação do duplo por meio de identificações secundárias que se dão de forma sorrateira.

Assim, a tia Marcolina "pilha" Jacobina. "Pilhar"15 é um verbo que pode significar "roubar" algo de outras pessoas e "ser acometido por". A palavra também tem relação com a conquista inesperada de cargos. A tia viúva passa a ser uma espécie de mãe vigária para o recém-alferes, que é de certa forma, recém-nascido numa determinada condição social.

Contudo, a posição vigária resvala para o duplo. Além da duplicação sonora (no eco dos nomes Jacobina e Marcolina) e de uma duplicação da figura materna, a tia empresta ao personagem o objeto que, por excelência, relaciona-se ao duplo, o espelho:

Se thes disser que o entusiasmo da tia Marcolina chegou ao ponto de mandar por no meu quarto um grande espelho, obra rica e magnífica, que destoava do resto da casa, cuja mobília era modesta e simples... Era um espelho que the dera a madrinha, e que esta herdara da mãe, que o comprara a uma das fidalgas vindas em 1808 com a corte de dom João VI.

\footnotetext{
${ }^{14}$ Em parágrafo posterior, o conto "O espelho" cita o conto Barba Azul. Creio que a descrição da ambiência do sítio como "escuso" e "solitário" também mantém diálogo com o conto tradicional. Ademais, a tia Marcolina alinha-se à descrição de um personagem violento como o Barba Azul. Como a moça do conto de fadas, Jacobina cai numa tentação que se, para aquela, residia na posse das chaves, para Jacobina, reside no espelho e no consequente investimento que o personagem confere à sua imagem alienada. ${ }^{15}$ (pi./har) v.

1. Apoderar-se, de modo fraudulento, do que pertence a outrem; ROUBAR [td.: $O$ menino pilhou revistas na banca.]

2. Adornar-se do bem alheio, de modo violento; SAQUEAR [td.: Os manifestantes pilharam supermercados.]

3. Fig. Ser acometido por. [td. : Pilhou uma gripe.]

4. Aparecer inesperadamente diante de; surpreender ou ser surpreendido (em certa condição ou estado). [td. : O policial pilhou o bandido.] [tdp. : A mãe pilhou o filho absorto em seus estudos.]

5. Conseguir algo; OBTER [td. : pilhar um cargo.]

6. Achar-se em ou conseguir chegar a (determinado lugar ou estado). [tp.: A mãe morreu, e Rosa pilhou -se rica.] [int.: Depois de esbanjar a riqueza, pilhou -se na miséria.] [ta.: Quando se pilharam em casa, as crianças ficaram tranquilas.]

[F.: Do it. pigliare, deriv. do lat. * piliare 'enterrar como uma pilastra, empilhar'. Hom./Par.: pilha $(s)$ (fl.), pilha (s) (sf. [pl.]); pilharia(s) (fl.), pilharia(s) (sf.[pl.]).] (IDICIONÁRIO AULETE). Disponível em: http://aulete.uol.com.br/pilhar. Acesso em: 10/08/2013.
} 
Não sei o que havia nisso de verdade; era a tradição [...] (ASSIS, 2008, p. 324).

O espelho continua a refletir a condição alienada do sujeito. Nele aparece novamente a ideia de herança. O espelho é uma herança familiar de origem nobre, assim como, para Jacobina, a discussão era uma herança do instinto batalhador. A articulação no conto entre "estranho" e "familiar" (unheimlich) ${ }^{16}$ - conceito que Freud elaboraria mais tarde - é impressionante. Segundo o argumento de Jacobina, a barbárie é simultaneamente estranha e familiar porque longamente recalcada. $O$ espelho evoca algo de familiar em função da herança, mas igualmente algo de estranho em função do duplo.

O duplo é um dos elementos de "estranho familiar" freudiano porque traz de volta a ideia recalcada da imortalidade e, portanto, o medo relativo à mortalidade. $\mathrm{O}$ psicanalista Otto Rank investigou o duplo, concluindo que ele foi criado como uma defesa contra a morte, que é oriunda do amor narcísico. Duplicar-se seria uma forma de se crer imortal ou de garantir a continuação do eu. Posteriormente, no entanto, com superstições generalizadas, o duplo resultaria justamente no efeito reverso, já que por ter uma vez expressado a crença na imortalidade traria de volta a ideia mesma da morte (RANK, 19-?, p. 114).

Assim, no conto, há uma manifestação do duplo quando Jacobina primeiramente sofre uma capitulação cômica de si pelo tipo alferes. O jovem Joãozinho torna-se "outro". Ou seja, Jacobina se transforma em seu duplo. Contudo, a sombra logo ativa o terror. O duplo se transforma num diabo (RANK, 19-?) (RODRIGUES, 2003). Jacobina cai num desvão, quando sozinho, e persegue sua sombra que fugiu com o olhar de terceiros. Ao mesmo tempo, ele é perseguido por ela, no sentido de que dela depende para se constituir.

Por um lado, Jacobina é de fato "pilhado" pelos que o olham. Por outro, ele se constitui como hoje compreenderíamos a constituição do sujeito, segundo a teoria psicanalítica, em que o [eu] depende da imagem especular de outro para se formar (LACAN, 1998, p. 100-102). Assim, como o sujeito é destino e não princípio, apenas após o verbo e a instauração de um desejo por meio da alteridade, dá-se sua constituição.

\footnotetext{
${ }^{16}$ O "estranho familiar" é, como na citação de Schelling, "tudo o que deveria ter permanecido secreto e oculto, mas veio à luz". Ou seja, o elemento que um dia foi íntimo, tendo sido depois longamente recalcado (Freud, 1987, p. 282).
} 
Com a doença da filha da tia Marcolina, Jacobina é deixado só por ela, pelo tio Peçanha e, por fim, pelos escravos. A humanidade dos escravos é abordada de forma chocante no conto. Creio que a passagem se dá com o mesmo tom de banalização do mal que é desenvolvido em "Pai contra mãe", por exemplo. Assim, quando se encontra com os escravos, Jacobina faz pouco caso do olhar deles. No entanto, apenas quando eles estão ausentes, Jacobina reconhece-lhes a humanidade ${ }^{17}$.

$\mathrm{Na}$ solidão absoluta, Jacobina relata o horror de ter a alma exterior em desaparição, sumida com os outros. O ponto crítico de fragmentação é ver-se no espelho tradicional (o espelho da tradição) com a reprodução de sua imagem esgarçada:

Convém dizer-Ihes que desde que ficara só, não olhara uma só vez para o espelho. Não era abstenção deliberada, não tinha motivo; era um impulso inconsciente, um receio de achar-me um e dois, ao mesmo tempo naquela casa solitária, e se tal explicação é verdadeira, nada prova melhor a contradição humana, porque no fim de oito dias, deu-me na veneta olhar no espelho com o fim justamente de achar-me dois. Olhei e recuei. O próprio espelho parecia conjurado com o resto do universo; não me estampou a figura nítida e inteira, mas vaga, esfumada, difusa, sombra de sombra. A realidade das leis físicas não permite negar que o espelho reproduziu-me textualmente, com os mesmos contornos e feições; assim deve ter sido. Mas tal não foi a minha sensação (ASSIS, 2008, p. 327).

Jacobina espera ver-se como indivíduo no espelho e até como duplo. No entanto, é no nada que cai. Ele não se vê. O jogo do duplo o anulara. Apenas com a retomada da farda e na autocontemplação no espelho afidalgado e colonial é que Jacobina se reconstitui:

Vesti-a, aprontei-me de todo; e como estava defronte do espelho, levantei os olhos e... não Ihes digo nada; o vidro reproduziu então a figura integral; nenhuma linha de menos, nenhum contorno diverso; era eu mesmo, o alferes, que achava enfim, a alma exterior. Essa alma ausente com a dona do sítio, dispersa e fugidia com os escravos [...] (ASSIS, 2008: 328).

Jacobina falara antes de "impulso inconsciente", "contradição humana" e de vestir a farda "por uma inspiração inexplicável" (ASSIS, 2008, p. 327). Ao longo do

17 Quando o personagem está com os escravos diz primeiramente: "Era a alma exterior que se reduzia; estava limitada a alguns espíritos boçais" (ASSIS, 2008, p. 325). Após a fuga deles, Jacobina diz, no entanto: "Nenhum fôlego humano. Corri a casa toda, a senzala, tudo, nada, ninguém, um molequinho que fosse" (ASSIS, 2008, p. 326). 
conto, portanto, percebemos o investimento do sujeito em ilusões identitárias rígidas que são contrapostas à presença de motivações sinistras que atuam na composição do personagem.

$\mathrm{Na}$ esteira da interpretação de José Miguel Wisnik, gostaria de focalizar a reflexão sobre o problema da composição de personagens em Machado de Assis. Assim, se retomarmos o costume retórico dos caracteres praticado por Machado, observaremos, por vezes, o trajeto de um personagem que abandona a caracterização típica rumo à singularidade subjetiva e à intimidade psicológica. No caso de "O espelho", essa intimidade desenrola-se pela autoanálise do horror que está relacionado a uma falta subjetiva e ao excesso de investimento em ilusões identitárias.

A constituição do sujeito lacaniana parte igualmente da identificação com tipos ideais. Contudo, ela cai, da mesma forma, na cisão e na falta, pois o desejo mostra-se como alienante, dado que é estruturado necessariamente na relação com terceiros e em espelhamentos, e como negativo já que antecipa ao sujeito o que nele falta (SAFATLE, 2007, p. 26-34).

Pensemos, portanto, no duplo, na cisão e na falta, primeiramente, no nível do personagem e, depois, no âmbito da arquitetura narrativa em "O espelho". Jacobina constitui-se passando pelo duplo, ou seja, pelo espelho (a imagem e o olhar de outros em que se espelha). Contudo, há nele um dado de cisão porque a formação de seu desejo é alienante e denuncia-o em sua falta.

$\mathrm{Na}$ arquitetura do conto, reproduz-se, por sua vez, o caminho do duplo à cisão e à falta. Pois dupla é a estrutura narrativa do texto: há dois narradores, dois espaços, dois tempos, dois tipos de receptores, os ouvintes e os leitores. No entanto, o truncamento final do texto, que se dá com a saída abrupta de Jacobina, leva a uma forma de representação propositadamente cindida.

Assim, a teoria totalizadora das almas humanas de Jacobina não se sustenta. Ademais, por meio da cisão final no foco narrativo, os ouvintes (e nós, leitores) somos denunciados igualmente em nossa condição alienada. Com a desaparição do narrador, encontramo-nos sem o espelho identitário da narração do conto que amparava nosso tempo, preenchendo-o imaginariamente. Não por acaso o célebre ensaio de Augusto Meyer sobre o "O espelho" parte justamente da narração da experiência do próprio crítico e poeta enquanto leitor desamparado do conto. 
Neste capítulo, teci considerações sobre a questão moral em Machado de Assis, sobre a composição de personagens machadianos e, por fim, sobre "O espelho". O conto de 1882 é paradigmático porque coloca em xeque noções de identidade, de representação e recepção literária, além de enfocar processos de subjetivação enquanto tema na narrativa. Nos próximo capítulo, passarei, portanto, à análise dos contos machadianos selecionados. 


\section{PARTE II}


"Nos olhos que pestanejaram à dissimulada sagacidade, nos olhos a grande tendência à rapina". Clarice Lispector 
1. Dois contos da década de 1870: "Ponto de vista (Quem desdenha...)" (1873) e “O sainete" (1875)

\section{1}

Os contos da chamada primeira fase da obra machadiana foram recolhidos em dois volumes: Contos fluminenses (1870) e Histórias da meia-noite (1873). Há também muitos títulos avulsos por volta dos anos 1860 e 70 . Neste capítulo abordarei dois contos da década de 70: "Ponto de vista (Quem desdenha...)", de 1873, que foi publicado pela primeira vez no Jornal das famílias, tendo integrado posteriormente a coletânea Histórias da meia-noite; e "O sainete", de 1875, conto avulso, publicado no periódico A Época, sob o pseudônimo Manassés.

Para desenvolver a leitura dos dois contos, tenho em mente ideias apontadas anteriormente como o problema das motivações dos personagens, mas também o desconhecimento que os personagens têm de si, percebendo-se, em algum ponto da narrativa, diferentes de como se declaravam.

Outra ideia que tenho em perspectiva para a abordagem desses dois contos da década de 1870 provém da interpretação literária e psicanalítica desenvolvida por Cleusa Rios P. Passos a respeito de obra posterior, Dom Casmurro. Trata-se da forma como a fala do agregado José Dias interpreta e revela saberes inconscientes ao menino Bento no capítulo "A denúncia", o que terá desdobramentos ao longo do romance. Isto é, penso na forma como a fala de terceiros desengatilha no sujeito a busca pelo saber de seu próprio desejo, conforme analisou Passos (2009, p. 35-42).

Assim, abordarei esses contos que, como muitos outros da primeira fase, giram tipicamente em torno do casamento. Os objetivos são, portanto: perceber como se desenvolvem as motivações da protagonista Raquel, de "Ponto de vista (Quem desdenha...)", e da viúva Eulália, de "O sainete", em relação aos seus pretendentes; como essas motivações se dão de forma contraditória; e como a fala de terceiros envolve-se com o desejo das personagens.

Alfredo Bosi, analisando o conjunto de contos de Machado de Assis, cita como um grande número desses textos, em especial, os contos anteriores a Papéis avulsos (1882), obedeceu às convenções em voga:

Quem faz uma antologia prefere excluir a maioria dessas últimas, sem dúvida menos sugestivas esteticamente; mas o analista não pode omitir 0 
fato: Machado foi também um escritor afeito às praticas de estilo das revistas familiares do tempo, principalmente nas décadas de 1860 e 70.0 jovem contista exercia-se na convenção estilística das leitoras de folhetins, em que os chavões idealizantes mascaravam uma conduta de classe perfeitamente utilitária (BOSI, 2007, p. 75).

Bosi considera os primeiros contos como "histórias de suspeita e engano", uma forma de "pré-história da máscara" cujo uso se tornaria corriqueiro na obra de Machado de Assis, apenas a partir das Memórias Póstumas de Brás Cubas. No entanto, Bosi percebe que o delineamento da máscara como elemento narrativo machadiano já ganhava substância maior na coletânea Histórias da meia-noite ${ }^{18}$ em comparação à primeira coletânea, que havia sido publicada apenas três anos antes.

Outro ponto analisado por Bosi nesses contos é a desigualdade do status social e como ela pode ser superada pelo matrimônio ou patrimônio, temas que estão em pauta nessas narrativas e que possuem relação estreita com a dissimulação:

Subjetivamente, o narrador acentua a composição necessária da máscara na pessoa do pretendente; e, como correlato mais provável, os sentimentos de decepção que o beneficiador acabará experimentando quando a máscara já não for tão necessária ao beneficiado e, por detrás dela, se divisar a ingratidão ou mesmo a traição (BOSI, 2007, p. 77).

Veremos, em especial, como os temas do casamento e do engano - tanto no sentido de autoengano, quanto no sentido de dissimulação - desenvolvem-se em "Ponto de vista (Quem desdenha...)" e em "O sainete".

O primeiro conto se apresenta no gênero epistolar, com cartas trocadas primeiramente entre Raquel, que está na corte, e Luísa, que está em Juiz de Fora; e, mais para o fim, entre o par romântico Alberto e Raquel. Não existe o recurso do narrador e o conto se apresenta de forma dramática e dialógica como o romance epistolar dos séculos 18 e 19, havendo a presença de lugares-comuns da prosa de ficção estabelecidos pelo romantismo.

Existem, contudo, momentos inusitados no conto que entremostram rupturas na protagonista Raquel em relação justamente à escolha no matrimônio. Nesses momentos, em "Ponto de vista (Quem desdenha...)", o logro (palavra cara ao ensaio bosiano) é deslocado para conflitos internos à protagonista, em vez de se desenrolar

\footnotetext{
18 "O narrador das Histórias da meia-noite já está em trânsito para um "tempo" moral em que o que se julgaria cálculo frio ou cinismo (segundo a concepção de Alencar, por exemplo) começa a eleger-se como prática do cotidiano até mesmo no coração das relações primárias" (BOSI, 2007, p. 80).
} 
numa história de traição propriamente ou de ser colocado como interesse venal apenas. Interesse há, mas o que está nas entrelinhas das cartas é o interesse de Raquel em se casar e em não ser enganada (embora ela engane a si mesma e dissimule em sua comunicação).

A primeira carta do conto, datada de 5 de outubro, é de Raquel para Luisa $P$. e nela se apresentam personagens e situação. A destinatária Luísa, que se casou e mora na província, é melhor amiga de Raquel, que é solteira, fala dos pais e mora na corte. O primeiro assunto da carta são as encomendas que Raquel espera de Luísa. Outro assunto que aparece no começo é o "portador". Raquel comenta também sobre o recolhimento do pai, a doença da mãe e tem expectativas de que a amiga esteja grávida: "E olhe que perco muito; porque, além de ir ver a minha melhor amiga, iria ao mesmo tempo verificar se é verdade que ainda não tem esperanças de nenê. Alguém me diz que sim. Por que nega você isso?" (ASSIS, 2008, p. 223).

A segunda carta, datada de 15 de outubro, toca no tema do casamento já no primeiro parágrafo, por via indireta, falando do marido de Luísa. O segundo parágrafo retoma o tema das encomendas e do portador. Já no terceiro parágrafo, a alusão ao casamento é direta.

A postura de Raquel nas cartas parece inquirir a amiga. Assim, Raquel pede e espera diversas coisas de Luísa. Dessa forma, a espera também surge como tema relevante no conto. Raquel pergunta à amiga sobre o portador, sobre uma gravidez e sobre cartas - elementos pelos quais anseia. Já nessa cadeia de significantes, podemos analisar as motivações de Raquel. A escrita trai a protagonista por revelar informações que fogem de seu controle, além de tomar parte na constituição da própria personagem por meio do desenvolvimento de um estilo.

Dessa forma, simples detalhes entre as amigas podem ser expandidos em significado. As primeiras frases do conto, por exemplo, estão em posição de destaque e podem ser analisadas de forma especial:

Não me dirá a quem entregou você as encomendas que the pedi? Na sua carta vem mal escrito o nome do portador, e até hoje nem sombra dele, quem quer que seja. Será o Luis? (ASSIS, 2008, p. 223)

Perguntar sobre o portador na abertura do conto pode significar justamente perguntar sobre um homem de confiança. O desejo de Raquel de saber quem é o portador abre margem para a pergunta ser genericamente interpretada como a 
pergunta sobre a identidade de um homem que ela quer descobrir. Ou seja, em termos amplos, podemos interpretar a indagação de Raquel como indicação do desejo um pretendente.

$\mathrm{Na}$ segunda carta, por exemplo, podemos perceber mais uma vez a impaciência da protagonista em relação ao portador, já que as encomendas chegariam no dia seguinte:

Vieram as encomendas logo no dia seguinte da última carta. E que quer você que eu the mande? Tenho aqui uns figurinos recebidos ontem, mas não há portador. Se puder arranjar algum por estes dias irá também um romance que me trouxeram esta semana. Chama-se Ruth. Conhece? (ASSIS, 2008, p. 223)

Novamente a ideia do portador aparece, mas dessa vez ligada aos significantes "figurino" e "romance". Raquel sente falta de um portador e gostaria de enviar figurinos e um romance. Ou melhor, a ausência do portador significa justamente a impossibilidade de enviar tanto os figurinos, os moldes de roupas que esperam para ser executados, quanto o romance à espera de ser lido.

Esse trecho reafirma a interpretação da ansiedade em relação ao portador como uma indicação da busca de Raquel por um pretendente, pois dele a protagonista depende tanto para passar adiante o "figurino", palavra que pode ser interpretada como status, quanto para passar adiante o "romance", significante que alude ao amor romântico. Em suma, os dois significantes, apesar de na carta terem como significado detalhes triviais, indicam, de forma espectral, a espera de alguém que possibilite o matrimônio.

O romance que Raquel cita, Ruth, de Elizabeth Gaskell, trata da história de uma mulher "decaída" na era vitoriana, que passa por diversas provações por ter tido um filho ilegítimo. Ademais, no emprego dos dois nomes no conto, o da protagonista Raquel e o da obra, Ruth, há também a referência intertextual discreta aos nomes bíblicos.

Raquel é uma personagem bíblica relembrada por ter sido traída pela ganância do pai, mas também por ter sido a esposa preferida de Jacó. Em razão da infertilidade, Raquel foi associada igualmente ao ciúme e à impaciência (BÍBLIA, 1988, p. 35-38). Ruth, por sua vez, foi uma personagem-símbolo da submissão e da lealdade, por ter se convertido em Israel, ao acompanhar Naomi, e por ter sido 
ancestral de $\operatorname{Davi}^{19}$. As referências remetem, portanto, à história de mulheres envolvidas com a temática patriarcal do casamento e da maternidade.

Voltando ao terceiro parágrafo da carta número II, a questão do casamento surge finalmente de forma explícita. Raquel escreve:

A Mariquinhas Rocha vai casar. Que pena! Tão bonitinha, tão boa, tão criança, vai casar... com um sujeito velho! E não é só isto: casa-se por amor. Eu duvidei de semelhante coisa; mas todos dizem que tanto o pai como os mais parentes procuraram dissuadi-la de semelhante projeto; ela porém insistiu de maneira que ninguém mais se lhe opôs (ASSIS, 2008, p. 223).

Logo em seguida, lemos o trecho em que, pela primeira vez, Raquel menciona Alberto, seu futuro par:

Antes, mil vezes antes, casasse ela com o filho do noivo; esse sim, é um rapaz digno de merecer uma moça como ela. Dizem que é um bandoleiro dos quatro costados; mas você sabe que eu não creio em bandoleiros. Quando uma pessoa quer vence o coração mais versátil deste mundo (ASSIS, 2008, p. 223-224).

A partir da carta de 15 de outubro, portanto, Luísa "denuncia" Raquel em sua paixão por Alberto. Entre a troca de cartas, não temos as palavras da amiga Luísa, mas apenas a reação de Raquel na quarta carta do conto, a de 30 de outubro:

Muito velhaca é você. Então porque Ihe falei duas ou três vezes no rapaz, imagina logo que estou apaixonada por ele? Papai nestes casos costuma dizer que é falta de lógica. Eu digo que é falta de amizade. [...]

Não, Luísa, eu nada sinto por esse moço, a quem conheço de poucos dias. Falei nele algumas vezes por comparação com o pai; se eu estivesse disposta a casar-me, certamente que preferia o moço ao velho. Mas é só isto e nada mais (ASSIS, 2008, p. 224).

Toda a construção de discurso de Raquel aponta no sentido da "denúncia" da amiga: os elogios a Alberto; a menção a ele como personagem bandoleiro; e, logo em seguida, a possibilidade de vencer os corações versáteis como expressão do desejo nascente de vencer um deles. Também Raquel se coloca no lugar de

\footnotetext{
${ }^{19}$ Ruth demonstra sua lealdade a Noemi e sua obediência à conversão: "Disse, porém Ruth: Não me instes para que te deixe, e me obrigue a não seguir-te; porque aonde quer que fores, irei eu, e onde quer que pousares ali pousarei eu; o teu povo é o meu povo, o teu Deus é o meu Deus" (BÍBLIA, 1988, p. 287-288). Assim, a conclusão da história de Ruth é o casamento com Boaz e a existência de descendentes: "Todo o povo que estava na porta, e os anciãos, disseram: Somos testemunhas; o Senhor faça a esta mulher, que entra na tua casa, como a Raquel e como a Lia, que ambas edificaram a casa de Israel" (BÍBLIA, 1988, p. 290).
} 
Mariquinhas e, nessa posição, escolhe Alberto. Outro dado é que Raquel comenta a aprovação de seu pai em relação a Mariquinhas:

Papai muito aprovou a escolha dela; faz-lhe muitos elogios como pessoa de juízo, e chegou a dizer que eu devia fazer o mesmo. Que lhe parece? Eu, se tivesse de seguir algum exemplo, seguia o da minha Luísa; essa sim é que teve dedo para escolher... Não mostre esta carta a seu marido; é capaz de rebentar de vaidade (ASSIS, 2008, p. 224).

A menção do exemplo do pai traz ares de insinuação edípica ${ }^{20}$. Ou seja, Mariquinhas Rocha, a menina caracterizada como melancólica, que é obstinada já no sobrenome, casa-se com um homem velho, que poderia ser seu pai. Assim, Raquel deveria fazer o mesmo segundo a fala paterna. No entanto, é Luísa que Raquel escolhe como mentora. Nessa relação de amizade, portanto, a interpretação que Luísa opera das intenções da amiga são muito influentes e, de fato, as sugestões que Luísa faz sobre Alberto terão desdobramentos.

Ademais, estabelece-se a partir de Raquel para Luísa uma espécie de deslocamento da figura materna. Assim, Raquel teme ou recusa os julgamentos de Luísa, mas sem deixar de admirá-la, como está patente no elogio ao marido. Lembremos, por exemplo, das diversas e ansiosas demandas de Raquel a Luísa: que a última lhe diga o nome do portador; que lhe escreva cartas grandes, não bilhetinhos; que pense na amiga, não no marido; que the mande um portador; que visite a corte; que tenha um nenê.

As conversas com Luísa adquirem uma dinâmica com uma figura materna vicária $^{21}$. Portanto, a dinâmica estabelecida configura-se com admiração e rivalidade simultâneas. Assim, Raquel tanto recusa o que Luísa interpreta de suas motivações, quanto adere à leitura do desejo proposta pela amiga, noivando, no fim do conto, com o "bandoleiro dos quatro costados", Alberto.

Nos "Romances familiares", de Freud, o psicanalista cita as fantasias comuns de substituição de pais na vida infantil, mas antes como uma forma de vingança em

\footnotetext{
${ }^{20}$ Uma das primeiras defesas do complexo de Édipo foi inserida por Freud em $A$ interpretação dos sonhos em 1900: "Essa suposição é confirmada, com uma certeza que não deixa margem a dúvidas, no caso dos psiconeuróticos, quando sujeitos à análise. Com eles aprendemos que os desejos sexuais de uma criança - se é que, em seu estágio embrionário, eles mereçam ser chamados assim - despertam muito cedo, e que o primeiro amor da menina é por seu pai, enquanto os primeiros desejos infantis dos meninos são pela sua mãe. Por conseguinte, o pai se transforma num rival perturbador para o menino, e a mãe, para a menina; e já demonstrei, no caso dos irmãos e irmãs, com que facilidade esses sentimentos podem levar a um desejo de morte. Também os pais dão mostras, em geral, da parcialidade sexual: [...]" (FREUD, Sigmund, 2001, p. 258).

${ }^{21}$ Raquel dirige-se à Luísa em certo ponto pelo provérbio "ensinar padre-nosso ao vigário" (ASSIS, 2008, p. 230).
} 
relação aos pais originais do que como desprezo efetivo. A vingança, no caso, alimenta-se da negligência que alguma vez a criança sentiu ou imaginou sentir. As fantasias variam desde a substituição por pais melhores à imaginação de casos de traição e ilegitimidade dos filhos e irmãos. Freud assim conclui:

$\mathrm{Na}$ verdade, todo esse esforço para substituir o pai verdadeiro por um que Ihe é superior nada mais é do que a expressão da saudade que a criança tem dos dias felizes do passado, quando o pai parecia o mais nobre dos homens, e a mãe a mais linda e amável das mulheres. [...] $O$ estudo dos sonhos nos fornece uma contribuição interessante ao assunto. Da interpretação dos mesmos concluímos que mesmo em anos posteriores, se o Imperador e a Imperatriz aparecem em sonhos, tais nobres personagens representam o pai e a mãe do sonhador. Assim, a supervalorização dos pais pela criança sobrevive também nos sonhos de adultos normais (FREUD, 1976, p. 246-247).

Raquel coloca-se, por exemplo, numa posição oposta à de Luísa, como expresso na carta de 27 de novembro, quando a amiga da província está finalmente grávida. Assim, além de considerar como calúnia a alusão que Luísa havia feito de que Raquel e Alberto namoravam, a protagonista afirma:

A nossa divergência tem natural explicação. Eu sou uma moça solteira, cheia de caraminholas, sonhos, ambições e poesia; você já é uma dona de casa, esposa tranqüila e feliz, mãe de família dentro de pouco tempo; vê a coisa por outro prisma (ASSIS, 2008, p. 226).

Nesse sentido, podemos recorrer justamente à fonte de provérbios inscritos no conto como chaves de leitura. O título é "Ponto de vista (Quem desdenha...)" no qual há, portanto, alusão ao provérbio "quem desdenha quer comprar", desde o início. Também Raquel, ao escrever à Luísa, cita outro adágio: "Eu podia agora fazer-lhe uma dissertação a respeito do amor; mas retraio a pena por me lembrar que iria ensinar padre-nosso ao vigário" (ASSIS, 2008, p. 230).

Ponto de vista no conto quer dizer a divergência de opiniões. Assim, o título adquire relação com a polifonia do conto, pois no mínimo três vozes diferentes estão em evidência no texto, a partir da correspondência trocada entre três "pontos de vista" diferentes: o de Luísa, o de Raquel e o de Alberto. Ou seja, há desigualdade de funções narrativas entre uma mulher casada e futura mãe, uma mulher solteira e um homem solteiro.

Contudo, "ponto de vista" sugere, para além da desigualdade entre os personagens, uma forma de acesso à desigualdade dentro de uma personagem 
apenas, que é Raquel. Ou melhor, de um ponto de vista externo, Luísa, numa espécie de triangulação, pode entrever as motivações que Raquel tenta encobrir, para além do desdém superficial do amado, que chama atenção justamente pela ênfase, assim como no adágio que diz "quem desdenha quer comprar". Nesse sentido, torna-se relevante também a inscrição do provérbio do vigário. Raquel desloca para a figura de Luísa uma função de autoridade, como se a última fosse sua mãe, ou conselheira vigária, que pode ajudá-la na interpretação de si.

Luísa, mãe vicária (como o vigário do padre-nosso), na tentativa de ler as cartas da amiga, lê também suas intenções ${ }^{22}$. A leitura depende de uma atenção à seleção dos assuntos (mesmo os mais banais), ao encadeamento deles e à tonalidade nas cartas de Raquel. Ponto de vista, no conto, funciona como o lugar de onde vem um olhar. Não se trata de objetividade, mas sim de uma subjetividade formada a partir do olhar de outrem. Trata-se de um olhar angulado porque originário de um lugar que é diferente do próprio sujeito.

Raquel, como boa ouvinte da missa do vigário, depois de ser sugestionada por Luísa, reconhece-se diferente em relação a Alberto e investe no romance. A partir desse primeiro engano na narrativa, que desestrutura a forma estereotipada como a protagonista se vê, ela aprende a dissimulação que exercerá, mais para o fim do conto, tanto em relação a Luísa, quanto em relação a Alberto. Assim, Raquel continua negando à amiga que ama Alberto e ao pretendente finge indiferença.

Luísa adverte Raquel da dissimulação, por exemplo, quando em carta de 15 de janeiro, avisa que vai à corte:

[...] Ver-nos-emos, enfim depois de alguns meses de separação. Escrevo apenas para Ihe dar esta notícia que você há de estimar decerto.

\footnotetext{
${ }^{22}$ A ideia do olhar da mãe como uma leitura que engendra a constituição do desejo na criança foi abordada pela psicanalista e crítica literária Lucia Serrano Pereira em Um narrador incerto entre 0 estranho e o familiar, estudo que aborda Dom Casmurro, romance no qual o tema do olhar oblíquo é de suma importância. Pereira recorre a Bergès e Balbo: "Há certas mães, segundo Bergès, que, em relação ao corpo de seus filhos, não olhariam obliquamente, mas sim diretamente, procurando então "adivinhar" o que se passa ali. De outra maneira, um olhar oblíquo, o que ele vai permitir é algo como uma "leitura", relaciona-se aqui um olhar em alguma medida "sublime" na relação com o oblíquo" (PEREIRA, 2004 p. 65). Lucia Serrano Pereira relaciona essa interpretação angulada do desejo com o mito de Perseu, no qual a Medusa representa o inconsciente, instância à qual nunca temos acesso por via direta, necessitando, portanto, sempre de algum viés para poder tocar-lhe: "Se lembramos o mito de Perseu e Medusa, temos a indicação de que se o herói olhasse para a górgona diretamente, assim como todos os outros, sucumbiria, transformado em pedra. Seria o olhar de frente o que convocaria, de alguma maneira, o estranho. Esse olhar sem mediação, que pode produzir a irrupção do real no imaginário. Para enfrentá-la ele precisa de um olhar de lado, vê a imagem refletida, então tem algo do especular, mas é ao mesmo tempo angulado, o que lhe permite salvar-se" (PEREIRA, 2004, p. 67).
} 
E ao mesmo tempo o meu fim é preveni-la, a fim de que procure disfarçar na presença aquilo que me disfarça no papel (ASSIS, 2008, p. 228).

Ademais, em carta de 8 de fevereiro, Alberto implora a Raquel:

Perdoe-me a audácia; peço-Ihe de joelhos uma resposta que os seus olhos teimam em não me dar. Não lhe digo no papel o que sinto; não o poderia exprimir cabalmente. Mas o seu espírito há de ter compreendido o que se passa no meu coração, há de ter lido no meu rosto aquilo que eu nunca me atreveria a dizer de viva voz (ASSIS, 2008, p. 230).

Reparemos também que o discurso de Alberto toca no tema da obliqüidade necessária para a interpretação dos desejos. Ou seja, ainda que repleta do chavão romântico, a fala de Alberto reconhece que precisa de um desvio, uma modulação escrita, no caso, para ter acesso e revelar um conteúdo que cegaria, se fosse abordado diretamente. O seu amor é apresentado como de costume no melodrama, em que não há palavras para a descrição fiel dos sentimentos. Contudo, ainda assim, o personagem tenta revelá-lo, contornando-o pelas bordas e pedindo à amada uma interpretação de seu rosto. A resposta afirmativa de Raquel é dada antes do dia 8 de março (ou no dia), conforme a data da segunda carta de Alberto.

Portanto, há dois aspectos de logro no conto relativos à percepção de Raquel e à sua constituição como personagem. Num primeiro momento, Raquel deixa que suas palavras escapem-Ihe, ao escrever livremente, e dá sinais para que a amiga leia nela o desejo de casamento justamente com o homem que desdenha. Já num segundo momento, a personagem esconde suas motivações e dissimula para outros personagens.

Dessa forma, como já mencionado, há a relevância do ponto de vista (que é ironicamente subjetivo) no conto, pois Raquel cai em autoengano. Um terceiro que é próximo ao sujeito vê sua situação de outro ângulo e pode interpretá-la. Assim, a partir de seu "ponto de vista", Luísa lança provocações a Raquel, sua amiga.

Raquel é uma personagem que se forma, portanto, tendo em vista o desejo que o outro lê nela. Ou seja, o desejo que o outro interpreta e comunica-lhe. As motivações da personagem estão em pauta e têm grande relevância para a estrutura do conto. Assim, o conto pode ser lido como uma história epistolar sobre um noivado, mas também como uma história sobre as metamorfoses que se dão no ponto de vista de Raquel.

Em momentos posteriores, Raquel, que se forma a partir do logro de si mesma, aprende a dissimular - e este é o segundo tipo de logro presente no conto. 
Assim, no fim do texto, quando se lhe propõe o casamento, Raquel esconde na carta o nome do noivo, que era justamente o bandoleiro dos quatro costados descrito no início:

XXVII

D. LUÍSA A D. RAQUEL

Juiz de Fora, 22 de abril

Que cabeça! disse tudo menos o nome do noivo!

Luísa

XXVIII

D. RAQUEL A D. LUÍSA

Corte, 27 de abril

Tem razão; sou uma cabeça no ar. Mas a felicidade explica ou desculpa tudo. O meu noivo é o dr. Alberto.

Raquel

XXIX

D. LUÍSA A D. RAQUEL

Juiz de fora, $1^{\circ}$ de maio

?!!!

Luísa (ASSIS, 2008, p. 234).

O adágio "Quem desdenha quer comprar" aponta também para o aspecto comercial do consórcio. Aliás, no conto aparece uma expressão recorrente também em Senhora, de Alencar ${ }^{23}$. No título há apenas a inscrição da frase "quem desdenha", entre parênteses, suprimindo a característica venal do matrimônio, deixando-a, portanto, subentendida. Raquel chega a criticar em carta de 30 de outubro outro pretendente que frequentava sua casa pelo motivo único de que era rica (ASSIS, 2008, p. 225).

Contudo, o engano articulado pelo interesse no patrimônio por meio de casamento ou de herança, rastreado nos contos machadianos por Alfredo Bosi, ganha em "Ponto de vista (Quem desdenha...)" uma espécie de fechamento. Ou

\footnotetext{
${ }^{23}$ No banco de dados da página Machado de Assis.net, encontramos fontes da expressão céu "todo recamado de estrelas": "A imagem, de gosto acentuadamente romântico, é recorrente na literatura do século XIX. À guisa de exemplo, uma passagem de Alexandre Herculano (1810-1877) e outra de José de Alencar (1829-1877): "[...] enquanto o exército godo acabava de transpor o rio e vibrava milhares de frechas perdidas para o lado onde os capilhares alvíssimos dos árabes branquejavam à luz duvidosa do céu recamado de estrelas." (Eurico, o presbítero, cap. 9). Em Alencar: "A noite estava plácida e serena. No céu recamado de estrelas, a brisa acariciava uns frocos de nuvens alvas como a penugem das garças." (Senhora, parte 3, capítulo 1)". Disponível em: http://www.machadodeassis.net/dtb resposta contos.asp?Selromance $=\&$ Selconto $=227 \& S e l c a m p o=1$

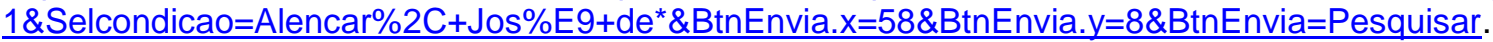
Aceso em 10/02/13.
} 
seja, nenhum dos personagens é enganado dessa maneira e o noivado tem final feliz. Assim, há uma diferença de tratamento quanto ao tema do engano pela história, pois este é deslocado para operar em função das motivações e desejos do mundo interno de Raquel.

Dessa forma, o conto aborda um episódio sobre uma mudança na protagonista. Ou seja, apesar de constantemente voluntariosa, a Raquel impaciente da primeira carta não é exatamente a Raquel dissimulada das últimas missivas. Para tanto, ela conta com o diálogo da amiga (mãe vicária) e sai do autoengano. Assim, com a aprendizagem do uso da máscara nas relações familiares, ela passa a agir e a dissimular em função de seus desejos.

\section{2}

"O sainete" guarda pontos de semelhança e de diferença com "Ponto de vista (Quem desdenha...)". A diferença mais evidente, a princípio, é a desigualdade de status entre as protagonistas de cada conto no que concerne ao matrimônio. Enquanto Raquel inicia o conto como a jovem solteira, idealista e "cheia de caraminholas" 24 , segundo sua própria descrição, a "viúva Seixas" leva a marca do casamento passado, ajudando a compor a galeria de viúvas machadianas.

Um problema que seria posteriormente desdobrado de forma complexa e longa em laiá Garcia é semelhante ao que observamos em "O sainete" em relação à escolha do título. Assim, em laiá Garcia, o romance por diversas vezes narra preferencialmente a história de Estela à história de laiá ${ }^{25}$. Em "O sainete", por sua vez, a palavra do título é usada para designar uma personagem coadjuvante, Fernanda, embora a narração enfoque, em grande parte, a viúva Seixas como objeto de amor de Maciel, mas principalmente como sujeito na trama.

Assim, a viúva é uma mulher que engana, que se auto-engana e que se modifica bem como Raquel de "Ponto de vista". Nesse sentido, observemos que "Ponto de vista" é também um título que cria expectativas diversas do que ocorre na trama do conto. O conto é polifônico e trata antes das metamorfoses realizadas nas

${ }^{24}$ Cf. p. 7.

${ }^{25}$ Contudo, devemos observar que o fim do romance trata justamente da forma como laiá Garcia alcança sua ambição num casamento superior na hierarquia social, o que lhe faz valer a aprendizagem completa do uso da máscara. Nesse lance final é que laiá rouba ironicamente para si o título, enquanto Estela conserva incólume sua dignidade até o fim da trama e mesmo depois dele. Pois, a frase pungente do final "Alguma coisa escapa ao naufrágio das ilusões" refere-se, num nível mais evidente do texto, à sinceridade da coroa de flores que Estela deixara ao seu falecido marido (ASSIS, 2008, p. 622). 
personagens, que se dão a partir de olhares subjetivos, do que do apego a um ponto de vista fixo.

A abertura de "O sainete" enfoca o personagem dr. Maciel. O conto propõe uma dúvida de caráter retórico, que é logo solucionada no parágrafo seguinte:

Um dos problemas que mais preocupavam a rua do Ouvidor, entre as da Quitanda e Gonçalves Dias, das duas às quatro horas da tarde, era a profunda e súbita melancolia do dr. Maciel. $\mathrm{O} d r$. Maciel tinha apenas vinte e cinco anos, idade em que geralmente se compreende melhor o Cântico dos cânticos do que as Lamentações de Jeremias. Sua índole mesma era mais propensa ao riso dos frívolos do que ao pesadume dos filósofos. Pode-se afirmar que ele preferia um dueto de grã-duquesa a um teorema geométrico, e os domingos do Prado Fluminense aos domingos da escola da Glória. Donde vinha pois a melancolia que tanto preocupava a rua do Ouvidor?

Pode o leitor coçar o nariz, à procura da explicação; a leitora não precisa desse recurso para adivinhar que o dr. Maciel ama, que "uma seta do deus alado" o feriu mesmo no centro do coração. O que a leitora não pode adivinhar, sem que eu lho diga, é que o jovem médico ama a viúva Seixas, cuja maravilhosa beleza levava após si olhos dos mais consumados pintalegretes [...] (ASSIS, 2008, 1384).

A frase inicial pinta um quadro que retrata o dr. Maciel, de uma forma irônica e cômica, como se ele fosse o próprio emblema da melancolia. Há uma desproporção da sua tristeza, que sobressai como tema mais importante da rua do Ouvidor, mas com hora marcada. O médico é apresentado metonimicamente por este estado de humor, de uma forma "enquadrada". Isto porque ele está num quarteirão do Rio de Janeiro, na famosa rua do Ouvidor, entre uma rua e outra ${ }^{26}$, e também porque está inserido num intervalo temporal, ou seja, entre as duas e as quatro horas.

Outro aspecto que contribui para a comicidade da apresentação é o uso da pergunta retórica que interpela os leitores. O cômico advém de uma contraposição tipificada entre leitoras e leitores. Ou melhor, advém da forma como o leitor implícito é representado tipologicamente, com desnível de perspicácia em relação aos gêneros: elas são mais atentas à mudança de comportamento do médico em função de uma paixão; eles possivelmente "coçam o nariz", de maneira dubitativa e um pouco ridícula. O diálogo com o leitor suposto, portanto, é ríspido. Esse diálogo

${ }^{26}$ DEBRET, Jean Baptiste. "Planta da cidade de S. Sebastião do Rio de Janeiro". In: Voyage Pittoresque e Historique au Brésil, v. 2. Paris: Firmin Didot Frères, 1835. Disponível em: http://www.brasiliana.usp.br/bbd/handle/1918/624520093. Acesso em: 11/03/13. 
torna-se ainda mais áspero para se referir à viúva Seixas. O narrador afirma que dela ninguém poderia saber, a menos que ele a evocasse. Assim, desde o início, a apresentação da viúva é diferenciada.

O começo do romance é narrado de forma entusiástica, ainda com referências a lugares-comuns da tradição do romantismo (como a languidez e imagens hiperbólicas, por exemplo), quando a viúva convida o médico a visitá-la de forma mais reclusa, aos sábados. Contudo, apesar do início promissor para o dr. Maciel, os episódios seguintes logo se tornariam decepcionantes:

E não obstante aquele intróito, o dr. Maciel andava triste, abatido, desconsolado. A razão era que a viúva, depois de tão amáveis preliminares, não cuidou mais das condições em que seria celebrado um tratado conjugal. No fim de cinco ou seis sábados, cujas horas eram polidamente bocejadas a duo, a viúva adoeceu semanalmente naquele dia, e o jovem médico teve de contentar-se com a turbamulta das quintas-feiras (ASSIS, 2008, p. 1384).

Interessante na primeira visita de Maciel à viúva, contudo, é outra apresentação detalhada da personagem, a partir do motivo dos olhos verdes, que é recorrente na obra de Machado de Assis.

Em "Miss Dollar", conto de abertura de Contos fluminenses, por exemplo, os olhos verdes de Margarida são percebidos como agourentos ${ }^{27}$ por Mendonça, que tenta precaver-se contra a amada em função da cor de seus olhos ${ }^{28}$. A precaução do personagem é uma superstição oriunda de referência literária a Gonçalves Dias, no poema "Olhos verdes", em que o eu-lírico é levado à morte em vida por um par de olhos dessa cor (DIAS, 1851, p. 68-70).

Também nas Falenas (1870) encontra-se o poema "Musa dos olhos verdes", alegoria da esperança, construída a partir de contrastes (ASSIS, 1870, p. 19). Na estrofe final, por exemplo, o eu-lírico, ao qual se atribui melancolia, faz um pedido à esperança: "Dentro de mim, noite escura e fria/ Melancolica chora; Rompe estas sombras que o meu ser povôão;/ Musa, sê tu a aurora!" (ASSIS, 1870, 20).

Já no conto "O sainete", lemos a seguinte descrição da viúva Seixas:

[...] tinha cravado nele um par de olhos, não negros, não azuis, não castanhos, mas dessa rara cor, que os homens atribuem à mais duradoura

\footnotetext{
${ }^{27}$ Os olhos são uma das imagens listadas por Freud como forma de expressão do "estranho familiar" (FREUD, 1976, p. 273-315).

28 "A falar a verdade, o único defeito que Mendonça lhe achou foi a cor dos olhos, não porque a cor fosse feia, mas porque ele tinha prevenção contra os olhos verdes. A prevenção cumpre dizê-lo era mais literária que outras coisa; [...]" (ASSIS, 2008, p. 15).
} 
felicidade do coração, à esperança. Eram verdes, de um verde igual ao das folhas novas, e de uma expressão ora indolente, ora vivaz, arma de dois gumes, que ela sabia manejar como poucas (ASSIS, 2008, p. 1384).

Nesse trecho aparece também o tema do desprezo ${ }^{29}$, ou melhor, de um desprezo ambíguo por parte da personagem, assim como em "Miss Dollar", em que Margarida é uma viúva atraente, ao mesmo tempo em que é inacessível, e em "Olhos verdes", de Gonçalves Dias, em que se lê o seguinte sobre as esmeraldas do par de olhos: "diz uma - vida; outra - morte", e "Davão amor sem amar!" (DIAS, 1851, p. 69-70). A esperança, portanto, é aludida enquanto martírio, condição pendular, segundo a qual, ora existe a possibilidade do amor, ora não. Ou então, enquanto condição desigual, interesse nutrido por um só lado do par romântico, enquanto o outro lado diverte-se à custa do jogo de capricho entre ceder e não ceder.

Uma diferença peculiar da viúva Seixas, contudo, consiste em ser descrita como o sujeito que maneja os olhos. Seus olhos, diferentemente da referência aos olhos em “Miss Dollar" e em "Olhos verdes”, por exemplo, não são tão vivamente destacados. Nesses textos breves da tradição, um do próprio Machado, outro de Gonçalves Dias, os olhos ganham uma boa dose de autonomia em relação ao corpo e à pessoa representada, assim como ocorre, por exemplo, no tema psicanalítico dos membros decepados, figuras do "estranho familiar" freudiano que são observáveis desde os românticos. Assim, os olhos verdes em Gonçalves Dias são apresentados por sinédoque. Já os olhos verdes de "Miss Dollar" tornam-se um agouro à parte, como se fossem um elemento dissonante em relação ao restante da figura de Margarida: "A falar a verdade, o único defeito que Mendonça lhe achou foi a cor dos olhos [...]" (ASSIS, 2008, p. 15).

$\mathrm{Na}$ descrição da viúva Seixas, no entanto, é ela quem crava os olhos e manipula-os enquanto arma ambígua. Dessa forma, no conto "O sainete", o mau agouro é deslocado de uma referência meramente supersticiosa como em "Miss Dollar", ou trágica e assustadora como em "Olhos verdes”, de Gonçalves Dias, para a ação de uma personagem enquanto sujeito que está no controle das relações interpessoais. Ou seja, o mau agouro encontra-se não mais em superstições ou em olhos que ganham autonomia, mas sim na dinâmica das relações. Nesse sentido, é

\footnotetext{
${ }^{29}$ Atente-se também para o detalhe de que quando dispensava Maciel a viúva adoecia no dia do encontro. O desprezo torna-se ainda mais significativo (assim como ainda mais ambivalente) em função de o personagem ironicamente ser médico (ASSIS, 2008, p. 1384).
} 
perceptível mais uma vez como o uso da máscara social e da dissimulação na ficção machadiana acentuava-se no decorrer da década de 70, como afirmou Bosi. Em "O sainete", portanto, a viúva Seixas é uma protagonista apresentada logo no início do conto como uma mulher que manipula (e dissimula) o olhar ao bel-prazer, diferentemente de Raquel de "O ponto de vista (Quem desdenha...)", que adquire essa habilidade no decorrer da narrativa.

O início de "O sainete", aliás, é in media res, detendo-se primeiramente sobre a melancolia do dr. Maciel, para depois retornar aos antecedentes desse sentimento, com a breve narração de como ele e a viúva Seixas conheceram-se. A ação no conto é retomada a partir de uma quinta-feira santa, portanto, fim da quaresma, dia em que Maciel tinha decidido declarar-se para a viúva. A viúva era devota, o que justificava o plano de Maciel em fazer seu apelo num período de comoção religiosa. O narrador, contudo, refere-se ironicamente à ingenuidade do personagem quanto a esse ponto:

A quinta-feira em que nos achamos é de endoenças. Não era dia próprio de recepção. Contudo, Maciel dirigiu-se a Botafogo, a fim de pôr em execução um projeto, que ele ingenuamente supunha ser fruto do mais profundo maquiavelismo, mas que eu, na minha fidelidade de historiador, devo confessar que não passava de verdadeira infantilidade. Notara ele os sentimentos religiosos da viúva; imaginou que, indo fazer-Ihe naquele dia a declaração verbal do seu amor, por meio de invocações pias, alcançaria facilmente o prêmio de seus trabalhos (ASSIS, 2008, p. 1384-1385).

Se Maciel no primeiro parágrafo é descrito pelo traço determinante das atividades e dos interesses frívolos, a descrição continua nesse sentido, ao pintar o personagem como um ingênuo. Além de ter um plano e expectativas igualmente fáceis de serem logrados, ele alimentava a ilusão de que os alcançaria sem dificuldade. Outra questão é a má interpretação de Maciel das intenções da viúva que, se era "boa devota", acreditava "alguma coisa em Deus" apenas (ASSIS, 2008, p. 1385). Assim, a viúva Seixas, em contraposição ao personagem de Maciel, continua a ser descrita como uma personagem ambígua:

Era boa devota aquela senhora de vinte e seis anos, que freqüentava as festas religiosas, comia peixe toda a quaresma, acreditava alguma coisa em Deus, pouco no diabo e nada no inferno. Não acreditando no inferno, não tinha onde meter o diabo; venceu a dificuldade, agasalhando-o no coração. O demo assim alojado fora algum tempo o nosso melancólico Maciel. A religião da viúva era mais elegante que outra coisa. Quando ela se 
confessava era sempre com algum padre moço; em compensação só se tratava com médico velho. Nunca escondeu do médico o mais íntimo defluxo, nem revelou ao padre o mais insignificante pecado (ASSIS, 2008, p. 1385).

A religião elegante pode ser lida justamente como uma religião superficial, que somente se representa nos ritos e demonstra status. Assim, segundo o narrador, a viúva "Queria alcançar por sedução a misericórdia divina" (ASSIS, 2008, p. 1385). Como não acreditava no inferno, ela era mais astuta do que crédula. $O$ dado de que guardava o diabo no coração traça ironicamente um retrato de uma personagem "pecadora", conforme o dogma católico. Sabemos que por um momento apenas o diabo foi o dr. Maciel e que em nenhum outro a viúva confessou qualquer pecado, o que pode conotar tanto a ausência deles quanto a dissimulação.

A protagonista prefere os padres moços como se desejasse a transgressão do tabu de ser "a mulher do padre". No entanto, os médicos que escolhe são os velhos, dado que se, por um lado, reafirma sua incredulidade por confiar apenas em médicos experientes, por outro, indica mais uma vez o desinteresse pelo médico moço que é Maciel.

Em suma, a descrição que o narrador faz da viúva como devota sinaliza também, no fim do parágrafo, o significado oposto, ou seja, a incredulidade e a blasfêmia. Portanto, a "fidelidade de historiador" do narrador, além de ser mais insinuante do que objetiva, é construída de forma a mostrar a infantilidade do plano de "maquiavélico" de Maciel, que pensava em apelar para os sentimentos religiosos da personagem.

Assim, a cena da declaração de amor corre desastradamente. O médico não consegue falar à viúva, que sai apressada, a pretexto de visitar sete igrejas. Quando ela entrava no carro, Maciel começava a se declarar, mas dessa fala ela ouvira apenas seu nome, "- Eulália..." (ASSIS, 2008, p. 1386):

Pobre rapaz! - dizia ela consigo - Vê-se que morre por mim. Não desgostei dele a princípio... Mas tenho eu culpa de que seja um maricas? Agora, sobretudo, com aquele ar de moleza e abatimento, é... não é nada... é uma alma de cera. Parece que vinha disposto a ser mais atrevido; mas a alma faltou-lhe com a voz, e ficou apenas com as boas intenções. Eulália! Não foi 
mau este começo. Para um coração daqueles... Mas qual! c'est le genre ennuyeux ${ }^{30}$ ! (ASSIS, 2008, p. 1386)

$\mathrm{Na}$ visita às igrejas, contudo, Eulália encontra sua amiga, a viúva Fernanda, com seu tio desembargador. Pedindo-Ihe conselhos, Fernanda se diz apaixonada por Maciel e pede ajuda de Eulália que, conforme aquela já havia observado, era amiga dele. A viúva Seixas age com surpresa e dissimulação quanto à admiração de Fernanda pelo médico. Ela fica surpresa e questiona o que Fernanda lhe fala dos atributos de Maciel. No entanto, age dissimuladamente porque esconde que o objeto da paixão do médico era ela própria. Assim, as palavras de Fernanda tocam a viúva Seixas, desestruturando sua percepção de Maciel.

O interessante, ademais, é o descentramento da percepção que a viúva tem em relação a si própria como resposta ao eco das palavras de Fernanda, pois quando retorna a casa, ela se olha no espelho da seguinte forma:

[...] Levaram-Ihe uma taça de chocolate, que ela saboreou lentamente, tranquilamente, voluptuosamente; saboreou-a e saboreou-se também a si própria, contemplando da poltrona em que estava, a sua bela imagem no espelho fronteiro. Esgotada a taça, recebeu de uma criada o seu livro de orações; e foi dali a um oratório, diante do qual com devoção se ajoelhou e rezou. Voltando ao quarto, despiu-se, meteu-se no leito, e pede-me que the cerre as cortinas; feito o quê, murmurou alegremente:

- Ora o Maciel!

E dormiu (ASSIS, 2008, p. 1387).

Eulália encerra, portanto, a quinta-feira, dia da santa ceia, com a voluptuosidade de degustar o chocolate e de se contemplar no espelho. Não parece haver nenhuma associação entre essas ações e a exclamação do nome de Maciel. No entanto, o fechamento do dia da viúva revela um primeiro descentramento de seu desejo. Antes desprezando Maciel, a viúva nessa cena faz graça da confissão feita por Fernanda. O detalhe relevante é que ela se encontra na cama, espaço de intimidade, na hora de dormir, demonstrando, portanto, não ser tão indiferente ao assunto do médico. O fato de ela se olhar no espelho com voluptuosidade, ademais, indica a abertura do desejo erótico da personagem, além de uma mudança em relação à percepção de sua própria imagem.

\footnotetext{
${ }^{30}$ A citação é originária de Voltaire: "Tous les genres sont bons sauf le genre ennuyeux". A citação encontra-se em prefácio de L'enfant prodigue (1736) e reforça o sentimento de tédio da viúva em relação a Maciel.

Disponível em: http://www.machadodeassis.net/dtb resposta contos.asp?Selromance $=\&$ Selconto $=289 \&$ Selcampo $=1$ $1 \&$ Selcondicao=Voltaire $\&$ BtnEnvia. $x=52 \& B \operatorname{BnEnvia} . y=9 \&$ BtnEnvia=Pesquisar. Acesso em: 06/03/13.
} 
Embora o conto não narre o desenrolar da trama em ordem cronológica, os próximos movimentos são os seguintes: Maciel, depois do desastre da quinta-feira, encontra-se determinado a ir clinicar em Carangola (não é necessário comentar que o narrador ridiculariza-o mais uma vez); na sexta-feira da paixão, Fernanda insiste com Eulália para que ela Ihe ajude numa aproximação a Maciel; a viúva escreve ao médico no sábado, mas o cenário se modifica, pois usando o pretexto da paixão de Fernanda para enviar a carta ao médico, os propósitos de Eulália são abalados e ela decide finalmente ceder ao amor de Maciel.

O conto desenvolve-se, assim, sobre a mudança operada no desejo da viúva Seixas. A viúva, personagem descrita, desde o início do conto, de forma ambígua, contraditória e agressiva, vacilava não só na religião, mas também no interesse por Maciel. Eulália é desestruturada em direção a uma nova conformação do desejo, o que ocorre apenas depois de ouvir a palavra de um terceiro elemento da relação, representado nesse caso pela viúva Fernanda. Assim como em "Ponto de vista", trata-se da fala de uma amiga que denuncia à protagonista um desejo que ela desconhecia.

Lembremos que o olhar em "Ponto de vista", de Histórias da meia-noite, passava pela angulação de uma mirada que vinha de fora e que modificava o olhar de Raquel. A obliquidade e os desvios que a amiga Luísa desenvolveu foram fundamentais para o acesso a conteúdos latentes na escrita de Raquel e para a transformação subjetiva da personagem.

Já em "O sainete", os desvios do olhar seguem outro caminho ou via crucis ${ }^{31}$ : começam na dissimulação, pois a viúva Seixas era senhora de seus olhos verdes, desde o início do conto; passam pela angulação de um terceiro; assim, a viúva Fernanda, com um olhar diferenciado (porque apaixonado) fornece uma mirada de Maciel que é nova para a personagem Eulália; por fim, deságuam no ciúme, na inveja e no orgulho como temas que circulam entre as personagens.

Em suma, o ponto de virada do conto dá-se apenas depois que o médico é admirado por um terceiro, pois só assim Eulália deseja roubá-lo para si. Vejamos excerto do fim do conto:

A leitora espera decerto ver casados os dois namorados e espaçada a viagem a Carangola até o fim do século. Quinze dias depois da declaração

\footnotetext{
${ }^{31}$ Lembremos que o domingo de Ressurreição também significou a ressurreição de Maciel: "[...] Com estes elementos era difícil não ter os melhores sonhos do mundo. Teve-os Maciel, e o domingo de Ressurreição também o foi para ele" (ASSIS, 2008, p. 1389).
} 
inicial Maciel deu os passos necessários ao consórcio. Não têm número os corações que estalaram de inveja ao saber da preferência da viúva Seixas. Esta pela sua parte sentia-se mais orgulhosa do que se desposasse 0 primeiro dos heróis da terra.

Donde veio este entusiasmo e que varinha mágica operou tamanha mudança no coração de Eulália? Leitora curiosa, a resposta está no título. Maciel pareceu insosso, enquanto lhe faltou o sainete de outra paixão. A viúva descobriu-Ihe os méritos com os olhos de Fernanda; e bastou vê-lo preferido para que ela o preferisse. Se me miras, me miram, era a divisa de um célebre relógio do sol. Maciel podia invertê-la: se me miram, me miras; e mostraria conhecer o coração humano - o feminino, pelo menos (ASSIS, 2008, p. 1389).

Em texto muito posterior, Melanie Klein (1957) evocou a fonte literária emblemática de Otelo para debater sobre a conceituação da inveja. Otelo foi referência central também para Machado de Assis no texto em que se aborda, de forma mais aguda, a paixão do ciúme, Dom Casmurro. A referência à tragédia do mouro de Veneza, aliás, constituiu chave de leitura para a interpretação de Helen Caldwell, que deslocou a questão da traição de Capitu para o ciúme do narradorprotagonista.

Klein enfocou a inveja em suas pesquisas clínicas. Segundo a psicanalista, o ciúme, a inveja e a voracidade estão estreitamente relacionados e surgem como pulsões de morte. Para Klein, a inveja é originária, especialmente, da relação da criança com o seio materno e das frustrações advindas dessa relação. O seio materno, na leitura kleiniana, possui um significado muito mais amplo e simbólico do que o seio físico, reverberando em manifestações do seio bom nutridor e do seio mau que priva a criança da satisfação.

Klein diferencia a inveja e o ciúme. A primeira basicamente desenrola-se entre dois sujeitos, a mãe e a criança que, em seus ataques contra o seio mau (privação), deseja a destruição de qualquer objeto bom. Já o ciúme desenvolve-se pelo menos entre três atores, pois o ciumento sente que alguém lhe priva de seu amor (KLEIN, 1991, p. 212):

[...] De acordo com o English Synonyms, de Crabb, “(...) o ciúme teme perder o que possui; a inveja sofre ao ver o outro possuir o que ela quer para si. (...) O invejoso passa mal à vista da fruição [...]." O ciúme, segundo Crabb, é "uma paixão nobre ou ignóbil, de acordo com o objeto. No primeiro caso, é emulação aguçada pelo medo. No segundo, é voracidade 
estimulada pelo medo. A inveja é sempre uma paixão vil, arrastando consigo as piores paixões" (KLEIN, 1991, p. 213).

Klein lê em Otelo a expressão do ciúme ignóbil, ou seja, o ciúme voraz que destrói seu objeto de amor. Ainda comentando a tragédia de Shakespeare, ela observa:

Shakespeare nem sempre parece diferenciar inveja de ciúme; os versos seguintes, de Otelo, mostram plenamente a significação da inveja no sentido em que aqui a defini:

"Oh beware my Lord of jealousy;

It is the green-eyed monster which doth mock

The meat it feeds on"...

Fazem-nos lembrar a expressão "morder a mão que alimenta", quase sinônimo de morder, destruir e estragar o seio (KLEIN, 1991, p. 214).

Dessa forma, em Shakespeare, referência especial para Machado de Assis no que tange à análise das paixões e dos caracteres, o ciúme (ou a inveja) é representado alegoricamente como um monstro de olhos verdes. Lembremos justamente que em "O sainete" a apresentação da viúva Seixas tem como um dos pontos-chave 0 detalhe dos olhos verdes enquanto armas de dois gumes. A referência intertextual, portanto, ecoa no conto.

A palavra inveja é mencionada textualmente em relação a Maciel, ou seja, todos os outros admiradores da viúva ficaram com inveja do médico por ele ter sido o escolhido de Eulália. A decepção da personagem Fernanda também é patente. $O$ ciúme de Eulália, contudo, encontra-se no conto, de forma mais relevante, justamente porque atua na mudança da imaginação moral da protagonista. Eulália já tivera como admirador e pretendente Maciel, mas ele se tornou "insosso" em pouco tempo, e o único fator decisivo para que a viúva assumisse o desejo por ele foi a ameaça de perdê-lo para o interesse de outra mulher.

Melanie Klein cita o ciúme como "paixão nobre", segundo o dicionário de Crabb, quando se trata de uma "emulação provocada por medo" ${ }^{32}$. Ora, o que Eulália faz ao voltar para casa e "atuar", contemplando-se na frente do espelho? O que ela faz quando disseca as palavras e confissões que the vêem da viúva Fernanda? Não se trata de uma imitação? Uma mimetização de um desejo de outrem que chega a superar o original inspirador? Aliás, a relação da viúva Seixas

\footnotetext{
${ }^{32}$ Cf. página anterior.
} 
com a religião não é também mimética, com todas as imagens, oratórios e a encenação dos ritos?

Donde veio este entusiasmo e que varinha mágica operou tamanha mudança no coração de Eulália? Leitora curiosa, a resposta está no título. Maciel pareceu insosso, enquanto the faltou o sainete de outra paixão. A viúva descobriu-Ihe os méritos com os olhos de Fernanda; e bastou vê-lo preferido para que ela o preferisse (ASSIS, 2008, p. 1389).

O sainete é um vocábulo que insinua a violência encoberta nas relações mais cotidianas e banais como as relações familiares que estão em perspectiva no conto. Confiando em Eulália, Fernanda foi simbolicamente eliminada da história, como se atuasse conforme a palavra do título. Ou seja, a personagem foi uma isca. Uma isca para um falcão voraz? Eulália, apresentada de forma ambígua e misteriosa, é também referida por seu paladar: o peixe, o chocolate e a degustação voluptuosa do doce e de sua própria imagem. Nesse sentido, ela também está relacionada à voracidade e à inveja.

Também a descrição da confissão de Fernanda toca no ponto da voracidade do discurso. A fala de Fernanda é aludida pela metáfora da "torrente". Assim, embora o narrador mencione "saciedade", temos a indicação do oposto, ou seja, do exagero:

[...] Tem-se visto muito vez guardar um segredo do coração; mas é raríssimo que, uma vez revelado, deixe de o ser até a saciedade. Fernanda escreveu e disse tudo o que sentia; sua linguagem, apaixonada e viva, era uma torrente de afeto tão volumosa que chegou talvez a alagar - a molhar pelo menos - o coração de Eulália. Esta ouviu-a a princípio com interesse, depois com indiferença, afinal com irritação (ASSIS, 2008, p. 1388).

Ademais, "sainete" quer dizer "gosto", palavra que remete à preferência e também entra no campo semântico do gustativo, do que é acessível por meio do paladar. A competição apeteceu a percepção que a viúva tinha de Maciel e fez com que ele mudasse aos olhos dela.

Nesse sentido, entra em pauta um tema machadiano recorrente que é a discussão sobre os móveis íntimos das personagens - afinal, o que os motiva? mesmo, ou principalmente, quando esses motivos são inconfessáveis. No caso da viúva Seixas, parece tratar-se do ciúme e do desejo de possuir um amor necessariamente invejável. 
Machado de Assis, no conto "O sainete", propôs uma ligação coesa entre conteúdos como ciúme, inveja e voracidade. O autor inseriu-se, de modo original, numa tradição literária preocupada com a elaboração das paixões dos caracteres, assim como podemos observar no diálogo intertextual que estabeleceu em relação a Shakespeare, ao longo de sua obra ${ }^{33}$.

Em "Ponto de vista (Quem desdenha...)", há o percurso de uma personagem que se modifica orientada pelas sugestões da amiga. A partir do que lhe escreve Luísa, Raquel muda sua percepção em relação aos outros e a si mesma. O ponto de virada da narrativa dá-se na forma de assunção do romance por parte de Raquel. Ou seja, ocorre tanto uma mudança de ponto de vista da protagonista em relação ao seu pretendente, quanto uma conquista sua em relação ao uso da dissimulação.

Já em "O sainete", como já mencionado, Eulália é uma protagonista que se configura como uma mulher mais experiente que Raquel. A viúva Seixas tem um grande domínio da arte de dissimular, aspecto observável com frequência na composição das personagens machadianas. Ainda assim, a viúva muda em relação ao seu pretendente, ao ser impulsionada pela fala de uma amiga. No entanto, entre Raquel e Luísa, embora haja algum resquício de rivalidade, há lealdade. De forma diferente, entre a viúva Seixas e a viúva Fernanda, há uma competição acirrada, que se torna o motor da inspiração do amor de Eulália pelo médico Maciel.

Guardadas as assimetrias entre os dois contos, nos dois textos, encontramos os seguintes aspectos relevantes em sua composição: o olhar; o desejo das personagens; e, por fim, o descentramento da percepção e do desejo que constitui ponto de virada da narrativa. As protagonistas não terminam o conto como o iniciam e, desde o título de ambos, há a indicação de que o assunto a ser observado será justamente uma mudança ou expansão. Assim, os títulos enunciam: "reparem, leitores, na diferença de pontos de vista e em como Raquel desdenhava em falso"; ou no segundo caso, "reparem, leitores, em como o amor da viúva Seixas precisava de um sainete para ser motivado".

O olhar, no caso, é uma via tanto de descentramento quanto de expressão das motivações das personagens. A partir de olhares externos, as protagonistas desviam seus próprios olhares, seja para uma percepção diferente da anterior, seja para disfarçar, dissimular ou para, finalmente, depois de um árduo percurso, declarar

\footnotetext{
${ }^{33}$ Cf. José Luiz Passos (2007) Machado de Assis: o romance com pessoas.
} 
seu amor. Nesse sentido, a inscrição do relógio de sol que aparece invertida em "O sainete" é reveladora: "Se me miras, me miram, era a divisa de um célebre relógio de sol. Maciel podia invertê-la: se me miram, me miras; e mostraria conhecer o coração humano - o feminino pelo menos" (ASSIS, 2008, p. 1389).

No primeiro momento, a divisa coloca em pauta uma subjetividade que se constitui a partir das relações intersubjetivas, significando o seguinte processo de subjetivação: "passo a ser inserido no mundo sob a condição de que alguém me olhe". No segundo momento, há a consideração das obliquidades e das excentricidades do desejo, pois a exemplo do caso da viúva voraz, ela só desejava mirar quem já era mirado e tinha um público ao redor de si. Lembremos que Maciel aparece no início do conto como se estivesse numa moldura, num quadro. Portanto, no momento da releitura machadiana da divisa do relógio de sol, demais paixões são englobadas à dinâmica do olhar (entre elas, o ciúme e a inveja, por exemplo). 
"Tão difícil a vida e o seu ofício". Lygia Fagundes Telles 


\section{2. "D. Benedita (Um retrato)" (1882)}

D. Benedita é o quinto conto de Papéis avulsos, coletânea de 1882. O conto foi publicado pela primeira vez em A Estação, entre abril e junho do mesmo ano. Trata-se de um conto que foi primeiramente publicado por seriação. Assim, ele é relativamente longo e divide-se em quatro capítulos.

"D. Benedita" leva como subtítulo, entre parênteses, a designação "Um retrato". Como já citado, o retrato tende à individualização, entre as diferentes modalidades da pintura moral. Ou seja, o retrato desenha personagens singulares, não se detendo sobre tipos ou personagens alegóricas. Porém, lembremos que essa divisão não é estanque. Podemos encontrar desenhos verbais que, para compor um único perfil de personagem ou de pessoa histórica, desenvolvem tanto a técnica do retrato, quanto a técnica do caráter.

No caso de "D. Benedita", uma das questões que o conto problematiza é o delineamento da figura de uma mulher singular que, de certa forma, é impossível de ser delineada. D. Benedita é uma personagem que se perde em meio aos laivos de seus anseios individuais, que são direcionados para vários lados.

A narração do conto arma-se em parte sobre a dinâmica de apreensão das linhas de D. Benedita que, logo em seguida, contradizem-se ou deixam-se escapar em função da dispersão da vontade da personagem. O narrador arma situações e tece comentários que ironizam a condição dessa senhora. O primeiro parágrafo ilustra a dinâmica de apreensão e de supressão das linhas de d. Benedita, abordando, primeiramente, a sua idade:

A coisa mais árdua do mundo, depois do ofício de governar, seria dizer a idade exata de D. Benedita. Uns davam-Ihe quarenta anos, outros quarenta e cinco, alguns trinta e seis. Um corretor de fundos descia aos vinte e nove; mas esta opinião, eivada de intenções ocultas, carecia daquele cunho de sinceridade que todos gostamos de achar nos conceitos humanos. Nem eu a cito, senão para dizer, desde logo, que $D$. Benedita foi sempre um padrão de bons costumes. A astúcia do corretor não fez mais do que indigná-la, embora momentaneamente; digo momentaneamente. Quanto às outras conjeturas, oscilando entre os trinta e seis e os quarenta e cinco, não desdiziam das feições de $\mathrm{D}$. Benedita, que eram maduramente graves e juvenilmente graciosas. Mas, se alguma coisa admira é que houvesse 
suposições neste negócio, quando bastava interrogá-la para saber a verdade verdadeira (ASSIS, 2008, p. 287).

A apresentação de ideias que se contradizem e se ajustam simultaneamente num breve intervalo de tempo é desenvolvida ao logo de todo o conto. O movimento aparece, desde o primeiro parágrafo. Assim, a primeira frase afirma no tempo condicional do modo indicativo: "A coisa mais árdua do mundo, depois do ofício de governar, seria dizer a idade exata de D. Benedita" (ASSIS, 2008, p. 287). Já a frase final do mesmo parágrafo entra em contradição com a frase inicial: "Mas, se alguma coisa admira é que houvesse suposições neste negócio, quando bastava interrogála para saber a verdade verdadeira" (ASSIS, 2008, p. 287).

Por que a coisa mais árdua do mundo seria dizer a idade exata de D. Benedita, quando bastava perguntar a ela a "verdade verdadeira"? Coloca-se em foco, na primeira frase, o problema de apreender um elemento de D. Benedita com "exatidão". Esse problema pauta a composição de toda a personagem. Em parte, evoca-se a inefabilidade do indivíduo e do sujeito, quando levada ao limite. Complementarmente, evoca-se um problema de representação literária. Ou seja, como captar "exatamente" um indivíduo na composição de um retrato verbal? Assim, “D. Benedita” problematiza o aspecto convencional da representação literária. narrador considera árdua, se não impossível, a tarefa de dizer ou representar algo "exatamente".

Contudo, a tarefa de dizer a idade de d. Benedita não aparece como "a coisa mais árdua do mundo", sendo relativizada como a segunda atividade mais tortuosa. Quanto à primeira tarefa mais árdua suscitada pelo narrador, trata-se do "ofício de governar". O ofício do governo é pautado igualmente pelo exercício da linguagem e pretende conciliar elementos em sociedade que são, no limite, inconciliáveis. Podemos interpretar que o governo é árduo em função do mal-estar inerente à civilização. Ou seja, como formulado pela psicanálise freudiana no século 20 , a constituição de uma civilização é necessariamente conflituosa, pois as demandas dos sujeitos não se encontram representadas nas normas convencionalmente instituídas pela coletividade ${ }^{34}$.

\footnotetext{
${ }^{34}$ Joel Birman, ao analisar "O sujeito no discurso freudiano" argumenta sobre como a psicanálise mostrou-se uma crítica radical da filosofia do sujeito, que é tributária, por exemplo, da filosofia de Descartes e de Leibniz. Nesse sentido, o psicanalista percebe como o conceito de pulsão em Freud impõe o mal-estar civilizatório, ao criticar o campo da representação. Pois, o conceito de pulsão sem representação exige singularidade em relação a um mundo de formas consagradas de simbolização: "Porém, a força pulsional não é absorvida totalmente pelo universo da representação, mas demanda
} 
Desdobrando a questão do governo como "a coisa mais árdua do mundo", para o caso específico de d. Benedita, contudo, pode-se interpretar que um dos ofícios mais tortuosos é o governo de si como indivíduo ou o governo de seu desejo, considerando-se uma concepção descentrada (não cartesiana) de sujeito. narrador, no fim do conto, relaciona a figura de $d$. Benedita à figura da fada "veleidade". Assim, d. Benedita é desenhada como uma personagem de veleidades, não de "desejos". Seus anseios, no conto, não são resolutos. Nascem profusamente e morrem, de forma rápida. São caprichos. Em termos psicanalíticos, poderíamos afirmar, por exemplo, que D. Benedita figura uma personagem que não se assume como sujeito de desejo.

Assim, a contradição do parágrafo inicial do conto permanece. Por que seria tão difícil dizer a idade dessa senhora, quando bastava perguntar-lhe? Por um lado, a primeira frase abre-se para questões em torno do alcance da representação literária do indivíduo na modalidade do retrato. Por outro lado, a frase diz respeito à composição formal da própria personagem d. Benedita. Isto porque o desenho de d. Benedita segue uma dinâmica de "formação supressiva" (PASTA JR., 2008), em que a personagem não se constitui formativamente. D. Benedita vaga fugazmente de objeto a objeto. Por isso, a segunda coisa mais árdua do mundo seria dizer a idade exata da senhora. Trata-se de uma observação irônica do narrador sobre a composição de uma personagem instável.

No primeiro parágrafo, quando $\mathrm{d}$. Benedita se indigna contra o corretor de fundos, esse seu gesto se dá "momentaneamente" (ASSIS, 2008, p. 287). Notemos, aliás, que o "corretor de fundos", tipo que lucra em função das especulações financeiras, é quem propõe o valor etário mais ousado a d. Benedita. A aposta da

do outro um trabalho de interpretação incessante, infinito e interminável. Com isso, o sujeito como destino é sempre um projeto inacabado, se produzindo de maneira indeterminável, se apresentando sempre como uma finitude face aos seus impasses, confrontado ao que the falta e ao que não é. Nessa figuração, seria a pulsão que desordenaria as formas estabelecidas de representação e de subjetivação, já que o mundo instituído de objetos de satisfação e de representação fica sempre aquém das exigências pulsionais. Nesse contexto, se impõem várias pontuações. Primeiro, a ideia de que o sujeito se define pelo valor do desamparo, que é a maneira de Freud se referir à finitude do sujeito, pois não existiria qualquer sistema de representações e de objetos capaz de conferir unidade e constância para as formas estabelecidas de subjetivação. Segundo, a ideia de mal-estar na civilização só agora se impõe, na medida em que, se a civilização é a garantia de um mundo alteritário e pretensamente universalista, a existência da pulsão sem representação é a exigência de singularidade face às formas consagradas de simbolização e à busca de novas possibilidades de subjetivação. Dessa maneira, o campo social seria marcado pelo intervalo entre as exigências pulsionais e as formas constituídas de subjetivação. Por isso mesmo, essa figuração do sujeito fundado na pulsão não admite uma hermenêutica, pois o que se impõe é a possibilidade de novas formas de produção do sujeito pelo contraponto aos códigos hermenêuticos estabelecidos (BIRMAN, 1997, p. 37-38). 
idade em vinte e nove contém ironia, pois o corretor quer retratá-la como jovem, mas de maneira limítrofe, entre a casa dos vinte e a casa dos trinta. Assim, o narrador menciona as intenções sedutoras do corretor como "intenções ocultas" (ASSIS, 2008, p. 287) e conforma d. Benedita como alvo de investidas de homens. De um lado, ela "foi sempre um padrão de bons costumes" (ASSIS, 2008, p. 287). De outro, sua indignação é apenas momentânea.

Nessas poucas linhas do conto, apresenta-se, portanto, uma narrativa na qual se entrevê o conflito de uma mulher, do Rio de Janeiro do século 19, em relação ao seu casamento. Contudo, os primeiros parágrafos não vão diretamente a essa informação. Ou melhor, eles contornam a questão, mas não chegam a informá-la ao leitor, de pronto. A narração se dá ambiguamente. Ou seja, narra-se sobre "a mesa da família" e "a dona da casa" (ASSIS, 2008, p. 287). Porém, quando se trata dos murmúrios em torno da idade de d. Benedita, ela é alvo das "intenções ocultas" de um corretor (ASSIS, 2008, p. 287). Considerando-se a esfera social de proprietários do século 19, poderia tratar-se de uma viúva como as demais viúvas na ficção de Machado de Assis. Contudo, este não é o caso da personagem.

O padrão dos bons costumes é imperioso, mas não deixa de abrir frestas para a possibilidade de adultério e para o erotismo. Ainda assim, não se trata de um conto sobre o adultério. Pois, a reação "momentânea" de d. Benedita ao corretor de fundos não conota apenas a sua hesitação em relação à monogamia, mas significa a veleidade que está presente na personagem, desde a sua origem. Há um deslocamento na narrativa. $O$ conto pretere a intriga do adultério (tema recorrente no século 19) e dirige-se à questão moral e a questões de constituição do sujeito que estão implicadas na composição da personagem.

Assim, para além da excessiva especulação sobre a idade da senhora, o narrador nos informa, por exemplo, que as suas feições eram "maduramente graves e juvenilmente graciosas" (ASSIS, 2008, p. 287). Como seriam essas feições, considerando-se que são descritas num campo limítrofe, que se dá pela má conciliação de opostos?

A expressão "verdade verdadeira", ademais, para aludir à franqueza de $\mathrm{d}$. Benedita quanto à sua idade, demonstra o emprego irônico do discurso indireto livre. Com frequência, no conto, o narrador emprega uma expressão que teria sido falada originalmente por ela, d. Benedita. Assim, outro gesto do narrador é o de ironizar ou depreciar o estilo de fala da personagem, em especial no que diz respeito ao uso de 
frases feitas. Ou seja, "os cumprimentos de estilo" e "as palavrinhas doces" (ASSIS, 2008, p. 292). Alguns exemplos são:

D. Benedita repete com a boca a D. Maria dos Anjos tudo o que com os olhos the tem dito: - que está encantada, que considera uma fortuna conhecê-la, que é muito simpática, muito digna, que traz os corações nos olhos, etc., etc., etc. [...] (ASSIS, 2008, p. 288)

E declarou que não, que a outra era boa, um anjo, um verdadeiro anjo; palavra que ela sublinhou com o mesmo olhar namorado, não persistente e longo, mas inquieto e repetido (ASSIS, 2008, p. 289).

[...] Outra raiva de $d$. Benedita, porque a chinela era muito galante, e foraIhe dada por uma amiga do ano passado. Um anjo, um verdadeiro anjo! [...] (ASSIS, 2008, p. 290).

D. Benedita é que não via nada; via a amiga; a feiticeira, como the chamou duas ou três vezes, - "feiticeira como ela só" (ASSIS, 2008, p. 292).

Quanto à família, era impossível ser mais amável; ao menos, a impressão que deixou na alma de D. Benedita foi intensíssima. Uso este superlativo, porque ela mesma o empregou: é um documento humano (ASSIS, 2008, p. 298).

Quanto à irmã solteira era uma flor, uma flor de cera, outra expressão de d. Benedita, que não altero com receio de entibiar a verdade (ASSIS, 2008, p. 298).

Assim, d. Benedita facilmente diria a "verdade verdadeira" de algo porque outra característica da personagem é ser falante, portando-se como uma repetidora de frases. Ademais, por meio da expressão "verdade verdadeira", D. Benedita é necessariamente contraposta ao narrador. Ou seja, enquanto o narrador reconhece que a tarefa mais árdua é a de dizer exatamente, $d$. Benedita fantasia poder dizer a "verdade verdadeira" das coisas, substancial e adjetivamente.

Contudo, a postura do narrador é também ambígua. Percebemos seus comentários irônicos, quando se explica: "Uso este superlativo, porque ela mesma o empregou: é um documento humano"; "[...] outra expressão de d. Benedita, que não altero com receio de entibiar a verdade" (ASSIS, 2008, p. 298). O "documento humano" é empregado para justificar a composição de um retrato que se quer fiel. No entanto, o uso é também irônico, pois já no primeiro parágrafo, notam-se os impasses que o narrador levanta quanto à representação literária de um indivíduo. "Com receio de entibiar a verdade" (ASSIS, 2008, p. 298) é expressão que possui o mesmo emprego. Ou seja, o narrador sabe tratar-se de ficção e de efeitos de 
discurso, mas, ao prometer uma descrição reprográfica de uma suposta verdade, ironiza as expectativas do leitor.

O leitor ou a leitora provavelmente tinham anseio por ler uma história narrativa em registro de representação romântica ou realista, literatura da moda. Considerando-se o quadro geral do conto, percebe-se, aliás, que o efeito final do texto está justamente articulado ao diálogo irônico com as expectativas do leitor. Pois toda a narração é desenvolvida de um modo que se supõe realista na representação da realidade externa. No entanto, o último parágrafo destoa do registro que se vinha desenvolvendo no conto, em função da aparição etérea de uma fada, numa janela carioca em Botafogo que se descreve de forma muito concreta, concretíssima.

Quanto à explicitação do caráter convencional da representação literária, podemos lembramo-nos, por exemplo, de que muitos dos contos de Papéis avulsos apresentam-se num registro narrativo orientado pelo absurdo. Como defendido por Ivan Teixeira, o absurdo que preside o estilo da coletânea de contos de 1882 daria continuidade ao salto experimental realizado nas Memórias Póstumas de Brás Cubas $^{35}$.

Na mesa de textos irmãos reunidos pelo pai, em Papéis avulsos, contos como "D. Benedita" e "A chinela turca" ${ }^{36}$ têm uma orientação estilística que tende à narração de registro realista. Contudo, esses contos confirmam a presença do absurdo como elemento composicional na coletânea, pois eles encenam a forma como a fantasia, o sonho, a imaginação moral e o desejo dos personagens infiltramse decisivamente nas frestas das narrativas.

Retomemos, então, a trama de "D. Benedita: (Um retrato)". Após o parágrafo inicial, a situação da família de d. Benedita é apresentada. Essa situação, aliás, possui ligação com o emprego irônico da expressão "verdade verdadeira", pois como reconhece Ivan Teixeira, d. Benedita vivia um "simulacro de casamento" (TEIXEIRA, 2005, p. XXXIV). Assim, o emprego da expressão pelo narrador é irônico.

A senhora tem dois filhos, um menino e uma moça, Eulália, mais velha, já em idade de se casar. O conto apresenta o cenário da recepção de aniversário de d.

\footnotetext{
${ }^{35}$ Conferir "Pássaro sem asas ou morte de todos os deuses: uma leitura de Papéis avulsos", de Ivan Teixeira (Apud ASSIS, 2005).

${ }^{36}$ Sobre sonho, imaginação moral e desejo inconsciente em "A chinela turca", conferir interpretações de José Luiz Passos (2007) e Lucia Serrano Pereira (2008) nos respectivos livros: Machado de Assis: o romance com pessoas; e O conto machadiano, uma experiência de vertigem: ficção e psicanálise.
} 
Benedita com a presença de "vinte ou vinte cinco" convidados. Nesse grupo, há um cônego e outra senhora que pretende casar seu filho com Eulália.

Num momento da festa, o pretendente de Eulália, Leandrinho, faz um brinde ao marido ausente de d. Benedita, o "desembargador Proença". Ou seja, D. Benedita fora abandonada pelo marido há aproximadamente dois anos, a pretexto de ele exercer o cargo no Pará, pois fora nomeado pelo ministério Zacarias, não tendo conseguido a "Relação de São Paulo ou da Bahia" (ASSIS, 2008, p. 289).

A palavra "Relação" está no conto para significar o cargo e as províncias ${ }^{37}$, mas seu emprego não deixa de ser insinuante. "Um sujeito" (ASSIS, 2008, p. 289) que se encontrava ao lado de Leandrinho explica-lhe a situação, utilizando a palavra. Há um grande teor de murmúrio no diálogo entre Leandrinho e o sujeito. Ou seja, o caso de $d$. Benedita era comentado naquele círculo social por personagens não identificados, figurados fragmentariamente. Ademais, há o deslize da palavra "Relação" para um significado velado, no momento inicial do conto, a saber, a ideia de relação conjugal.

D. Benedita "não podendo conter-se" (ASSIS, 2008, p. 288), na ocasião do brinde, retira-se chorando. Há um constrangimento total na festa, que se dissipa em algum tempo. O constrangimento é desviado pela conversação sobre amenidades, em especial sobre a "eleição do melhor doce" (ASSIS, 2008, p. 289), empreendida pelo cônego Roxo.

Assim, os personagens são apresentados no primeiro capítulo do conto. Desde o início, d. Benedita é retratada como inconstante, simultaneamente de difícil e fácil apreensão. Seu filho é praticamente ignorado. Eulália, por sua vez, surge como uma personagem que figura um contraponto à mãe, pois é caracterizada com "severidade dos modos e das feições" (ASSIS, 2008, p. 288).

A senhora Maria dos Anjos mostra-se como uma mulher que ambiciona escolher o casamento de seu filho. Ela não se comporta dispersivamente como d. Benedita, mas sim de forma atenta em função de interesses pessoais. Já Leandrinho é caracterizado como um jovem que segue a moda superficialmente,

\footnotetext{
${ }^{37} \mathrm{Na}$ banco de dados da página MachadodeAssis.net, lê-se: "O Tribunal da Relação do Império corresponde ao atual Tribunal de Justiça, órgão colegiado constituído de Juízes de segunda instância, denominados desembargadores. O primeiro tribunal surgiu no país em 1609, na Bahia, denominado-se Tribunal da Relação do Estado do Brasil. Em 1751, foi criado o Tribunal da Relação do Rio de Janeiro, tendo por jurisdição todo o território do Sul da Colônia. Posteriormente foram sendo criados outros". 
pois diz uma citação em francês, mas demonstra não ter traquejo social algum, ao levantar um problema familiar numa festa. O cônego Roxo, por fim, constitui uma autoridade vigária na casa, exercendo o papel de padre inserido numa parentela.

$\mathrm{Na}$ pintura da festa, nota-se um estilo descritivo que dialogava com o meio de publicação do texto, a revista $A$ Estação. As frivolidades sociais são elementos em pauta na comemoração do aniversário. A primeira parte do conto, portanto, apresenta um cenário que imita determinadas convenções de sociabilidade e de lazer. A cena narrativa que se encontra inserida nessa ambiência, contudo, apresenta o retrato deslizante de d. Benedita e as circunstâncias de abandono no casamento, que geram tristeza, embaraço e murmúrios.

Os problemas sugeridos mostram-se dissonantes em relação às convenções sociais. Ou seja, a inconstância de d. Benedita, a ausência do desembargador, os personagens que são orientados pelos interesses mais comezinhos etc. são nós problemáticos na cena da festa. Esses nós, por sua vez, lançam mistério na narrativa, fazendo com que a leitora queira ler aquele retrato de mulher.

Assim, ao mesmo tempo em que o conto se adapta à orientação do público leitor feminino de $A$ Estação, há um diálogo irônico com o meio de publicação. Pois o retrato de $\mathrm{d}$. Benedita esboça a figura de uma mulher não adequada em relação ao papel que the é socialmente designado como "dona da casa". Apresenta-se uma clivagem entre o status de d. Benedita como uma senhora casada e seu estado de abandono. A dinâmica que perfaz essa clivagem, no texto, é a do movimento incessante e exaustivo que vaga por diferentes "estados mentais" 38 de d. Benedita, ao longo da narrativa.

\footnotetext{
${ }^{38}$ A expressão está empregada como Wollheim a descreve em On the emotions: "Mental states are those transient events which make up the lived part of the life of the mind, or to use William James's great phrase, 'the stream of consciousness'. They occur at a time, though the duration of a mental state seldom admits of precise determination. Different mental states of the same person can be successive, or they can overlap, or they can be simultaneous. Examples of mental states are perceptions, such as hearing the dawn chorus, or seeing a constellation or stars overhead; sensations, such as pains and itches, and pangs of hunger or thirst; dreams, and daydreams; moments of despair, boredom, or lust; flashes of inspiration; recollections; images seen in the mind's eye, and tunes heard in the head; and thoughts both thoughts that we think and those uninvited thoughts which drift into the mind" (WOLLHEIM, 1999, p. 1). "Estados mentais são eventos transitórios que constituem a parte viva da mente, ou para usar a grande expressão de William James, "o fluxo de consciência". Eles ocorrem num tempo, embora a duração de um estado mental raramente admita uma determinação precisa. Diferentes estados mentais de uma mesma pessoa podem ser sucessivos, sobrepor-se ou ser simultâneos. Exemplos de estados mentais são percepções como ouvir o cantar dos pássaros no amanhecer ou ver uma constelação de estrelas sobre si; sensações como dores e comichões, o tormento da fome ou da sede; sonhos e devaneios; momentos de desespero, tédio ou luxúria; lampejos de inspiração; lembranças; imagens vistas pelos olhos da mente, e melodias ouvidas na própria cabeça; e pensamentos, tanto pensamentos que pensamos
} 
Portanto, a adaptação da temática do conto de Machado de Assis ao periódico A Estação é desenvolvida de forma irônica. O conto frustra o público leitor no que tange à expectativa que este nutre em relação a determinados registros de representação narrativa. Em adição, há a composição de um retrato feminino que é instável.

Lembremos que o diálogo irônico entre o texto literário de Machado de Assis e o meio de publicação $A$ Estação foi defendido originalmente por Ana Claudia Suriani da Silva em Machado de Assis's Philosopher or dog?: from serial to book form (SILVA, 2010). Silva analisa, por exemplo, a relação entre a descrição de elementos da moda que tendiam a uma imitação de "gosto aristocrático", no primeiro texto de Quincas Borba, publicado em A Estação, e as ilustrações da revista, que figuravam cenas aristocráticas (SILVA, 2010, p. 69-92). Nesse sentido, Quincas Borba ironiza o gosto aristocrático no Brasil, considerando-se o contexto político e econômico do país no período. Outro alvo da ironia de Quincas Borba era o desejo pelo arrivismo social, pois o desejo de ascensão é uma lógica que preside a leitura de revistas de moda (SILVA, 2012, p. 90).

A Estação, segundo Silva, era uma revista de moda precursora das revistas femininas do gênero no século 20 como Burda, Marie Claire e Vogue (SILVA, 2010, p. 42). A revista fazia parte de uma franquia internacional cujo ethos imitava o gosto francês. Contudo, a publicação era originalmente alemã: Die Modenwelt. O periódico era publicado em diversos países, tomando forma em vinte revistas e em treze línguas (SILVA, 2010, p. 39). Apesar de a publicação ser padronizada e traduzida, havia também adaptações e textos originais escritos nos diferentes contextos. Assim, por exemplo, Machado de Assis publicava no "Suplemento literário" do periódico no Brasil. A Estação circulou no país entre 1879 e 1904 (SILVA, 2010, p. 39).

Em seu estudo, Silva estabelece uma rede de implicações entre os seguintes elementos: a observação e propagação dos movimentos da moda pelo periódico $A$ Estação, que incluía não apenas vestuário, como também decoração, atividades de sociabilidade e de lazer, como a literatura; o desejo de ascensão social que motivava a leitura de revistas do tipo; a imitação do gosto e das atividades da elite; o

voluntariamente, quanto aqueles pensamentos indesejados que se impelem na mente" [tradução minha]. 
público leitor feminino; e a escrita irônica de Machado de Assis em relação ao periódico, quando da publicação de Quincas Borba (SILVA, 2010).

Nesse sentido, podemos deslocar algumas associações que Silva estabeleceu sobre a relação entre Quincas Borba e A Estação, para o caso do conto “D. Benedita”. Penso, em especial, nos excertos do livro de Silva que afirmam:

I put forward the hypothesis that the predominantly female readership of the serial was more likely to make an immediate connection between the plot of Quincas Borba and fashion, which is the main subject of A Estação. It must be clarified here that the term fashion does not only apply to the predominant trends in clothing and accessories, which are represented by new styles over a certain period of time, in line with a rhythm dictated at times by the changing season of the year. It also includes other areas of social activity, such as leisure (including reading), and the fashion of prestigious residential districts and high class professions. In Les lois de l'imitation, Gabriel Tarde distinguishes fashion from costumes. Costumes are linked to the tradition, and to the past, while fashion pays homage to the present and is guided by novelty. We shall see that the magazine A Estação paid homage not only to fashion but also to the habits of the elite [...] (SILVA, 2010, p. 3) $)^{39}$.

Founded in October 1865, the aim of the magazine Die Modenwelt was to teach housewives how to make clothes for the whole family, embroider and decorate their houses [...]. [...] not only clothing but general ornamentation and accessories were discussed (SILVA, 2010, p. 39-40) ${ }^{40}$.

No primeiro excerto, Silva reconhece a escrita de Machado de Assis como necessariamente voltada ao seu meio de publicação. Assim, ao publicar Quincas Borba, em A Estação, o estilo de Machado nesse romance considerava o público leitor do periódico, bem como o entorno das páginas da revista. Outra ideia defendida por Silva é que as mulheres leitoras notariam, no ato da leitura, a conexão proposta pelos temas do romance em relação aos temas usuais de $A$ Estação.

\footnotetext{
39 "Defendo a hipótese de que o público predominantemente feminino do periódico provavelmente faria uma conexão imediata entre a trama de Quincas Borba e a moda, que é o tema principal de $A$ Estação. Deve-se esclarecer aqui que o termo moda não se aplica apenas às tendências predominantes em roupas e acessórios, que são substituídas por novos estilos, após certo período de tempo que está alinhado a um ritmo ditado pela mudança de estações do ano. Ele também inclui outras áreas de atividade social, como o lazer (incluindo a leitura), e a moda dos bairros prestigiados e das profissões de alta classe. Em Les lois de l'imitation, Gabriel Tarde diferencia a moda dos costumes. Os costumes estão relacionados à tradição e ao passado, enquanto a moda presta homenagem ao presente e orienta-se pela novidade. Veremos que a revista $A$ Estação dedicava-se não apenas à moda, como também aos hábitos da elite, inclusive à filantropia" [tradução minha].

40 "Fundada em outubro de 1865, o objetivo da revista Die Modenwelt era ensinar donas de casa a fazer roupas para toda a família, bordar e decorar a casa [...]. [...] não apenas roupas, mas ornamentação em geral e acessórios eram discutidos" [tradução minha].
} 
Já o segundo excerto supracitado afirma que um dos principais objetivos editorias da revista, desde 1865, era o de ditar moda a donas de casa. Nesse sentido, o ethos da revista estava intimamente ligado à construção de um tipo ideal de mulher de uma determinada esfera social. A construção desse perfil passaria pela imposição de consumo, costumes, roupas, produtos, atividades, formas de decorar a casa, etc.

Pensando nas ideias desenvolvidas pelo estudo de Silva em relação ao conto “D. Benedita”, podemos supor que, de um lado, o público de leitoras reconheceria os temas de seu interesse no texto literário de Machado de Assis, que traçava o perfil de uma mulher casada e dona de casa. De outro lado, no entanto, o conto propõe um impasse. Pois D. Benedita é uma personagem que está longe de conformar-se a um papel modelar de mulher que é socialmente instituído.

$\mathrm{Na}$ cena da festa, a relação é visível, pois narram-se os gestos de sociabilidade dos presentes, a forma como cortar o peru, os doces, etc., no entanto, há um ruído quanto à ausência do marido da senhora. No segundo capítulo do conto, a vida familiar de d. Benedita como "dona da casa" torna-se ainda mais explícita. O capítulo narra um dia no cotidiano da família:

D. Benedita levantou-se, no dia seguinte, com a idéia de escrever uma carta ao marido, uma longa carta em que the narrasse a festa da véspera, nomeasse os convivas e os pratos, descrevesse a recepção noturna, e, principalmente, desse notícia das novas relações com d. Maria dos Anjos. A mala fechava-se às duas horas da tarde, D. Benedita acordara às nove, e, não morando longe (morava no Campo da Aclamação), um escravo levaria a carta ao correio muito a tempo. Demais, chovia; D. Benedita arredou a cortina da janela, deu com os vidros molhados; era uma chuvinha teimosa, o céu estava todo brochado de uma cor pardo escura, malhada de grossas nuvens negras. Ao longe, viu flutuar e voar o pano que cobria o balaio que uma preta levava à cabeça: concluiu que ventava. Magnífico dia para não sair, e, portanto, escrever uma carta, duas cartas, todas as cartas de uma esposa ao marido ausente. Ninguém viria tentá-la (ASSIS, 2008, p. 290).

O parágrafo diz, por exemplo, que d. Benedita não morava longe. Ela morava no Campo da Aclamação e um escravo poderia levar a carta a tempo. Assim, d. Benedita não morava longe do centro do Rio, mas a senhora morava longe do marido. A frase ecoa também o seu contrário, no sentido de que a afirmativa se aplicaria, caso o referencial fosse outro. 
O dia que amanhece com uma "chuvinha teimosa" é racionalizado como motivo para que a personagem não saia de casa e escreva para o marido. A preta, por sua vez, aparece figurada como um elemento da paisagem. A personificação da chuva como teimosa é interessante porque, nesse parágrafo, o narrador apresenta elementos que são passíveis de sofrerem recalque. Num plano individual, trata-se do marido de d. Benedita. Num plano coletivo, trata-se da escravidão no Segundo Reinado. Contudo, o marido e o escravo são figuras que "teimam" como a chuva e como não podia deixar de ocorrer em relação a elementos recalcados. A chuva "teimosa", aliás, não vai em direção oposta a D. Benedita, que se dispersa? Assim, a chuva incomoda a personagem, ao conotar um movimento oposto ao dela.

A mulher preta com o balaio na cabeça de quem o vento leva o pano pode ser uma figuração da condição da própria d. Benedita. Afinal, por que D. Benedita dirige sua percepção para um pano que voou e para a preta com balaio na cabeça? D. Benedita está numa função feminina e carrega um fardo como o cesto. $O$ cesto pode conotar o desejo da protagonista, entendido conceitualmente enquanto um "vazio" 41 . No caso de d. Benedita, o cesto, o vazio, encontra-se ao vento.

Numa leitura de planos latentes do conto, a observação do tempo e da preta não se gasta em mera descrição da paisagem, mas constitui uma cena externa que contribui para a caracterização do mundo interior da personagem. Inclusive, a paisagem aparece como observação da personagem. A distração de d. Benedita para o que se supõe banal - a vista da janela - demonstra, como se fosse uma "livre associação", o recorte da realidade que a personagem empreende, orientada por uma condição problemática em relação ao desejo.

Ao céu negro e à mulher negra, d. Benedita, de um ponto de vista branco e estereotipado, associa o dever de escrever uma, duas, todas as cartas ao marido ausente. Ironicamente, o marido é um "desembargador", juiz encarregado de liberar

\footnotetext{
${ }^{41}$ Luiz Alfredo Garcia-Roza alude ao conceito de desejo na psicanálise como um "vazio". O conceito remonta ao próprio Freud, em $A$ Interpretação dos sonhos, especialmente quando o psicanalista defende que o sonho é a realização de um desejo reprimido. Nesse sentido, a realização do desejo é necessariamente "simbólica" (GARCIA-ROZA, 2008, p. 186). Garcia-Roza retoma, ademais, Lacan, Kojève e Hegel, para explicar o desejo conceitualmente como um "vazio", segundo a interpretação lacaniana. Garcia-Roza explicita o percurso do psicanalista francês e suas fontes em relação ao desejo: "No caso do desejo humano ocorre algo completamente diferente. Ele é desejo de desejo, e não desejo de objeto. Ou se preferirmos: o objeto do desejo humano é outro desejo. Mesmo que se expresse sob a forma de desejo de objeto, esse objeto só é desejado porque objeto de desejo de outro sujeito. O que o homem deseja, sempre, é o desejo do outro. Neste caso, o que vai "preencher" o vazio do desejo não é um objeto, mas um outro vazio. Portanto, não há, como no desejo animal, falta de objeto, mas sim um vazio essencial e insuperável" (GARCIA-ROZA, 2008, p. 192).
} 
os entraves de processos em causa. No entanto, ele dificulta o trabalho de $d$. Benedita quanto ao desejo, o que vem a ser, para a personagem, "uma das coisas mais árduas do mundo".

Nota-se na passagem descritiva uma junção de elementos recalcados com 0 dever das cartas. A figuração do dever da escrita da carta, aliás, multiplica-se numa frase, de ritmo gradual e de estilo hiperbólico: "Magnífico dia para não sair, e, portanto, escrever uma carta, duas cartas, todas as cartas de uma esposa ao marido ausente" (ASSIS, 2008, p. 290). Dessa forma, podemos interpretar o ritmo de multiplicação das cartas como proveniente do acúmulo de demandas não simbolizadas que reaparecem, contudo, como "chuvinha teimosa".

D. Benedita, portanto, estava errada no pensamento de que ninguém viria tentá-la e não apenas porque dona Maria dos Anjos a visitaria, mas também em função do deslocamento da personagem em relação às demandas de seu desejo. Creio que o parágrafo condensa questões em torno da composição de d. Benedita. Não por acaso, trata-se do primeiro parágrafo do segundo capítulo. A interpretação que desenvolvo sobre a carta ao marido, o escravo, a chuvinha teimosa e a preta, aliás, é tributária da interpretação de José Miguel Wisnik (2008) do conto "Um homem célebre" no ensaio "Machado maxixe: o caso Pestana".

Numa passagem de seu artigo, Wisnik reconhece os comentários sobre a paisagem que ameaça chuva e sobre o desvelo do escravo com Pestana como significantes que desencadeiam a liberação de elementos recalcados. Entre os elementos recalcados, encontra-se a potência criadora na composição de uma polca, gênero popular igualmente reprimido:

Mas aí é que se realiza, também, a extraordinária viragem, cujo desencadear-se está cifrado na passagem referida. A narrativa figura uma conjunção de elementos triviais que guardam, no entanto, o poder de precipitar forças latentes e acumuladas numa direção-surpresa. A conversa vazia sobre o tempo junta difusamente o preto e a nuvem carregada, e dispara uma corrente associativa que desemboca em polca repentina: um retorno do recalcado, que converte momentaneamente o círculo vicioso em círculo virtuoso, deslocando o lugar falseado do padre-pai (WISNIK, 2008, p. 138-137).

Reconheço que as cenas, nos dois contos, conotam significações diferentes. Contudo, as duas guardam em comum o emprego aparentemente distraído da paisagem, que atua como uma sombra na composição subjetiva dos personagens. 
Ademais, as duas cenas fazem referência à imagem da chuva, à escravidão moderna e, em última instância, ao recalque.

Pestana luta contra uma herança simbólica que se lhe impõe. Ele cria as polcas facilmente, mas as rejeita, preferindo outro padrão musical, que é social e simbolicamente valorizado. Como demonstra Wisnik, o gesto está relacionado a problemas de constituição subjetiva e de filiação do personagem, mas também a questões sociais brasileiras (WISNIK, 2008).

No caso de d. Benedita, a senhora evita a indefinição que se passa em seu casamento. Assim, a tarefa de escrever uma carta ao marido ausente é mandatória, mas não se deseja realizar. De certa forma, as duas cenas - a de Pestana e a de d. Benedita - são opostas. A composição de polcas de Pestana vem-Ihe com facilidade, mesmo que ele a rejeite. A escrita da carta de $d$. Benedita, diferentemente, é feita com incontáveis desvios e percalços, mesmo que a personagem encene que deseja muito escrever uma longa carta ao marido.

Os elementos de recalque são figurados como detalhes em ambos os contos. No caso de Pestana, os detalhes constituem uma cadeia de significantes que permitem o retorno do recalcado. No caso de $d$. Benedita, ela se deixa falar por detalhes que o narrador atribui à sua percepção distraída, como em livre associação. Os detalhes não despertam o retorno do recalcado na personagem, mas auxiliam num acesso oblíquo de seu mundo interno.

Vejamos, portanto, como o plano de uma longa carta ao marido consome muito tempo não para ser realizado, mas sim para ser evitado. Após diversas interrupções, no fim do capítulo, d. Benedita escreve tudo, de forma resumida e apressada. A narração do conto passa às roupas, aos acessórios e às feições da personagem. Nesse excerto, creio que o diálogo em chave irônica com os temas da moda (vestuário e acessórios) em $A$ Estação é perceptível:

Enquanto ela compõe os babadinhos e rendas do roupão branco, um roupão de cambraia que o desembargador Ihe dera em 1862, no mesmo dia aniversário, 19 de setembro, convido a leitora a observar-Ihe as feições. Vê que não the dou Vênus; também não Ihe dou Medusa. Ao contrário de Medusa, nota-se-Ihe o alisado simples do cabelo, preso sobre a nuca. Os olhos são vulgares, mas têm uma expressão bonachã. A boca é daquelas que, ainda não sorrindo, são risonhas, e tem esta outra particularidade, que é uma boca sem remorsos nem saudades: podia dizer sem desejos, mas eu só digo o que quero, e só quero falar das saudades e dos remorsos. Toda 
essa cabeça, que não entusiasma, nem repele, assenta sobre um corpo antes alto do que baixo, e não magro nem gordo, mas fornido na proporção da estatura. Para que falar-lhe das mãos? Há de admirá-las logo, ao travar da pena e do papel, com os dedos afilados e vadios, dois deles ornados de cinco ou seis anéis.

Creio que é bastante ver o modo por que ela compõe as rendas e os babadinhos do roupão para compreender que é uma senhora pichosa, amiga do arranjo das coisas e de si mesma. Noto que rasgou agora o babadinho do punho esquerdo, mas é porque, sendo também impaciente, não podia mais "com a vida deste diabo". Essa foi a sua expressão, acompanhada logo de um "Deus me perdoe!" que inteiramente lhe extraiu o veneno. Não digo que ela bateu com o pé, mas adivinha-se, por ser um gesto natural de algumas senhoras irritadas. Em todo caso, a cólera durou pouco mais de meio minuto. D. Benedita foi à caixinha de costura para dar um ponto no rasgão, e contentou-se com um alfinete. $O$ alfinete caiu no chão, ela abaixou-se a apanhá-lo. Tinha outros, é verdade, muitos outros, mas não achava prudente deixar alfinetes no chão. Abaixando-se, aconteceu-Ihe ver a ponta da chinela, na qual pareceu-lhe descobrir um sinal branco; sentou-se na cadeira que tinha perto, tirou a chinela, e viu o que era: era um roidinho de barata. Outra raiva de d. Benedita, porque a chinela era muito galante, e fora-lhe dada por uma amiga do ano passado. Um anjo, um verdadeiro anjo! D. Benedita fitou os olhos irritados no sinal branco; felizmente a expressão bonachã deles não era tão bonachã que se deixasse eliminar de todo por outras expressões menos passivas, e retomou o seu lugar. D. Benedita entrou a virar e revirar a chinela, e a passá-la de uma para outra mão, a princípio com amor, logo depois maquinalmente, até que as mãos pararam de todo, a chinela caiu no regaço, e D. Benedita ficou a olhar para o ar, parada, fixa.

Nisto o relógio da sala de jantar começou a bater horas.

D. Benedita logo às primeiras duas estremeceu:

- Jesus! Dez horas!

E, rápida, calçou a chinela, concertou depressa o punho do roupão, e dirigiu-se à escrivaninha, para começar a carta. Escreveu, com efeito, a data, e um: - "Meu ingrato marido"; enfim, mal traçara estas linhas: - "Você lembrou-se ontem de mim? Eu...", quando Eulália lhe bateu à porta, bradando:

- Mamãe, mamãe, são horas de almoçar (ASSIS, 2008, p. 290-291).

A aparência de $d$. Benedita novamente é descrita por termos opostos e em má conciliação: "Toda essa cabeça, que não entusiasma, nem repele, assenta sobre um corpo antes alto do que baixo, e não magro nem gordo, mas fornido na 
proporção da estatura" (ASSIS, 2008, p. 290). Mais uma vez, podemos questionar como seria um corpo, não magro nem gordo, fornido na proporção da estatura que, por sua vez, é antes alta do que baixa. A ambiguidade na descrição do perfil físico é alta.

Os dedos "afilados" podem significar tanto dedos finos, quanto dedos que se encontram dentro de um padrão vigente de beleza. Por sua vez, seriam seus dedos vadios porque não se fixam em nada? Seriam vadios porque não trabalham, já que a casa tem escravos? Os anéis que oscilam em número de cinco ou seis remeteriam também à aliança? Nesse sentido, "vadio" como característica empregada para os dedos poderia conotar também o casamento "vadio", no sentido de "errático".

Quanto ao rosto de d. Benedita, há um piparote do narrador no leitor, quando se descreve a boca da senhora e seus desejos (o que comentarei adiante). No geral, o que se percebe é a flutuação no desenho de d. Benedita. Assim, os olhos são vulgares, mas de expressão bonachã. Sua boca, mesmo não sorrindo, é risonha. D. Benedita gosta do arranjo das coisas, mas é impaciente. Ela blasfema ao diabo, mas logo em seguida pede perdão a Deus. Sua cólera não dura mais de um minuto.

A cena conduzida pelo narrador mostra, então, como d. Benedita passa, com grande facilidade, da janela e do plano da carta ao rasgo do punho esquerdo do roupão, dele a um alfinete, deste alfinete a muitos outros ali esquecidos, desses últimos a uma chinela roída, e desta ao "ar". Assim se passa uma hora.

A contagem das horas e dos minutos parece empregada para significar 0 fracionamento do tempo em atividades mínimas e em informações detalhadas do cotidiano, entre as quais, d. Benedita se perde. Assim, por exemplo, ela tinha um modo de fitar dona Maria do Anjos que era "inquieto, miúdo, repetido, instantâneo" e não "persistente e longo" (ASSIS, 2008, p. 288). No segundo capítulo, arma-se, portanto, um conflito entre escrever uma carta ao marido e as atividades em que d. Benedita se dispersa. Como afirmado acima, d. Benedita enfrenta embargos, quando se compromete a escrever ao marido.

A dispersão de d. Benedita descreve-se por meio de suas percepções. Contudo, ela atua também em seu desenho moral, de forma negativa e não conciliadora. Deslocando-se às percepções "inquietas", "miúdas", "repetidas" e "instantâneas" (como as percepções da moda), d. Benedita recua em relação à imaginação de seu mundo interno. Assim, as emoções da personagem e sua imaginação moral não lhe aparecem como sendo de seu domínio. 
O plano de d. Benedita de escrever uma carta longa "trunca-se", pois a senhora não consegue concentrar-se na atividade, como não podia deixar de ser. José Antonio Pasta Jr. comenta, por exemplo, sobre como "D. Benedita" é um conto que dramatiza a "formação supressiva" como elemento da obra machadiana (informação verbal) ${ }^{42}$. Assim, Pasta Jr. chamava a atenção para a mobília da casa dessa senhora (informação verbal) ${ }^{43}$, pois lemos no conto:

Deixemo-las almoçar à vontade; descansemos nessa outra sala, a de visitas, sem aliás, inventariar os móveis dela, como não o fizemos em nenhuma outra sala ou quarto. Não é que eles não prestem, ou sejam de mau gosto; ao contrário, são bons. Mas a impressão geral que se recebe é esquisita, como se ao trastejar daquela casa houvesse presidido um plano truncado, ou uma sucessão de planos truncados (ASSIS, 2008, p. 291).

A sucessão de planos truncados na decoração remete-nos ao plano de escrita da carta. "Plano" ${ }^{44}$, ademais, é uma palavra ambígua que ganha tanto a conotação de "projeto", quanto de "esfera conceitual", "área imaginária", ou ainda de "representação pictórica" etc. Nota-se também o uso da palavra "trastejar" ${ }^{45}$, que não é de uso comum. "Trastejar" pode significar mobiliar, mexer com "trastes"

${ }^{42}$ Informação fornecida por José Antonio Pasta Jr. no curso "O Romance de Machado de Assis: metafísica e história" na Faculdade de Filosofia, Letras e Ciências Humanas da Universidade de São Paulo em 2011.

43 Idem.

${ }^{44}$ (pla.no)

$[\ldots]$

sm. [...] 5. Conjunto integrado de medidas projetadas para realizar alguma coisa ou alcançar um objetivo; PROGRAMA; PROJETO [+ contra, para: plano contra assaltantes: plano para a paz.

8. Grau de importância: $O$ combate à corrupção está em primeiro plano.: A viagem de férias ficou em segundo plano.

9. Fig. Projeto, intenção [+ para: plano para as férias.]

[...]

14. Fig. Situação, posição de destaque ou privilegiada: O protagonista tem de estar no primeiro plano. 15. Des. Cada uma das faixas paralelas imaginárias, perpendiculares ao ponto de onde se observa, em que se divide um corpo, uma cena etc., entre a superfície frontal e a de fundo: Esta imagem se divide em três planos.

16. Fot. Modo de enquadrar o tema de uma fotografia (plano do chão/superior) [...] (IDICIONÁRIO AULETE). Disponível em: http://aulete.uol.com.br/plano. Acesso em: 10/08/2013.

${ }^{45}$ (tras.te.jar)

v.

1. Comerciar com trastes, com coisas de pouco valor [int.]

2. Cuidar dos trastes domésticos [int.]

3. Cuidar dos afazeres de uma casa [int.]

4. Movimentar-se de um lado para outro [int.]

5. Comportar-se com esperteza, como um safado, um velhaco [int.]

6. Mobiliar (uma casa, um lugar) [td.]

7. Mús. Pôr trastos em; TRASTEAR [td.]

8. Mús. Bater com os dedos (nas cordas do violão) sobre os trastos [int.]

[F.: traste ou trasto + -ejar] (IDICIONÁRIO AULETE). Disponível em: http://aulete.uol.com.br/trastejar. Acesso em: 10/08/2013. 
domésticos. Creio que a palavra "traste", atualmente, guardou a conotação predominante de coisas de baixo valor. Porém, "trastejar" significa também "ir de um lado para o outro", "hesitar", "vacilar", "proceder fora das normas" - o que, mais uma vez, faz referência a um movimento dispersivo da personagem.

Lembremos que a descrição da mobília está em consonância com o diálogo entre o conto e $A$ Estação, que se voltava também para a decoração da casa. Assim, o diálogo intertextual preside observações do narrador para o leitor do seguinte tipo: "Deixemo-las almoçar à vontade; descansemos nessa outra sala, a de visitas, sem aliás inventariar os móveis dela, como não o fizemos em nenhuma outra sala ou quarto" (ASSIS, 2008, p. 291). Há ênfase nas duas mulheres (deixemo-las), excluindo-se o menino. Ademais, há interferências do narrador que revelam procedimentos de descrição e narração, evidenciando a construção ficcional do texto.

As dispersões do dia de d. Benedita incluem, ademais, uma visita de dona Maria dos Anjos. O triângulo formado por dona Maria dos Anjos, d. Benedita e Eulália figura uma luta entre as duas e a última. Contudo, há cumplicidade de compreensão entre Eulália e Maria dos Anjos versus o caráter dispersivo de d. Benedita. Na cena, diz-se que "D. Benedita é que não via nada" (ASSIS, 2008, p. 292).

O terceiro capítulo do conto começa com a prostração de d. Benedita por ter escrito uma carta longa. Contraditoriamente, no final do capítulo anterior, diz-se que ela havia resumido tudo. Lembremos a ideia de que d. Benedita leva quase o dia todo não para escrever a carta, mas sim para postergar a escrita. Da carta, a personagem passa imediatamente a um livro que a distraía. Aliás, conta-se que a senhora lia três livros ao mesmo tempo. Um deles mostrava um movimento de d. Benedita semelhante à amizade que matinha com d. Maria dos Anjos. Ela havia se atirado com furor na compra daquele livro "que chegara da Europa na véspera" (ASSIS, 2008, p. 294), tinha lido os primeiros capítulos, igualmente com furor, mas se esquecera dele no dia seguinte.

Dessa forma, quando Eulália fala do pai, d. Benedita distrai-se mais uma vez. Nessa cena, a senhora passa dos livros da moda a um colete. Assim, a veleidade, atua também no esquecimento, no sentido de recalque ${ }^{46}$. Enquanto $d$. Benedita

\footnotetext{
${ }^{46}$ Esquecimentos simples seriam alvos de Freud em Sobre a psicopatologia da vida cotidiana, ao lado de outros tipos de esquecimento, lapsos verbais, atos falhos, superstições, entre outros gestos
} 
distrai-se com as modas e a elas dirige sua percepção, a lembrança do casamento torna-se uma espécie de plano secundário:

- A carta foi?

- Foi; mandei o José a toda pressa. Aposto que mamãe esqueceu-se de dar lembranças a papai? Pois olhe, eu não me esqueço nunca.

D. Benedita bocejou. Já não pensava na carta; pensava no colete que encomendara à Charavel, um colete de barbatanas mais moles do que o último. Não gostava de barbatanas duras; tinha o corpo mui sensível, Eulália falou ainda algum tempo do pai, mas calou-se logo, e vendo no chão o livro aberto, o famoso romance, apanhou-o, fechou-o, pô-lo encima da mesa (ASSIS, 2008, p. 294).

Após Eulália dizer que não esquece "nunca", a mãe desvia da conversa com um bocejo e pensa num colete de uma modista famosa ${ }^{47}$. $O$ gesto da filha em guardar o romance também indica um fechamento por parte desta personagem em contraposição à mãe. Assim, no terceiro capítulo, evidencia-se, no conto, uma batalha entre as duas. Os perfis femininos da mãe e de Eulália são excludentes um do outro. Paradoxalmente, o narrador desentranha um retrato de personagem, a partir do outro. Dessa forma, enquanto compõe um retrato insustentável de d. Benedita, o narrador se vale de linhas firmes, ao desenhar Eulália.

$\mathrm{Na}$ composição de ambos os perfis percebe-se, por exemplo, a presença da análise moral das motivações das personagens. Nesse sentido, o conto dialoga com a tradição do retrato moral, como em La Rochefoucauld (1961) e La Bruyère (1937), por exemplo. Esse é um ponto em comum aos dois retratos. No entanto, os retratos das personagens são diferentes entre si. A relação de oposição dos perfis, inclusive, contribui para o desenho individual. Assim, D. Benedita torna-se ainda mais veleitária se contraposta a Eulália. Igualmente, o retrato de Eulália é ainda mais resoluto, quando comparado ao da mãe:

Eulália foi à janela, relanceou a vista pelo campo, e, se lhes disser que com uma pontazinha de tristeza nos olhos, podem crer que é a pura verdade.

banais de engano. Sobre o esquecimento de nomes, por exemplo, Freud conclui o seguinte: "O comum a todos esses casos, independentemente do material, é o fato de o esquecido ou distorcido estabelecer uma ligação por alguma via associativa, com um conteúdo de pensamento que foi fonte do efeito manifestado no esquecimento" (FREUD, 2006, p. 38). Assim, todos esses gestos aparentemente banais guardam relação com pensamentos recalcados.

${ }^{47}$ Na página MachadodeAssis.net, encontra-se nota a respeito da coleteira: "Segundo o Almanaque Laemmert de 1867, Mme. Henriette Charavel, "coleteira de sua majestade e Imperatriz e duas Altezas Imperiais" (isto é, as princesas, filhas de D. Pedro II e D. Teresa Cristina) tinha o seu ateliê na rua de São José, $76, \quad$ sobrado". Disponível em: http://www.machadodeassis.net/hiperTx romances/obras/papeisavulsos.htm. Acesso em: 10/07/13. 
Não era todavia a tristeza dos débeis ou dos indecisos; era a tristeza dos resolutos, a quem dói de antemão um ato pela mortificação que há de trazer a outros, e que, não obstante, juram a si mesmos praticá-lo, e praticam. Convenho que nem todas essas particularidades podiam estar nos olhos de Eulália, mas por isso mesmo é que as histórias são contadas por alguém, que se incube de preencher as lacunas e divulgar o escondido. Que era uma tristeza máscula, era; - e que daí a pouco os olhos sorriam de um sinal de esperança, também não é mentira.

- Isto acaba, murmurou ela, vindo para dentro (ASSIS, 2008, p. 291-292).

Novamente, comentários do narrador constituem intromissões no fluxo da narrativa. Os processos narrativos aparecem como parte da ficção: "[...] mas por isso mesmo é que as histórias são contadas por alguém, que se incube de preencher as lacunas e divulgar o escondido" (ASSIS, 2008, p. 291- 292). Outra vez, há alusões irônicas para que os leitores "creiam" que se trata da "pura verdade" (ASSIS, 2008, p. 291).

Notemos que enquanto o olhar de d. Benedita é "indeciso", a tristeza de Eulália, que é desenvolvida a partir do desdobramento do olhar, não é "a tristeza dos débeis ou dos indecisos", mas sim a "dos resolutos" (ASSIS, 2008, p. 291). A frase de Eulália que diz "Isto acaba", apesar de ser citada diversas vezes pela personagem, não é uma "ideia fixa". A frase da filha conota antes resolução. Assim, enquanto, a jovem repete "Isto acaba", o "trastejar" da casa d. Benedita é "presidido" por "uma sucessão de planos truncados" (ASSIS, 2008, p. 291). Em outras palavras, Eulália repete "Isto acaba" numa casa presidida por planos inacabados.

Portanto, pode-se interpretar que o "ofício do governo" da primeira frase do conto diz respeito também ao governo da casa. Nessa visada, a casa ganha uma dimensão ao mesmo tempo coletiva e individual. No primeiro sentido, ela está relacionada a um papel social. No segundo, a casa guarda relação com a figuração da pessoa moral de cada uma das personagens, d. Benedita e Eulália.

O ofício do governo de mulheres reduzia-se, então, ao governo da casa e do casamento. Tratando-se de uma narrativa sobre mulheres, que foi publicada originalmente num periódico para mulheres, a casa ganha conotações diversas às conotações que possuía numa sociedade patriarcal. Em "D. Benedita", inclusive, o ofício do governo da casa é investido de batalhas, com o uso de palavras e de imagens militares. 
Além de subjetiva, a casa torna-se política, no conto de Machado de Assis. Lembremos, aliás, que a casa de d. Benedita, encontrava-se no "Campo da Aclamação"48, bairro associado historicamente ao imperador. A última palavra, ademais, denota reconhecimento público. Lembremos, por exemplo, que os tipos modelares do periódico $A$ Estação instituíam representações, para as mulheres, numa sociedade patriarcal, não apenas de ordem subjetiva, mas também de ordem coletiva. Os papeis modelares da revista estavam relacionados ao consumo, ao desejo de ascensão social e à representação de como a mulher deveria comportarse em esferas sociais de proprietários.

Os embates domésticos mais substanciais giram, portanto, em torno do casamento. D. Benedita insta pelo casamento de Eulália com Leandrinho, mas desconfia de um "sujeito" "nas Laranjeiras" (ASSIS, 2008, p. 293). Quando a mãe fala a Eulália de Leandrinho e de dona Maria dos Anjos, ela, contudo, recua das reações da filha "como alguém que desanda uma rua para evitar um importuno" (ASSIS, 2008, p. 291).

$\mathrm{Na}$ apresentação mais demorada do retrato de Eulália, aliás, a personagem é conferida de autoconsciência, dizendo-se resoluta a cumprir gestos que trariam mortificação a outros. Ela e a mãe "bradavam". Creio que um detalhe vocabular desse tipo não vem ao acaso. Assim, Eulália e d. Benedita são descritas não apenas como opostas, mas também num embate de vida e morte. Cria-se uma batalha doméstica. Enquanto a moça reage friamente à visita de dona Maria dos Anjos, a mãe age de maneira expansiva. Na carta ao marido, d. Benedita trata principalmente da intenção de casar Eulália com o filho daquela senhora:

Mas você que pensa? Devo limitar-me a aconselhá-la, ou impor-lhe a nossa vontade? Eu acho que devo usar um pouco da minha autoridade; mas não quero fazer nada sem que você me diga. O melhor seria que você viesse cá (ASSIS, 2008, p. 293).

Os desdobramentos são conflituosos:

\footnotetext{
${ }^{48}$ Na página de MachadodeAssis.net encontra-se a seguinte nota: "O Campo da Aclamação, na primeira metade do século XIX, era um descampado, situado sobre terreno alagadiço, fora dos muros da cidade do Rio de Janeiro. Com a aclamação de D. Pedro como primeiro imperador do Brasil, ganhou a denominação de "Campo da Aclamação". Em 1873, sofreu ampla reforma urbanística, de autoria do paisagista francês Glaziou, tornando-se um lugar elegante e bem freqüentado. Como a República foi ali proclamada, ganhou o atual nome, Praça da República. O lugar também é conhecido como campo de Santana, devido à proximidade da igreja devotada a essa santa". Disponível em: http://www.machadodeassis.net/hiperTx romances/obras/papeisavulsos.htm. Acesso em: 03/06/2013.
} 
[Eulália] Era resoluta, tinha têmpera, podia resistir, e resistiu, declarando ao cônego, quando ele naquela noite the falou do Leandrinho, que absolutamente não queria casar (ASSIS, 2008, p. 294).

Quando referiu tudo a d. Benedita, esta ficou assombrada com os termos da recusa; mas tornou logo a si, e declarou ao padre que a filha não tinha vontade, faria o que ela quisesse, e ela queria o casamento (ASSIS, 2008, p. 295 [grifo meu]).

D. Benedita não respondeu nada; mas consigo, no mais fundo de si mesma, jurou que, houvesse o que houvesse, acontecesse o que acontecesse, a filha seria nora de d. Maria dos Anjos. E ainda consigo, depois de sair 0 cônego: - Tinha que ver! Um tico de gente com fumaças de governar a casa!

[...] Eulália - o tico de gente - levantou-se fresca, lépida, loquaz, com todas as janelas da alma abertas ao sopro azul da manhã. [...]

[...] D. Benedita afagara muito a ideia de a ver abatida, carrancuda, e gastara uma certa soma de imaginação em compor os seu modos, delinear os seus atos, ostentar energia e força. E nada! Em vez de uma filha rebelde, uma criatura gárrula e submissa. Era começar mal o dia; era sair aparelhada para destruir uma fortaleza, e dar com uma cidade aberta, pacífica, hospedeira, que lhe pedia o favor de entrar e partir o pão da alegria e da concórdia. Era começar o dia muito mal (ASSIS, 2008, p. 295-296 [grifo meu]).

E saiu, exasperada, com uma grande vontade de esganar a filha, dizendo consigo que a pior coisa do mundo era ter filhas. [...] (ASSIS, 2008, p. 296).

A ideia de "governar a casa" é expressa literalmente nesse momento do conto. D. Benedita tem expectativas de exercer autoridade sobre a filha. No penúltimo excerto citado, há uma metáfora bélica sobre a destruição de uma fortaleza. Eulália, contudo, é uma personagem que age taticamente, dentro do quadro de guerra privada. Considerando-se a metáfora política para a dona de casa e a metáfora bélica para o embate entre as duas, Eulália curiosamente é a personagem que tinha "uma reflexão profundamente maquiavélica" (ASSIS, 2008, p. 298).

No conto, os planos de Eulália surtem efeito e acabam justamente como a personagem deseja. Assim, d. Benedita nutre expectativas em ver a filha abatida, mas tem que lidar com sua boa disposição. Após a frustração, d. Benedita, aliás, tem um "ameaço de enxaqueca" (ASSIS, 2008, p. 296). A senhora deveria visitar dona Maria dos Anjos para instar pelo casamento de Eulália. Contudo, ao ser contrariada pela filha, ela se constrange por uma enxaqueca. Ou melhor, d. Benedita 
teve "um ameaço, ou uma suspeita de possibilidade de ameaço" (ASSIS, 2008 p. 296) de enxaqueca, o que faz com que esse achaque seja um dos mais imponderáveis da literatura brasileira.

Segundo a abertura do conto, a coisa mais árdua do mundo é o ofício do governo. Posteriormente, a frase aparece deslocada para que d. Benedita diga consigo que a "pior coisa do mundo era ter filhas" (ASSIS, 2008, p. 298). O governo, portanto, está ligado com um governo de senhoras.

O jantar com d. Maria dos Anjos corre desastradamente para d. Benedita, ajustando-se aos intuitos oblíquos de Eulália. D. Benedita chega ao ponto oposto de não querer mais fazer a visita. D. Benedita e d. Maria dos Anjos discutem um "projeto de passeio" (ASSIS, 2008, p. 296), mas Eulália adverte-a da enxaqueca mais uma cena do embate familiar. A filha mostra-se solícita, mas apenas com o fim de frustrar os planos que os outros personagens - sua mãe, a mãe de Leandrinho e o cônego - traçam para ela.

No retorno do passeio, no terceiro capítulo, revela-se o pretendente escolhido por Eulália. Era o sujeito das Laranjeiras. Os planos de Eulália eram, de fato, maquiavélicos, no sentido de táticos, discretos, com meios inquestionáveis, quando se visava chegar aos fins. Também por esse motivo, a repetição da frase "Isto acaba" cai bem às intenções da personagem. Eulália filia-se à rede de personagens femininas voluntariosas na obra de Machado de Assis: uma família composta por Guiomar, laiá Garcia e Capitu, por exemplo. Não por acaso, ainda dentro do circuito das metáforas de conotação política e bélica, o pretendido noivo de Eulália era um oficial da marinha.

Creio que no final do terceiro capítulo do conto, há mais uma comparação entre mãe e filha. Nesse trecho, o conto mostra o devaneio de ambas em relação ao casamento. Há uma espécie de plano duplo na narrativa. As cenas espelham-se, pois cada personagem revolve ideias sobre seu cônjuge. Cada uma reflete em seu quarto e à sua maneira. As maneiras são opostas, como se sabe. Eulália tem uma figuração nítida do noivo, ou seja, um retrato bem delineado. Já D. Benedita perdese num movimento inquieto em relação à lembrança do marido:

- Isto acaba.

E, satisfeita de si, antes de dormir, puxou uma certa gaveta, tirou uma caixinha, abriu-a, aventou um cartão de alguns centímetros de altura - um retrato. Não era retrato de mulher, não só por ter bigodes, como por estar 
fardado; era, quando muito, um oficial de marinha. Se bonito ou feio, é matéria de opinião. Eulália achava-o bonito; a prova é que o beijou, não digo uma vez, mas três. Depois mirou-o, com saudade, tornou a fechá-lo e guardá-lo.

Que fazias tu, mãe cautelosa e ríspida, que não vinhas arrancar às mãos e à boca da filha um veneno tão sutil e mortal? D. Benedita, à janela, olhava a noite, entre as estrelas e os lampiões de gás, com a imaginação vagabunda, inquieta, roída de saudades e desejos. O dia tinha-lhe saído mal, desde manhã. D. Benedita confessava, naquela doce intimidade da alma consigo mesma, que o jantar de D. Maria dos Anjos não prestara para nada, e que a própria amiga não estava provavelmente nos seus dias de costume. Tinha saudades, não sabia bem de que, e desejos, que ignorava. De quando em quando, bocejava ao modo preguiçoso e arrastado dos que caem de sono; mas se alguma coisa tinha era fastio, - fastio, impaciência, curiosidade. D. Benedita cogitou seriamente em ir ter com o marido; e tão depressa a idéia do marido the penetrou no cérebro, como se the apertou o coração de saudades e remorsos, e o sangue pulou-lhe num tal ímpeto de ir ver o desembargador que, se o paquete do norte estivesse na esquina da rua e as malas prontas, ela embarcaria logo e logo. Não importa; o paquete devia estar prestes a sair, oito ou dez dias; era o tempo de arranjar as malas. Iria por três meses somente, não era preciso levar muita coisa. Ei-la que se consola da grande cidade fluminense, da similitude dos dias, da escassez das coisas, da persistência das caras, da mesma fixidez das modas, que era um dos seus árduos problemas: - por que é que as modas hão de durar mais de quinze dias?

- Vou, não há que ver, vou ao Pará, disse ela a meia-voz (ASSIS, 2008, p. 297).

Eulália, depois de repetir o mote "Isto acaba", tem nas mãos um retrato. O detalhe é interessante porque o conto diz no subtítulo prestar-se justamente a "um retrato". No caso, o retrato do oficial da marinha é mantido em segredo, conforme as estratégias de Eulália. O narrador novamente interfere na narrativa, desvelando procedimentos de representação literária enquanto artifício, não pretendendo a um efeito "ilusório" de representação de uma suposta realidade empírica. Assim, após revelar os sentimentos de Eulália, o narrador questiona a personagem d. Benedita, de forma inquisitorial e dramática. Contudo, a última não dá vazão ao tom rigoroso da pergunta, pois se perdia "com a imaginação vagabunda, inquieta, roída de saudades e desejos" (ASSIS, 2008, p. 297). 
D. Benedita está na janela novamente, como quando observava a paisagem, a chuva e a preta. Dessa vez, contudo, é noite. A luz da ambiência noturna encontra-se num estado de difusão entre as estrelas e os lampiões. Assim como em "O espelho", trata-se de um momento de chiaroscuro subjetivo do conto (MEYER, 2008 , p. 53). Uma diferença que poderíamos apontar é que no conto de Jacobina, tratava-se da fusão ambígua da luz do luar e da luz de velas da sala. No caso de $d$. Benedita, existe antes uma difusão da luz pelas estrelas e pelos lampiões múltiplos, que é mais conforme à caracterização dispersiva da personagem. O chiaroscuro parece composto para desenvolver justamente a descrição da subjetividade da personagem, no sentido de vasculhar sua imaginação e seu mundo interior "naquela doce intimidade da alma consigo mesma" (ASSIS, 2008, p. 297) -, assim como o parágrafo precedente desvelara as motivações de Eulália.

Trata-se, portanto, de uma rara visada da questão do desejo na personagem. No segundo capítulo, em diálogo ríspido com o leitor, o narrador dizia, por exemplo:

A boca é daquelas que, ainda não sorrindo, são risonhas, e tem esta outra particularidade, que é uma boca sem remorsos nem saudades: podia dizer sem desejos, mas eu só digo o que quero, e só quero falar das saudades e dos remorsos (ASSIS, 2008, p. 290).

No entanto, no terceiro capítulo, o narrador retoma o assunto e afirma-o sem circunlóquios:

Tinha saudades, não sabia bem de que, e desejos, que ignorava.

[...] e tão depressa a idéia do marido Ihe penetrou no cérebro, como se the apertou o coração de saudades e remorsos, e o sangue pulou-lhe num tal ímpeto de ir ver o desembargador que, se o paquete do norte estivesse na esquina da rua e as malas prontas, ela embarcaria logo e logo (ASSIS, 2008, p. 297).

Assim, a composição do perfil físico de d. Benedita, no segundo capítulo, entremostrava conflitos internos da personagem por meio de afirmações reversas, rodeios e subentendidos. Naquele capítulo, a distração e a dispersão versus o capricho de exercer autoridade compunham um retrato moral instável. Dessa vez, contudo, o narrador explicita conteúdos antes desmentidos ou apenas circundados. Assim, a personagem tinha "saudades e desejos" (ASSIS, 2008, p. 297). Ademais, a lembrança do marido disparava-Ihe "saudades e remorsos" (ASSIS, 2008, p. 297). No entanto, o desvelamento do mundo interno de $d$. Benedita parece correr à sua revelia. Ela é trespassada por saudades e desejos, mas mesmo que eles invadam 
seus "estados mentais" ou "fluxo de consciência", a personagem não os "conhece bem" e os "ignora".

O remorso e a decisão de embarque de d. Benedita encontram-se ainda enquadrados numa dinâmica de inquietude e de veleidade. É à "meia-voz" que ela diz ir ao Pará, detalhe que conota antes indecisão do que intuito secreto. Há um vasculhar da imaginação moral de d. Benedita. No entanto, a imaginação dela não deixa de ser "vagabunda", "inquieta" e "roída". Sua imaginação encontra-se como a chinela galante que tinha um "roidinho de barata" e que irritara a senhora por menos de um minuto (ASSIS, 2008, p. 290) ${ }^{49}$.

Assim, no conto, são perceptíveis passagens cuja composição da personagem estrutura-se por meio de projeções. Ou seja, na cena em que d. Benedita olha a paisagem, sua percepção do mundo externo revela orientações de seu mundo interno. Da mesma forma, d. Benedita irrita-se com o roído da chinela por ter ela própria a imaginação "roída". Ou ainda, a personagem mostra-se fria com d. Maria dos Anjos, mas julga projetivamente que a amiga é que não tinha agido como de costume.

Dentro da mesma dinâmica veleitária, a decisão de ir ao Pará faz com que o fluxo de pensamento de $\mathrm{d}$. Benedita pule imediatamente para a resignação em deixar as modas da corte. As tendências da moda atuavam como elementos de distração para D. Benedita e como forma de não enfrentamento da situação conjugal. Assim, quando pensa em embarcar, as modas aparecem como algo a ser necessariamente abandonado. Evidencia-se um mecanismo de deslocamento.

Embora a corte pressuponha a agitação por oposição à província, ainda assim a personagem sente fastio. Dessa forma, d. Benedita pensa na "similitude dos dias", na "escassez das coisas", na "persistência das caras" e "na mesma fixidez das modas, que era um dos seus árduos problemas" (ASSIS, 2008, p. 297). O mote dos

\footnotetext{
${ }^{49}$ Pedro Meira Monteira observou o uso da palavra "roer" como relevante para a figuração da ideia fixa e das obsessões subjetivas em Machado de Assis. Entre outros exemplos, Monteiro cita a dedicatória de Memórias Póstumas de Brás Cubas: "Ao verme que primeiro roeu as frias carnes do meu cadáver dedico como saudosa lembrança estas memórias póstumas" (ASSIS, 2008, p. 625); e o episódio do pálio em Dom Casmurro: "Opas enfiadas, tochas distribuídas e acesas, padre e cibório prontos, o sacristão de hissope e campainha nas mãos, saiu o préstito à rua. Quando me vi com um das varas, passando pelos fiéis, que se ajoelhavam, fiquei comovido. Pádua roía a tocha amargamente. É uma metáfora, não acho outra forma mais viva de dizer a dor e a humilhação de meu vizinho" (ASSIS, 2008, p. 962). Informação verbal do Prof. Dr. Pedro Meira Monteiro na Faculdade de Filosofia, Letras e Ciências Humanas da Universidade de São Paulo, em novembro de 2013.
} 
árduos problemas reaparece. Antes ele fora usado na primeira fase do conto e estava implicado na caracterização da personagem. Fora empregado também quando d. Benedita se irritava com Eulália.

Nessa passagem, o mote das "coisas árduas" mostra o deslocamento da dificuldade de governar a casa e de governar o desejo para a dificuldade das modas. Ou melhor, mostra-se que o fastio e o tédio são o outro lado da moeda das mudanças vertiginosas. Complementarmente, podemos interpretar, a partir desse descolamento, que as demandas subjetivas de d. Benedita - "saudades", "desejos", "remorsos" - mostram-se num grau alto de não simbolização. Nesse sentido, o desenho moral de d. Benedita sugere que tantas são as demandas ignoradas pela personagem que nenhum tipo profuso de distração ou de moda bastaria.

Eulália, por sua vez, age discretamente, de forma simulada e dissimulada. Ela chega, por exemplo, a sugerir que a mãe comprasse logo os bilhetes da passagem ao Pará. D. Benedita hesita na compra. Não deixa nome para o paquete e age em falso. Na despedida de d. Maria dos Anjos, ela se comporta friamente, de maneira oposta à do início do conto. Nessa cena, d. Benedita tem "atitudes geladas", "olhar fixo no chão", "indiferença", "silêncio", dá "dois tristes beijos de pessoa morta" (ASSIS, 2008, p. 298).

Como se agisse por autoengano, d. Benedita adia a viagem por motivos de superstição. Ela não gostava de sexta-feira, dia de saída do paquete. Depois, a viagem é adiada por motivos "impenetráveis" 50 (ASSIS, 2008, p. 298). Na terceira vez, d. Benedita desiste em razão de um "incidente" (ASSIS, 2008, p. 298). O incidente diz respeito a novas relações de amizade.

A descrição das relações novas é feita na mesma medida de entusiasmo e com a mesma anotação de futilidades com que se descreve o início da amizade entre d. Benedita e d. Maria dos Anjos. Nós, leitores, sabemos, contudo, que não se trata de incidente. Trata-se dos planos de Eulália. Ainda assim é interessante observar que não se desenrola apenas um engano no conto, tramado pela filha para

\footnotetext{
${ }^{50}$ A ironia do narrador a respeito de racionalizações e de ações em falso dos personagens seria também posteriormente desenvolvida em "A cartomante" (1884), conto do livro Várias Histórias (1895). Assim, por exemplo, Camilo e Rita agem em falso e desviam-se sistematicamente de indícios que poderiam levá-los a conclusões mais palpáveis sobre terem sido descobertos em traição. Rita vai à cartomante e Camilo também. Sobre Camilo o narrador diz numa passagem tensa do conto: "... pensou rapidamente no inexplicável de tantas coisas" (ASSIS, 2008, p. 451). A adjetivação confere ironia à observação do narrador em relação ao personagem. Nesse sentido, é relevante ler a interpretação do conto em As armadilhas do saber, de Cleusa Rios P. Passos (2007).
} 
a mãe. Há também um gesto de autoengano na personagem d. Benedita. $O$ autoengano é articulado, quando os planos de d. Benedita truncam-se em função de suas próprias ações. Suas ações caminham em sentido contrário ao discurso que ela declara.

No primeiro capítulo, o parágrafo de abertura apresenta impasses na composição do retrato de d. Benedita. No segundo capítulo, o parágrafo de abertura capta as contradições internas à personagem, a partir de recortes banais de sua observação. No terceiro capítulo, trata-se das distrações de d. Benedita que são desviantes em relação ao assunto de seu casamento. No último capítulo, o narrador enumera formas sucessivas de como $d$. Benedita desviou-se dos planos da viagem ao Pará e não embarcou. Creio que à exceção do primeiro parágrafo do conto, que se ocupa em apresentar o retrato de impossível delineamento de d. Benedita, a abertura dos outros três capítulos aborda episódios de autoengano da personagem.

A personagem diz querer escrever uma carta longa ao marido, mas se desvia da atividade e se enfastia dela. Quando Eulália menciona o pai, d. Benedita pensa em coletes. Quando a mãe deve instar pelo casamento da filha, ela se encontra constrangida. Quando d. Benedita decide ir ao Pará, não vai. Ela própria racionaliza motivos sucessivos para a desistência. Há um descompasso entre o que d. Benedita declara querer e o que faz. Assim é que no início do conto o sujeito que falava a Leandrinho dizia de d. Benedita:

[...] Chorou uma noite inteira, no dia seguinte não quis almoçar, e deu todas as ordens para embarcar no primeiro vapor.

- Mas não foi?

- Não foi; desfez a viagem daí a três dias (ASSIS, 2008, p. 289).

Por um lado, d. Benedita incorre em autoengano. Por outro, há indicação irônica do narrador de que as novas relações se desenrolam conforme os planos de Eulália. Como já mencionado, o narrador ironiza o estilo de fala de d. Benedita. Assim é que se apresenta na narração o que já era tramado há tempos por Eulália como algo "obscuro" (ASSIS, 2008, p. 298). A obscuridade, no caso, poderia representar a percepção de d. Benedita. Ela sim era uma personagem que "não via nada" (ASSIS, 2008, p. 292):

Um dos pontos mais obscuros desta curiosa história é a pressa com que as relações se travaram, e os acontecimentos se sucederam. Por exemplo, uma das pessoas que estiveram em Andaraí, com D. Benedita, foi o oficial de marinha retratado no cartão particular de Eulália, primeiro-tenente 
Mascarenhas, que o conselheiro Beltrão proclamou futuro almirante. Vede, porém, a perfídia do oficial: vinha fardado; e D. Benedita, que amava os espetáculos novos, achou-o tão distinto, tão bonito, entre os outros moços à paisana, que o preferiu a todos, e lho disse. O oficial agradeceu comovido. Ela ofereceu-Ihe a casa; ele pediu-Ihe licença para fazer uma visita.

- Uma visita? Vá jantar conosco.

Mascarenhas fez uma cortesia de aquiescência.

- Olhe - disse D. Benedita - vá amanhã.

Mascarenhas foi, e foi mais cedo. D. Benedita falou-lhe da vida do mar; ele pediu-lhe a filha em casamento. D. Benedita ficou sem voz, pasmada. Lembrou-se, é verdade, que desconfiara dele, um dia, nas Laranjeiras; mas a suspeita acabara. Agora não os vira conversar nem olhar uma só vez. Em casamento! Mas seria mesmo em casamento? Não podia ser outra coisa; a atitude séria, respeitosa, implorativa do rapaz dizia bem que se tratava de um casamento. Que sonho! Convidar um amigo, e abrir a porta a um genro: era o cúmulo do inesperado. Mas o sonho era bonito; o oficial de marinha era um galhardo rapaz, forte, elegante, simpático, metia toda a gente no coração, e principalmente parecia adorá-la, a ela, D. Benedita. Que magnífico sonho! D. Benedita voltou do pasmo, e respondeu que sim, que Eulália era sua. Mascarenhas pegou-Ihe na mão e beijou-a filialmente.

- Mas o desembargador? disse ele.

- O desembargador concordará comigo (ASSIS, 2008, p. 298-299).

D. Benedita falara antes ao cônego que "a filha não tinha vontade" (ASSIS, 2008 , p. 295), mas a narrativa mostra um desenlace oposto quanto ao desejo de Eulália. É possível interpretar o comentário da mãe sobre "não ter vontade" novamente, a partir de uma perspectiva projetiva. Ou seja, o que d. Benedita diz sobre as coisas e sobre outrem auxilia na composição do próprio retrato moral da personagem. Como citado, percebemos o movimento projetivo de d. Benedita na observação que ela faz da paisagem, na reação que tem ao roído da barata e no comentário sobre a "frieza" de d. Maria dos Anjos. Todos esses são momentos do conto que possivelmente desvelam disposições emocionais da própria personagem. Os desvãos em d. Benedita desdobram-se a partir da oposição entre o que declara e a forma como age.

A surpresa e a estupefação de d. Benedita quanto ao pedido de casamento são descritas de forma irônica: "Que sonho! [...] era o cúmulo do inesperado" (ASSIS, 2008, p. 298). Sabe-se que o noivado era mais do que esperado por Eulália. Em adição, a farda do futuro genro como "espetáculo novo" (ASSIS, 2008, p. 298), 
além de dialogar com o espetáculo do status social de "O espelho", continua a endossar o emprego de metáforas militares para a alusão da casa e do casamento. Afinal, num conto que se volta à aparência das vestimentas, o uniforme figura uma roupa incomum que é investida do significado de um posto.

Ironicamente, d. Benedita se torna responsável pelo planejamento do casamento de Eulália. Quando a senhora tentara planejar a escolha do noivo da filha não teve sucesso. No entanto, o planejamento de uma cerimônia (que também pode ser entendida como um "espetáculo") condiz com o comportamento erradio da personagem. Segundo o narrador, nos preparativos da festa, "Ela ia de um lado para outro", continuando o movimento vertiginoso. O narrador cita, aliás, a forma como d. Benedita executava os preparos: "Não se detinha no mesmo objeto durante muito tempo" (ASSIS, 2008, p. 299). Cita, ademais, que Eulália, ajudava-a, ao "suprir as faltas", "corrigir os defeitos" e "cercear as demasias" (ASSIS, 2008, p. 299).

As cartas que Eulália troca com o noivo são descritas pelo narrador como "contínuas, longas e secretas, como no tempo do namoro" (ASSIS, 2009, p. 299). A comparação do narrador funciona como mais uma revelação de que os planos da moça datavam de tempo considerável. Ademais, as cartas de Eulália continuam a contrapor os desenhos da mãe e da filha, pois as cartas de d. Benedita ao marido, inversamente, conotam uma escrita errática, resumida e parcialmente pública. Ou seja, d. Benedita, apesar de nem sempre revelar o conteúdo das cartas ao desembargador, diz a todos sobre a escrita delas, a ponto de elas significarem um dever conjugal. As cartas da senhora ao marido tornam-se mais um indício incômodo que aponta para a simultaneidade dos estados de "casamento" e "não casamento".

D. Benedita se entusiasma excessivamente com o noivo da filha. Ela diz bem dele, inclusive ao marido, que dá resposta positiva ao casamento. Depois da cerimônia, contudo, o desembargador morre no Pará. Mais uma vez, há articulação irônica do narrador para se referir ao "acaso das coisas", pois Proença já anunciara estar doente. Tratava-se de um desfecho esperado. A notícia da morte do desembargador Proença é precedida pela seguinte reflexão no conto: "Mas a fortuna é caprichosa" (ASSIS, 2008, p. 30). A reflexão teria uma tônica moral, não fosse essa tônica abalada pela ironia. 
Os gestos contraditórios, a memória fugaz, a indecisão e a fantasia excessiva de d. Benedita são todos elementos que reaparecem condensados e encadeados nos episódios finais do conto como numa espécie de síntese (em má conciliação).

Como gesto contraditório, por exemplo, d. Benedita deseja ir ao Pará, ainda depois da morte do marido, para fazer um túmulo e "beijar a terra" do lugar (ASSIS, 2008. p. 300). A intenção é passível de ser interpretada como ato falho, pois a senhora nunca alcançara visitar o desembargador em vida. Visitá-lo em morte conotaria um gesto em falso. O leitor pode depreender, então, uma ponta de conspiração da parte do casal, Eulália e Mascarenhas, para dissuadir d. Benedita da ideia. Embora a intenção do casal seja sugerida pelo texto, ela não é declarada e a interpretação fica a cargo do leitor:

Depois da missa de sétimo dia, consultou a filha e o genro acerca da idéia de ir ao Pará erigir um túmulo ao marido, e beijar a terra em que ele repousava. Mascarenhas trocou um olhar com a mulher; depois disse à sogra que era melhor irem juntos, porque ele devia seguir para o norte daí a três meses em comissão do governo. D. Benedita recalcitrou um pouco, mas aceitou o prazo, dando desde logo todas as ordens necessárias à construção do túmulo. O túmulo fez-se; mas a comissão não veio e d. Benedita não pôde ir (ASSIS, 2008, p. 300).

A memória volúvel se mostra mais uma vez quando $d$. Benedita se esquece de convidar d. Maria dos Anjos para o casamento de Eulália ${ }^{51}$. Contudo, logo em seguida à lembrança da antiga amiga, d. Benedita se distrai novamente, pede açúcar ao escravo e pensa no carro que levaria o cônego (ASSIS, 2008, p. 300). Se, no inicio do conto, a amizade era efusiva, no último capítulo, ela se esvanece por esquecimento.

A teima como assunto reaparece no final. Em alguns trechos anteriores, a palavra ou a disposição teimosa já apareciam. No capítulo I, por exemplo, um "sujeito" diz sobre o desembargador Proença: "Aqui há tempos, disse-se que ele não teimava com a mulher, porque estava lá de amores com uma viúva" (ASSIS, 2008,

\footnotetext{
${ }^{51}$ Novamente surge o tema do "simples esquecimento". Creio que a cena dialoga com a noção de esquecimento de intenções. Freud abordou esse tipo de esquecimento em Sobre a psicopatologia da vida cotidiana: "De fato, às vezes não podemos furtar-nos à impressão de que tudo o que se pode dizer sobre o esquecimento e os atos falhos já é conhecido de todos como algo evidente. É mesmo de admirar que, ainda assim, seja necessário apresentar a sua consciência coisas tão conhecidas. Quantas vezes ouvi dizerem: 'Não me peça para fazer isto, tenha certeza de que vou esquecer!' A realização dessa profecia, portanto, decerto nada tem de místico: quem assim fala sente em si a intenção de não executar o pedido e apenas se recusa a confessá-lo a si mesmo. Além disso, o esquecimento das intenções é muito bem ilustrado pelo que se pode chamar de 'formação de falsas intenções' [...]" (FREUD, 2006, p. 165).
} 
p. 289). A chuvinha que d. Benedita observa, no segundo capítulo, é teimosa e está associada a elementos de recalque na narração. No terceiro capítulo, a palavra é usada numa das interferências irônicas do narrador, quando ele declara não insistir em explicações para o adiamento da viagem de $d$. Benedita: "Iriam no outro paquete. Não foram no outro; mas desta vez os motivos escapam inteiramente ao alcance do olhar humano, e o melhor alvitre em tais casos é não teimar com o impenetrável" (ASSIS, 2008, p. 298). No fim do conto, d. Benedita se irrita com o genro em razão de teimas (ASSIS, 2008, p. 300). A senhora havia começado e abandonado a construção de uma nova casa. Assim, o genro decidira acabar a obra:

[...] D. Benedita consentiu, e o ato era tanto mais honroso para ela, quanto que o genro começava a parecer-lhe insuportável com a sua excessiva disciplina, com as suas teimas, impertinências, etc. Verdadeiramente, não havia teimas; nesse particular, o genro de D. Benedita contava tanto com a sinceridade da sogra que nunca teimava; deixava que ela própria se desmentisse dias depois. Mas pode ser que isto mesmo a mortificasse (ASSIS, 2008, p. 300).

Nessa passagem do conto, poderíamos interpretar mais um olhar projetivo de d. Benedita? Assim, se o genro não era teimoso, seria com a própria teima que d. Benedita se irritava? Qual parcela no desenho de d. Benedita poderia ser de "teimas"? Seria absurdo considerar a "teima" como um lado complementar de d. Benedita? Seria a teima uma espécie de "sombra de sombra" de uma personagem volúvel?

Assim, por exemplo, noutros momentos do conto, d. Benedita diz "não" "peremptoriamente" (ASSIS, 2008, p. 297). "Peremptório" tem o significado de "definitivo" (IDICIONÁRIO AULETE). Ademais, logo depois que a filha e Mascarenhas dissuadiram d. Benedita da viagem ao Pará para fazer o túmulo do marido, ela "recalcitrou um pouco" (ASSIS, 2008, p. 300). Entre os significados de "recalcitrar" encontramos os seguintes: "insistir (em não obedecer, ou não ceder)"; "obstinar-se"; "resistir" (IDIONÁRIO AULETE).

D. Benedita também pensava na "similitude dos dias", na "persistência das caras", na "mesma fixidez das modas" (ASSIS, 2008, p. 297). Ela tinha, ao mesmo tempo, "fastio, impaciência e curiosidade" (ASSIS, 2008, p. 297). Em "D. Benedita", por um lado, há o movimento incessante de inquietação e de curiosidade, por outro, há o fastio. 
No comportamento da personagem d. Benedita, poderíamos desdobrar dois movimentos contraditórios e complementares. De um lado, há o movimento de deslocamento vertiginoso de seu interesse em relação a vários objetos. Esse movimento expressa a forma como d. Benedita enquanto personagem não assume desejos, apenas veleidades. De um lado complementar, a teima reside na relutância da personagem.

Ela pode ser interpretada como teimosa no sentido paradoxal de que não sai da condição da veleidade. Ademais, sua volubilidade não deixa de ser um movimento incessante. Lembremos que "incessante" quer dizer "ininterrupto". D. Benedita permanece numa espécie de "fixidez volúvel" ou de "volubilidade fixa"52. Nesse paradoxo, o quadro da imaginação moral da personagem não muda, embora ela esteja sempre em busca de novidades superficiais. A busca vertiginosa pela quimera, aliás, ajuda a personagem a se desviar do confronto com seu desejo. Trata-se de um círculo vicioso na composição de d. Benedita.

Ao mesmo tempo, as demandas do desejo que não são simbolizadas são teimosas. O marido não teima com d. Benedita, o que seria o mesmo que dizer que insistia em não insistir no casamento. D. Benedita planeja ir ao Pará diversas vezes, mas teima em não embarcar. Ela traça projetos, mas, paradoxalmente, sua teima consiste na interrupção deles.

Podemos afirmar que, em grande parte no conto, a questão do desejo da personagem contorna o tema do casamento, que conota tanto status social, quanto o erotismo. No fim do conto, a sensibilidade ao tema é visível:

Foi por esse tempo que um negociante, viúvo, teve idéia de cortejar D. Benedita. O primeiro ano da viuvez estava passado. D. Benedita acolheu a idéia com muita simpatia, embora sem alvoroço. Defendia-se consigo; alegava a idade e os estudos do filho, que em breve estaria a caminho de São Paulo, deixando-a só, sozinha no mundo. O casamento seria uma consolação, uma companhia. E consigo, na rua ou em casa, nas horas disponíveis, aprimorava o plano com todos os floreios da imaginação vivaz e súbita; era uma vida nova, pois desde muito, antes mesmo da morte do marido, pode-se dizer que era viúva. O negociante gozava do melhor conceito: a escolha era excelente.

\footnotetext{
52 Sobre o tema em Machado de Assis, conferir PASTA JR., José Antonio. "Changement et idée fixe (L'autre dans le roman brésilien)". In: QUINT, Anne-Marie (direction). Au fil de la plume. Cahier N. ${ }^{\circ}$ 10. Paris: Presses Sorbonne Nouvelle, 2003.
} 
Não casou. O genro tornou do Sul, a filha deu à luz um menino robusto e lindo, que foi a paixão da avó durante os primeiros meses. Depois, o genro, a filha e o neto foram para o Norte. D. Benedita achou-se só e triste; o filho não bastava aos seus afetos. A idéia de viajar tornou a rutilar-lhe na mente, mas como um fósforo, que se apaga logo. Viajar sozinha era cansar e aborrecer-se ao mesmo tempo; achou melhor ficar. Uma companhia lírica, adventícia, sacudiu-lhe o torpor, e restituiu-a à sociedade. A sociedade incutiu-lhe outra vez a idéia do casamento, e apontou-lhe logo um pretendente, desta vez um advogado, também viúvo.

- Casarei? não casarei? (ASSIS, 2008, p. 300-301).

A afirmação explícita da personagem para si mesma dizendo que já era viúva antes de o marido morrer tem efeito de choque no leitor. Esperamos talvez a possibilidade de uma nova visada da personagem sobre si mesma. Contudo, a tomada de consciência por parte de d. Benedita, espécie de balanço moral sobre sua vida de casada, não acarreta na assunção de desejo. A afirmação de que já era simbolicamente viúva passa como um fósforo que rutila e se apaga, se quisermos aludir à imagem do conto.

No entanto, a questão do desejo da personagem amplia-se. Podemos afirmar que o problema da veleidade de d. Benedita não toca apenas no tema do casamento, mas toca também nos impasses da composição de seu retrato:

Uma noite, volvendo D. Benedita este problema, à janela da casa de Botafogo, para onde se mudara desde alguns meses, viu um singular espetáculo. Primeiramente uma claridade opaca, espécie de luz coada por um vidro fosco, vestia o espaço da enseada, fronteira à janela. Nesse quadro apareceu-Ihe uma figura vaga e transparente, trajada de névoas, toucada de reflexos, sem contornos definidos, porque morriam todos no ar. A figura veio até ao peitoril da janela de D. Benedita; e de um gesto sonolento, com uma voz de criança, disse-lhe estas palavras sem sentido:

- Casa... não casarás... se casas... casarás... não casarás... e casas... casando ...

D. Benedita ficou aterrada, sem poder, mexer-se; mas ainda teve a força de perguntar à figura quem era. A figura achou um princípio de riso, mas perdeu-o logo; depois respondeu que era a fada que presidira ao nascimento de D. Benedita: - Meu nome é Veleidade, concluiu; e, como um suspiro, dispersou-se na noite e no silêncio (ASSIS, 2008, p. 301).

$\mathrm{Na}$ cena final do conto entrevê-se a intersecção entre os seguintes planos da narrativa: a dinâmica do desejo que toma forma de veleidade em função da rapidez com que os objetos são substituídos; o desejo recalcado que contorna a questão do 
casamento; e a fantasia (a "Veleidade"), que sai da imaginação de d. Benedita, para fazer uma aparição na "realidade externa". A quimera que se apresenta na figura da fada tanto é uma imagem alegórica para a representação do retrato de $\mathrm{d}$. Benedita, quanto coloca em xeque o registro narrativo do conto.

No primeiro caso, há um impasse quanto à noção de retrato. Ou seja, o conto narra a tentativa de apreender uma figura pessoal que se mostra impossível de ser delineada, que é d. Benedita. Para isso, não apenas o narrador captura seus atributos, que mudam incessantemente, como também procura a contraposição entre retratos diversos. Assim, a figura de d. Benedita escapa porque não se fixa numa "linha mestra" ${ }^{53}$. No fim, a "linha mestra" mostra-se como "veleidade". A quimera e a imaginação viva de d. Benedita externam-se na figura de uma fada substancial e etérea. Ela é substancial porque ela é a própria "Veleidade" com letra maiúscula. No entanto, é etérea porque foge do registro realista de representação.

A fada é um retrato alegórico. Nesse sentido, ela está mais próxima do desenho de um caráter. Lembremos que em momentos decisivos da revelação da imaginação moral de d. Benedita e de Eulália, elas olhavam pela janela. Dessa forma, no conto, a janela conota tanto o olhar subjetivo das personagens, se considerarmos a casa como metáfora psíquica ${ }^{54}$, quanto significa uma moldura. $\mathrm{Ou}$ seja, é "num quadro" que d. Benedita vê a fada (ASSIS, 2008, p. 301). Um problema adicional na noção de retrato do conto é que, após as tentativas de desenho singular de d. Benedita, ele encontra projeção numa figura alegórica. Em outras palavras, o desenho de $\mathrm{d}$. Benedita pretende-se retrato, mas desemboca no caráter.

A cena lembra o episódio de Jacobina que se olha no espelho e não se vê. Ao invés de sua imagem, ele vê uma "difusão de linhas" (ASSIS, 2008, p. 327). De maneira semelhante, a personagem de $\mathrm{d}$. Benedita se defronta com uma imagem de si que é, no mínimo, inusitada. Tanto Jacobina quanto d. Benedita sentem medo. No caso da senhora, ela se sente ironicamente "aterrada" e "não pode se mexer"

\footnotetext{
${ }^{53}$ A expressão é de conto de Raduan Nassar, "O ventre seco", que também aborda o tema do retrato moral em chave irônica: "10. Sabe, Paula, ainda que sempre atenta à dobra mínima da minha língua, assim como ao movimento mais ínfimo do meu polegar, fazendo deste meu canto o ateliê do desenhista que ia no dia-a-dia emendando traço com traço, compondo, sem ser solicitada, o meu contorno, me mostrando no final o perfil de um moralista (que eu nunca soube se era agravo ou elogio), você deixou escapar a linha mestra que daria caráter ao teu rabisco. Estou falando de um risco tosco feito uma corda e que, embora invisível, é facilmente apreensível pelo lápis de alguns raros retratistas; estou falando da cicatriz sempre presente como estigma no rosto dos grandes indiferentes" (NASSAR, 1997, p. 65-66).

${ }^{54}$ A expressão "janelas da alma" é citada no conto (ASSIS, 2008, p. 295).
} 
(ASSIS, 2008, p. 301). Ou seja, o terror de d. Benedita é referido por uma palavra que conota concretude: "aterrar" (ASSIS, 2008, p. 301). Concretude essa que contrasta com o tom fantástico da cena.

Aliás, a palavra "aterrar", além de dizer respeito ao susto de d. Benedita, também significa "aterrissar", ou ainda num campo semântico náutico, a palavra quer dizer "chegar em terra" (IDICIONÁRIO AULETE). Lembremos, por exemplo, que $d$. Benedita queria beijar a terra em que estava enterrado o desembargador. Em suma, sobrava-lhe chão, quando ela estava distante do marido, mas também lhe faltava chão, no sentido de que a composição da personagem não se firmava. Ademais, se durante todo o conto, ela se dispersou e se distraiu, planejou e interrompeu, na cena final ela fica imóvel.

D. Benedita não olha no espelho, mas sim por uma janela. No entanto, é como se olhasse no espelho porque a visão que ela tem na janela de Botafogo é projetiva. Ela vê o espetáculo da fada que presidiu seu próprio nascimento. Assim como no momento de solidão em que Jacobina não se vê no espelho, a visão de D. Benedita é evanescente.

Poderíamos ter a ilusão de que em razão de a personagem ser circunscrita num traço de caráter - a veleidade - a narração teria conseguido possivelmente apreender o seu desenho. Longe desse desfecho, contudo, acontece o oposto. Há um logro múltiplo na narração que se encontra armado contra a noção de retrato, contra o leitor do conto, contra o registro realista e contra uma noção cartesiana de sujeito.

Assim, o retrato de d. Benedita melhor se encontra desenhado, quando projetado num caráter de veleidade. No entanto, o caráter que essa fada representa é caráter nenhum. A figura da fada aparece "sem contornos definidos, porque morriam todos no ar" (ASSIS, 2008, p. 301).

Ademais, é provocativa a insinuação de que o retrato da personagem é apreendido quando falha a representação realista da realidade externa. A fada irrompe como quimera que dá a ver as "linhas mestras" (no fundo, difusas) da personagem, mas se dispersa na noite e no silêncio.

Assim como d. Benedita, nós leitores, ficamos "aterrados", quando o conto sai do chão de representação realista, abrindo-se para uma irrupção da narrativa maravilhosa. Considerando-se os diálogos irônicos que o texto estabelece, o conto parece antes sugerir uma impossibilidade do retrato. 
"A veracidade absoluta era incompatível com o estado social adiantado". Memórias Póstumas de Brás Cubas, Machado de Assis 


\section{3. "Galeria Póstuma” (1883)}

"Galeria Póstuma" é um dos contos de Histórias sem data (1884), publicado pela primeira vez em 2 de agosto de 1883, na Gazeta de Notícias. Pode-se supor que esse veículo era um meio privilegiado para a publicação dos contos de Machado de Assis, já que o autor recolheu em suas coletâneas grande parte dos títulos que nele foram impressos. Luis Filipe Ribeiro, por exemplo, defende a tese de um alinhamento entre o ethos do jornal Gazeta de Notícias, que era diário, popular e liberal, e o interesse de Machado de Assis em nele publicar seus contos mais experimentais (RIBEIRO, 2008, p. 12).

A essa altura, já havia acontecido a passagem para a chamada "segunda fase" da obra de Machado de Assis, divisão não de todo consensual. No caso de Histórias sem data, a maturidade das obras curtas de 1884 passava longe de suspeitas. A recepção crítica contemporânea de Machado de Assis que havia respondido perplexa ou indiferente à inovação das Memórias Póstumas de Brás Cubas (1881) conservara a mesma postura na recepção do livro de contos de 1882 , Papéis avulsos. Em 1882, o descaso era, inclusive, maior em função do gênero, que era pouco acolhido no período, especialmente no Brasil.

No caso de Histórias sem data, o cenário não foi diferente. O diletantismo persistiu por meio de críticas com característica de comentários. Como observou Ubiratan Machado, havia "um imenso descompasso entre a fragilidade das críticas, palavrosas e divagantes, e a altíssima qualidade da obra" (MACHADO, 2003, p. 149). Assim, Ubiratan Machado assinala a presença de apenas quatro notas por ocasião da publicação do livro, entre agosto e setembro de 1884, nos seguintes periódicos: Alter, Revista Ilustrada; Gazeta de Notícias; A Estação; e Gazeta Literária (MACHADO, 2003, p. 149).

$\mathrm{Na}$ nota da própria Gazeta de Notícias, de dois de setembro, assinada por "V." (Valentim Magalhães), o conto "Galeria Póstuma" ganha algum destaque. Lemos em "Notas à margem" observações muito breves e "palavrosas" (MACHADO, 
2003, p. 149) sobre um Machado de Assis que era ainda visto como um excêntrico, de fino estilo, e com alcance internacional ${ }^{55}$ :

"Cantiga de esponsais”, "Galeria póstuma”, “A segunda vida”, “Uma
senhora"... Cuidado! Ou irão todos! São histórias deliciosas de uma fatura
melindrosa, um pouco superiores à compreensão do vulgo, mas, por isso
mesmo, primorosas, de excepcional e elevadíssimo valor.
- Um esquisito, dirá o leitor banal.
- Um mestre, retrucará o crítico consciencioso.
Têm sobretudo um merecimento incontestável esses livros, repitamo-lo. E é
que se pode dizer, ao lê-los, como dizia o Benjamin, da Galeria póstuma, ao
ler o manuscrito do tio Joaquim Fidélis:
- Estou lendo um coração, livro inédito (V. Apud MACHADO, 2003, p. 149-
150).

A nota compara, portanto, todo o livro de contos Machado de Assis a um livro ficcional contido em "Galeria Póstuma", o diário manuscrito de Joaquim Fidélis. A comparação de Valentim Magalhães é excessiva. Contudo, chama atenção que a associação tenha sido feita justamente por meio da metáfora do livro como "um coração" (V. Apud MACHADO, 2003, p. 150). Assim, vale examinar como essa metáfora opera no conto. Vale examinar também qual a possível compreensão da obra machadiana em que Magalhães se baseia para estabelecer a comparação.

Para além da curiosidade de o personagem escritor de "Galeria Póstuma" chamar-se Joaquim, assim como o Joaquim Maria, ele, em adição, é reconhecido como autor apenas depois de morto. Nesse ponto, Joaquim Fidélis lembra um pouco o Brás Cubas. Outro ponto que se soma às pontes que ligam Machado de Assis, o autor (no sentido de estilo), a Joaquim Fidélis, o personagem escritor, é que os dois versam o costume retórico do desenho de perfis - retratos e caracteres. Leiamos, portanto, os primeiros parágrafos do conto:

Não, não se descreve a consternação que produziu em todo o Engenho Velho, e particularmente no coração dos amigos, a morte de Joaquim Fidélis. Nada mais inesperado. Era robusto, tinha saúde de ferro, e ainda na véspera fora a um baile, onde todos o viam conversador e alegre. Chegou a dançar, a pedido de uma senhora sexagenária, viúva de um amigo dele, que the tomou do braço e lhe disse:

\footnotetext{
55 "Não se escrevem todos os dias, mesmo na Inglaterra, mesmo em França, livros como esse de que ora me ocupo, e como os outros que deixei citados (Memórias póstumas, Papéis avulsos)" (V. Apud MACHADO, 2003, p. 149).
} 
- Venha cá, venha cá, vamos mostrar a estes criançolas como é que os velhos são capazes de desbancar tudo.

Joaquim Fidélis protestou sorrindo; mas obedeceu e dançou. Eram duas horas quando saiu, embrulhando os seus sessenta anos numa capa grossa, - estávamos em junho de 1879 - metendo a calva na carapuça, acendendo um charuto, e entrando lepidamente no carro.

No carro é possível que cochilasse; mas, em casa, malgrado a hora e o grande peso das pálpebras, ainda foi à secretária, abriu uma gaveta, tirou um de muitos folhetos manuscritos - e escreveu durante três ou quatro minutos umas dez ou onze linhas. As últimas palavras eram estas: "Em suma, baile chinfrim; uma velha gaiteira obrigou-me a dançar uma quadrilha; à porta um crioulo pediu-me as festas. Chinfrim!" Guardou o folheto, despiu-se, meteu-se na cama, dormiu e morreu (ASSIS, 2008, p. 371).

Nos primeiros quatro parágrafos, apresenta-se uma contradição entre a descrição de Joaquim Fidélis como senhor socialmente bem-visto e a escrita do personagem de palavras desdenhosas.

"Não, não se descreve a consternação que produziu em todo o Engenho Velho, e particularmente no coração dos amigos, a morte de Joaquim Fidélis" (ASSIS, 2008, p. 371). A primeira frase imita o tom de lamento na voz narrativa em terceira pessoa. A repetição da palavra "não" introduz sutilmente um problema de representação relativo às emoções. Afinal, como descrever a consternação em relação a uma morte? Assim, logo no início, entra em cena o problema da descrição do "coração" dos personagens. A reação consternada dos vivos ajuda, ademais, na caracterização da boa imagem pública que Joaquim Fidélis tinha.

A caracterização do personagem Joaquim é desenvolvida, de forma direta, por traços morais, físicos e por gestos: "conversador"; "alegre"; "robusto"; "tinha saúde de ferro"; "a calva"; "embrulhando seus sessenta anos numa capa grossa"; "protestou sorrindo"; "acendendo um charuto"; e "entrando lepidamente no carro" (ASSIS, 2008, p. 371).

A figura metonímica de "embrulhar os sessenta anos numa capa grossa" tanto antecipa a morte de Joaquim Fidélis pela ideia de "embrulhar" (ASSIS, 2008, p. 371), que remete a amortalhamento, quanto sugere sua dissimulação, considerando-se o emprego metafórico da palavra "capa" como superfície encobridora das intenções do personagem. Da mesma forma, a expressão de Fidélis, ao "protestar sorrindo", abre 
margem tanto para uma leitura tolerante do personagem, quanto para uma interpretação que reconheça sua dissimulação.

Num momento seguinte, as palavras escritas no manuscrito complementam a caracterização do personagem. Assim, elas revelam a impostura de Joaquim Fidélis e sua face impiedosa, ao reduzir toda a noite a uma festa ruim e as pessoas a tipos sociais: "chinfrim"; "obrigou-me"; "velha gaiteira"; "um crioulo" (ASSIS, 2008, p. 371).

O bairro é outro elemento que contribui para a caracterização do morto. $O$ Engenho Velho era uma antiga freguesia do Rio de Janeiro onde atualmente é a Grande Tijuca. Fundada por jesuítas, São Francisco de Xavier do Engenho Velho, no século 18, constituía um refúgio relativamente longe do centro. Ademais, as palavras "engenho velho" sugerem a prática retórica.

O personagem morava no Engenho Velho, mas podemos perguntar se era igualmente num "engenho velho" que residia sua escrita, já que ele cultivava a antiga técnica do desenho de perfis morais. Notamos, aliás, que a velhice é um dos traços importantes na caracterização de Joaquim Fidélis. Afinal, no segundo parágrafo, não é uma "senhora sexagenária" ("uma velha gaiteira", nas palavras do falecido) que o convida a mostrar como "os velhos são capazes de desbancar tudo" (ASSIS, 2008, p. 371)? Assim, a obra manuscrita de Fidélis tudo desbanca no conto.

Portanto, a abertura de "Galeria Póstuma" conta a história da morte de Joaquim Fidélis, narrando inicialmente o baile e a forma como ele se recolheu e faleceu. Contudo, ela também introduz a prática da escrita do diário, que se mostra reversa à prática aparente (pública e privada) do personagem.

Nesse sentido, lembro-me das "Teses sobre o conto", de Ricardo Piglia, que defende, entre outros aspectos, a duplicidade estrutural desse gênero curto:

I

Num de seus cadernos de notas, Tchekhov registra esta anedota: "Um homem em Montecarlo vai ao cassino, ganha um milhão, volta para casa, suicida-se". A forma clássica do conto está condensada no núcleo desse relato futuro e não escrito.

Contra o previsível e o convencional (jogar-perder-suicidar-se), a intriga se oferece como um paradoxo. A anedota tende a desvincular a história do jogo e a história do suicídio. Essa cisão é a chave para definir o caráter duplo do conto.

Primeira tese: um conto sempre conta duas histórias. 
O conto clássico (Poe, Quiroga) narra em primeiro plano a história 1 (o relato do jogo) e constrói em segredo a história 2 (o relato do suicídio). A arte do contista consiste em saber cifrar a história 2 nos interstícios da história 1. Um relato visível esconde um relato secreto, narrado de um modo elíptico e fragmentário.

O efeito de surpresa se produz quando o final da história secreta aparece na superfície (PIGLIA, 2004, p. 89-90).

Em "Galeria Póstuma", de fato, duas histórias abrem-se em torno de duas faces de Joaquim Fidélis: uma aparente, nas relações interpessoais; outra secreta até o fim de sua vida, a do autor do diário manuscrito. Existe, portanto, uma cisão, desde 0 início, que se mostra por meio da contradição entre o comportamento aparentemente sociável de Joaquim Fidélis no baile e o desprezo que sua escrita expressa naquela noite.

Contudo, a "história secreta" de Joaquim Fidélis, embora assim o seja para os outros personagens, não o é, exatamente, para o leitor suposto do conto. A ambiguidade de Fidélis nos é revelada gradualmente, desde o início, desdobrandose na leitura de cada trecho do diário. Diário que é descoberto pela família, mas lido na íntegra apenas pelo sobrinho Benjamin.

Assim, a forma como se desenvolve a leitura e a recepção do manuscrito em "Galeria póstuma" constitui a história que pode ser considerada como "segundo relato no conto clássico", conforme as teses de Piglia. Ou seja, a leitura que Benjamin conduz dos perfis desenhados pelo tio engendra o caso inusitado, que surpreende a nós, leitores, quando de sua conclusão.

Trata-se da história de um leitor, no momento da leitura, que ocupa uma posição peculiar em relação ao texto. $O$ efeito que esse texto, diário manuscrito ficcional, repercute no leitor também ficcional, que é Benjamin, pretende chocar os leitores implícitos do conto. A "segunda história" de "Galeria Póstuma" arma-se, portanto, a partir da existência do manuscrito, mas se desdobra, sobretudo, por meio da recepção de Benjamin como leitor dele.

No prosseguimento do conto, portanto, dá-se continuidade à descrição de Joaquim Fidélis e, apenas depois, entra em cena o sobrinho Benjamin. Conhecemos, por meio do narrador em terceira pessoa, a trajetória de vida de Joaquim Fidélis. Ele continua sendo descrito pelos seguintes aspectos: era amado no bairro; serviçal; sociável com amigos; deputado até a dissolução da câmara pelo Marquês de Olinda, em 1863; era conservador, mas gostava de ser chamado 
"SAQUAREMA"; no tempo da enunciação da narrativa, era considerado cético; "era rico e letrado"; formado em direito em 1842; "não fazia nada"; "lia muito"; depois de viúvo, nutriu em vão esperanças em algumas damas; e educou um sobrinho órfão, filho de sua irmã, que tinha se formado em ciências jurídicas em 1877 (ASSIS, 2008, p. 371-372).

Com mais elementos da caracterização de Joaquim Fidélis, percebemos a composição de um personagem, para quem a conversação e a expressão verbal como um todo eram muito relevantes. Ressalta-se em Joaquim a postura flexível nas conversas, que varia conforme o contexto, a sociabilidade frequente em rodas de jogo de cartas, o gosto pela língua (a ponto de lhe aborrecer uma determinada expressão historicamente asséptica), o gosto pelo hábito da leitura e uma relação de tutoria com o sobrinho:

Tão amado que ele era, com os modos bonitos que tinha, sabendo conversar com toda a gente, instruído com os instruídos, ignorante com os ignorantes, rapaz com os rapazes, e até moça com as moças. E depois, muito serviçal, pronto a escrever cartas, a falar a amigos, a concertar brigas, a emprestar dinheiro. Em casa dele, reuniam-se à noite alguns íntimos da vizinhança, e às vezes de outros bairros; jogavam o voltarete ou o whist, falavam de política. [...] Era conservador, nome que a muito custo admitiu, por the parecer galicismo político. SAQUAREMA é o que gostava de ser chamado.

Joaquim Fidélis deu-Ihe [a Benjamin] educação e fê-lo estudar [...] (ASSIS, 2008, p. 371-372 [grifo meu]).

Em seguida, Benjamin entra em cena no conto. O personagem aparece contraposto à dissolução de outro que, para ele, encarnava uma autoridade de configuração múltipla - tio, tutor e pai -, ao mesmo tempo em que é confrontado pelo enigma da morte:

Benjamin ficou atordoado. Não podia acabar de crer na morte do tio. Correu ao quarto, achou o cadáver na cama, frio, olhos abertos, e um leve arregaço irônico ao canto esquerdo da boca. Chorou muito e muito. Não perdia um simples parente, mas um pai, um pai terno, dedicado, um coração único. Benjamin enxugou, enfim, as lágrimas; e, porque lhe fizesse mal ver os olhos abertos do morto, e principalmente o lábio arregaçado, consertou-Ihe ambas as coisas. A morte recebeu assim a expressão trágica; mas a originalidade da máscara perdeu-se (ASSIS, 2008, p. 372).

Em reação à morte, a expressão de Benjamin encontra via pelos olhos. Para ele, a percepção que se fixa do morto é principalmente visual. O choro é intenso. $O$ 
olhar de Benjamin é carregado também de amor. Nessa cena, o jovem tem aquele tipo de olhar, segundo o qual um personagem vê o outro como singular. Afinal, "coração único" é a expressão utilizada pelo narrador na caracterização de Joaquim Fidélis, quando esta é colorida pelo afeto do sobrinho para o tio.

Lembremos que Bosi defende, por exemplo, a partir da análise de Dom Casmurro, que o tipo vê os outros como tipos, mas na esfera de personagens que se constituem como indivíduos e pessoas, os olhares são necessariamente enviesados pela singularidade, já que comportam os desejos e afetos humanos: "O tipo tende sempre a classificar o outro como tipo; mas quem ama cria para o ser amado imagens novas, únicas, incomparáveis" (BOSI, 2007, p. 34) . $^{56}$.

No entanto, "coração único" é também uma expressão investida de ironia pelo narrador. Conhecemos de antemão a duplicidade de Joaquim Fidélis. Nesse caso, a ideia de um "coração único" não se sustenta, porque a caracterização do personagem não o enquadra numa conformação unívoca. A expressão aponta para uma qualidade justamente contrária às qualidades que sintetizam a figura de Joaquim Fidélis, que é flexível, ambígua e dissimulada, pois ele é um personagem de faces que não se correspondem. O mundo interior de Joaquim Fidélis - não no sentido essencialista, mas sim no sentido de sua imaginação e dos pensamentos que guarda para si - não condiz com a imagem vista pelos outros personagens.

Nessa senda de interpretação, o valor dos olhos como motivo literário invertese. Se, por um lado, os olhos de Benjamin servem de meio para a expressão de emoções ternas, por outro lado, a vista dos olhos abertos do cadáver faz-lhe mal. Sentimentos de filiação (ao lado de sentimentos de fraternidade) encontram-se geminados à sensação de mal-estar. Assim, os olhos abertos do falecido Joaquim Fidélis, desde o início da descrição da cena, compõem junto com o "leve arregaço irônico da boca" uma "máscara original" (ASSIS, 2008, p. 372).

\footnotetext{
${ }^{56}$ É interessante que Elaine Scarry, quando discute o belo como conceito correlato da justiça, destaca o "singular" como um de seus aspectos: "Odysseus's speech makes visible the structure of perception at the moment one stands in the presence of beauty. The beautiful thing seems - is incomparable, unprecedented; and that sense of being without precedent conveys a sense of the 'newness' or 'newbornness' of the entire world" (SCARRY, 1999, p. 22). "A fala de Odisseu deixa visível a estrutura da percepção no momento em que alguém se encontra na presença do belo. $A$ coisa bela parece ser - é - incomparável, sem precedentes; a sensação de não precedência transmite a sensação de novidade e de nascimento do mundo todo [tradução minha]". Assim, o olhar orientado pelo afeto pode ser interpretado como um olhar dirigido para o belo. Creio que a comparação seja pertinente nos olhares de Bentinho a Capitu, por exemplo.
} 
A máscara na fiç̧ão de Machado de Assis orientou uma sólida recepção crítica da obra. Refiro-me, principalmente, às diversas noções de mascarada machadiana apreendidas pelos ensaios de Augusto Meyer e ao binômio "máscara e fenda" que é explorado pelo ensaio de Alfredo Bosi.

Em "Galeria póstuma", a noção de máscara ajuda a compor o rosto de um morto. Não um morto qualquer, mas sim um morto que se descobre ter sido autor. De um lado, há a expressão facial trágica, arranjada pelo sobrinho aterrorizado, de certa forma recalcando o trauma da morte. De outro lado, há a expressão fixada no momento de morte do indivíduo, "máscara original", expressão única de uma experiência intransferível ${ }^{57}$.

O personagem Joaquim Fidélis, ademais, está relacionado a dois tipos de máscara. Um deles é a "máscara original", último semblante em vida e primeiro na morte, que caracteriza um escritor irônico e seu estilo. O outro tipo de máscara é aquele que, para Joaquim Fidélis, possuía forte significado em vida. Ou seja, o personagem era um dissimulado, conversava e agia de uma forma, mas guardava pensamentos de outra ordem. Assim, a máscara que o personagem usava, quando vivo, era uma de suas faces cotidianas. Trata-se de uma máscara que é um instrumento para a farsa representada no dia a dia, na posição de um senhor proprietário, que contribuía para o funcionamento do mecanismo de favor em relação a uma parentela que lhe circundava.

Augusto Meyer, por exemplo, aborda a máscara de duas formas distintas em diferentes momentos de sua crítica. Num deles, a máscara é uma representação social que presa às convenções faz com que o indivíduo circule entre os homens. Nesse caso, o crítico analisava "O espelho" em 1935:

Ora, Jacobina somos nós. Botamos a farda e representamos uma paródia do nosso eu autêntico - não na vida social apenas, na vida profunda do espírito, que anda quase sempre fardado. O imperativo do instinto vital se encarrega de fardar o espírito para que ele não se veja no espelho tal como

\footnotetext{
57 O problema da impossibilidade de transferência da dor e do gozo (no sentido lacaniano) é mencionado, por exemplo, em ensaio de Mário Eduardo Costa Pereira, que aborda a alteridade e a solidão do sujeito, a partir do referencial psicanalítico, no romance $A$ hora da estrela, de Clarice Lispector: "A alteridade constitui, assim, uma dimensão essencial da experiência psicanalítica. A recusa que esta se impõe de toda tentativa de "compreensão" do outro coloca-se como um pivô entre a técnica e ética da psicanálise: o que pode haver de mais abjeto do que afirmar ao desesperado: "eu compreendo a tua dor"? A dor, como o gozo, são experiências radicalmente íntimas, intransferíveis, marcas abomináveis de nossa absoluta solidão. A capacidade do analista de sustentar essa instância de alteridade irredutível é fundamental para que uma análise constitua, de fato, uma possibilidade de encontro com algo da própria verdade" (PEREIRA, 1998, p. 12-13).
} 
é na verdade. Só existem as almas exteriores, bovarizadas, mascaradas, e para elas, que só navegam na sabedoria da superfície, é melhor não sondar a profundidade terrível do homem. Quem tira a farda, quem tenta ver o que há além da fantasmagoria organizada em seu proveito pela inconsciência vital, sente a vertigem de si mesmo e de tudo, acaba falando sozinho diante do espelho, como o alferes Jacobina. Aliás, logo torna a vesti-la, num movimento reflexo de defesa (MEYER, 2008, p. 54).

Noutro momento, a máscara é um artifício liberador em relação aos recalques sociais e permite tudo dizer. Nessa visada crítica específica, em 1958, Meyer analisava a polêmica da viravolta machadiana, sobretudo, a partir das Memórias Póstumas de Brás Cubas:

É verdade que agora, afivelando ao rosto a máscara de Brás Cubas, vai despejar muita coisa que andava guardada e mais ou menos dissimulada. A psicologia da máscara - todos nós o sabemos muito bem por experiência, neste país do carnaval - é justamente a de um desafôgo compensador, que admite a irrupção de verdades recalcadas. Trocada a identidade, alteradas as condições de ser e parecer, o Eu autêntico se entrega à desforra sincera, e o que seria escândalo dentro da norma cotidiana, cai na conta da graça goliardesca.

Mas o mascarado, além de trocar de cara, também põe na voz a máscara do falsete: você me conhece? E um dos maiores divertimentos do carnaval sempre foi êsse desafio do falsete, a pular das frinchas da máscara, e acompanhado pelo brilho malicioso de uns olhos que o confirmam e desmentem ao mesmo tempo, nos seus falsos buracos de órbita... (MEYER, 1958, p. 13)

Num caso, a máscara reprime a instância que Meyer chama de "Eu autêntico", no outro, ela a libera. Em relação a "O espelho", o ato de mascarar-se representa uma forma de ser cooptado pelo status social e inserir-se em sociedade. Assim, Jacobina, depois do enfrentamento da vertigem, volta a se fardar para se alinhar a uma representação social estável. Já nas Memórias Póstumas, para Meyer, a máscara desenha uma face inanimada com buracos de órbita ocupados por olhos que confirmam e desmentem. Trata-se do recurso ao "autor suposto" ou ao "autor ficcional". Brás Cubas, o defunto autor, é uma máscara autoral que permite a "irrupção de verdades recalcadas" (MEYER, 1958, p. 13) no romance, instaurando um carnaval que dá livre vazão a inversões e transgressões.

No caso de "Galeria Póstuma", observamos o uso da máscara das duas formas. Num deles, a hipocrisia é inerente às relações sociais, ao bom andamento 
de uma vida de salão e ao estabelecimento de laços de favor. Assim, a máscara nas relações interpessoais é praticada por todos os personagens. Noutro uso, o personagem Joaquim Fidélis assume a identidade de um escritor de diário que desenvolve um estilo, segundo o qual, os perfis de seus conhecidos são traçados de forma extremamente franca. Esse estilo de escrita, supostamente confidencial, compõe outro tipo de máscara cujo uso admite "a irrupção de verdades" (MEYER, 1958, p. 13) que não apareceriam comumente em ocasiões de sociabilidade.

Vejamos, por exemplo, como no conto é retratada a forma como os homens mais próximos a Joaquim Fidélis reagem à notícia de sua morte numa espécie de velório íntimo. É interessante o uso da expressão "familiar de" (ASSIS, 2008, p. 372) para se referir aos personagens presentes. A expressão designa antes uma parentela constituída pelo favor do que uma relação de parentesco por laços de sangue ou matrimônio:

Diogo Vilares era um dos cinco principais familiares de Joaquim Fidélis. Devia-Ihe o emprego de 1857. Veio ele; vieram os outros quatro, logo depois, um a um, estupefatos, incrédulos. Primeiro, chegou o Elias Xavier, que alcançara por intermédio do finado, segundo se dizia, uma comenda; depois entrou o João Brás, deputado que foi, no regime das suplências, eleito com 0 influxo do Joaquim Fidélis. Vieram, enfim, o Fragoso e o Galdino, que não the deviam diplomas, comendas nem empregos, mas outros favores. Ao Galdino, adiantou ele alguns poucos capitais, e ao Fragoso arranjou-lhe um bom casamento... E morto! morto para todo sempre! De redor da cama, fitavam o rosto sereno e recordavam a última festa, a do outro domingo, tão íntima, tão expansiva! E, mais perto ainda, a noite da antevéspera, em que o voltarete do costume foi até as onze horas (ASSIS, 2008, p. 372).

Cada personagem é descrito pelo nome completo e pelo favor que devia a Joaquim Fidélis. De alguns dos personagens diz-se a profissão, mas apenas se ela está relacionada diretamente ao favor concedido. Na verdade, a lista de favores inclui, por metonímia, o parente por laço sanguíneo, Benjamim, pois era ele quem Ihe devia o diploma. Os cinco "familiares" de Joaquim Fidélis "fitavam o rosto sereno" (ASSIS, 2008, p. 372), ou seja, a expressão do rosto depois de recomposto pelo sobrinho.

Eles se lembravam do falecido, especialmente, nos momentos de sociabilidade. Portanto, há mais sinais de hipocrisia relacionados à convivência no "estado social adiantado" (ASSIS, 2008, p. 711). A narração dá a entender que a 
presença dos personagens justifica-se pelos favores que receberam. No entanto, o que ela comunica como recordação nos vivos são os momentos lúdicos que passaram com o falecido. Na ocasião em que veem o corpo, não poderia o Diogo Vilares lembrar-se do emprego que Joaquim Fidélis tinha Ihe concedido, não seria de bom tom. Então, o reconhecimento do legado "do familiar" desloca-se às atividades frívolas: a festa e o voltarete. Não se associa à recordação dos personagens o "diploma" ou as "comendas", mas sim os "excelentes charutos" e "os doces secos para os pequenos" (ASSIS, 2008, p. 372).

Eis que, na segunda parte do conto, passado o enterro e após a missa de sétimo dia, Benjamin encontra o diário de Joaquim Fidélis na presença dos amigos. Eles louvam o morto. Lêem trechos do diário e admiram a escrita. Contudo, quando está só, o sobrinho encontra no diário do tio os retratos dos cinco "principais familiares".

Os perfis desenhados por Joaquim Fidélis oferecem um contraponto do convívio segundo a dinâmica da máscara cotidiana. Oferecem um contraponto, ademais, da forma como "os cinco familiares" (ASSIS, 2008, p. 372) são descritos no velório, enterro etc. Assim, por oposição à amabilidade dos vivos que choram pelo morto, Joaquim Fidélis escrevia no seguinte estilo:

"Diogo Vilares - Tenho-me referido muitas vezes a este amigo, e fá-lo-ei algumas outras mais, se ele não me matar de tédio, coisa em que o reputo profissional. Pediu-me há anos que the arranjasse um emprego, arranjei-Iho. Não me avisou da moeda em que me pagaria. Que singular gratidão! Chegou ao excesso de compor um soneto e publicá-lo. Falava-me do obséquio a casa passo, dava-me grandes nomes; enfim, acabou. Mais tarde relacionamo-nos intimamente. Conheci-o então ainda melhor. C'est le genre ennuyeux. Não é mau parceiro de voltarete. Dizem-me que não deve nada a ninguém. Bom pai de família. Estúpido e crédulo [...]" (ASSIS, 2008, p. 374). "Elias Xavier - Este Elias é um espírito subalterno, destinado a servir alguém, e a servir com desvanecimento, como os cocheiros de casa elegante. Vulgarmente trata as minhas visitas com alguma arrogância e desdém: política de lacaio ambicioso. Desde as primeiras semanas, compreendi que ele queria fazer-se meu privado; e não menos compreendi que, no dia que o realmente fosse, punha os outros no meio da rua. Há ocasiões em que me chama a um vão da janela para falar-me secretamente do sol e da chuva. O fim claro é incutir nos outros a suspeita de que há entre nós coisas particulares, e alcança isso mesmo, porque todos thes rasgam muitas cortesias. É inteligente, risonho e fino. Conversa muito bem. 
Não conheço compreensão mais rápida. Não é poltrão nem maldizente. Só fala mal de alguém por interesse; faltando-lhe interesse, cala-se; e a maledicência legítima é gratuita [...]"(ASSIS, 2008, p. 374).

Trata-se de retratos. Aliás, a palavra "retrato" no conto aparece textualmente para designar as vinhetas de perfis no diário (ASSIS, 2008, p. 374). Contudo, percebemos na descrição dos amigos empreendida por Joaquim Fidélis a retomada do costume retórico de caracteres. Lembremos, ademais, que as duas maneiras do desenho verbal de perfis - o retrato e o caráter - não são necessariamente excludentes entre si.

Por um lado, os excertos podem ser considerados retratos porque se referem a aspectos singulares dos personagens como, por exemplo, nome completo e elementos da história pessoal. Por outro, há nos desenhos a ênfase no caráter porque eles recorrem a vícios morais e a traços negativos que são de ordem tipológica.

Nos desenhos de Fidélis, os seguintes elementos concorrem para a tônica do caráter $^{58}$ : a brevidade; a descrição de alguns elementos externos, como traços físicos; o detalhe condensado; as historietas particulares que se abrem, contudo, para a representação de características alegóricas, na maior parte, negativas; e a sensação de concretude que é decorrente da descrição.

Todos os personagens têm nome e sobrenome, além de uma construção de efeito realista. No entanto, eles são caracterizados por traços típicos. Vejamos o exemplo de Diogo Vilares. Joaquim Fidélis considera-o íntimo, reconhece que é bom no âmbito familiar, mas the desenha como um bajulador, um estúpido e como uma espécie de personificação do tédio.

Elias Xavier, por sua vez, é descrito como "inteligente" (ASSIS, 2008, p. 374). No entanto, essa palavra rapidamente desliza para outra de significado negativo: "astúcia" (ASSIS, 2008, p. 375). O personagem colocava em uso sua astúcia, quando movido invariavelmente por interesse pessoal. Logo, além de ser referido diretamente como subalterno, ele é personificado negativamente como interesseiro, traço que é a sua marca maior.

Joaquim Fidélis descreve gestos particulares de Xavier que são, contudo, submetidos à constante do interesse, além de coloridos pelo humor do estilo. Vejase, por exemplo, o seguinte gesto recorrente e cômico:

\footnotetext{
${ }^{58}$ Cf. seção 1.2 da Parte I.
} 
Há ocasiões em que me chama a um vão da janela para falar-me secretamente do sol e da chuva. O fim claro é incutir nos outros a suspeita de que há entre nós coisas particulares, e alcança isso mesmo, porque todos Ihes rasgam muitas cortesias (ASSIS, 2008, p. 374).

Assim, há uma mistura entre o tom da descrição de um indivíduo conhecido por Joaquim Fidélis, que é histórico e ancorado numa suposta realidade (embora este artifício seja criado ficcionalmente), e o tom caricatural que provém do desenho de tipos, que inclui características negativas e positivas, mas com realce das primeiras.

As características negativas são predominantes e causam impressão no leitor. Como mencionado anteriormente, grande parte da impressão advém do contraste entre as atitudes cordiais de Joaquim Fidélis no convívio com os outros personagens versus o estilo zombeteiro da escrita que mantinha secretamente. Lembremos, ademais, que a técnica da descrição por meio do caráter pretende ser impactante. O autor Joaquim Fidélis utiliza-se dela e, de fato, choca por meio de sua escrita, "desbancando tudo", principalmente a comezinha hipocrisia das relações sociais.

Pensemos, nesse sentido, no nome do personagem. "Joaquim" quer dizer "elevação". É um nome de origem bíblica, que pertence a dois reis de Judá, um deles o progenitor da Virgem Maria. "Fidélis", de origem espanhola, significa fiel. Evidentemente há ironia no emprego do nome do personagem escritor.

Podemos desdobrar as seguintes interpretações: Joaquim é elevado em sua posição social, mas essa é também rebaixada porque circunscrita ao bairro; numa lógica social de favor e escravocrata, ter status elevado significa também ser socialmente rebaixado. Lembremos que o costume retórico do caráter foi empregado historicamente para a composição de personagens da comédia, ou seja, para personagens de um gênero baixo, não elevado.

Em relação ao sobrenome, "Fidélis", pode-se desdobrar a interpretação de que o personagem é um retratista fiel:

[...] Era prova de uma rara isenção de espírito. De resto, o finado era exímio nos retratos. Desde 1873 ou 1874, os cadernos vinham cheios deles, uns de vivos, outros de mortos, alguns de homens públicos, Paula Sousa, Aureliano, Olinda, etc. Eram curtos e substanciais, às vezes três ou quatro rasgos firmes, com tal fidelidade e perfeição, que a figura parecia fotografada. Benjamin ia lendo; [...] (ASSIS, 2008, p. 374). 
Porém, ao retratar de forma negativa seus "cinco familiares" (ASSIS, 2008, p. 372), o personagem trai a confiança dessas figuras, reduzindo-as a tipos. Nada fiel às suas relações, portanto. Nesse sentido, Joaquim Fidélis também se compõe parcialmente como personagem tipológico. Pois, como elo forte na cadeia social de favores, ele exerce o capricho de retratar os outros conforme uma convenção dirigida originariamente a personagens baixos. Mesmo na prática escrita, ele não é um autor original porque opera num sistema de convenções retóricas e moralistas do desenho de perfis. Contudo, Joaquim Fidélis possui originalidade enquanto personagem, se considerada a sua composição cindida. Ademais, ele possui um dado de originalidade confluente ao Brás Cubas, no sentido da reatualização excêntrica, no século 19, da tradição satírica do morto como autor.

O narrador em terceira pessoa reforça a descrição dos tipos, no conto, porque os cinco personagens familiares são descritos em função do interesse ancorado no status social, que os prendia ao morto proeminente do bairro. Assim, quando a voz do narrador descreve os cinco, ela não sugere intimidade psicológica. Porém, a voz narrativa conserva ironicamente intacta a hipocrisia, endossando-a como prática corrente. Acima, observamos a hipocrisia, máscara cotidiana, conduzida pelos personagens, por exemplo, na cena do velório. A mesma forma de descrição aplicase ao enterro e à sequência que sucede a missa de sétimo dia, entre outras passagens do texto.

Já a escrita de Joaquim Fidélis, máscara autoral da escrita em segredo, valese igualmente da caracterização tipológica, mas desbanca a hipocrisia das relações sociais, que são simultaneamente de amizade e de interesse. Assim, a descrição dos cinco familiares composta pelo narrador do conto em terceira pessoa é irônica também porque se encontra contraposta à descrição realizada por Joaquim Fidélis.

A voz do narrador descreve tipos e conserva ironicamente os requisitos da hipocrisia. A voz do autor do manuscrito, Joaquim Fidélis, descreve tipos, mas se vale de uma franqueza sumária e retórica. Por trás dessas instâncias - a voz do narrador do conto e a voz da escrita do personagem morto -, há o autor implícito que arranja a contraposição entre uma e outra, visando ao efeito de ironia:

Com efeito, era um diário das impressões do finado, espécie de memórias secretas, confidência do homem a si mesmo. Grande foi a comoção dos amigos; lê-lo era ainda conversá-lo. Tão reto caráter! tão discreto espírito! 
Benjamin começou a leitura; mas a voz embargou-se-lhe depressa, e João Brás continuou-a (ASSIS, 2008, p. 373).

Lê-lo era inverso a conversá-lo. Na conversa em vida, a hipocrisia era alimentada. O narrador do conto expressa os sentimentos ou as falas dos personagens do convívio familiar por meio de discurso indireto livre. Assim, os comentários que ele tece destoam propositadamente dos efeitos que os manuscritos de Joaquim Fidélis causam. As memórias secretas, aliás, eram secretas não porque revelassem experiências íntimas de Joaquim Fidélis, como se espera de um diário. Elas eram, de fato, "confidência do homem a si mesmo" (ASSIS, 2008, p. 373), mas antes sobre terceiros. Assim como o Memorial de Aires, o diário de Joaquim Fidélis mantinha-se da observação da experiência alheia.

No andamento da narrativa, as reações de Benjamin à leitura do diário do tio desdobram-se "de forma elíptica e fragmentária" (PIGLIA, 2004, p. 90), como espécie de segunda história do conto. Ele tinha começado com a voz embargada e defendia a exclusão de "alguma coisa, ou inconveniente ou demasiadamente particular" em contraposição aos amigos que desejavam a "impressão tipográfica" da obra de Joaquim Fidélis (ASSIS, 2008, p. 373).

As palavras "impressão tipográfica" (ASSIS, 2008, p. 373) conotam o desejo de publicação da parte dos amigos, mas também podem ser lidas como o desejo que estes têm de realizar uma leitura superficial dos escritos. O narrador diz que particularidades do texto tinham dado-Ihes "uma comichão de escândalo" (ASSIS, 2008, p. 373). Assim, eles se portam como uma horda de leitores vorazes, não no sentido de leitores contumazes, mas no sentido de leitores que querem devastar a escrita íntima de um homem que era considerado uma espécie de totem no círculo.

Diferentemente, Benjamin se portava como um leitor cauteloso, sensível e parcialmente ingênuo:

Uma vez só, Benjamin continuou a ler o manuscrito. Entre outras coisas, admirou o retrato da viúva Leocádia [...]

Benjamin ia lendo; de repente deu com o Diogo Vilares. [...]

A primeira sensação do Benjamin foi a do perigo evitado. Se o Diogo estivesse ali? Releu o retrato e mal podia crer; mas não havia negá-lo, era o próprio nome do Diogo Vilares, era a mesma letra do tio. E não era o único dos familiares; [...] (ASSIS, 2008, p. 374).

Após a leitura do retrato do Elias Xavier, Benjamin protesta: 
- Ora o tio Joaquim! exclamou Benjamin levantando-se. E depois de alguns instantes, reflexionou consigo: - estou lendo um coração, livro inédito. Conhecia a edição pública, revista e expurgada. Este é o texto primitivo e interior, a lição exata e autêntica. Mas quem imaginaria nunca... Ora o tio Joaquim!

E, tornando a sentar-se, releu também o retrato do Elias, com vagar, meditando as feições. Posto Ihe faltasse observação, para avaliar a verdade do escrito, achou que em muitas partes, ao menos, o retrato era semelhante. Cotejava essas notas iconográficas, tão cruas, tão secas, com as maneiras cordiais e graciosas do tio, e sentia-se tomado de um certo terror e mal-estar. Ele, por exemplo, que teria dito dele o finado? Com esta idéia, folheou ainda o manuscrito [...] (ASSIS, 2008, p. 375).

Por fim, o momento ansiado por Benjamin:

Benjamim, estupefato, deu enfim consigo mesmo. - "Este meu sobrinho, dizia o manuscrito, tem vinte e quatro anos de idade, um projeto de reforma judiciária, muito cabelo, e ama-me. Eu não o amo menos. Discreto, leal e bom - bom até a credulidade. Tão firme nas afeições como versátil nos pareceres. Superficial, amigo de novidades, amando no direito o vocabulário e as fórmulas" (ASSIS, 2008, p. 376).

Nota-se que este retrato é diferente dos outros. As semelhanças encontramse na brevidade, num elemento de descrição física e no apontamento de um defeito, o da superficialidade. Contudo, em sua tonalidade geral, ele é amável e afetivo, diferenciando-se dos outros. Aliás, embora ele descreva uma característica negativa, não a enfatiza.

Outra diferença reside na disposição gráfica do retrato na página. Os demais perfis são transcritos de forma destacada em relação ao corpo do texto, com uma formatação diferente. Este último, no entanto, aparece inserido no parágrafo iniciado pelo narrador em relação de continuidade gráfica. A diferença da disposição gráfica na página pode significar o diferencial da relação de Benjamin com o tio. Em oposição às relações afetivamente soltas (graficamente destacadas) com os outros personagens, a relação entre o sobrinho e o tio teria maior pertença e propriedade.

Ainda assim, o mal-estar de Benjamin persiste. Essas sensações, inclusive, potencializam-se, quando o personagem topa com o seu próprio retrato. Nesse momento, nós, leitores implícitos, somos surpreendidos por uma segunda história do conto: 
contemplar outra vez as suas feições. Contemplou-as; eram poucas, falhas, mas não pareciam caluniosas. Se ali estivesse um público, é provável que a mortificação do rapaz fosse menor, porque a necessidade de dissipar a impressão moral dos outros dar-Ihe-ia a força necessária para reagir contra o escrito; mas, a sós, consigo, teve de suportá-lo sem contraste. Então considerou se o tio não teria composto essas páginas nas horas de mau humor; comparou-as a outras em que a frase era menos áspera, mas não cogitou se ali a brandura vinha ou não de molde (ASSIS, 2008, p. 376).

O motivo do espelho surge novamente. Em "Galeria Póstuma", o espelho significa o duplo da tradição, que é incômodo, evocando igualmente problemas de constituição do sujeito. Isto porque a "sensação de um espelho" está vinculada não apenas à reprodução da imagem do personagem, mas também ao olhar de um outro sobre o sujeito - olhar este que participa, de maneira fundamental, em sua constituição. O tio é uma figura parental para Benjamin. Aquele personagem se encontra na rede de identificações que constituía o jovem como sujeito, segundo a fábula do conto. Lembremos, por exemplo, do detalhe do diploma que Benjamin devia ao tio pertencia à mesma área de conhecimento em que o pai vigário havia se formado, o direito.

Contudo, nessa passagem do conto, o olhar que estabelece a relação de fraternidade e de filiação entre os dois é colocado em xeque. De forma medusante, o sobrinho tem um acesso sem desvios ao olhar do outro, o tio. Olhar que, de longe, mostra-se mais amável do que nos demais retratos de familiares, evidenciando o afeto que possibilitava a identificação em curso entre os dois, mas, ao mesmo tempo, suspendendo-a. Ou seja, a evidência do olhar do tio amplifica-o e torna-o mortificador para Benjamin. Para o personagem leitor, o desenho verbal aparece-lhe como um choque da ordem do Real. No entanto, a composição de retratos pelo tio inscrevia-se num campo imaginário. Ainda assim, eles causam impacto porque eram inacessíveis aos outros personagens, dentro de um funcionamento social regulado pela hipocrisia. O abalo, por fim, remete à desconstrução imaginária da figura do tio que Benjamin deve realizar, a partir da leitura do diário.

Os retratos de pessoas que lhe são distantes surtem em Benjamin o efeito objetivo de fotografias. Os retratos dos familiares, por sua vez, causam-lhe "terror e mal-estar" (ASSIS, 2008, p. 375). O último retrato, por fim, causa-lhe a "sensação de um espelho" (ASSIS, 2008, p. 376), a saber, a sensação de um duplo incômodo, que muito custa em ser admitido. Para confrontá-lo, Benjamin precisa de um intervalo 
para mirar uma paisagem externa, a da chácara, pois parece que lhe é insuportável ver sua pessoa condensada em "poucas linhas" (ASSIS, 2008, p. 376). Nessa cena, o fato de o perfil verbal ser curto incomoda o personagem, embora o narrador tivesse antes reconhecido a brevidade como uma qualidade estilística (ASSIS, 2008, p. 374).

Há também contradição em aceitar a descrição. Aos olhos de Benjamin, as feições do retrato eram "falhas, mas não pareciam caluniosas" (ASSIS, 2008, p. 376). Ademais, o personagem cai num desamparo relativo à solidão. $O$ narrador comenta que se o rapaz tivesse um público, teria que elaborar uma reação ao escrito que dissipasse a impressão moral dos outros. Seria o possível uso de uma máscara? No fundo, a reação passaria pela insurreição contra uma conformação da figura paterna para o personagem.

Enquanto o retrato dos outros era "exímio" (ASSIS, 2008, p. 374) ou "semelhante" (ASSIS, 2008, p. 375), o seu parece-lhe "falho" (ASSIS, 2008, p. 376). Para Benjamin, apesar do desagrado na leitura dos demais retratos de familiares, é possível fazer uma releitura. No entanto, em relação ao seu próprio retrato, o retorno é impossível. Quando volta ao desenho de si, ele não relê, mas sim "contempla" a figura (ASSIS, 2008, p. 376). O perfil verbal traçado pelo tio, em suma, não pode recobrir o conceito que Benjamin tem de si. Ele não é um tipo apenas, assim, não se vê nesse formato. Benjamin é um personagem complexo porque, além de autocontemplativo, possui um mundo interior delineado que tende à individualização. Ele imagina, pondera, questiona e anseia, de forma a sugerir efeito de intimidade psicológica enquanto personagem.

Ademais, apesar de ter recebido do falecido um perfil bem mais afetuoso, considerando-se o desenho dos outros personagens, não é dessa forma que Benjamim recepciona seu retrato. Ele compara os retratos a trechos de frase "menos áspera" do diário do tio, mas não se questiona se elas vinham "de molde" (ASSIS, 2008, p. 376). A expressão "de molde" pode significar tanto "com propriedade", no sentido da adequação do texto, quanto a ideia de uma "matriz formadora", ou seja, como frases que se configuram, a partir de formas tipológicas tradicionais. Nesse sentido, o questionamento sobre as frases de molde significa também 0 questionamento do modelo de formação que o próprio Benjamin teve em seu tio.

Benjamin não mais cogita sobre a adequação e sobre os recursos de estilo do texto, pois está subjetivamente implicado na leitura do diário. No momento da leitura 
do seu próprio retrato, as categorias intelectuais e retóricas mostram-se insuficientes. O personagem cogita antes sobre o afeto do tio, ao escrever os perfis. A cogitação repercute em autoengano, pois levanta a hipótese de que o autor estivesse de mau humor na hora da escrita dos retratos.

O autoengano em Benjamin é alimentado pelo desejo de filiação em relação ao parente e pelo desejo de receber uma herança simbólica: "- Espero que os amigos do tio Joaquim serão também meus amigos, disse ele" (ASSIS, 2008, p. 373). Haveria, ademais, abertura para uma especulação sobre a possível filiação legítima de Benjamin em relação ao Joaquim Fidélis? Como se cogita, por exemplo, em "Um homem célebre", conto posterior, sobre o padre-pai de Pestana (ASSIS, 2008, p. 465). "Benjamin", aliás, significa "filho da felicidade" e "filho da mão direita". A viuvez de Joaquim Fidélis e a insistência em não se casar são descritas pelo narrador, de forma reticente. O diário não cita nada a esse respeito. De qualquer forma, o desejo de pertença em relação ao tio subjaz na composição do personagem Benjamin.

Portanto, na avaliação dos escritos, entra em cena a desconstrução de uma figura paterna. A feição na hora da morte que fora rearranjada pelas mãos do próprio Benjamin retorna como elemento que antes havia sido recalcado. A careta passa a ocupar a memória do tio impressa no rapaz. A expressão do rosto do falecido, investida da interpretação do sobrinho, será sombreada pelo sentido da ironia e do desprezo que se conformam na máscara original:

Para confirmar a conjectura, recordou as maneiras usuais do finado, as horas de intimidade e riso, a sós com ele, ou de palestra com os demais familiares. Evocou a figura do tio, com o olhar espirituoso e meigo, e a pilhéria grave; em lugar dessa, tão cândida e simpática, a que the apareceu foi a do tio morto, estendido na cama, com os olhos abertos, o lábio arregaçado. Sacudiu-a do espírito, mas a imagem ficou. Não podendo rejeitá-la, Benjamim tentou mentalmente fechar-Ihe os olhos e consertar-Ihe a boca; mas tão depressa o fazia, como a pálpebra tornava a levantar-se, e a ironia arregaçava o beiço. Já não era o homem, era o autor do manuscrito (ASSIS, 2008, p. 376).

Assim é que o homem cordial Joaquim Fidélis, apesar de escrever em vida, constitui-se como autor após a morte. O título "Galeria póstuma" propõe uma inversão do funcionamento da galeria tradicional de retratos que representam medalhões. No lugar deles, a leitura de Benjamin apreende, sobretudo, os retratos 
de homens do convívio familiar. A composição desses retratos desfaz, contudo, a mascarada pública e recorrente, apresentando figuras que são tracejadas como caracteres. No mais, o fato de essa galeria típica ser póstuma indica o ponto de vista da morte (PASTA JR., 2007), que se estabelece no momento de leitura. Ou seja, a "Galeria póstuma" não se forma totalmente na escrita, pois depende do passo relevante do leitor Benjamin para completá-la, segundo uma orientação subjetivamente implicada.

Aliás, a tipificação de Benjamin desenhada por Joaquim Fidélis como "bom", "de afeições", "crédulo", "superficial”, "amante de novidades" etc., por ironia, vinga na caracterização do personagem (ASSIS, 2008, p. 376). Benjamin sai de dentro da casca do tipo, expondo-se como personagem pessoa, em desamparo, órfão de pais e órfão do tio que morrera há pouco. Ele se encontra, principalmente, desamparado da imagem na qual investira em relação ao falecido, "tão cândida e simpática" (ASSIS, 2008, p. 376), que, no final do conto, passa a ser obliterada pela leitura do manuscrito.

Porém, mesmo que Benjamin seja um personagem que sai da tipificação em direção à composição de um personagem individual, ele reafirma a pertinência dos poucos traços desenhados no diário do falecido. Isto porque Benjamin rejeita a herança simbólica que o tio lhe passara em relação à dissimulação e à ironia nas relações. Justamente por ser "bom”, "de afeições", "crédulo" etc., Benjamin não pode ser irônico ou dissimulado.

No entanto, em 1884, o "naufrágio das ilusões" (ASSIS, 2008, p. 622) já era completo e Benjamin não sai ileso da "lição" (ASSIS, 2008, p. 375). Assim, o sobrinho dissimula para esconder os retratos dos cincos familiares. Os leitores retornam para continuar a leitura do diário de Joaquim Fidélis. Benjamin, contudo, simula circunlóquios com o intuito de despistá-los:

[...] Mas Benjamim tergiversava, dizia isto e aquilo, inventava pretextos; por mal de pecados, apareceu-lhe na sala, por trás deles, a eterna boca do defunto, e esta circunstância fê-lo ainda mais acanhado. Chegou a mostrarse frio, para ficar só, e ver se com eles desaparecia a visão. Assim se passaram trinta a quarenta minutos. Os cinco olharam enfim uns para os outros, e deliberaram sair; despediram-se cerimoniosamente, e foram conversando, para suas casas:

- Que diferença do tio! Que abismo! a herança enfunou-o! Deixá-lo! Ah! Joaquim Fidélis! Ah! Joaquim Fidélis! (ASSIS, 2008, p. 376) 
A herança que enfuna o herdeiro, segundo o olhar dos personagens tipológicos, é a herança do capital, que circunscreve o personagem como tipo. No entanto, a herança que enfuna Benjamin, a partir de seu ponto de vista peculiar, é a herança imaginária do escrito, que remonta, por sua vez, a um engenho velho. "A eterna boca do defunto" (ASSIS, 2008, p. 376) é aquela que não cessa de lembrar a expressão verbal de ironia.

No início da abordagem do conto, referi-me à nota de Histórias sem data escrita por Valentim Magalhães em 1884. Desde então, sabemos que a crítica machadiana modificou-se continuamente, chegando, com frequência, a leituras da obra opostas entre si. No momento contemporâneo ao do texto abordado, o crítico relacionava o livro de contos ao diário manuscrito de Joaquim Fidélis. Uma obra, a de Machado de Assis, contém outra, a do tio de Benjamin. Há semelhanças no uso de costumes retóricos que são compartilhados por uma e por outra obra. Magalhães retoma uma imagem de apelo melodramático formulada por Benjamin, não nos esqueçamos. No entanto, é possível que a associação de Magalhães tenha sido estabelecida não apenas em função da recorrência de alguns traços evidentes de estilo, mas também porque, assim como o Benjamin, os leitores supostos de Machado de Assis são necessariamente desbancados de suas categorias prévias e estáveis. 
'Cull roses while the Summer lasts, Too late 't will be in winter's blasts J. Bell (epígrafe de The Season, versão em língua inglesa da revista Die Modenwelt) 


\section{4. "Uma senhora" (1883)}

"Uma senhora" é outro conto enfeixado na quarta coletânea de Machado de Assis, ou seja, Histórias sem data, de 1884. O conto foi publicado inicialmente na Gazeta de Notícias, em outubro de 1883.

Como já citado, a recepção imediata de Histórias sem data dava continuidade ao diletantismo da crítica brasileira na década 1880. Um dos exemplos do diletantismo da crítica é a nota à publicação do livro, em 1884, na revista $A$ Estação. A nota é assinada pelo nome de Alzira C. (pseudônimo não identificado) e é escrita em forma de carta, destinada a Alice de Sá.

A carta tem um tom aparentemente descompromissado e apresenta uma ênfase na caracterização do feminino. Ou seja, há caracterização de uma leitora como tipo ideal pertencente ao público do livro. Há também caracterização metafórica do livro de contos como sendo um "grupo de moças" (C. Apud MACHADO, 2003, p. 150).

No contexto da revista $A$ Estação, o livro de Machado de Assis era recebido enquanto leitura de entretenimento ${ }^{59}$. Dessa forma, podemos observar que Alzira $\mathrm{C}$. recomendava Histórias sem data à amiga para que ela o lesse em "insípidas e abomináveis noites de hotel" (C. Apud MACHADO, 2003, p. 151).

No entanto, em trecho de acentuado "estilo divagante" (MACHADO, 2003, p. 150), ao comentar o pessimismo da obra, a carta de Alzira C. menciona questões que curiosamente se mostram relevante enquanto tema para o conto "Uma senhora":

Algumas linhas acima dei várias explicações ao pessimismo do autor, esquecendo-me que tenho 25 anos (juro-te que não tenho mais: não dês ouvidos ao Fernando, que é um caluniador), esquecendo-me de que estou nos primeiros capítulos e longe da longa ou dolorosa errata da vida.

Quem me diz a mim que daqui a muitos anos, minha boa Alice, demitida do prazer e da alegria por um ministro do tempo; quem me diz a mim que não aceitarei integralmente esta teoria, que hoje abomino?

${ }^{59}$ Cf. página 83 que cita o estudo de Ana Cláudia Suriani da Silva (2010), Machado de Assis's Philosopher or dog?. 
Pode ser; pode muito bem ser; mas até lá riamos! Como os ratos do "Conto alexandrino", que se viram livres dos filósofos, e enquanto não chegavam outros mais desumanos e mais cegos.

E não riamos só; leiamos as Histórias sem data, cujo título não mente, e que das nossas mãos passarão - sempre belas - às nossas filhas, e destas às nossas netas! (C. Apud MACHADO, 2003, p. 151).

Entra em questão na nota a idade da autora, que é jovem e associa o pessimismo do autor e da obra à velhice e experiência. Entram em cena também o status social da "senhora", a mulher de elite casada, e a expectativa da passagem das gerações. Ou seja, passar o livro às filhas e netas. Observemos que a inserção desses temas, assim como a caracterização dos contos como "grupo de moças" (C. Apud MACHADO, 2003, p. 150) possui relação direta com o público leitor feminino de $A$ Estação e com o ethos da revista.

O que podemos interpretar da parte final do comentário crítico de 1884 ? Embora o autor seja compreendido como um pessimista ${ }^{60}$, ainda se retrata um Machado de Assis inócuo ${ }^{61}$ cujas histórias passarão pelas mãos de um público que se manterá homogêneo, mantendo o status quo social, segundo as expectativas da leitora. Ou seja, na carta de Alzira C., as leitoras continuarão a ser as senhoras de elite, geração após geração, e as histórias sem data continuarão sempre belas.

Quando lemos o conto "Uma senhora" de Machado de Assis, por sua vez, percebemos o desenvolvimento dos mesmos temas relativos à idade e ao status social da mulher, mas de forma muito diversa e até oposta. A trama e o narrador incitam o leitor a especular sobre as motivações da personagem e a desconfiar delas dentro de um determinado funcionamento social.

No conto, a senhora que é a personagem principal não quer envelhecer e o texto é desenvolvido, a partir desse motivo. Por um lado, há ânsia pela juventude

\footnotetext{
${ }^{60} \mathrm{Na}$ mesma carta, lemos: "E, todavia, sou forçada a pôr aqui um reparo: há algum tempo, ou, falando bibliograficamente, há alguns volumes, o autor da Parasita Azul encontra no fundo de todas as taças uma especiaria, demasiado forte ou demasiado amarga, não sei, que o obriga a esboçar uma careta. Tédio, imaginação ou ciência última da vida?" (C. Apud MACHADO, 2003, p. 150). A expressão é retirada justamente do conto "Uma senhora": "D. Camila adorava a filha; saboreou-lhe a glória a tragos demorados. No fundo do copo achou a gota amarga e fez uma careta" (ASSIS, 2008, p. 399).

${ }^{61}$ Antonio Candido comentou a compreensão de Machado de Assis enquanto autor inócuo por parte da recepção crítica imediata: "O que não há dúvida é que essas primeiras gerações encontraram nele uma filosofia bastante ácida para dar a impressão de ousadia, mas expressa de um modo elegante e comedido, que tranqüilizava e fazia de sua leitura uma experiência agradável e sem maiores conseqüências" (CANDIDO, 2004, p. 19).
} 
inesgotável por parte da protagonista e, por outro, há o enredamento complexo entre vaidade e valores altruístas. Assim, lemos no primeiro parágrafo:

Nunca encontro esta senhora que me não lembre a profecia de uma lagartixa ao poeta Heine, subindo os Apeninos: "Dia virá em que as pedras serão plantas, as plantas animais, os animais homens e os homens deuses." E dá-me vontade de dizer-Ihe: - A senhora, dona Camila, amou tanto a mocidade e a beleza, que atrasou o seu relógio a fim de ver se podia fixar esses dois minutos de cristal. Não se desconsole, dona Camila. No dia da lagartixa, a senhora será Hebe, deusa da juventude; a senhora nos dará a beber o néctar da perenidade com suas mãos eternamente moças (ASSIS, 2008, p. 398).

O narrador abre o conto com a negativa absoluta de jamais encontrar dona Camila sem se lembrar da profecia da lagartixa ao poeta Heine. Na página do site machadodeassis.net, podemos localizar a citação na obra de Heine $A$ cidade de Lucca, em que, inclusive, não há alusão alguma à lagartixa ${ }^{62}$.

A inovação da lagartixa soa como chiste, logo no início, pela escolha de um animal de dimensões reduzidas, réptil e de aparência pegajosa, que fala como um profeta a Heine sobre a transformação das pedras em seres vivos, e esses em metamorfose chegando a deuses. Assim, "no dia da lagartixa" dessa estranha "evolução", dona Camila será Hebe, a deusa da juventude. Trata-se de um comentário jocoso do narrador que sugere o contrário, pois ridiculariza esse tipo de teoria evolutiva. É possível que mais uma vez a obra de Machado de Assis estivesse rebaixando o discurso cientificista em voga. Assim, o dia da lagartixa, além de cômico, é ilusório, bem como os deuses. Dessa forma, logo começa no conto um embate constante entre dona Camila e as gerações posteriores.

No início, d. Camila (cujo pronome de tratamento passa a ser abreviado) é descrita em seus atributos físicos belos e na sua habilidade ou "defeito de retardar os anos" (ASSIS, 2008, p. 398). Ou seja, d. Camila permanece na casa dos vinte ou dos trinta, pelo menos em aparência. Logo na passagem do segundo para o terceiro

\footnotetext{
62 "A frase é, de certo modo, uma adaptação de Machado, já que o texto de Heine não fala em "lagartixa"; a tradução literal do que diz Heine é: "As pedras se tornarão plantas, as plantas se tornarão animais, os animais se tornarão homens e os homens se tornarão deuses."; a referência está no livro "Reisebilder" ("Quadros de viagem"), da parte chamada "Die Stadt Lucca" ("A cidade de Lucca"), que está no volume 2. Heinrich Heine (1797-1856) foi um dos maiores autores do Romantismo alemão".

Disponível em: http://machadodeassis.net/dtb resposta contos. asp?Selromance $=\&$ Selconto $=245 \&$ Selcampo $=11 \&$ Sel

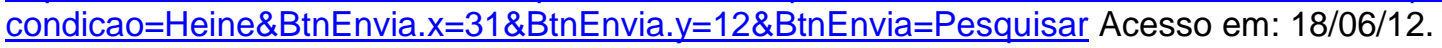


parágrafo, contudo, apresenta-se o conflito não apenas contra a passagem do tempo, mas também contra a filha da protagonista, Ernestina.

O conto desenvolve-se, portanto, tendo como dados a ânsia por juventude da parte de d. Camila e certo "orgulho" (ASSIS, 2008, p. 398) da personagem que se desdobra em inevitável rivalidade com Ernestina. A filha é referida pelo narrador do conto como "o fio [de cabelo] branco" (ASSIS, 2008, p. 399) metafórico de d. Camila.

O "orgulho", no caso, será um eufemismo encobridor do narrador para outros termos que seriam mais apropriados à personagem, ao longo do conto, como, por exemplo, egoísmo ou vaidade:

Resta dizer que era casada, que o marido era ruivo e que os dois amavamse como noivos; finalmente que era honesta. Não o era, note-se bem, por temperamento, mas por princípio, por amor ao marido, e creio que um pouco por orgulho (ASSIS, 2008, p. 398).

A ideia de gerações futuras é aterrorizante a $d$. Camila e por meio de "sensações" a personagem decide "adiar o neto" antes mesmo de a filha se casar:

D. Camila viu iminentemente o primeiro neto, e determinou adiá-lo. Está claro que não formulou a resolução, como não formulara a ideia do perigo. A alma entende-se a si mesmo; uma sensação vale um raciocínio. As que ela teve foram rápidas, obscuras no mais íntimo do seu ser, donde não as extraiu para não ser obrigada a encará-las (ASSIS, 2008, p. 399).

A personagem d. Camila passa, então, a tramar contra noivados ou casamentos, procurando falhas em pretendentes de Ernestina, até formular e repetir em voz alta para si mesma o "conceito" racionalizado de que "queria um genro que trouxesse à filha a mesma felicidade que o marido lhe deu" (ASSIS, 2008, p. 401).

O narrador do conto, por sua vez, por meio de insinuações e negativas irônicas, induz o leitor a especular sobre o egoísmo e a vaidade de d. Camila como preponderantes nas motivações da personagem, ao invés de um pretenso "sentimento materno".

Assim, ao protestar contra um noivo que seria "ministro de estrangeiros", lemos da parte de d. Camila: "- O quê? separar-me de minha filha? Não, senhor" (ASSIS, 2008, p. 400). Em seguida, lê-se o comentário do narrador:

Em que dose entrara neste grito o amor materno e o sentimento pessoal, é um problema difícil de resolver, principalmente agora, longe dos acontecimentos e das pessoas. Suponhamos que em partes iguais (ASSIS, 2008, p. 400). 
Igualmente, após o fim da "primeira aventura" (ASSIS, 2008, p. 400) de Ernestina, lemos o seguinte comentário do narrador:

D. Camila padeceu com o desgosto da filha; mas consolou-se depressa. Não faltam noivos, refletiu ela. Para consolar a filha, levou-a a passear a toda parte. Eram ambas bonitas, e Ernestina tinha a frescura dos anos; mas a beleza da mãe era mais perfeita, e apesar dos anos, superava a da filha. Não vamos ao ponto de crer que o sentimento da superioridade é que animava d. Camila a prolongar e repetir os passeios. Não: o amor materno, só por si, explica tudo. Mas concedamos que animasse um pouco. Que mal há nisso? Que mal há em que um bravo coronel defenda nobremente a pátria, e as suas dragonas? Nem por isso acaba o amor da pátria e o amor das mães (ASSIS, 2008, p. 400).

Percebemos nesse trecho o tema das motivações individuais inconfessáveis que são apresentadas encobertas por pretextos de aparência nobre ou socialmente aceitáveis, como ocorre com frequência em Machado de Assis. Nesse ponto, podemos reconhecer uma apropriação moderna que Machado empreendeu do pensamento filosófico de La Rochefoucauld para a figuração do interesse em sua obra. A epígrafe das máximas do moralista é a seguinte: "Nos vertus ne sont le plus souvent que des vices déguisés" (LA ROCHEFOUCAULD, 1961, p. 3) . $^{63}$.

A menção ao amor à pátria em "Uma senhora", por exemplo, lembra a fala da viúva Valéria de laiá Garcia. Esta, desejando distanciar o filho Jorge de Estela, a moça agregada da casa, decide enviá-lo à guerra do Paraguai e tenta justificar-se usando 0 argumento do amor à pátria. Assim, a personagem argumenta:

- Por que não? Eu creio que é chegado o momento de fazerem todas as mães um grande esforço e darem exemplos de valor, que não serão perdidos. Pela minha parte trabalho com o meu Jorge para que vá alistar-se como voluntário; podemos arranjar-Ihe um posto de alferes ou tenente; voltará major ou coronel. (...)

- (...) também a mim custaria a separação. Mas não se trata do que eu ou ele podemos sentir: trata-se de uma coisa mais grave - da pátria, que está acima de nós (ASSIS, 2008, p. 515).

O comentário do narrador sobre o "desfecho" é igualmente irônico: "Assim foi que de um incidente comparativamente mínimo resultara aquele desfecho grave, e de um caso doméstico saía uma ação patriótica" (ASSIS, 2008, p. 529-530). O personagem do romance que ouve Valéria, Luís Garcia, por sua vez, evidentemente

\footnotetext{
63 "Nossas virtudes não são o mais das vezes que vícios mascarados" (LA ROCHEFOUCAULD Apud BOSI, 2007, p. 192).
} 
não acreditava na justificativa pública e desejava descobrir "a mola secreta da ação daquela senhora" (ASSIS, 2008, p. 517). Embora no romance a questão seja mais pertinente ao rebaixamento da referência ao contexto histórico, que figura menos relevante do que a lógica familiar patriarcal, também entra em cena a questão da motivação da personagem Valéria, tal qual no conto "Uma senhora".

Voltemos, portanto, à personagem d. Camila e a suas motivações. Mesmo sendo Ernestina o fio de cabelo branco metafórico da mãe, o fio de cabelo branco literal da protagonista chega numa das passagens altas do conto, que é narrada quase como uma cena de horror, assim como o estranho familiar freudiano (unheimlich), já mencionado em relação ao conto "O espelho". Lembremos que o "estranho familiar" é, como na citação de Schelling, "tudo o que deveria ter permanecido secreto e oculto, mas veio à luz" (FREUD, 1976, p. 282), ou seja, o elemento íntimo que foi longamente recalcado. A passagem do conto é a seguinte:

Olhava para fora, olhava para o espelho. De repente, como se the surdisse uma cobra, recuou aterrada. Tinha visto sobre a fronte esquerda - um cabelinho branco. Ainda cuidou que fosse do marido; mas reconheceu depressa que não, que era dela mesma, um telegrama da velhice, que aí vinha a marchas forçadas. O primeiro sentimento foi de prostração. D. Camila sentiu faltar-Ihe tudo, tudo, viu-se encanecida e acabada no fim de uma semana (ASSIS, 2008, p. 401).

Importante mencionar que, antes desse trecho, d. Camila sentia uma relação identitária e plena com a paisagem da chácara verde, "uma recordação da vida anterior no mesmo útero divino" (ASSIS, 2008, p. 401), um recurso estilístico que ironiza motivos do Romantismo e também ironiza a ideologia do "amor materno".

No entanto, após o fio branco surdir como uma cobra, d. Camila olha para a filha, que entra no quarto com bilhetes de teatro, escondendo o cabelo e sentido "saudade" e "inveja", ao fitar a jovem. Depois ainda, ficando só, ela arranca o fio de cabelo e "deita-o à chácara", com citação de Shakespeare no conto - "Out damned spot! Out?" - ao que o narrador explica que no ânimo de d. Camila a "velhice era um remorso" e o cabelo branco uma mancha, uma "nódoa" (ASSIS, 2008, p. 401).

Nesse trecho, a citação de Shakespeare aparece na língua original em função do diálogo que Machado estabelecia com a obra do dramaturgo na composição de seus personagens. Ou seja, a citação direta reforça o vínculo (importante para Machado de Assis) entre a tradição shakespeariana e o imaginário moral na composição de personagens. A citação direta em inglês também aumenta o teor de 
dramaticidade da cena. Contudo, ao mesmo tempo, ela rebaixa o drama comezinho de d. Camila.

A personagem faz isso em vão, porque os fios brancos voltariam: "Mas se os remorsos voltam, por que não hão de voltar os cabelos brancos?" (ASSIS, 2008, p. 401). Com o terceiro fio branco aparece o terceiro pretendente da filha e Ernestina se casa. D. Camila aproveita ainda o matrimônio como um "grande cenário" para "pôr em relevo suas graças outoniças" (ASSIS, 2008, p. 401).

A protagonista tem um neto um ano depois. $O$ narrador comenta em discurso indireto livre:

D. Camila acostumara-se à ideia, mas era tão penoso abdicar, que ela aguardava o neto com temor e repugnância. Esse importuno embrião, curioso da vida e pretensioso, era necessário na terra? Evidentemente, não; mas apareceu um dia, com as flores de setembro (ASSIS, 2008, p. 402).

No fim do conto, lemos sobre certa tentativa de adaptação e reclusão de $d$. Camila em casa, que não se faz durar por muito tempo. O narrador comenta que não sendo a casa um mosteiro, ela rasga o ato de abdicação e volta ao tumulto (ASSIS, 2008, p. 402).

Lemos, então, nos dois últimos parágrafos do conto o ponto máximo de tensão do texto que figura d. Camila na rua com o neto. Nesses parágrafos, articulase o efeito de estranhamento e de arrebatamento do leitor por meio de insinuações do narrador de que a senhora, d. Camila, queria passar por uma senhora qualquer na rua não como avó da criança, mas como mãe, por repetidas vezes, encenando voltar no tempo uma geração:

Um dia, encontrei-a ao lado de uma preta, que levava ao colo uma criança de cinco a seis meses. D. Camila segurava na mão o chapelinho-de-sol aberto para cobrir a criança. Encontrei-a oito dias depois, com a mesma criança, a mesma preta e o mesmo chapéu-de-sol. Vinte dias depois, e trinta dias mais tarde, tornei a vê-la entrando para o bonde, com a preta e a criança. - Você já deu de mamar? dizia ela à preta. Olhe o sol. Não vá cair. Não aperte muito o menino. Acordou? Não mexa com ele. Cubra a carinha etc. etc.

Era o neto. Ela porém ia tão apertadinha, tão cuidadosa da criança, tão a miúdo, tão sem outra senhora, que antes parecia mãe do que avó; e muita gente pensava que era a mãe. Que tal fosse a intenção de $d$. Camila não o juro eu. ("Não jurarás", Mat. V, 34). Tão somente digo que nenhuma outra 
mãe seria mais desvelada do que d. Camila com o neto; atribuírem-Ihe um simples filho era a coisa mais verossímil do mundo (ASSIS, 2008, p. 401).

Assim, "Uma senhora", o título do conto, é altamente ambíguo. Ele pode fazer referência a uma senhora em número, ou seja, uma apenas, "tão sem outra senhora" (ASSIS, 2008, p. 401), que age por supressão da filha Ernestina, já que a rivalidade contra esta se dá pelo conto todo. O título pode também significar uma senhora anônima, ou seja, uma mulher qualquer detentora de certo status e papel social e que é vista em público como mãe de uma criança. Dessa forma, d. Camila deseja fazer-se observada e mantém o interesse na opinião fugaz dos passantes.

Ao invés de evoluir a Hebe, uma deusa, d. Camila permanece mortal. No entanto, ela se torna uma personagem rica em movimentos mentais no conto tal qual uma pessoa (enquanto categoria filosófica), conforme podemos depreender, a partir do estudo de José Luiz Passos (2007). Ou seja, d. Camila é estruturada como uma personagem complexa.

A protagonista mostra sua "evolução" no conto, indo de uma senhora particular ao desejo de parecer uma senhora anônima e mais jovem. Paradoxalmente, podemos interpretar que existe também a intenção da personagem em ser uma "senhora única", por meio da supressão de Ernestina.

Vale observar que ainda no anonimato da rua, d. Camila é peculiar, justamente porque constitui uma personagem de motivações recônditas em relação aos outros personagens do conto. Ela tem a dissimulação como prática. Dessa forma, possivelmente finge que o neto é seu filho ou gostaria que a multidão assim imaginasse.

Nesse ponto, notamos um dos temas recorrentes na obra de Machado que é o engodo de tomar por verdade (ou de comunicar como verdade) o que é apenas verossímil: "atribuírem-Ihe um simples filho era a coisa mais verossímil do mundo" (ASSIS, 2008, p. 402) ${ }^{64}$. Nesse sentido, podemos perceber como são especialmente irônicas as possibilidades de leitura da palavra "desvelada" no último parágrafo: "Que tal fosse a intenção de d. Camila não o juro eu. (“Não jurarás”, Mat. V, 34). Tão somente digo que nenhuma outra mãe seria mais desvelada do que d. Camila com o neto" (ASSIS, 2008, p. 402).

\footnotetext{
${ }^{64} \mathrm{Em}$ "Retórica da verossimilhança", Silviano Santiago analisa as implicações culturais do "tema do verossímil" em relação à presença bacharelesca e jesuítica na sociedade patriarcal brasileira (SANTIAGO, 2000).
} 
Assim, por um lado, nenhuma mãe seria tão cuidadosa quanto d. Camila. A afirmação é irônica já que a encenação exige cuidados exagerados e empostados com a criança. Por outro, nenhuma outra mãe seria mais desvelada que ela, caso se revelasse justamente o que foi escondido, ou seja, o dado da fábula de que, enfim, ela não é a mãe.

Em suma, d. Camila não é desvelada porque não possui zelo por terceiros, pelo contrário. Em significado diferente, porém, ela seria desvelada (descoberta) justamente porque, ao longo do conto, oculta suas motivações pautadas por orgulho (num sentido negativo), vaidade, egoísmo, ostentação, travestindo-as sob valores altruístas como a construção patriarcal e romântica do amor materno.

Ainda pensando na ideia do desvelamento, podemos observar que o narrador insiste em "revelar" a personagem, mas se exime da responsabilidade ou da determinação sobre esta. Assim, ele incita o leitor a interpretar por si as intenções de d. Camila: "Que tal fosse a intenção de d. Camila não o juro eu. ("Não jurarás", Mat. V, 34)."; (...) atribuírem-Ihe um simples filho era a coisa mais verossímil do mundo" (ASSIS, 2008, p. 401).

Os comentários irônicos do narrador revelam conteúdos turvos e publicamente insustentáveis nas motivações da personagem protagonista. No caso, o desejo de supressão do outro não pode ser declarado. No entanto, cabe ao leitor a decisão ética de escolher serem ou não serem essas as intenções de d. Camila. $O$ narrador não jura e a decisão de ler nas entrelinhas é passada para o leitor.

Assim, é feita a inserção do versículo do "Evangelho de Mateus", na interpelação ao leitor suposto. O versículo faz parte do sermão da montanha, que discorre justamente sobre a doutrina cristã, estabelecendo leis e condutas morais para a constituição de uma ética do cristianismo. Lemos no trecho do sermão que se refere aos juramentos:

33 Também ouvistes que foi dito aos antigos: Não jurarás falso, mas cumprirás para com o Senhor os teus juramentos.

$34 \mathrm{Eu}$, porém, vos digo: De modo algum jureis: Nem pelo céu, por ser o trono de Deus;

35 nem pela terra, por ser estrado de seus pés; nem por Jerusalém, por ser cidade do grande Rei;

36 nem jures pela tua cabeça, porque não podes tornar um só cabelo branco ou preto. 
37 Seja, porém, a tua palavra: Sim, sim; não, não; pois o que disto passar, vem do maligno (BÍBLIA, 1988, p. 9).

Além do chiste da presença do cabelo branco em versículo posterior, a citação remete o conto e suas questões mais centrais ao campo da discussão ética por meio de intertextualidade. Lembremos, por exemplo, que outros versículos do sermão da montanha são empregados de forma a dizer justamente o contrário em momentos cruciais de debates sobre ética na obra de Machado de Assis.

Assim ocorre nas Memórias Póstumas no episódio relativo à Eugênia. Cito a emenda de Brás Cubas: "Não desci e acrescentei um versículo ao Evangelho: Bem-aventurados os que não descem, porque deles é o primeiro beijo das moças. Com efeito, foi no domingo esse primeiro beijo de Eugênia (...)" (ASSIS, 2008, p. 667). Essa passagem é de grande importância nas Memórias, na qual figura a única personagem "honesta" do romance, Eugênia, além de haver uma abertura de possibilidade para Brás escolher pelo respeito à individualidade de terceiros. Um momento de inflexão, em que, no fim, Brás não opta honestamente, pelo contrário. Segundo Roberto Schwarz, esse momento do romance constitui uma "peripécia em branco" (SCHWARZ, 2000, p. 85-104).

De forma semelhante, também no conto "O enfermeiro", após o narradorprotagonista Procópio induzir o leitor que ele deveria sair ileso da culpa de ter matado seu antigo paciente, o coronel, de quem ele recebe uma herança, o personagem menciona:

Adeus, meu caro senhor. Se achar que esses apontamentos valem alguma coisa, pague-me também com um túmulo de mármore ao qual dará por epitáfio esta emenda que faço aqui ao divino sermão da montanha: "Bemaventurados os que possuem, porque eles serão consolados (ASSIS, 2008, p. 497).

Lembremos que também em Freud há a discussão do princípio do amor ao próximo no sermão da montanha - "Ama teu próximo como a ti mesmo" -, que contribui para se concluir o oposto, ou seja, a radicalidade do mal-estar civilizatório. Freud analisa o mandamento, revelando que ele esconde justamente a hostilidade humana na cultura:

A pista pode nos ser fornecida por uma das chamadas exigências ideais da sociedade civilizada. "Ama teu próximo como a ti mesmo", diz ela; é conhecida universalmente, sem dúvida mais velha que o cristianismo que a ostenta como a sua mais gloriosa reivindicação, mas decerto não é muito 
antiga; em tempos já históricos era ainda estranha à humanidade. Vamos adotar uma atitude ingênua diante dela, como se a ouvíssemos pela primeira vez. Não podemos então suprimir um sentimento de estranheza e surpresa [...] (FREUD, 2011, p. 54).

O quê de realidade por trás disso, que as pessoas gostam de negar, é que o ser humano não é uma criatura branda, ávida de amor, que no máximo pode se defender, quando atacado, mas sim que ele deve incluir, entre seus dotes instintuais, também um forte quinhão de agressividade. Em consequência disso, para ele o próximo não constitui apenas um possível colaborador e objeto sexual, mas também uma tentação para satisfazer a tendência à agressão, para explorar seu trabalho sem recompensá-lo, para dele se utilizar sexualmente contra a sua vontade, para usurpar seu patrimônio, para humilhá-lo, para infligir-lhe dor, para torturá-lo e matá-lo. Homo homini lupus [O homem é lobo do homem]; quem, depois de tudo o que aprendeu com a vida e a história, tem coragem de discutir essa frase? (FREUD, 2011, p. 57)

Voltando a "Uma senhora", enfim, a inserção de um mandamento do sermão da montanha também se dá de forma irônica. Isso ocorre porque o narrador é a instância que ajuda a enredar o campo das motivações da personagem, mas não se posiciona quanto a estas no fim do conto, conforme vimos nos trechos anteriormente citados.

O narrador desvela o processo de encobrimento que d. Camila tece, mas não assume a responsabilidade interpretativa por suas motivações. Ele, inclusive, contribui para tecer as motivações com o uso do discurso indireto livre e com a articulação de comentários irônicos e insinuantes. Assim, a interpretação final é jogada ao leitor que, por sua vez, é colocado num beco sem saída.

Se o leitor, por um lado, segue as insinuações do narrador e interpreta-as cruelmente, julgará a personagem por si próprio. Por outro lado, se simpatizar com d. Camila - lembremos a representação ideal da leitora (uma senhora) presente na nota crítica da Estação, citada no início do capítulo -, ele pecará não só por ler mal, como também pela perpetuação de gestos cotidianos de barbárie, que se dão sob o véu de um verniz civilizatório.

Há o sofrimento do envelhecimento de d. Camila, que, por sua vez, deseja suprimir Ernestina ou usar terceiros, fazendo-Ihes meros acessórios - o que se torna regra dentro de um contexto social simultaneamente escravocrata e capitalista - e, 
por fim (ou em primeiro lugar?), há o movimento de o narrador acuar o leitor (ou seria o movimento de deixá-lo à deriva?).

Já o autor implícito está por trás de todos os planos da narrativa e compõe personagens que fazem referência ao funcionamento não cartesiano, descentrado do sujeito. O autor-implícito é também responsável pelo mascaramento das motivações da personagem e pela articulação de um foco narrativo que insinua essas mesmas motivações. No fim, podemos interpretar uma espécie de denúncia, sob sete véus, da insustentabilidade de um projeto civilizatório nos moldes do iluminismo.

Pensando no aspecto formal do conto, lembremos que na "Filosofia da composição" de Poe a obra breve deve ser estruturada com vistas ao fim. O autor deve primeiro ter em mente o tema e qual efeito será visado no leitor, além da extensão e do tom do texto (POE, 2000, p. 37-51).

Por sua vez, Julio Cortázar, ao procurar as constantes do conto, cria metáforas para um gênero difícil ou impossível de ser definido. Dessas metáforas, gostaria de assinalar duas: a que compara o conto a "uma síntese viva ao mesmo tempo que uma vida sintetizada, algo assim como um tremor dentro de um cristal, como uma fugacidade numa permanência" (CORTÁZAR, 2006, p. 151); e a que compara o conto à foto, como um texto que necessariamente deva se expandir muito mais, como um "fermento que projete a inteligência e a sensibilidade [do leitor] em direção a algo que vai muito além do argumento visual ou literário contido na foto ou no conto" (CORTÁZAR, 2006, p. 152).

Por fim, Piglia, em suas teses sobre a duplicidade do conto, valendo-se da ideia de "iluminação profana", afirma que o conto deve revelar algo que estava oculto (assim como o conceito estético freudiano de estranho familiar), revelando "sob a superfície opaca da vida, uma verdade secreta" (PIGLIA, 2004, p. 94).

Pensar sobre o conto "Uma senhora" pode levar-nos a todas essas teorias. A trama é tecida, desde o título, visando ao fim. O efeito de estranhamento (horror) e de surpresa no leitor, em especial nos dois últimos parágrafos, também corresponde a essas reflexões teóricas.

O narrador nos diz que Dona Camila atrasou o relógio porque queria "ver se podia fixar esses dois minutos de cristal" (ASSIS, 2008, p. 398) que fazem referência ao tempo da juventude. Também o conto pode ser dois minutos de cristal (estrutura regular e tridimensional) que condensam em si a vida e seu tempo histórico. 
Assim, na "Advertência da Primeira Edição" de Histórias sem data, Machado de Assis coloca seus contos numa zona ambígua. Por um lado, o título da coletânea evoca a falta de marco temporal. Por outro, há uma afirmação do autor esclarecendo que os textos possuem data, mas tratam "de coisas que não são especialmente do dia" (ASSIS, 2008, p. 346). Ou seja, segundo a advertência machadiana, as histórias do livro simultaneamente têm data e não têm data.

Como poderíamos interpretar a advertência? Poderíamos dizer que por se circunscrever às limitações de composição do conto, fazendo-o contido e tensionado, e por se ater às suas determinações históricas, dá-se a abertura para questões mais amplas de ordem ética e estética?

Assim, no caso específico de "Uma senhora", a abertura do pequeno ao grande ocorre: a partir da condensação e da surpresa relativas à pessoa moral de uma única personagem, somos levados a questionamentos éticos e estéticos amplos, relativos a uma nova concepção de sujeito e de formação de personagem em literatura brasileira. 
"Observe how healthily -- how calmly I can tell you the whole story". "The tell-tale heart", Edgar Allan Poe 


\section{5. "O enfermeiro" (1884)}

"O enfermeiro" foi publicado pela primeira vez em 13 de julho de 1884 na Gazeta de Notícias, com o curioso título de "Coisas íntimas". Mais de dez anos depois, em outubro de 1895, ele seria republicado na coletânea Várias histórias.

O cenário da recepção já era diferente a essa altura, se compararmos a época de publicação deste livro de contos com o anterior, Histórias sem data, de 1884. A principal diferença dizia respeito não tanto a uma maior compreensão da obra, mas sim ao corpo mais sólido da crítica. Com a publicação de Quincas Borba, formava-se, de fato, a "primeira tríade" (GUIMARÃES, 2008, p. 267) de críticos que escreviam continuamente sobre a obra de Machado de Assis. Estes críticos eram Sílvio Romero, Araripe Júnior e José Veríssimo. Cito Hélio de Seixas Guimarães a respeito desse cenário:

O estranhamento e a percepção de um certo desajuste em relação às expectativas não se dissiparam nem mesmo quando a produção do escritor passou a ser acompanhada com regularidade pelos principais críticos literários do século XIX, duas décadas depois de Ressurreição. Isso se deu em 1892, imediatamente após a publicação de Quincas Borba em volume e com a entrada quase simultânea em cena de José Veríssimo e Araripe Júnior. A partir daí, ambos acompanharam de perto a produção do escritor. Cada um a seu modo, tanto Araripe como Veríssimo reagiram aos ataques de Sílvio Romero, que polarizou a recepção inicial com suas opiniões muito negativas a respeito do homem e da obra (GUIMARÃES, 2008, p. 277).

A recepção imediata de Várias histórias foi, portanto, relativamente mais vultosa. Houve resenhas de Olavo Bilac, Valentim Magalhães, Clovis Beviláqua, Magalhães de Azeredo, Graça Aranha e José Veríssimo. Ademais, dois anos depois, Sílvio Romero publicou Machado de Assis, estudo comparativo de literatura brasileira (ROMERO, 1992). Excetuando-se evidentemente o último crítico, as críticas foram, em geral, celebratórias e, notavelmente, os contos e romances como observação psicológica foram um dos tópicos mencionados com frequência. Assim, Olavo Bilac escreve:

Nas Várias histórias, como nos Papéis avulsos, como nas Histórias sem data, como no Brás Cubas, como no Quincas Borba, há aquele mesmo amor da psicologia e aquela fina ironia que fazem Machado ser, sobre um 
artista, um pensador para quem a alma humana não tem segredos (BILAC Apud MACHADO, 2003, p. 181).

Já numa resenha do Jornal do Commercio, observa-se o "disfarce" em Machado para "velar a fealdade" dos casos que repugnam, distanciando o autor, portanto, do naturalismo e de algumas vertentes da escola realista:

(...) Para ele o belo não é o repugnante, e os casos teratológicos da sociedade não the parecem ser os assuntos mais próprios do escritor que deve deleitar, ensinando.

Quando os encontra e os aproveita não é para agravar-Ihes a hediondez com certa psicologia de convenção para uso dos romancistas; sabe sempre velar a fealdade que arrojaria o leitor a enroupar na influência e no encanto do seu estilo as misérias do homem pecador (JORNAL DO COMMERCIO Apud MACHADO, 2003, p. 183)

Encontramos, ainda, nas diversas críticas de 1895 os seguintes termos e formulações: "complexa e inesgotável curiosidade que lhe desperta o animal humano" (MAGALHÃES Apud MACHADO, 2003, 168); "interesse moral do caso exposto" (MAGALHÃES Apud MACHADO, 2003, 168); "delicadíssimo estudo psicológico em que se reproduz a desigualdade na partilha dos dons" (MAGALHÃES Apud MACHADO, 2003, 187); "observações psicológicas" (BEVILÁQUIA Apud MACHADO, 2003, p. 188); "para quem o eterno feminino é um vasto elemento moral" (AZEREDO Apud MACHADO, 2003, p. 196); "o psicólogo em Machado de Assis reveste uma forma irônica, satírica, cruel" (ARANHA Apud MACHADO, 2003, p. 198); e "cenas com pretensões ao horrível" (ROMERO Apud MACHADO, p. 201), em que o horrível é entendido como tom da obra, em comparação a Poe e Baudelaire.

Contudo, ainda não encontramos grande expressão crítica em relação a "O enfermeiro". Desde a primeira recepção, a tendência que tem se desdobrado até o presente é a de se debruçar sobre outros contos de Várias histórias como "A cartomante", "Conto de escola", "A causa secreta" e "Uns braços".

Alfredo Pujol fez apenas um breve comentário em relação a "O Enfermeiro" em suas conferências. Assim, ele se pergunta: "Quem poderia condensar numa síntese a extrema finura psicológica do conto "O enfermeiro"?" (PUJOL, 2007, p. 152). Salvatore d'Onofrio, por sua vez, observaria o texto pelo viés da hipocrisia e da ingratidão (D'ONOFRIO, 1979, p. 152). E Lucia Serrano Pereira apresentaria em 
2008 uma interpretação pungente do conto, a partir de uma abordagem psicanalítica.

Na recepção imediata, houve um comentário de Magalhães de Azeredo em relação ao conto, que vale ser retomado por tocar diretamente no problema da formação dos personagens:

Por isso, os personagens de Machado de Assis são geralmente caracteres indecisos, hesitantes, atormentados pela moléstia da dúvida; incoerentes? contraditórios? de acordo; mas verdadeiros por isso mesmo. O zigue-zague está mais na lógica real que a linha reta; nada tão comum como a dualidade, a multiplicidade até de uma alma; algumas há de uma só peça; mas são tão raras. Também ninguém melhor que Machado de Assis acompanha e traduz as modificações lentas que sofre uma ideia até tornarse volição e ato. Vede o caso dos "cinco contos de réis" no Brás Cubas, o da Atalaia com o Rubião de Quincas Borba, e ainda o estudo magnífico do Enfermeiro nas Várias histórias (AZEREDO Apud MAGALHÃES, p. 193).

A observação da tradução e de modificações lentas de uma ideia até sua manifestação em volição ou ato é um ponto fundamental a ser discutido. Esse ponto possui relação com um movimento abordado por José Luiz Passos de capacidade de análise e de imaginação dos personagens machadianos que justamente por seus meios de raciocínio e de fantasia configuram-se como pessoas na ficção.

Há outro elemento central presente em "O enfermeiro", que se vincula aos devaneios analíticos do personagem, mas que se manifesta de forma diversa. Tratase do poder retórico e argumentativo do narrador do conto, característica que nos remete a outros narradores complexos em primeira pessoa da obra de Machado de Assis.

No conto, conhecemos a história de Procópio que se diz "desenganado" (ASSIS, 2008, p. 492), esperando a morte em breve. Ele dá a entender, ao escrever seu caso, que oferecerá ao "senhor", que é um leitor referido (PEREIRA, 2008, p. 164), uma espécie de retrato moral, já que lhe dará um "documento humano" (ASSIS, 2008, p. 492).

O tempo do caso que ele conta remonta a 1860, numa vila isolada, também no interior, como em "O espelho". Sendo anteriormente "teólogo" (na verdade, copista) em Niterói, Procópio é convidado por um vigário e pelo padre com quem trabalhava para "servir" (ASSIS, 2008, p. 492) de enfermeiro ao coronel Felisberto, que padecia de um "rosário" (ASSIS, 2008, p. 493) de moléstias. A partir dessa 
apresentação, entendemos que Procópio era um homem livre pobre, pois dependia das cópias de estudos de teologia para que o padre lhe cedesse moradia. Aceitando o trabalho e chegando à vila, porém, ele recebe más notícias quanto ao seu futuro paciente, que é mal falado por todos.

No início, a relação com o coronel foi relativamente tranquila, mas este era sádico, motivo pelo qual não se relacionava bem com nenhum dos enfermeiros, e esses não permaneciam no posto. Uma série de insultos do coronel é aturada por Procópio que, em três meses, decide deixar o lugar e voltar para a corte, mas permanece por algum período.

Um dia, depois de acessos de raiva, o coronel acorda Procópio, que tinha dormido distraidamente, gritando e jogando-lhe uma moringa no rosto. "Estremunhado" (ASSIS, 2008, p. 494), o enfermeiro não se controla e esgana o paciente. O que se passa depois do crime, além do delírio e do remorso, é a tentativa de Procópio de esconder provas. O inusitado, contudo, é que não tendo mais relações, o coronel havia deixado sua herança a Procópio. A princípio, aceitar os bens repugna o protagonista, que pensa em doá-los. No entanto, quando Procópio toma posse deles, ele não apenas muda de ideia, como também passa a argumentar a seu favor na narração, anulando a culpa do crime.

No quadro geral do conto em que Procópio tenta desfazer-se da culpa do assassinato, alguns detalhes chamam atenção como "vestígios" ou "indícios" na narrativa. O tratamento do coronel em relação ao nome de Procópio é um deles porque faz referência à escravidão:

Em seguida perguntou-me pelo nome: disse-lho e ele fez um gesto de espanto. Colombo? Não, senhor: Procópio José Gomes Valongo. Valongo? achou que não era nome de gente, e propôs chamar-me tão-somente Procópio, ao que eu respondi que estaria pelo que fosse do seu agrado. Conto-lhe esta particularidade, não só porque me parece pintá-lo bem, como porque a minha resposta deu de mim a melhor ideia ao coronel [...] (ASSIS, 2008, p. 493).

Valongo "não era nome de gente", na visão do coronel, porque era também o nome do mercado de escravos do Rio de Janeiro, que funcionou principalmente entre 1811 e 1831 e recebeu 1 milhão de africanos, criado com o pretexto de afastar o tráfico do Paço, após a transferência da corte para o Brasil (HAAG, 2011). Assim, a melhor impressão que o coronel teve de Procópio em função de esse concordar 
com ele (apesar da violência simbólica de anular seu sobrenome) e o dado de esta particularidade "pintá-lo bem" caracterizam o personagem em função de um perfil de senhor de escravos.

O trecho seguinte que descreve o coronel lembra-nos, por exemplo, o capítulo "O menino é pai do homem" (ASSIS, 2008, p. 638), das Memórias Póstumas. Aliás, o período histórico dos dois personagens, de Brás e do coronel Felisberto, coincide em parte, pois ambos morrem na década de 1860 com idade próxima aos sessenta anos. Cito o conto: "Tinha perto de sessenta anos, e desde os cinco toda a gente Ihe fazia a vontade. Se fosse só rabugento vá; mas ele era também mau, deleitavase com a dor e a humilhação dos outros" (ASSIS, 2008, p. 493).

Lucia Serrano Pereira analisou, sobretudo, as inversões e descontinuidades no conto. Assim, Pereira observa que, num primeiro momento, Procópio é submisso aos abusos do coronel, mas com a virada da narrativa, ele passa a ser justamente 0 maior "gatuno" que passou pelo caminho deste, ou seja, o que o matou e ficou com sua herança. Já o delírio de Procópio e o momento em que se arrepende do gesto tocam o descontínuo por excelência, que é o enfrentamento da morte: "É o momento da saída do fascínio da paixão - do ódio, para a aparição da descontinuidade - a morte" (PEREIRA, 2008, p. 168).

Nesse sentido, a crítica viabiliza a aproximação entre a obra de Machado de Assis e a teoria psicanalítica. Assim, um dos objetivos de sua tese é depreender nos contos momentos em que noções de um sujeito estável (conforme inscrito na filosofia do sujeito) são abaladas. Esses momentos têm relação com experiênciaslimite, e o tratamento desses temas no conto adiantaria em larga medida a presença da subjetividade moderna em literatura brasileira. Pereira afirma:

As "passagens" em questão são as que nos remetem às descontinuidades fundamentais da subjetividade; descontinuidades que podemos situar como interrogantes da situação humana - o sexual (a posição de cada um, homem ou mulher, frente ao desconhecido do outro sexo) e a morte/origem, que apontam o limite, a finitude. Essas descontinuidades, se assim podemos nomeá-las, foram também aquelas que interrogaram Freud, em torno das quais desenvolve as questões centrais da sua obra; passagens relativas aos elementos fantasmáticos da subjetividade que o escritor recolhe do imaginário social; passagens, no contexto machadiano, de profundas mudanças no cenário social, político e cultural, no âmbito da entrada na modernidade que marca o tempo e o contexto onde se inscreve 
sua ficção (do qual "Capítulo dos chapéus" é exemplar) (PEREIRA, 2008, p. 17).

Em “O enfermeiro", essa passagem é não apenas o descontínuo da morte, como também a inversão do discurso de Procópio. Fazendo referência a Tales Ab'Sáber, a crítica observa a questão do sentido unidimensional do gozo permitido ao papel do senhor escravocrata. No contexto brasileiro do 19, segundo Ab'Saber, a lei simbólica e a alteridade não representam instâncias estabelecidas na constituição do sujeito, o Outro é esvaziado e há impossibilidade de estruturação da cultura (AB'SABER, 2007, p. 281). Dessa forma, a culpa não advém da quebra de uma lei simbólica ou do desrespeito à alteridade, mas sim das negociações do narcisismo (PEREIRA, 2008, p. 171-172). Ou seja, segundo Pereira, ao herdar, Procópio assimila traços do papel senhorial, o seu gozo passa a estar acima da lei e deixar de desfrutar a herança é o que Ihe causaria culpa (PEREIRA, 20088, p. 17).

Portanto, Pereira observa a inversão maior no conto, que é a inversão retórica, por meio da qual Procópio investe no "aliciamento" do "senhor", este outro, que está supostamente lendo a história. Afinal, argumenta, ele mesmo foi vítima das circunstâncias e matou sem querer (o que é verossímil), "para se defender" (o que é improvável dada a descrição do personagem coronel, senil e doente), mas também porque era alvo de sadismo. Na inversão retórica do narrador-protagonista, o "crime" vira "luta".

Felisberto havia recalcado e discriminado o nome Valongo, desejando tratar seu enfermeiro por Procópio, grande ironia, já que o nome de origem grega quer dizer "progresso" (AZEVEDO, 1993, p. 492), o que progride, justamente o que acontece com o protagonista, mas com grande custo para o coronel.

Assim, devemos analisar as especificidades de Procópio como narrador e como personagem, nas quais entra a questão do ocultamento deliberado. Lembremos que o primeiro título do conto era "Coisas íntimas", o que por si só constitui um problema. Ademais, há uma forma de indução no conto, uma vez que este pede posicionamento e interpretação da parte do leitor. Não sem motivo a primeira frase é uma pergunta dirigida ao leitor e a primeira preocupação de Procópio é que se guarde segredo da história até sua morte:

Parece-lhe então que o que se deu comigo pode entrar numa página de livro? Vá que seja, com a condição única de que não há de divulgar nada antes da minha morte. Não esperará muito, pode ser que oito dias, se não for menos; estou desenganado (ASSIS, 2004, p. 492) 
Já enquanto personagem, após o crime, as deliberações e motivações ressaltadas em Procópio circulam pela culpa de ter assassinado o coronel, mas mesmo nesse instante da história, o impulso seguinte (e o que permanecerá) é o de esconder as evidências:

(...) cheguei a pensar na fuga; mas era confessar o crime; e ao contrário, urgia fazer desaparecer os vestígios dele (ASSIS, 2008, p. 494).

Vi no pescoço o sinal das minhas unhas; abotoei alto a camisa e cheguei ao queixo a ponta do lençol (ASSIS, 2008, p.494).

Eu mesmo amortalhei o cadáver, com o auxílio de um preto velho e míope (ASSIS, 2008, p. 494).

A passagem da meia escuridão da casa para a claridade da rua deu-me grande abalo; receei que fosse então impossível ocultar o crime (ASSIS, 2008, p. 496).

Cheguei a supor que fosse uma cilada [o testamento]; mas adverti logo que havia outros meios de capturar-me, caso o crime estivesse descoberto (ASSIS, 2008, p. 496 [grifo meu]).

Pensei nisso [na herança] três dias, e esbarrava sempre na consideração de que a recusa podia fazer desconfiar alguma coisa (ASSIS, 2008, p. 496 [grifo meu]).

Apesar da descrição das reações iniciais do personagem - entrar em choque com o ocorrido, delirar, sentir-se perseguido, esconder o crime pelo medo da punição -, há uma face posterior na sua composição, justamente a que muda com a herança, como vimos acima em relação à crítica de Lucia Serrano Pereira.

O relato dos momentos iniciais é envolto em culpa e fixação no assassinato. Contudo, após o recebimento dos bens, as relativizações da lei e do ato entram em cena. Logo após a notícia da carta do testamento, Procópio considera doar o espólio, a volta à vila ainda revive o cenário do crime com seu terror, mas o personagem não tardaria em mudar de opinião e ter novas "ideias fixas":

Crime ou luta? Realmente, foi uma luta, em que eu, atacado, defendi-me, e na defesa... Foi uma luta desgraçada, uma fatalidade. Fixei-me nessa idéia. E balanceava os agravos, punha no ativo as pancadas, as injúrias... Não era culpa do coronel, bem o sabia, era da moléstia, que o tornava assim rabugento e até mau... Mas eu perdoava tudo, tudo... O pior foi a fatalidade daquela noite... Considerei também que o coronel não podia viver muito mais; estava por pouco; ele mesmo o sentia e dizia. Viveria quanto? Duas semanas, ou uma; pode ser até que menos. Já não era vida, era um molambo de vida, se isto mesmo se podia chamar ao padecer contínuo do 
pobre homem... E quem sabe mesmo se a luta e a morte não foram apenas coincidentes? Podia ser, era até o mais provável; não foi outra cousa. Fixeime também nessa idéia... (ASSIS, 2008, p. 496 )

Ler esse parágrafo ao inverso é um dos exercícios para perscrutar as intenções de Procópio como narrador e personagem. Primeiramente, ele se diz em luta, pois foi atacado e, por uma fatalidade, teve que se defender. Ou seja, some das considerações o que é descrito anteriormente: o coronel delirava e, mesmo tendo jogado a moringa, foi Procópio quem lhe atacou, mesmo que sem premeditação. Depois, considera a culpa do coronel, dizendo perdoá-lo e considerando que ele estava já morrendo, sumindo também do horizonte o dado de que, apesar da violência do coronel, é o próprio personagem que insiste em ficar no posto de enfermeiro e que, no fim, assassina o doente.

Ademais, as negativas parecem afirmar justamente o seu contrário: era culpa do coronel; não fosse seu sadismo e suas atitudes insuportáveis, Procópio não o teria atacado; o coronel podia viver mais; era vida ainda, o bastante pelo menos para dar bengaladas, jogar pratos, moringas e proferir injúrias, mas não o bastante para se defender de uma esganadura; era improvável que alguma causa natural da morte coincidisse com o momento do assassinato. Assim, "negar é ainda afirmar" (ASSIS, 2008, p. 447), como lemos em "A cartomante".

Dessa forma, entra em questão não apenas a autocrítica do personagem Procópio, nos movimentos de sua consciência, como também a dissimulação. Dissimulação num primeiro sentido porque ele quis fugir da punição, fazendo assim esforços para que ninguém descobrisse as provas. Contudo, há também a dissimulação da motivação subsequente, que é ficar com a herança. Para tanto, é necessária uma revisão da cena do crime e o convencimento de si mesmo e do leitor de que este foi uma "luta".

Nesse ponto, podemos retomar a observação citada acima da recepção imediata de Magalhães de Azeredo, ou seja, que os personagens de Machado são contraditórios, movimentam-se em zigue-zague, e que há um longo caminho entra a concepção de uma ideia e suas transformações até a expressão delas em volição e ato. Azeredo citaria a esse respeito não apenas "O enfermeiro", como também o episódio dos cinco contos de réis em Brás Cubas.

José Luiz Passos também destacou esse episódio. Ele cita a lei da equivalência das janelas criada por Brás, segundo a qual um ato digno compensaria 
outro reprovável, mantendo uma espécie de "equilíbrio da pessoa moral". Assim, devolvendo uma meia dobra encontrada, Brás compensa a culpa de ter valsado com Virgília, "consequentemente", estando compensado, poderia manter para si os cinco contos de réis encontrados depois. Nessa segunda ação, que é recôndita, prevalecem os esforços do protagonista para que os outros personagens não descubram seus gestos e a articulação de justificativas para seus atos:

[...] O tratamento minucioso na composição das motivações dos seus personagens garante aos seus heróis pela primeira vez na nossa literatura, a gravidade da autocrítica. Tais heróis são capazes de decompor e mascarar suas motivações mais íntimas; eles possuem a capacidade de se colocar na posição de outros personagens, de perceber juízos contrários nas decisões mais harmoniosas, e não raro, de deliberar e agir a partir de contradições que os demais personagens não têm sequer a percepção (PASSOS, 2007, p. 110).

Passos observa, ademais, que a inclusão do leitor no tecer do juízo moral sobre as motivações dos personagens e do narrador é um dado da "fase realista" de Machado de Assis (PASSOS, 2007, p. 110). O crítico analisa a implicação do leitor, sobretudo, no episódio do vergalho nas Memórias Póstumas (PASSOS, 2007, p. 127-130).

Em "O enfermeiro", observamos a problemática da implicação do leitor. O Procópio que narra a história é um senhor doente, como antes era o coronel e, dessa posição, ele dialoga com o leitor. Por estar moribundo, ele também faz referência à tradição dos narradores machadianos que narram, a partir "do ponto de vista da morte"65. O "ponto de vista da morte" significa que o narrador está morto de fato, no momento da enunciação, caso de Brás Cubas, ou que evanesce do relato como, por exemplo, Jacobina. Ademais, muitos são os exemplos de fontes de relatos que guardam relação com o fúnebre como os contos "Frei Simão" e "Galeria Póstuma", entre outros.

\footnotetext{
65 "La structure dont il s'agit ici, je l'appelle, en ce qui me concerne et depuis longtemps, le point de vue de la mort. Réduite à son aspect le plus élémentaire, elle consiste à raconter une histoire ou à développer un récit à partir de la mort du narrateur même ou, en l'absence de celui-ci, comme c'est le cas pour le théâtre "dramatique" et, le plus souvent, aussi le cinéma, il s'agit de se developper la narration à partir de la décomposition de la conscience même qui fournit les donnés essentielles du récit. (...)" (PASTA JR., 2007, p. 157).
} 
A condição dos narradores ou das fontes pretensamente póstumas incomodou, por exemplo, o "antimachadiano"66 Sílvio Romero que, talvez pelo antagonismo, tenha captado elementos centrais da obra de Machado:

Machado de Assis, de algum tempo a esta parte, tem revelado certo gosto em fazer espírito, em arriscar sua pilhéria, seu bon mot, e tem procurado encapar o espírito numas atitudes filosofantes e numas roupagens esquisitas de missionário fúnebre. É por isso que quase todos os seus contos e romances são ultimamente umas histórias de papéis velhos, de memórias póstumas, de diários de suicidas, de sacristães que deixaram narrativas, de velhos peraltas que escreveram recordações etc. etc. $O$ artifício é evidente, a macaqueação de Sterne, por exemplo, é palmar (ROMERO, 1992, p. 202-203)

Portanto, estando perto de morrer, contar o crime e pedir perdão é um modo de expiar a culpa por meio da narrativa? Se no fim da narração, Procópio anula retoricamente essa culpa, por que o fazer? O narrador precisa convencer o leitor de que foi vítima ao invés de assassino? Ou, ainda segundo a interpretação de Lucia Serrano Pereira, o narrador Procópio precisa estabelecer um pacto com o leitor, chamá-lo para cúmplice, segundo uma "lei particular brasileira", na qual o gozo unimendisional está acima da Lei (PEREIRA, 2008, p. 172)?

Pensando nessas questões, podemos lembrar também de um narrador posterior a "O enfermeiro", que é Dom Casmurro. Hélio de Seixas Guimarães analisa que a figura do leitor nesse romance é colocada numa posição central de intérprete e, justamente porque o narrador visa à sua persuasão, o diálogo com o leitor deve necessariamente mover a empatia deste. Cito:

Enquanto em Brás Cubas e Quincas Borba o tom jocoso da narração convida ao distanciamento em relação aos fatos narrados, em Dom Casmurro a nostalgia melancólica apela à empatia do leitor. Ao mesmo tempo em que o narrador Bento Santiago procura convencer-nos da sua versão do ocorrido, ele vai deixando pelo caminho falsas pistas que possibilitam explicações divergentes das suas, constituindo-se em iscas para enredar o leitor no campo ficcional (GUIMARÃES, 2008, p. 215).

Guardadas as especificidades desse intrincado romance e a implicação de seu leitor na narrativa, alguns dos elementos analisado por Hélio Guimarães em relação a Dom Casmurro podem ser produtivos para a leitura de "O enfermeiro".

\footnotetext{
66 "Em 1888, [Sílvio Romero] excluiu Machado de Assis da sua História da literatura brasileira, e, em 1987, publicou a súmula do antimachadianismo em Machado de Assis: estudo comparativo de literatura brasileira, o primeiro e único livro dedicado ao autor em vida" (GUIMARÃES, 2008, p. 277).
} 
Assim, percebemos no conto que Procópio precisa convencer o leitor de sua versão. Ou seja, precisa convencer que é inocente. A dissimulação não se dá apenas no plano do personagem, mas também no plano do narrador.

Dessa forma, podemos observar o cálculo da narração de "O enfermeiro" nos seguintes detalhes: o interesse em persuadir o leitor é patente nas várias interpelações feitas; há a consideração da minimização do relato central, ou seja, Procópio considera que poderia muito bem contar qualquer outro caso ou mesmo sua vida inteira, mas se fixa no ponto do crime; há intencionalidade no contar da história, assim, por exemplo, o vocábulo "luta" é antecipado já na descrição da cena do assassinato; há, ademais, a constante referência a relato de terceiros como testemunho da crueldade do coronel. Cito alguns trechos do conto:

(...) Não tive tempo de desviar-me; a moringa bateu-me na face esquerda, e tal foi a dor que não vi mais nada; atirei-me ao doente, pus-lhe as mãos ao pescoço, lutamos, e esganei-o (ASSIS, 2008, p. 494 [grifo meu]).

Outro fenômeno interessante, e que talvez lhe possa aproveitar, é que, não sendo religioso, mandei dizer uma missa pelo eterno descanso do coronel (ASSIS, 2008, p. 494 [grifo meu]).

E referiam-me [os moradores da vila] casos duros [sobre o coronel], ações perversas, algumas extraordinárias. Quer que Ihe diga? Eu, a princípio, ia ouvindo cheio de curiosidade; depois, entrou-me no coração um singular prazer, que eu sinceramente buscava expelir. E defendia o coronel, explicava-o, atribuía alguma coisa às rivalidades locais; confessava, sim, que era um pouco violento... Um pouco? Era uma cobra assanhada, interrompia-me o barbeiro; e todos, o coletor, o boticário, o escrivão, todos diziam a mesma coisa; e vinham outras anedotas, vinha toda a vida do defunto. Os velhos lembravam-se das crueldades dele, em menino. E o prazer íntimo, calado, insidioso, crescia dentro de mim, espécie de tênia moral, que por mais que a arrancasse aos pedaços recompunha-se logo e ia ficando (ASSIS, 2008, p. 497 [grifo meu]).

Pode ser que eu, involuntariamente, exagerasse a descrição que então Ihes fiz; mas a verdade é que ele devia morrer, ainda que não fosse aquela fatalidade... (ASSIS, 2008, p. 494 [grifo meu]).

Dessa forma, Procópio, ao mesmo tempo em que narra com terror sua história e se diz vítima das circunstâncias, deixa indícios do contrário. Assim, ele faz uma insistente caracterização da crueldade do coronel. Tem motivações para anular o remorso e entrar em posse da herança. Procópio tem também o "prazer insidioso" em escutar como outros falam mal do coronel. 
Nesse sentido, nas duas interlocuções que emolduram o texto, lemos os pedidos mais importantes de Procópio ao leitor. No primeiro parágrafo, como visto acima, Procópio pede sigilo e pergunta se seu caso é memorável a ponto de entrar num livro. Logo em seguida, contudo, ele pede perdão pela história que contará, faz referências ao grão-mogol e aos macabeus, dizendo reservar exclusivamente ao senhor leitor os seus sapatos de defunto, se ele os quiser. Cito:

Adeus, meu caro senhor, leia isto e queira-me bem; perdoe-me o que the parecer mau, e não maltrate muito a arruda, se the não cheira a rosas. Pediu-me um documento humano, ei-lo aqui. Não me peça também o império do grão-mogol, nem a fotografia dos macabeus; peça, porém, os meus sapatos de defunto e não os dou a ninguém mais (ASSIS, 2008, p. 492).

E no fim do conto:

Adeus, meu caro senhor. Se achar que esses apontamentos valem alguma coisa, pague-me também com um túmulo de mármore, ao qual dará por epitáfio esta emenda que faço aqui do divino sermão da montanha: "Bemaventurados os que possuem, porque eles serão consolados" (ASSIS, 2008, p. 497).

Lucia Serrano Pereira analisou as referências ao grão-mogol e aos macabeus em sua tese, citando que o primeiro era um município mineiro, onde houve exploração de diamantes no fim do século 18, atraindo aventureiros (PEREIRA, 2004, p. 170). Por relação aos macabeus, Pereira se refere ao livro II, numa passagem em que se descobre, após a morte de soldados do exército de Judas, o macabeu, o significado oculto destas. Ou seja, eles haviam morrido por portarem objetos vetados que cultuavam aos ídolos de Jâmnia. Cito: "Macabeus - 42: "Bendiserram todos a ação do Senhor, o justo Juiz que torna manifesta as coisas ocultas" (PEREIRA, 2008, p. 170)

Na página machadodeassis.net, há também outra referência:

Grão-Mogol é o nome dado aos soberanos do império fundado no norte da Índia pelos mongóis, no século XVI; em 1877, estreou em Marselha uma ópera bufa intitulada "Grand Mogol", de Henri Charles Chivot e Henri Alfred Duru $^{67}$.

O que entra em questão no segundo parágrafo do conto é que o narrador não cederá ao leitor o grão-mogol, muito possivelmente pela conotação de riqueza 
material implicada (tanto na referência brasileira, quanto na referência original indiana), nem o retrato dos macabeus. Se seguirmos a interpretação de Pereira quanto aos macabeus, a fala de Procópio pode significar que ele não cederá facilmente o que seu relato contém de íntimo. Assim, mesmo que a narrativa se desdobre sobre suas motivações, ele não cederá de todo seus motivos recônditos. Ou seja, decidir se o que Procópio cometeu foi crime ou luta será responsabilidade do leitor. Ainda em outro sentido, podemos interpretar, segundo uma conotação religiosa, que não está ao nosso alcance acusá-lo. Ou seja, apenas num plano superior, Procópio poderia ser julgado - o Senhor espiritual é o único "justo Juiz" que pode desmascarar o oculto.

No entanto, Procópio promete ceder a esse leitor seus sapatos de defunto. Por que mencionar os sapatos, se poderia mencionar qualquer outro espólio? Muito provavelmente porque, além da alusão ao Valongo, os sapatos também fazem referência à escravidão. Como estigma e marca distintiva contra fugas, os escravos não usavam sapatos (ALENCASTRO, 1997, p. 78-83). Outro dado que remete ao genocídio do Valongo, aliás, é que os africanos ali mortos, dadas as péssimas condições, eram enterrados indistintamente numa vala (HAAG, 2011). Não havia qualquer possibilidade de ritos fúnebres. Com os sapatos de defunto, Procópio alude cruelmente a um elemento de estigma na vida e na morte.

O detalhe da oferta dos sapatos fúnebres, portanto, opera como mais um indício da intencionalidade do narrador-protagonista. Ou seja, se pode ceder seus sapatos de defunto, mas não pode ceder riqueza, nem suas motivações ocultas, isso quer dizer que Procópio possui uma visão fria da morte, o que contradiz a referência religiosa aos macabeus. Quando o coronel lhe pergunta, aliás, se acredita em almas do outro mundo, ele é indiferente, ao que aquele reage dizendo no tom que lhe é típico - “E por que é que não há de crer, seu burro?" (ASSIS, 2008, p. 493).

Por fim, Procópio incita o leitor a também lhe pagar com honrarias fúnebres, como ele mesmo havia feito com o coronel. O detalhe é que quer como lápide um versículo do sermão da montanha alterado: "Bem-aventurados os que possuem, porque eles serão consolados". Vimos na análise de "Uma senhora" diversos momentos de modificações desse sermão por referência a discussões éticas na obra machadiana. Nesse caso, o versículo de Procópio faz referência às bensaventuranças que consolam os "humildes de espírito" e os injustiçados: 
3 Bem-aventurados os humildes de espírito, porque deles é o reino dos céus;

4 Bem-aventurados os que choram, porque eles serão consolados;

5 Bem-aventurados os mansos, porque herdarão a terra;

6 Bem-aventurados os que têm fome e sede de justiça, porque eles serão fartos (BÍBLIA, 1988, p. 8).

Assim, a ironia de Procópio dá indícios de uma leitura recôndita e possível no conto: estar numa posição de privilégio numa sociedade bárbara é a maior motivação do personagem, independentemente do crime. Procópio não acredita em qualquer plano espiritual e num plano material assola o ético. Assim, o sadismo tipificado do coronel parece ser referido mais para as justificações do narrador e para seu prazer oculto, ao ouvir as detrações dos moradores da vila. Lembremos também que, no momento do relato, quem preenche o papel social do antigo paciente é Procópio. Ele agora é quem possui a verve senhoril.

Por um lado, na fala ao leitor suposto, que poderá manter ou não a história para a posteridade, ecoa o horror do ocorrido e a presença da autoanálise, numa espécie de expiação da culpa. Por outro lado, ecoam as relativizações abertas em razão da herança, como se qualquer concessão fosse válida, a partir do momento em que possuir é o maior consolo.

Como citado acima, os indícios estão presentes na narrativa, mas será papel do leitor decidir qual motivação pesa mais. Similarmente ao narrador de Dom Casmurro, Procópio quer-nos convencer de sua versão da história, que choca pelo tema. No entanto, também percebemos o grande comprometimento deste narrador enfermo ${ }^{68}$.

\footnotetext{
${ }^{68}$ A Profa. Dra. Cleusa Rios P. Passos sugeriu no Exame de Qualificação a imagem de Procópio como "enfermeiro enfermo". Informação verbal dada na Faculdade de Filosofia, Letras e Ciências Humanas da Universidade de São Paulo, em 2012.
} 


\section{Considerações finais}

A presente dissertação analisou contos de Machado de Assis, discutindo a questão moral e questões relativas à constituição do sujeito, para alcançar uma leitura mais aprofundada das narrativas curtas selecionadas.

A primeira parte do trabalho deteve-se, em especial, sobre o que seria a questão moral machadiana, a partir de textos críticos do próprio autor. Há textos que constituem marcos da questão moral enquanto problema abordado por Machado. Entre esses textos, podemos mencionar seu primeiro romance, Ressurreição (1872), e artigos críticos da década de 1870. A crítica a O Primo Basílio (1878), por exemplo, assinala um momento de culminância quanto à discussão da questão moral, causando polêmicas que, inclusive, resvalaram para outras áreas.

Também na primeira parte da dissertação, abordaram-se noções relevantes para pensar a composição dos personagens machadianos como, por exemplo, o costume do caráter, a arte do retrato e a figuração de personagens complexos.

O modo de composição dos personagens, em Machado de Assis, possui ligação com a questão moral. No caso da prática do caráter e do retrato, que o autor muitas vezes desenvolveu, parte-se necessariamente de traços morais, típicos ou individuais, para a figuração de um desenho verbal de perfis.

No entanto, no caso de personagens complexos, percebemos, com recorrência, a limitação que as classificações estanques representam. Os personagens complexos machadianos direcionam-se à individualização, à figuração do particular e do diferencial. Na medida em que a formação da subjetividade está relacionada a escolhas morais, podemos afirmar, igualmente, que os personagens complexos machadianos tangenciam a questão moral.

No comentário à questão moral, devemos ter em mente, em especial, a referência a críticos como Augusto Meyer, Alfredo Bosi, Ivan Teixeira, José Luiz Passos e Pedro Meira Monteiro. A maior parte deles dedicou-se a abordar a ficção machadiana, levando em consideração a presença do comportamento humano como um de seus temas relevantes. Ivan Teixeira não abordou a questão da mesma forma. No entanto, ele defendeu a hipótese da presença do 
costume retórico dos caracteres como uma das modalidades de desenho moral praticadas por Machado de Assis.

Augusto Meyer, não por coincidência, foi o crítico que, ao mesmo tempo, trouxe a primeiro plano a ligação estreita entre Machado de Assis e os moralistas franceses e abordou a obra machadiana valendo-se de subsídios psicanalíticos. Ensaios de Meyer como "O homem subterrâneo", "Flora", "O espelho" e "Da sensualidade", em especial, demonstram a preocupação ora com "o monstro cerebral" (MEYER, 2008, p. 19), o analista implacável, ora com a formação de personagens evanescentes e a narração reticente do desejo, em Machado de Assis.

Ao citar o medalhonismo de Machado e de outras figuras da tradição literária, Meyer defende, por exemplo, que se deve perscrutar "o reverso da medalha" (MEYER, 2008, p. 98). Herdeiro da interpretação pessimista de Machado de Assis desenvolvida por Alcides Maya em 1912, que enfoca o humour, Meyer vai além e levanta problemas relacionados à sombra do autor. Ou seja, Meyer perscrutou o lado "interior", não oficial e não evidente de Machado de Assis $^{69}$. Trata-se de uma leitura a contrapelo, poética e, entre outros aspectos, tributária do ideário psicanalítico.

Por fim, ainda na primeira parte da dissertação, comentei "O espelho", de Papéis avulsos, enquanto obra de Machado de Assis que é paradigmática em relação aos temas da questão moral e de processos de subjetivação figurados literariamente. Jacobina é caracterizado como tipo no conto. No entanto, o mesmo personagem demonstra anseios de indivíduo e pratica a reflexão como forma de autoanálise. Quando se autoanalisa, Jacobina é alçado à condição de personagem complexo porque pode perscrutar suas motivações e seu mundo interno.

O conto "O espelho" é arquitetado de forma dupla. O tema e a história espelham a estrutura narrativa porque falam sobre a teoria da alma humana dupla e sobre a manifestação do duplo enquanto imagem alienada do sujeito. Nos dois níveis - o da estrutura narrativa e o da fábula -, reconhecemos um

\footnotetext{
69 "O Machado interior, desrecalcado e empenhado principalmente em analisar, duvidar, sorrir, tanto que só consegue atingir o tonus da alegria criadora ao defrontar os temas propícios à disjunção e à dúvida, quando muito se ajusta ao Machado exterior, na medida em que viver é necessariamente contradizer-se e para negar será preciso afirmar, ou a destruição postula um principio criador" (MEYER, 2008, p. 99).
} 
dado de cisão e outro de falta. A cisão se dá pela duplicação e pelo descompasso entre as instâncias envolvidas. Jacobina deixa-se capitular pelo seu duplo. Ele defende uma teoria, de forma metódica, mas ela não se sustenta, porque o desejo impõe-se. A falta se mostra porque Jacobina aposta excessivamente nas ilusões do Imaginário, encontrando-se desamparado, quando estas se revelam alienantes e alienadas. No plano da estrutura narrativa, por sua vez, somos capitulados pelo caso contado por Jacobina. No fim, o narrador em primeira pessoa abandona a narrativa bruscamente, então, o leitor é deixado à deriva pela função imaginária que Ihe preenchia a leitura. $\mathrm{O}$ conto acaba por se mostrar como o outro que coloca o leitor em condição alienada.

A fortuna crítica de "O espelho" teve início apenas em 1935, com o ensaio homônimo de Augusto Meyer. Não é por acaso que o ensaio de Meyer comece com a história do próprio crítico enquanto leitor desamparado do conto.

Dessa forma, a leitura crítica de "O espelho" surgiu junto com a etapa psicológica da crítica machadiana e por causa dela. Essa linha crítica é representada exponencialmente por Augusto Meyer e Lucia Miguel Pereira, entre as décadas de 1930 e 1950. Críticas recentes também se lançaram à interpretação machadiana munida da interface com a psicanálise, como ocorre nos ensaios de Cleusa Rios P. Passos e Lucia Serrano Pereira.

Talvez o que mais se destaque nas recepções da crítica psicológica do conto "O espelho" seja a assunção da alteridade como fundamental à constituição do sujeito e à formação do indivíduo. Em "O espelho", ressalta-se a necessidade do olhar da alteridade e do reconhecimento social.

É interessante, aliás, que na análise dos contos selecionados há com frequência a questão do olhar do outro. Isto ocorre nos dois contos da década de 1870. Em "Ponto de vista (Quem desdenha...)", de Histórias da meia-noite, a protagonista Raquel se metamorfoseia e aprende a dissimular, a partir do contato com o olhar da amiga, Luísa. Em "O sainete", os temas da voracidade, da inveja, do ciúme e do olhar encontram-se juntos. Assim, a viúva Seixas apenas se transforma erótica e moralmente, após saber que seu pretendente era visto e admirado por outros.

No conto "D. Benedita (Um retrato)", de Papéis avulsos, o olhar "inquieto, miúdo, repetido, instantâneo" (ASSIS, 2008, p. 288) da personagem 
dá medida de seu desenho problemático. O conto simula a dificuldade de retratar uma senhora do século 19, mas, no fim, parece sugerir ao leitor (e à leitora da revista $A$ Estação) uma espécie de impossibilidade do retrato e da formação da subjetividade.

D. Benedita não se assume como sujeito de desejo, mas de veleidade. Suas linhas mestras não são apreendidas porque são voláteis. No desfecho, 0 conto sai do registro supostamente realista que desenvolvia e passa para uma cena de quimera. A fada Veleidade, que se encontra num quadro, aparece para d. Benedita, revelando-se como a fada que presidira seu nascimento. $O$ retrato desemboca no caráter da veleidade. No entanto, esse caráter é nenhum, dado que evanescente.

Em "Galeria Póstuma", encontramos uma galeria de retratos negativos e um autor ficcional que se constitui segundo o ponto de vista da morte. Joaquim Fidélis é um retratista exímio, mas a franqueza com que desenha os caracteres de sua parentela é insustentável dentro do funcionamento das relações sociais. O sobrinho Benjamin é o único que tem acesso à escrita do tio que despreza os familiares. Ele também é o único que pode ver a expressão do cadáver com "um leve arregaço irônico ao canto esquerdo da boca" (ASSIS, 2008, p. 372), formando uma máscara original, que logo se prega à persona do autor defunto. Em pouco tempo, a máscara do autor do manuscrito oblitera em Benjamin a memória do tio vivo.

O ponto mais interessante de "Galeria póstuma" talvez seja a mirada que Benjamin realiza de seu próprio retrato. O personagem desemboca, então, num impasse em relação à sua herança simbólica. Benjamin dá início à experiência de descentramento quanto ao imaginário da figura paterna. Nesse sentido, esse conto de Histórias sem data suscita novamente o processo pelo qual o sujeito passa, ao ver sua própria imagem, de forma alienada. Consequentemente entra em pauta a dependência do olhar de terceiros. Por fim, as atitudes de Benjamin condizem ironicamente com seu retrato e ele aprende a dissimulação, prática que faz parte da herança que o finado the passara.

Em "Uma senhora", conto que também pertence à coletânea Histórias sem data, a relação intersubjetiva inclina-se para a questão moral. Assim, o desdobramento e a perscrutação das intenções da personagem passam a 
primeiro plano. Tanto que uma das últimas frases do narrador sobre a senhora debate intenções: "Que tal fosse a intenção de d. Camila não o juro eu" (ASSIS, 2008, p. 402).

D. Camila tem como mola de sua motivação o desejo irrealizável de não envelhecer. Dessa forma, o modo como a personagem lida com os outros pauta-se por dissimulação e racionalizações, que são cobertas de véus de diversas tonalidades como "orgulho" e "amor materno", por exemplo. 0 narrador do conto constrói e desvela as intenções da personagem, mas não jura. Assim, o leitor encontra-se novamente à deriva, diante do texto. Dessa vez, contudo, ele se encontra diante de um dilema insolúvel que está implicado na leitura.

Em "O enfermeiro", de Várias histórias, problema semelhante ocorre. No entanto, o dilema ético que é passado às mãos do leitor é potencializado pelo fato de o narrador do conto ser um senhor na primeira pessoa que nos interpela, de forma persuasiva. O dilema ronda as circunstâncias de um crime. A moral está expressivamente implicada. O foco narrativo de Procópio leva-nos a suspeita semelhante à que se desenvolve na leitura de Dom Casmurro. Questões identitárias do narrador-personagem também são desenvolvidas. Afinal, Procópio é um assassino, um proprietário ou um velho enfermo? É possível que todas as opções estejam corretas.

Nesses contos da obra machadiana, o autor implícito ou o narrador orquestrará o desenvolvimento de facetas múltiplas dos personagens sob facetas aparentes, insinuando-as, sem revelá-las por completo. O remate penoso do passo interpretativo é deixado para o leitor. Com frequência, os leitores são convocados a interpretar personagens, inclusive de forma ética. Contudo, uma escolha interpretativa elimina ambiguidades do texto, e o trabalho de interpretação permanece ironicamente inconcluso diante de um texto pulsante.

Apesar dessa consideração final, creio que podemos, ao menos, perceber que há vários tipos de descentramento operados pela obra de Machado de Assis. Os tipos de descentramento que procurei aqui abordar tangenciam, sobretudo, questionamentos em torno da representação literária, da composição de personagens, de seus processos de subjetivação e de suas subjetividade. 


\section{Referências Bibliográficas}

\section{Obras Literárias}

ASSIS, Machado de. Obra completa em quatro volumes. Rio de Janeiro: Nova Aguilar, 2008.

- Falenas. Rio de Janeiro: B. L. Garnier, 1870. Disponível em: http://www.brasiliana.usp.br/bbd/handle/1918/00210100. Acesso em: $01 / 03 / 2013$ . Histórias da meia-noite. São Paulo: Martins Fontes, 2007. . Papéis avulsos. São Paulo: Martins Fontes, 2005.

DIAS, Gonçalves. Últimos cantos: poesias. Rio de Janeiro: Typographia de F. de Paula $1851 . \quad$ Dito, Disponível em: http://www.brasiliana.usp.br/bbd/handle/1918/00634600. Acesso em: 25/02/2013.

GOETHE, Johan Wolfgang Von. The German Refugees. Sawtry: Dedalus, 2006.

GOGOL, Nicolai. O capote. Porto Alegre: L\&PM, 2000.

LONGFELLOW, Henry Wadsworth. Selected poems. New York: Gramercy Books, 1992.

MALHADAS, Daisi. Teofrasto: os caracteres. São Paulo: E.P.U., 1978.

NASSAR, Raduan. Menina a caminho. São Paulo: Companhia das Letras, 1997.

PERRAULT, Charles. Contos e fábulas. São Paulo: Iluminuras, 2007. 
POE, Edgar Allan. Histórias extraordinárias. São Paulo: Abril Cultural, 1978.

SHAKESPEARE, William. Otelo. Porto Alegre: L\&PM, 2012.

\section{Obras e Sites de Referência}

AZEVEDO, Sebastião Laércio. Dicionário de nomes de pessoas. Rio de Janeiro: Civilização Brasileira, 1993.

IDICIONÁRIO AULETE. Disponível em: http://aulete.uol.com.br/index.php. Acesso em: 10/08/2013.

JOBIM, José Luis Jobim (org.), MASSA, Jean-Michel et al. A biblioteca de Machado de Assis. Rio de Janeiro: Academia Brasileira de Letras, Topbooks, 2001.

MACHADODEASSIS.NET. Rio de Janeiro: CNPq, FAPERJ, Casa de Rui Barbosa. Disponível em: http://www.machadodeassis.net/. Acesso em: 10/08/2013.

MACHADO, Ubiratan (org.). Bibliografia machadiana: 1959-2003. São Paulo: Edusp, 2005.

MOREIRA, Celuta Gomes. O conto brasileiro e sua crítica, bibliografia (19411974). Rio de Janeiro: Biblioteca nacional, 1974.

SOUSA, J. Galante de. Fontes para o estudo de Machado de Assis. Rio de Janeiro: Instituto Nacional do Livro, 1958.

\section{Crítica e Teoria Literária}

Ab'SABER, Tales A. M. "Dois mestres: crítica e psicanálise em Machado de Assis". In: CEVASCO, Maria; OHATA, Milton (org.). Um crítico na periferia do capitalismo. São Paulo: Companhia das Letras, 2007. 
BAPTISTA, Abel Barros. "O legado Caldwell ou o paradigma do pé atrás". In: Portuguese studies, v. 1. Califórnia, Santa Barbara: 1994.

BELLEMIN-NOËL, Jean. Psicanálise e literatura. São Paulo: Editora Cultrix, 1978.

BONOMO, Daniel Reizinger. "Superfície especular, texto especulativo: Machado de Assis e uma leitura do conto o espelho". In: XI Congresso Internacional da ABRALIC, 2008, São Paulo. Tessituras, interações, convergências, 2008.

BOSI, Alfredo. Brás Cubas em três versões: estudos machadianos. São Paulo: Companhia das Letras, 2006. . O enigma do olhar. São Paulo: Martins Fontes, 2007.

CADERNOS DE LITERATURA BRASILEIRA, n. 23 e 24. São Paulo: Instituto Moreira Salles, 2008.

CANDIDO, Antonio. "Esquema de Machado de Assis". In: Vários Escritos. Rio de Janeiro: Ouro sobre Azul; São Paulo: Duas Cidades, 2004.

CARPEAUX, Otto Maria. "Apresentação". In: ASSIS, Machado de. Contos A. Rio de Janeiro: Lia Editor, s.d.

CARROLL, Noël. A filosofia do horror ou paradoxos do coração. São Paulo: Papirus, 2000.

D'ONOFRIO, Salvatore. "A ironia do destino no conto machadiano". In: et al. Conto brasileiro: quatro leituras. Petrópolis: Editora Vozes, 1979.

FREYRE, Gilberto. Sobrados e mucambos, decadência do patriarcado rural e desenvolvimento do urbano. São Paulo: Record, 2000. 
GLEDSON, John. "A história do Brasil em Papéis avulsos de Machado de Assis". In: CHALOUB, S.; PEREIRA, A. M. (Org.). A história contada: capítulo de história social da literatura no Brasil. Rio de Janeiro: Nova Fronteira, 1998. . "Translator's Introduction". In: ASSIS, Machado de. A chapter of hats: selected stories. London: Bloomsburry, 2008.

GODOI, Rodrigo Camargo de. '“Altamente literário' e o 'altamente moral': Machado de Assis e o Conservatório Dramático Brasileiro (1859-1864)". In: Olho d'água Revista do Programa de Pós-Graduação em Letras da UNESP. São José do Rio Preto, 1(2): 2009.

GOTLIB, Nádia Battella. Teoria do conto. São Paulo: Editora Ática, 1988.

GUIMARÃES, Hélio de Seixas. Os leitores de Machado de Assis: o romance machadiano e o público de literatura no século 19. São Paulo: Nankin, Editora da Universidade de São Paulo, 2004.

HERNANDEZ, Ascensión Rivas (coord). Un clásico fuera de casa: nuevas miradas sobre Machado de Assis. Recife: Editora Massangana; Salamanca: Centro de estudos brasileños de La Universidad de Salamanca, 2010.

JOBIM, José Luís. "Machado de Assis: o crítico como romancista". In: Machado de Assis em linha, ano 3, número 5. Rio de Janeiro: Fundação Casa de Rui Barbosa, junho de 2010.2 Disponível em: http://machadodeassis.net/revista/numero05/rev num05 artigo07.asp Acesso em: 18/06/12.

MACHADO, Ubiratan (Org.). Machado de Assis: Roteiro da consagração. Rio de Janeiro: EDUERJ, 2003.

MAY, Charles E. Short story theories. Ohio: Ohio University Press, 1976.

MAYA, Alcides. Machado de Assis (algumas notas sobre o humour). Rio de Janeiro: Livraria Edithora Jacinto Silva, 1912. 
MEYER, Augusto. Machado de Assis (1935-1958). Rio de Janeiro: José Olympio: ABL, 2008.

. "De Machadinho a Brás Cubas". In: Revista do livro, ano III, n. 11, setembro, 1958.

MONTEIRO, Pedro Meira. "Falo das linhas vistas: um esboço sobre a arte do retrato no Memorial de Aires". Machado de Assis em linha, ano 3, número 6. Rio de Janeiro: Fundação Casa de Rui Barbosa, dezembro de 2010. Disponível em: $\quad$ http://machadodeassis.net/revista/numero06/rev num06 artigo06.pdf. Acesso em: 15/08/2012.

. "Machado de Assis e Pascal: um contraponto". In: GUIMARÃES, Hélio de Seixas, SENNA, Marta de (Org.). Machado de Assis e o outro: diálogos possíveis. Rio de Janeiro: Móbile, 2012.

. "Mesa-redonda com participações de Hélio Seixas Guimarães, Ivan Marques, Juracy Assmann Saraiva e Pedro Meira Monteiro". In: Machado de Assis em linha: revista eletrônica de estudos machadianos. Fundação Casa de Rui Barbosa. Ano 1, número 4, dezembro de 2009. Disponível em: http://machadodeassis.net/revista/numero04/rev num04 artigo04.asp. Acesso em: 13/08/2012.

PASSOS, Cleusa Rios P. As armadilhas do saber. São Paulo: Editora da Universidade de São Paulo, 2009.

PASSOS, José Luiz. Machado de Assis: o romance com pessoas. São Paulo: Editora da Universidade de São Paulo, Nankin, 2007.

PASTA JR., José Antonio. "Le point de vue de la mort (une structure récurrante de la culture brésilienne)". In: Voies du paysage: réprésentations du monde Iusophone. Cahier. Centre de Recherche sur les Pays Lusophones, v. 14, Paris, 2007.

. "Singularidade do duplo no Brasil". In: A clínica do especular na obra de Machado de Assis. Paris: Association Lacanienne internationale, 2005. 
"Variação machadiana sobre o tema da formação". In: PERES, D. T.:

MATTOS, F. C.; REPA, L.; NOBRE, M.; KEINERT, M. C.; MELO, R. S. Tensões e passagens: filosofia, crítica e modernidade. São Paulo: Singular/Esfera Pública, 2008.

PEREIRA, Lúcia Miguel. Machado de Assis: estudo crítico e biográfico. Belo Horizonte: Itatiaia; São Paulo: Editora da Universidade de São Paulo, 2004. Prosa de ficção (de 1870 a 1920): história da literatura brasileira. Belo Horizonte, São Paulo: Editora Itatiaia, Editora da Universidade de São Paulo, 1988.

PEREIRA, Lucia Serrano. Um narrador incerto, entre o estranho e o familiar - a ficção machadiana na psicanálise. Rio de Janeiro: Cia. de Freud, 2004.

. O conto machadiano, uma experiência de vertigem: ficção e psicanálise. Rio de Janeiro: Cia. de Freud, 2008.

PEREIRA, Mário Eduardo Costa. "Solidão e alteridade em A hora da estrela, de Clarice Lispector". In: (Org.) Leituras de Psicanálise Estéticas da exclusão. Campinas, SP: ALB e Mercado de Letras, 1998.

PIGLIA, Ricardo. Formas breves. São Paulo: Cia. das Letras, 2004.

POE, Edgar Allan. "A Filosofia da composição". In: BARROSO, Ivo (Org.). O corvo e suas traduções. Rio de Janeiro: Lacerda Editora, 2000.

PUJOL, Alfredo. Curso literário em sete conferências na Sociedade de Cultura Artística de São Paulo. São Paulo, Rio de Janeiro: Imprensa Oficial, ABL, 2007.

RIBEIRO, Luis Filipe. "Machado, um contista desconhecido". In: Machado de Assis em linha: revista eletrônica de estudos machadianos. Fundação Casa de Rui Barbosa. Ano 1, número 1, junho de 2008. Disponível em: http://machadodeassis.net/rev num01 artigo02.asp. Acesso em: 18/06/12. 
ROMERO, Sílvio. Machado de Assis: estudo comparativo de literatura brasileira. Campinas: Ed. da Unicamp, 1992.

ROSENFELD, Anatol. "Literatura e personagem". In: A personagem de ficção. São Paulo: Perspectiva, 2004.

SANTIAGO, Silviano. "Retórica da verossimilhança". In: . Uma literatura nos trópicos. Rio de Janeiro, Rocco, 2000.

SCHWARZ, Roberto. "A viravolta machadiana". Novos Estudos - CEBRAP, São Paulo, n.69 (julho, 2004). . Ao vencedor as batatas. São Paulo: Duas Cidades, Ed. 34, 2000. . Um mestre na periferia do capitalismo: Machado de Assis. São Paulo: Duas Cidades, Ed. 34, 2000.

SILVA, Ana Cláudia Suriani da. Machado de Assis's philosopher or dog? From serial to book form. Londres: Modern Humanities Research Association and Maney Publishing, 2010.

TEIXEIRA, Ivan. "Machado de Assis e o costume retórico dos caracteres". In: Revista IEB, n. 50, 2010 set./mar.

Teresa - Revista de Literatura Brasileira. Edição especial sobre Machado de Assis. n. 6-7. São Paulo: Ed. 34, Imprensa Oficial, 2006.

VASCONCELOS, Sandra G. T. "Do outro lado do espelho (Um estudo de E. A. Poe e Machado de Assis). Língua e literatura, v. 15, n. 18, 1990.

\section{Geral}

ALENCASTRO, Luiz Felipe. "Vida privada e ordem privada no Império". In: NOVAIS, Fernando A.; ALENCASTRO, Luiz Felipe (org.). História da vida privada no Brasil, v. 2. São Paulo: Companhia das Letras. 
BÍBLIA Sagrada. Brasília: Sociedade Bíblica do Brasil, 1988.

BIRMAN, Joel. Estilo e modernidade em psicanálise. São Paulo: Ed. 34, 1997.

BRANDÃO, R. A ordem do mundo e do homem: estudos sobre metafísica e moral em Voltaire. 2008. 254 f. Tese (Doutorado em Filosofia), Faculdade de Filosofia Letras e Ciências Humanas, Universidade de São Paulo, São Paulo.

DEBRET, Jean Baptiste. "Planta da cidade de S. Sebastião do Rio de Janeiro". In: Voyage Pittoresque e Historique au Brésil, v. 2. Paris: Firmin Didot Frères, 1835. Disponível em: http://www.brasiliana.usp.br/bbd/handle/1918/624520093. Acesso em: 11/03/13.

FREUD, Sigmund. Além do Princípio de Prazer. Rio de Janeiro: Imago, 2003. . A interpretação dos sonhos. Rio de Janeiro, Imago, 2001. . "A perda da realidade na neurose e na psicose". In: Edição Standard brasileira das obras psicológicas completas de Sigmund Freud, v. XIX. Rio de Janeiro: Imago, 1986.

. "Os chistes e sua relação com o inconsciente". In: Obras psicológicas de Sigmund Freud: edição standard brasileira, v. VIII. Rio de Janeiro, Imago, 1987.

. "O Estranho". In: . Obras psicológicas de Sigmund Freud: edição standard brasileira, v. XVII. Rio de Janeiro: Imago, 1987.

. O mal-estar na civilização. São Paulo: Penguin Classics, Companhia das Letras, 2011.

. Sobre a psicopatologia da vida cotidiana (1901). In: Obras psicológicas de Sigmund Freud: edição standard brasileira, v. VI. Rio de Janeiro, Imago, 2006.

GARCIA-ROZA, Luiz Alfredo. Introdução à metapsicologia freudiana. A interpretação do sonho, v. 2. Rio de Janeiro: Jorge Zahar Editor, 2008.

HEGEL, G. W. F. - Fenomenologia do espírito. Parte I. Tradução Paulo Meneses, colaboração de Karl-Heinz Efken. 2ª Ed. Petrópolis: Vozes, 1992. 
KLEIN, Melanie. "Inveja e gratidão". In: Inveja e gratidão e outros trabalhos (1946-1963). Rio de Janeiro: Imago Editora, 1991.

LA BRUYÈRE, Jean de. Caracteres, v. 1. [Trad.] Luiz Fontoura. Rio de Janeiro: Ed. Athena, 1937.

LACAN, Jacques. O eu na teoria de Freud e na técnica da psicanálise. $O$ Seminário, Livro 2. Rio de Janeiro: Jorge Zahar Editor, 2010.

. "O estádio de espelho como formador da função do eu tal como nos é revelada na experiência psicanalítica". In: Escritos. Trad. Vera Ribeiro. Rio de Janeiro: Jorge Zahar, 1998.

LA ROCHEFOUCAULD, François duc de (1613-1680). Reflexions ou sentences et maximes morales. Paris : Garnier Frères, 1961.

HAAG, Carlos. "Ossos que falam". Pesquisa FAPESP. São Paulo, Dezembro 2011.

Disponível

em:

http://www.revistapesquisa2.fapesp.br/?art=4569\&bd=1\&pg=1. Acesso em: 18/06/12.

RANK, Otto. Don Juan et le double: études psychanalytiques. Paris: Payot, 19?.

ROUSSEAU, Jean-Jacques. Os devaneios do caminhante solitário. Brasília: Editora da Universidade de Brasília, 1986.

SAFATLE, Vladimir. Lacan. São Paulo: Publifolha, 2007.

SCARRY, Elaine. On beauty and being just. Princeton e Oxford: On beauty and being just, 1999.

SCHOPENHAUER, Arthur. O mundo como vontade e representação. Rio de Janeiro: Contraponto, 2004. 
WOLLHEIM, Richard. On the emotions. New Haven; London: Yale University Press, 1999. 